\title{
6. SITE 446, DAITO BASIN, DEEP SEA DRILLING PROJECT LEG 58
}

\author{
The Shipboard Scientific Partyl
}

\begin{abstract}
HOLE 446
Date occupied: 18 January 1978

Date departed: 21 January 1978

Time on hole: $3 \frac{1}{2}$ days

Position (latitude; longitude): $24^{\circ} 42.04^{\prime} \mathrm{N}$; $132^{\circ} 46.49^{\prime} \mathrm{E}$

Water depth (sea level; corrected m, echo sounding): 4952.0

Water depth (rig floor; corrected m, echo sounding): 4962.5

Bottom felt (m, drill pipe): 4980.0

Penetration (m): 420.5

Number of cores: 46

Total length of cored section (m): 420.5

Total core recovered $(\mathrm{m}): 197.10$

Core recovery $(\%): 47$

Oldest sediment cored:

Depth sub-bottom (m): 395.7

Nature: claystone

Age: early Eocene

Measured velocity $(\mathrm{km} / \mathrm{s}): 1.85$

Basement:

Depth sub-bottom (m): 420.5

Nature: basalt

Velocity range $(\mathrm{km} / \mathrm{s}): 4.22-5.38$

Principal Results: Site 446 is in the Daito Basin, south of the Daito Ridge, northwest Philippine Sea. The sedimentary section consists of 14.2 meters of Pliocene terrigenous mud and clay which overlies 158.3 meters of Pliocene, Miocene, Oligocene, and Eocene pelagic clay. Next below is 190.0 meters of Eocene mudstone, claystone, siltstone, and tur-
\end{abstract}

\footnotetext{
1 George deVries Klein (Co-Chief Scientist), Department of Geology, University of Illinois, Urbana, Illinois; Kazuo Kobayashi (CoChief Scientist) Ocean Research Institute, University of Tokyo; Stan M. White, Deep Sea Drilling Project, Scripps Institution of Oceanography, La Jolla, California; Hervé Chamley, Laboratoire de Géologie Marine, Centre d'Océanographie, Centre Universitaire de Luminy, Marseille, France (now at Université de Lille I, Villaneuve d'Ascq, France); Doris Curtis, Bellaire Research Center, Shell Development Company, Houston, Texas; Atsuyuki Mizuno, Geological Survey of Japan, Kawasaki, Japan; Henry Dick, Department of Geology and Geophysics, Woods Hole Oceanographic Institution, Woods Hole, Massachusetts; Gennady V. Nisterenko, Vernadasky Institute of Geochemistry and Analytical Chemistry, USSR Academy of Sciences, Moscow, USSR; Nicholas G. Marsh, Department of Geological Sciences, University of Birmingham, Birmingham, England; Douglas Waples, Chemistry and Geochemistry Department, Colorado School of Mines, Golden, Colorado; Dorothy Jung Echols, Department of Earth and Planetary Sciences, Washington University, St. Louis, Missouri; Hisatake Okada, Department of Geology, Faculty of Science, Yamagata University, Yamagata, Japan; Jon R. Sloan, Department of Geology, University of California, Davis, California; David M. Fountain, Department of Geology, University of Montana, Missoula, Montana; and Hajimu Kinoshita, Department of Earth Sciences, Faculty of Science, Chiba University, Tokyo, Japan.
}

bidite sandstone. Underlying those rocks is a 266.0-meter succession of interlayered calcareous mudstone, siltstone, sandstone, conglomerate, and ash, intruded by 23 postearly Eocene basalt sills.

Shipboard analysis of paleomagnetism shows that Site 446 has migrated from an equatorial latitude over the past $52 \mathrm{~m} . \mathrm{y}$. The age of the basement of the northwest Philippine Sea is possibly as young as early Eocene.

\section{HOLE 446A}

Date occupied: 22 January 1978

Date departed: 26 January 1978

Time on hole: 4 days

Position (latitude; longitude): $24^{\circ} 42.04^{\prime} \mathrm{N} ; 132^{\circ} 46.49^{\prime} \mathrm{E}$

Water depth (sea level; corrected m, echo sounding): 4952.0

Water depth (rig floor; corrected m, echo sounding): 4962.5

Bottom felt (m, drill pipe): 4980.0

Penetration (m): 628.5

Number of cores: 28

Total length of cored section (m): 256.5

Total core recovered $(\mathrm{m}): 117.09$

Core recovery $(\%): 46$

Oldest sediment cored:

Depth sub-bottom (m): 619.0

Nature: claystone

Age: late early Eocene

Measured velocity $(\mathrm{km} / \mathrm{s}): 2.53$

Basement:

Depth sub-bottom (m): 621.0

Nature: basalt sills

Velocity range $(\mathrm{km} / \mathrm{s}): 3.74-5.84$

Principal Results: See Hole 446.

\section{BACKGROUND AND OBJECTIVES}

\section{Background}

The objectives at Site 446 were identical to those at Site 445 . Site 446 is in the triangular part of the northwest Philippine Sea, in an intermediate-sized basin immediately south of the Daito Ridge and north of the Oki-Daito Ridge. The Daito Ridge and Basin province is part of a remnant-arc. This area has been of considerable interest to several workers, and prior study included deep drilling at Site 445 and in the adjoining Kyushu-Palau Ridge at Site 296 (Karig, Ingle, et al., 1975), structural and regional tectonic analysis (Karig, 1975; Hilde et al., 1977; Watts et al., 1977; Mizuno et al., 1975, in press), and dredging of bottom samples (Mizuno et al., 1975, in press; Shiki et al., 1976). Magnetic lineations were identified south of the Daito 
Ridge and Basin province by Louden (1976) and Watts et al. (1977), but none have been identified in the province itself. All available data prior to drilling of Site 445 suggested that the Daito Ridge and Basin is very old, and that in fact this part of the northwest Philippine Sea is underlain by older crust trapped behind the remnant arc of the Daito Ridge and the Oki-Daito Ridge (Karig, 1975; Hilde et al., 1977; Watts et al., 1977; Mizuno et al., 1975, in press). The trapping mechanism should show similarities with the hypothetical origin of the Bering Sea (Cooper et al., 1976).

Drilling at Site 445 did not provide any new insights into these tectonic relations: the site was abandoned because of bad weather. However, shipboard analysis of paleomagnetism indicated that Site 445 migrated from an equatorial latitude to its present position over a period of 48 m.y.

Dredge hauls from the Daito Ridge and Basin, the Oki-Daito Ridge, and the Amami Plateau indicate that the geology of the region is extremely variable. Greenschist, hornblende schist, and serpentine have been collected from the Daito Ridge, indicating some regional metamorphism (Mizuno et al., 1975; Shiki et al., 1976). Igneous rocks recovered from the Daito Ridge include andesite and diorite of island-arc origin. Dredge hauls from the Oki-Daito Ridge recovered basalt. Andesite, granodiorite, and basalt were recovered from the Amami Plateau, Drilling at Site 445 confirmed this variability: middle-Eocene debris-flow conglomerates contain the same variety of pebble clasts as the dredge hauls.

One of the more interesting discoveries prior to Leg 58 was the dredge recovery of limestone specimens containing Nummulites boninensis, an Eocene larger foraminifer of shallow-water origin (Konda et al., 1977). These samples were recovered from the Daito and OkiDaito Ridges and the Amami Plateau from present water depths of 1160 to 2340 meters. Nummulites boninensis was recovered in several conglomerates of debrisflow origin at Site 445, clearly indicating resedimentation from shallow water. This casts some doubt on prior suggestions of large-scale regional subsidence in the region of Daito Ridge and Oki-Daito Ridge (Mizuno et al., 1975, in press), although some subsidence may have occurred. We expected to clarify this problem of regional subsidence from drilling results at Site 446.

Site 446 was located in an intermediate-sized basin between the Daito Ridge and Oki-Daito Ridge, along a seismic profile surveyed by the R/V Kaiyo-Maru (IPODJapan, 1977) (Figure 1). The seismic-reflection profile obtained by the D/V Glomar Challenger is shown in Figure 2.

\section{Objectives}

The primary objectives at Site 446 were fourfold. Of prime importance was to determine the age of the oldest sediment and of the basement, to determine whether this portion of the north Philippine Sea is underlain by old crust trapped behind a remnant arc. A second objective was to determine the nature of the basement and to elucidate its crustal history. A third objective was to determine the subsidence history of the northwest Philippine Sea from sedimentological and paleontological

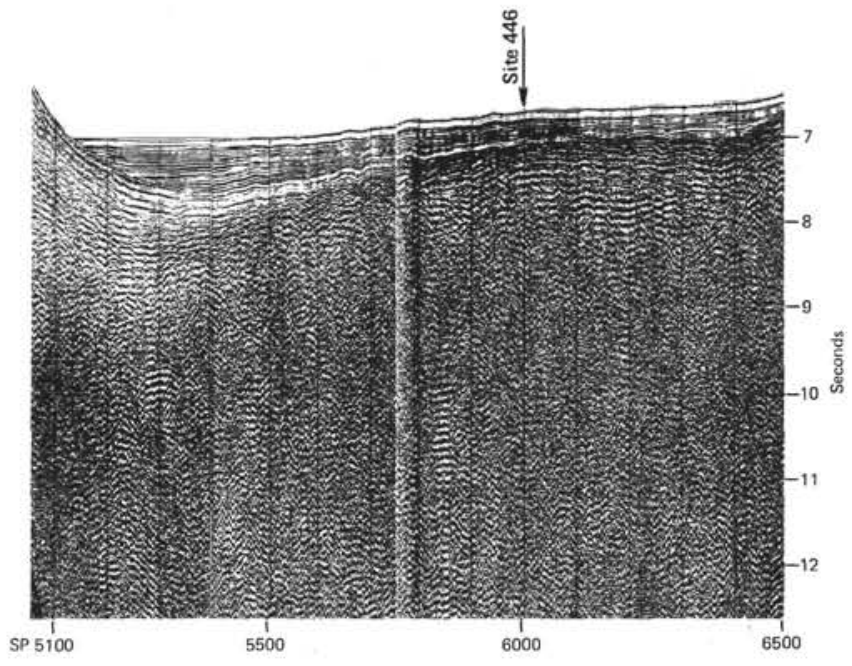

Figure 1. Seismic-reflection profile through Daito Ridge and south of Daito Ridge by $R / V$ Kaiyo-Maru.

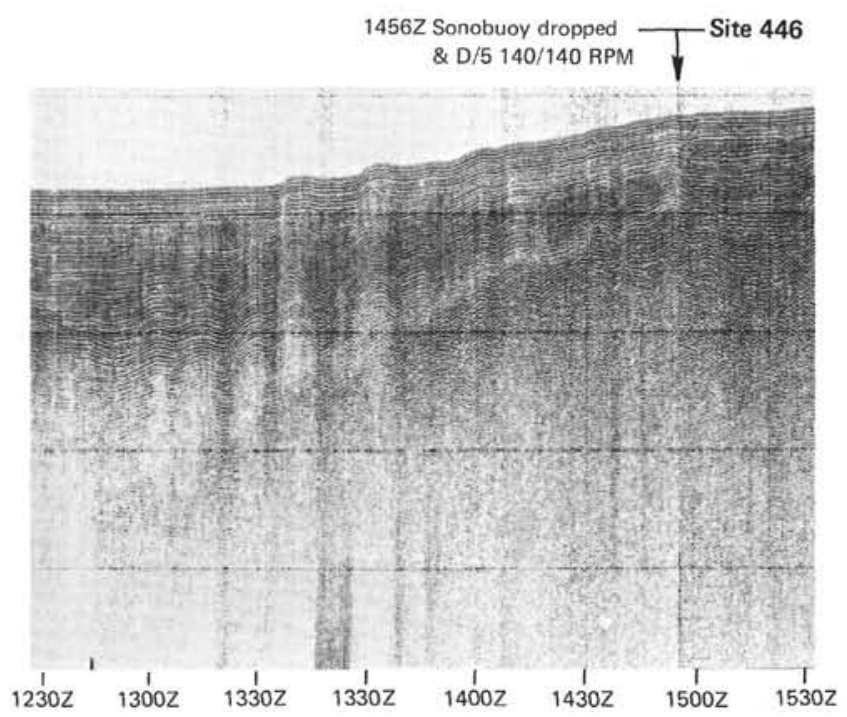

Figure 2. Glomar Challenger seismic-reflection profile approaching Site 446. See Figure 3 for location.

study. Fourth, climatic changes at the site, due to its northward drift over the past $47 \mathrm{~m} . \mathrm{y}$., were to be determined from paleontology and paleomagnetism.

\section{OPERATIONS}

The Challenger left Site 445 at 1530 hours on 17 January. Gear was streamed, and at 1612 hours the Challenger passed over the Site 445 beacon and headed for Site 446 on a course of $206^{\circ}$ (Figure 3).

At 2354 hours, 17 January, after steaming approximately 57 nautical miles, the Site 446 location was reached, and a $16-\mathrm{kHz}$ beacon was dropped. At 0244 hours, 18 January, after a sonobuoy run over the site, gear was pulled in, and at 0336 hours ship's positioning was in the auto mode. RIH for Hole 446 began.

At 1251 hours, 18 January, Hole 446 was spudded in at a water depth of 4980 meters (drill pipe). A program of continuous coring was maintained, and basalt was 


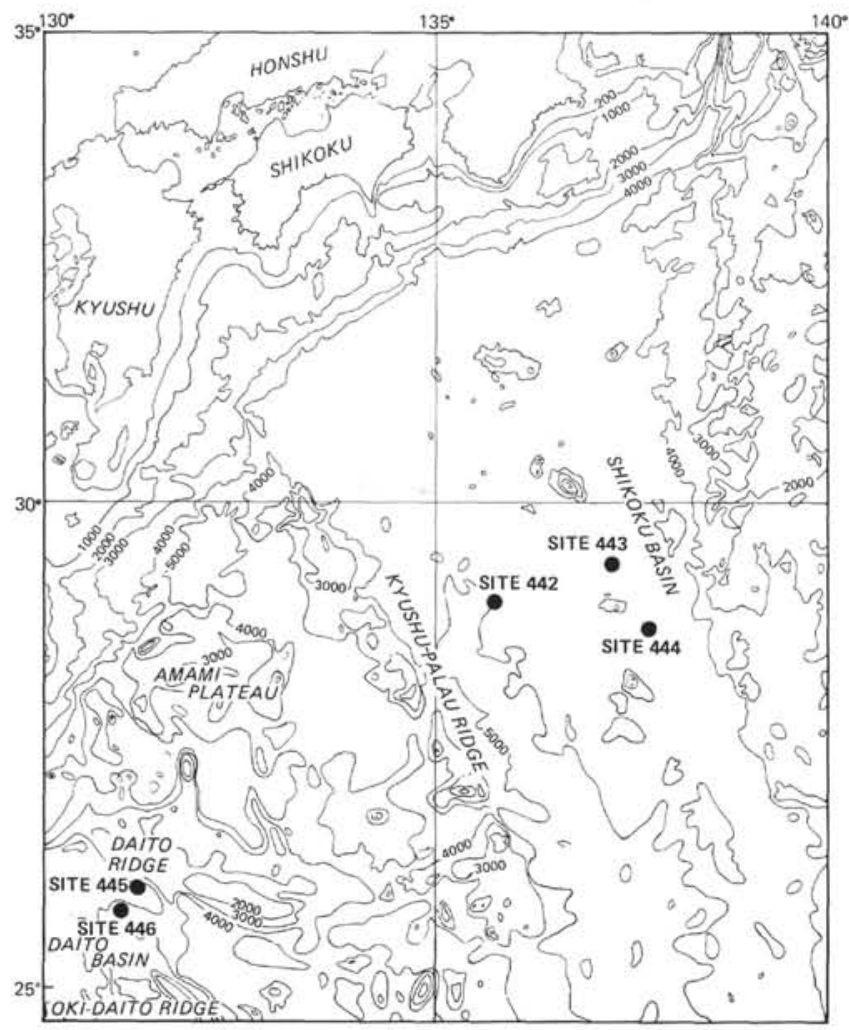

Figure 3. Site location map.

first recovered in Core 41 at a sub-bottom depth of 381 meters (Table 1). Another 0.5 meters of basalt was recovered in the core catcher of Core 42 , an interbed of sediment and basalt being recovered in Core 43 . Cores 44 through 46 were recovered before deteriorating weather conditions on the evening of 21 January forced a decision to pull pipe above the mudline to wait on weather. Total recovery in 46 cores was 197.1 meters of 420.5 meters cored, or 47 per cent. Suspension of operations continued through the morning of 22 January. At 0930 hours, 22 January, weather conditions had moderated and allowed automatic positioning; it was decided to begin lowering pipe to spud Hole 446A. The operational plan for this hole was to drill through the sediment section to just above the first sediment/basalt contact at $\mathbf{3 7 2 . 0}$ meters, and then to core continuously until destruction of the bit.

At 1130 hours, Hole 446A was spudded; it was drilled to 5352.0 meters. The center bit was retrieved, and coring operations resumed, Core 1 being retrieved at 2158 hours, 22 January (Table 1).

Coring continued until 2015 hours on 26 January, when the low recovery and very low core diameter indicated that the bit was exhausted. Bit life was 71.8 hours. In all at Hole 446A, 28 cores were recovered; recovery was 117 meters, or 46 per cent. At 1200 hours on 27 January, pulling of pipe from the hole was completed, including magnafluxing the bottom-hole assembly and Bowen sub.

At 1400 hours, 27 January, gear was streamed for the journey to Naha, Okinawa. After a Williamson turn to pass over the site, the Challenger headed east for a short
TABLE 1

Site 446 Coring Summary

\begin{tabular}{|c|c|c|c|c|c|c|c|}
\hline Cores & $\begin{array}{l}\text { Date } \\
\text { (Jan., } \\
\text { 1978) }\end{array}$ & Time & $\begin{array}{c}\text { Depth From } \\
\text { Drill Floor } \\
\text { (m) } \\
\text { Top Bottom }\end{array}$ & $\begin{array}{l}\text { Depth Below } \\
\text { Sea Floor } \\
\text { (m) } \\
\text { Top Bottom }\end{array}$ & $\begin{array}{l}\text { Length } \\
\text { Cored } \\
\text { (m) }\end{array}$ & $\begin{array}{l}\text { Recovery } \\
\text { (mi) }\end{array}$ & $\begin{array}{c}\text { Recovery } \\
\text { (F) }\end{array}$ \\
\hline $446-1$ & 18 & 1352 & $4980.0-4981.5$ & $0.0-1.5$ & 1.5 & 1.00 & 67 \\
\hline 2 & 18 & 1520 & $4981.5-4991.0$ & $1.5-11.0$ & 9.5 & 0.85 & 9 \\
\hline 3 & 18 & 1636 & $4991.0-5000.5$ & $11.0-20.5$ & 9.5 & 8.56 & 90 \\
\hline 4 & 18 & 1802 & $5000.5-5010.0$ & $20.5-30.0$ & 9.5 & 0.30 & 3 \\
\hline 5 & 18 & 1931 & $5010.0-5019.5$ & $30.0-39.5$ & 9.5 & 8.72 & 92 \\
\hline 6 & 18 & 2042 & $5019.5-5029.0$ & $39.5-49.0$ & 9.5 & 6.67 & 70 \\
\hline 7 & 18 & 2200 & $5029.0-5038.5$ & $49.0-58.5$ & 9.5 & 9.60 & 101 \\
\hline 8 & 18 & 2327 & $5038.5-5048.0$ & $58.5-68.0$ & 9.5 & 7.22 & 78 \\
\hline 9 & 19 & 0044 & $5048.0-5057.5$ & $68.0-77.5$ & 9.5 & 7.17 & 75 \\
\hline 10 & 19 & 0210 & $5057.5-5067.0$ & $77.5-87.0$ & 9.5 & 8.24 & 86 \\
\hline 11 & 19 & 0326 & $5067.0-5076.5$ & $87.0-96.5$ & 9.5 & 5.36 & 56 \\
\hline 12 & 19 & 0450 & $5076.5-5086.0$ & $96.5-106.0$ & 9.5 & 5.35 & 56 \\
\hline 13 & 19 & 0608 & $5086.0-5095.5$ & $106.0-115.5$ & 9.5 & 6.47 & 68 \\
\hline 14 & 19 & 0724 & $5095.5-5105.0$ & $115.5-125.0$ & 9.5 & 7.09 & 75 \\
\hline 15 & 19 & 0846 & $5105.0-5114.5$ & $125.0-134.5$ & 9.5 & 4.65 & 49 \\
\hline 16 & 19 & 1012 & $5114.5-5124.0$ & $134.5-144.0$ & 9.5 & 5.65 & 59 \\
\hline 17 & 19 & 1148 & $5124.0-5133.5$ & $144.0-153.5$ & 9.5 & 0.72 & 8 \\
\hline 18 & 19 & 1321 & $5133.5-5143.0$ & $153.5-163.0$ & 9.5 & 1.60 & 17 \\
\hline 19 & 19 & 1448 & $5143.0-5152.5$ & $163.0-172.5$ & 9.5 & 0.55 & 6 \\
\hline 20 & 19 & 1610 & $5152.5-5162.0$ & $172.5-182.0$ & 9.5 & 1.50 & 16 \\
\hline 21 & 19 & 1730 & $5162.0-5171.5$ & $182.0-191.5$ & 9.5 & 3.14 & 33 \\
\hline 22 & 19 & 1850 & $5171.5-5181.0$ & $191.5-201.0$ & 9.5 & 0.00 & 0 \\
\hline 23 & 19 & 2025 & $5181.0-5190.5$ & $201.0-210.5$ & 9.5 & 3.30 & 35 \\
\hline 24 & 19 & 2153 & $5190.5-5200.0$ & $210.5-220.0$ & 9.5 & 5.74 & 60 \\
\hline 25 & 19 & 2332 & $5200.0-5209.5$ & $220.0-229.5$ & 9.5 & 4.83 & 51 \\
\hline 26 & 20 & 0116 & $5209.5-5219.0$ & $229.5-239.0$ & 9.5 & 5.07 & 53 \\
\hline 27 & 20 & 0239 & $5219.0-5228.5$ & $239.0-248.5$ & 9.5 & 3.78 & 40 \\
\hline 28 & 20 & 0400 & $5228.5-5238.0$ & $248.5-258.0$ & 9.5 & 0.97 & 10 \\
\hline 29 & 20 & 0525 & $5238.0-5247.5$ & $258.0-267.5$ & 9.5 & 2.98 & $3 \mathrm{i}$ \\
\hline 30 & 20 & 0647 & $5247.5-5257.0$ & $267.5-277.0$ & 9.5 & 8.13 & 86 \\
\hline 31 & 20 & 0815 & $5257.0-5266.5$ & $277.0-286.5$ & 9.5 & 4.57 & 48 \\
\hline 32 & 20 & 0941 & $5266.5-5276.0$ & $286.5-296.0$ & 9.5 & 7.72 & 81 \\
\hline 33 & 20 & 1112 & $5276.0-5285.5$ & $296.0-305.5$ & 9.5 & 2.93 & 31 \\
\hline 34 & 20 & 1243 & $5285.5-5295.0$ & $305.5-315.0$ & 9.5 & 8.67 & 91 \\
\hline 35 & 20 & 1423 & $5295.0-5304.5$ & $315.0-324.5$ & 9.5 & 0.20 & 2 \\
\hline 36 & 20 & 1558 & $5304.5-5314.0$ & $324.5-334.0$ & 9.5 & 6.49 & 68 \\
\hline 37 & 20 & 1746 & $5314.0-5323.5$ & $334.0-343.5$ & 9.5 & 0.90 & 9 \\
\hline 38 & 20 & 1935 & $5323.5-5333.0$ & $343.5-353.0$ & 9.5 & 8.95 & 94 \\
\hline 39 & 20 & 2118 & $5333.0-5342.5$ & $353.0-362.5$ & 9.5 & 3.90 & 41 \\
\hline 40 & 20 & 2301 & $5342.5-5352.0$ & $362.5-372.0$ & 9.5 & 2.42 & 25 \\
\hline 41 & 21 & 0053 & $5352.0-5361.5$ & $372.0-381.5$ & 9.5 & 4.51 & 47 \\
\hline 42 & 21 & 0234 & $5361.5-5371.0$ & $381.5-391.0$ & 9.5 & 0.19 & 2 \\
\hline 43 & 21 & 0448 & $5371.0-5380.5$ & $391.0-400.5$ & 9.5 & 5.21 & 55 \\
\hline 44 & 21 & 1014 & $5380.5-5390.0$ & $400.5-410.0$ & 9.5 & 4.50 & 47 \\
\hline 45 & 21 & 1528 & $5390.0-5399.5$ & $410.0-419.5$ & 9.5 & 0.05 & 1 \\
\hline \multirow[t]{2}{*}{46} & 21 & 2205 & $5399.5-5400.5$ & $419.5-420.5$ & 1.0 & 0.68 & 68 \\
\hline & & & & Totals & 420.5 & 197.10 & 47 \\
\hline $446 \mathrm{~A}-1$ & 22 & 2158 & $5352.0-5361.5$ & $372.0-381.5$ & 9.5 & 3.73 & 39 \\
\hline 2 & 22 & 2340 & $5361.5-5371.0$ & $381.5-391.0$ & 9.5 & 2.41 & 25 \\
\hline 3 & 23 & 0221 & $5371.0-5380.5$ & $391.0-400.5$ & 9.5 & 3.57 & 38 \\
\hline 4 & 23 & 0655 & $5380.5-5385.5$ & $400.5-405.5$ & 5.0 & 3.36 & 67 \\
\hline 5 & 23 & 1046 & $5385.5-5390.0$ & $405.5-410.0$ & 4.5 & 2.90 & 64 \\
\hline 6 & 23 & 1432 & $5390.0-5399.5$ & $410.0-419.5$ & 9.5 & 4.35 & 46 \\
\hline 7 & 23 & 1844 & $5399.5-5409.0$ & $419.5-429.0$ & 9.5 & 5.66 & 60 \\
\hline 8 & 23 & 2148 & $5409.0-5418.5$ & $429.0-438.5$ & 9.5 & 2.58 & 27 \\
\hline 9 & 24 & 0133 & $5418.5-5428.0$ & $438.5-448.0$ & 9.5 & 3.51 & 37 \\
\hline 10 & 24 & 0309 & $5428.0-5437.5$ & $448.0-457.5$ & 9.5 & 6.99 & 74 \\
\hline 11 & 24 & 0519 & $5437.5-5447.0$ & $457.5-467.0$ & 9.5 & 2.56 & 27 \\
\hline 12 & 24 & 0835 & $5447.0-5456.5$ & $467.0-476.5$ & 9.5 & 4.82 & 51 \\
\hline 13 & 24 & 1121 & $5456.5-5466.0$ & $476.5-486.0$ & 9.5 & 3.18 & 33 \\
\hline 14 & 24 & 1512 & $5466.0-5475.5$ & $486.0-495.5$ & 9.5 & 3.23 & 34 \\
\hline 15 & 24 & 2009 & $5475.5-5485.0$ & $495.5-505.0$ & 9.5 & 4.72 & 50 \\
\hline 16 & 24 & 2318 & $5485.0-5494.5$ & $505.0-514.5$ & 9.5 & 5.10 & 54 \\
\hline 17 & 25 & 0114 & $5494.5-5504.0$ & $514.5-524.0$ & 9.5 & 3.99 & 42 \\
\hline 18 & 25 & 0330 & $5504.0-5513.5$ & $424.0-533.5$ & 9.5 & 4.48 & 47 \\
\hline 19 & 25 & 0620 & $5513.5-5523.0$ & $533.5-543.0$ & 9.5 & 3.77 & 40 \\
\hline 20 & 25 & 1016 & $5523.0-5532.5$ & $543.0-552.5$ & 9.5 & 4.48 & 47 \\
\hline 21 & 25 & 1507 & $5532.5-5542.0$ & $552.5-562.0$ & 9.5 & 7.44 & 78 \\
\hline 22 & 25 & 1858 & $5542.0-5551.5$ & $562.0-571.5$ & 9.5 & 4.89 & 51 \\
\hline 23 & 26 & 0103 & $5551.5-5561,0$ & $571.5-581.0$ & 9.5 & 7.73 & 81 \\
\hline 24 & 26 & 0528 & $5561.0-5570.5$ & $581.0-590.5$ & 9.5 & 4.47 & 47 \\
\hline 25 & 26 & 0853 & $5570.5-5580.0$ & $590.5-600.0$ & 9.5 & 5.04 & 53 \\
\hline & & & $5580.0-5589.5$ & $600.0-609.5$ & 9.5 & 4.16 & 44 \\
\hline 27 & 26 & 1538 & $5589.5-5599.0$ & $609.5-619.0$ & 9.5 & 2.21 & 23 \\
\hline \multirow[t]{2}{*}{28} & 26 & 1942 & $5599.0-5608.5$ & $619.0-628.5$ & 9.5 & 1.76 & 19 \\
\hline & & & & Totals & 256.5 & 117.09 & 46 \\
\hline
\end{tabular}


seismic survey of the area before turning west for Okinawa. ETA for Okinawa was 0800 hours 30 January,

\section{SEDIMENT LITHOLOGY}

\section{Hole 446}

The stratigraphic sequence is presented in Table 2, Figure 4 . The sediments ranged in age from late Pliocene to late early Eocene; no Quaternary sediments were recovered.

\section{Unit I}

Unit I consists of brown terrigenous (hemipelagic) intermixed mud and clay. It contains 10 to 20 per cent siltsized particles and is composed of clay minerals (72$89 \%)$, quartz and feldspar $(5-10 \%)$, mica $(1-5 \%)$, heavy minerals (augite and hornblende; $1-2 \%$ ), opaque minerals (1-3\%), and a trace of volcanic glass. Pumice fragments and ashy zones are present. The unit is devoid of visible sedimentary structures.

\section{Unit II}

Unit II is distinguished by a change from terrigenous to pelagic sedimentation. It is a distinctive, dark-brown to very dark-grayish-brown pelagic clay and claystone with scattered zones and patches of yellowish-brown clay. The sediment generally has less than 5 per cent silt- sized particles, and 95 per cent or more clay-sized particles. Major mineralogic components include zeolites (commonly $1-5 \%$, but as high as $35 \%$ ), micronodules and opaque minerals (commonly $1-10 \%$, but as high as $20 \%$ ), and clay minerals $(40-96 \%)$. Small amounts of quartz, feldspar, volcanic glass, and carbonate are present. The unit is devoid of visible sedimentary structures. Variations in the general lithology occur, but do not warrant subdivision of the unit. These variations include siliceous-fossil zones (radiolarians and sponge spicules) in Cores 9 and 17; nannofossil ooze in Core 14; a variable zeolite content in Cores 10,11 , and 12 ; chert in Cores 17 and 18; and a variable content of volcanic glass in the sediments.

\section{Unit III}

Unit III is marked by a change from dark browns to greenish grays, and from pelagic to turbiditic and hemipelagic sedimentation. We distinguished two sub-units: sub-unit IIIa, greenish-gray, silty to sandy mudstones and mudstones as turbidites; and subunit IIIb, brownish- to greenish-gray, calcareous mudstones and claystones.

Between unit II in Core 19-1 and unit III in Core $19, \mathrm{CC}$, the lithology changes from brown, zeolitic pelagic clay to greenish-gray terrigenous mudstone in turbidite sequences. Greenish-gray and dark-greenish-gray, glauconitic mudstone forms the major portion of the

TABLE 2

Stratigraphy of Site 446

\begin{tabular}{|c|c|c|c|c|c|}
\hline $\begin{array}{l}\text { Lithologic } \\
\text { Unit }\end{array}$ & $\begin{array}{l}\text { Sub-Bottom } \\
\text { Depth } \\
\text { (m) }\end{array}$ & Core & $\begin{array}{c}\text { Thickness } \\
\text { (m) }\end{array}$ & Characteristics & Age \\
\hline I & $0-14.2$ & $\begin{array}{l}446-1 \text { to } \\
446-3-3 \\
20 \mathrm{~cm}\end{array}$ & 14.2 & Brown (10YR4/3), terrigenous mud, clay & Pliocene \\
\hline II & $14.2-172.5$ & $\begin{array}{l}446-3-3 \\
20 \mathrm{~cm} \text { to } \\
446-19, \mathrm{CC}\end{array}$ & 158.3 & $\begin{array}{l}\text { Dark-brown (10YR } 3 / 3) \text {, very dark- } \\
\text { grayish-brown }(10 \mathrm{YR} 3 / 2) \text {, pelagic clay } \\
\text { with ash, siliceous fossils, variable zeolite } \\
\text { content. }\end{array}$ & $\begin{array}{l}\text { Miocene to } \\
\text { middle } \\
\text { Eocene }\end{array}$ \\
\hline IIIa & $172.5-324.5$ & $\begin{array}{l}446-19, \mathrm{CC} \\
\text { through } \\
446-35, \mathrm{CC}\end{array}$ & 152.0 & $\begin{array}{l}\text { Dark-greenish-gray (56Y4/1), greenish- } \\
\text { gray ( } 5 \mathrm{GY} 5 / 1) \text { mudstones, claystones, } \\
\text { siltstones, and sandstones, in turbidite } \\
\text { sequences. }\end{array}$ & $\begin{array}{l}\text { Middle } \\
\text { Eocene }\end{array}$ \\
\hline IIIb & $324.5-362.5$ & $\begin{array}{l}446-36-1 \\
\text { to } \\
446-39, C C\end{array}$ & 38.0 & $\begin{array}{l}\text { Brown ( } 7.5 \text { YR } 5 / 4) \text {, dark-brown } \\
\text { ( } 7.5 \text { YR } 4 / 4) \text {, calcareous claystones and } \\
\text { mudstones, interbedded with dark- } \\
\text { greenish-gray ( } 5 \mathrm{GY} 4 / 1 \text { and } 5 \mathrm{G} 4 / 1) \text { to } \\
\text { greenish-gray ( } 5 \mathrm{G} 5 / 1) \text {, calcareous clay- } \\
\text { stones and mudstones, in turbidite } \\
\text { sequences, plus pelagic biogenic } \\
\text { components. }\end{array}$ & $\begin{array}{l}\text { Middle } \\
\text { Eocene }\end{array}$ \\
\hline \multirow[t]{2}{*}{ IV } & $\begin{array}{c}\text { Hole } 446 \\
362.5-395.7\end{array}$ & $\begin{array}{l}446-40-1 \\
\text { to } \\
446-43-3 \\
120 \mathrm{~cm}\end{array}$ & $\begin{array}{c}\text { Hole } 446 \\
17.9 \\
\text { (est.) }\end{array}$ & $\begin{array}{l}\text { Hole } 446 \\
\text { Dark-greenish-gray (5G4/1) to greenish- } \\
\text { gray (5G5/1) and bluish-green (5B4/1), } \\
\text { calcareous claystones, nannofossil clay- } \\
\text { stones, glauconitic claystones, mud- } \\
\text { stones, ash. }\end{array}$ & $\begin{array}{l}\text { Middle-early } \\
\text { Eocene }\end{array}$ \\
\hline & $\begin{array}{c}\text { Hole } 446 \mathrm{~A} \\
372.0-628.0\end{array}$ & $\begin{array}{l}446 \mathrm{~A}-1-1 \\
\text { through } \\
446 \mathrm{~A}-28 \\
\text { CC }\end{array}$ & $\begin{array}{l}\text { Hole } 446 \mathrm{~A} \\
\qquad 60 \\
\text { (est.) }\end{array}$ & $\begin{array}{l}\qquad \text { Hole 446A } \\
\text { As above, with abundant ash through } \\
\text { Core } 17 \text {. Sediment occurs as interbeds } \\
\text { between basalt sills. }\end{array}$ & \\
\hline
\end{tabular}



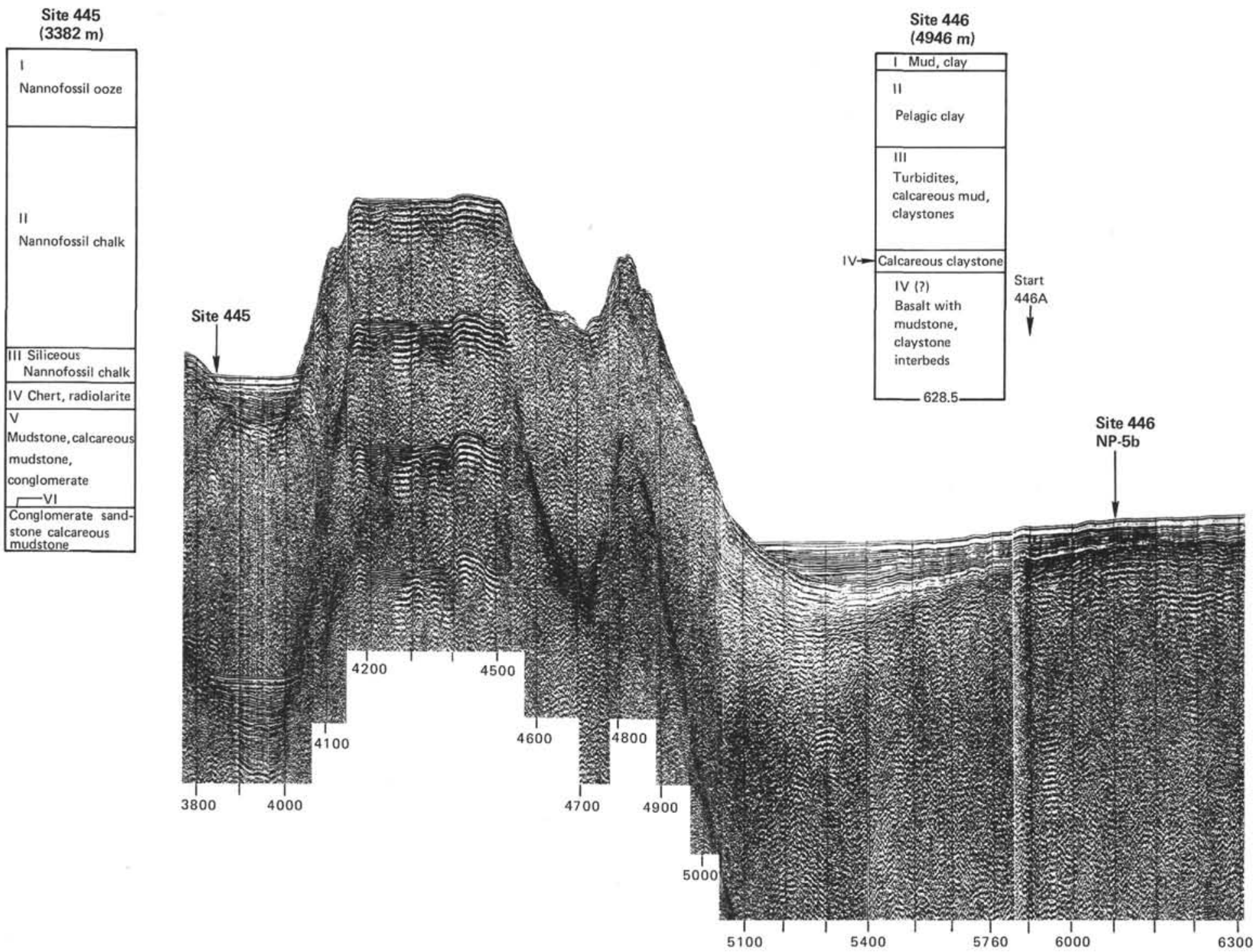

Figure 4. Stratigraphic sections at Sites 445 and 446, with seismic profile.

repetitive fining-upward turbidite sequences that make up this unit. Most of the fining-upward sequences begin with sandstone or sandy mudstone at the base, followed by mudstone with thin laminae of fine sand and silty sand, clayey mudstone, and (or) claystone. Rare interbeds of light-gray and greenish-gray, clayey chalk are present in the upper parts of the fine-grained turbidite sequences.

Most of the cycles are a half meter or less thick, and the fine mudstones or claystones at the tops of the cycles are the thickest part. Some of the thinner cycles, however, are actually subcycles in larger overall finingupward, thickening-upward sequences. The coarse basal part of each cycle in many cases has a sharp or scoured contact with the fine upper end of a preceding cycle. Cross-lamination may be present in the lower parts of cycles, and is more common in the lower section of subunit IIIa. Parallel laminae are generally present, but become more abundant and more closely spaced upward in each cycle. Evidence for minor bioturbation is present, generally in the upper half of cycles, but is not common in this sub-unit. Some of the mudstones are massive, with little visible evidence of any sedimentary structures. Evidence of slumping is rare; some smallscale slump structures are present in the lower part of the sub-unit.

Most of the sediments in this sub-unit contain abundant terrigenous components: relatively high proportions of feldspar (up to $30 \%$ ), heavy minerals (up to $25 \%$ ), lithic fragments (up to $40 \%$ ), and terrigenous clays (up to $90 \%$ ). Glauconite is present throughout, in quantities ranging from 1 to about 35 per cent. Small percentages of mica are present in almost all samples. There are significant (up to $10 \%$ ) quantities of opaque minerals (probably both terrigenous and authigenic) throughout the sub-unit, and minor percentages of zeolites. Calcareous biogenic components are minor constituents, except in interbeds of chalky clay in Cores $24,25,26,27,32$, and 34 . Siliceous biogenic components are generally absent.

We distinguish sub-unit IIIb from IIIa principally because of a change from dark-greenish-gray to brown 
and reddish-brown, and an increase in biogenic components. Sub-unit IIIb has thick sequences of brown, dark-brown, reddish-brown, and grayish-brown, generally calcareous mudstones and claystones, interbedded with dark-greenish-gray to greenish-gray, calcareous claystones and mudstones. The boundary between subunit IIIa and IIIb is not sharp; a gradual transition from sub-unit IIIa to sub-unit IIIb occurs in Core 36. The depositional sequences in sub-unit IIIb closely resemble those of IIIa; they are a series of fining-upward cycles. However, those in IIIb contain large proportions of both resedimented and pelagic biogenic components.

In the lower part of the sub-unit, we observed two complete turbidite cycles, each almost 1 meter thick, starting with coarse calcareous sandstone. The sandstones are cross-laminated as well as parallel laminated, and graded; they contain abundant foraminifers and nannofossils, along with terrigenous grains. They grade upward through calcareous mudstones and calcareous claystones which show parallel and(or) wavy laminations and bioturbation. Most of the sub-unit, however, consists of calcareous mudstone alternating with calcareous claystone in a series of fining-upward cycles with parallel laminations and slight to moderate bioturbation. Siliceous biogenic components form a significant part ( $10 \%$ or more) of the sediment in only two layers in Cores 37 and 38. Zeolites and micronodules are abundant in a mudstone that underlies a radiolarian-rich claystone in Core 37.

\section{Unit IV}

Unit IV consists of dark-greenish-gray to greenishgray to dark-gray calcareous claystones, nannofossil claystones, glauconitic claystones, and altered ash beds. The claystones are finely laminated and moderately bioturbated; they contain silty (fining-upward) and calcareous laminae, and some evidence of soft-sediment deformation. In Core 43, the claystones are glauconitic and contain vertical veins of clay and calcite.

This unit is also characterized by thicker $(1-5 \mathrm{~cm})$ ash and altered ash beds, which tend to be dark gray and massive and fine upward into claystones. The lower boundaries are sharp and well defined. Other lithologies include lithic sandstones, nannofossil claystones, and glauconitic sandstones.

Sediments of the section just above the second basalt cored in Core 43 consist of breccia fragments of clayey limestone, a zeolitic clayey limestone, and a glauconitic claystone at the basalt contact.

\section{Hole 446A}

Hole 446A was washed to a depth of 372 meters, where continuous coring began in sediments representing unit IV of Hole 446. Twenty-eight cores recovered 117.09 meters of sediment and basalt. Except for the first 10.3 meters of sediment above the first basalt contact, all other recovered sediments represent interbeds between basalts.

The thickness of the interbeds ranges from about 1 $\mathrm{cm}$ (several representative cores) to about 6.8 meters in Core 10 . Low recovery in some cores may have led to underestimation of thickness of some sediment interbeds.

We made no attempt to designate specific lithologic units.

\section{Sediment Interbeds}

Sediments occurring as interbeds include (in general order of abundance) mudstone and claystone; glauconitic sandy mudstone, mudstone and claystone; calcareous mudstone and claystone; and ashy mudstones and siltstones; as well as ash and altered ash beds or zones. Other sediments present in small amounts are zeolitic claystones, chalk or clayey chalk, lithic sandstones and siltstones, and chert.

Throughout the interbed section, sediment colors are dominantly dark-greenish gray, greenish gray, and grayish green, with variations into or tinges of dark gray, and bluish gray, and dusky red.

In some interbeds, overlying or underlying basalt, the sediments appear baked and assume dark-brown to black colors. This was particularly noticeable in Cores 12,25 , and 26 , where very obvious basalt/sediment contacts were recovered. These sediments are well indurated and have feldspar content as high as 35 per cent, zeolites up to 40 per cent, micronodules, and abundant glauconite.

The recovered sediments for the most part (mudstones and claystones) have the following characteristics: laminated bedding ( $1 \mathrm{~mm}$ to $1-2 \mathrm{~cm})$; silty laminations that fine upward into claystones; evidence of bioturbation; and soft-sediment deformation including microfaults, rip-up clasts, and clastic dikes. Other sedimentary structures include cross-beds, graded beds, and rippled or undulating bedding surfaces.

Ash zones occur throughout the cored interval, but we noticed a concentration of ash and altered ash higher in the cored section as compared to lower portions. The ash and altered-ash zones are present in Core 1 above the first basalt, and then in Cores 2, 3, 10 (up to 5 meters thick), 12, 13, 16, and 17. Below Core 17, we consider the occurrences minor.

\section{ORGANIC GEOCHEMISTRY}

Organic-carbon and nitrogen contents were measured in 59 samples. Results of the analyses are reported elsewhere (Waples and Sloan, this volume) and are plotted in Figure 5. In the section above the basalt sills, the maximum organic-carbon contents, about 0.1 per cent, occur in the youngest recovered sediments. The upper part of the carbon-depletion curve shows the same features as did curves for the other Leg 58 sites (Waples and Sloan, this volume). Because the youngest recovered sediments were Pliocene, however, much of the loss of organic carbon had already occurred; therefore the exponential decay observed in the uppermost part of the section at the other sites is barely visible. Organic-carbon values for the pelagic part of the section level out at a constant value (about $0.05 \%$ ) which is very similar to that found for the pelagic sequence at Site 445 . 


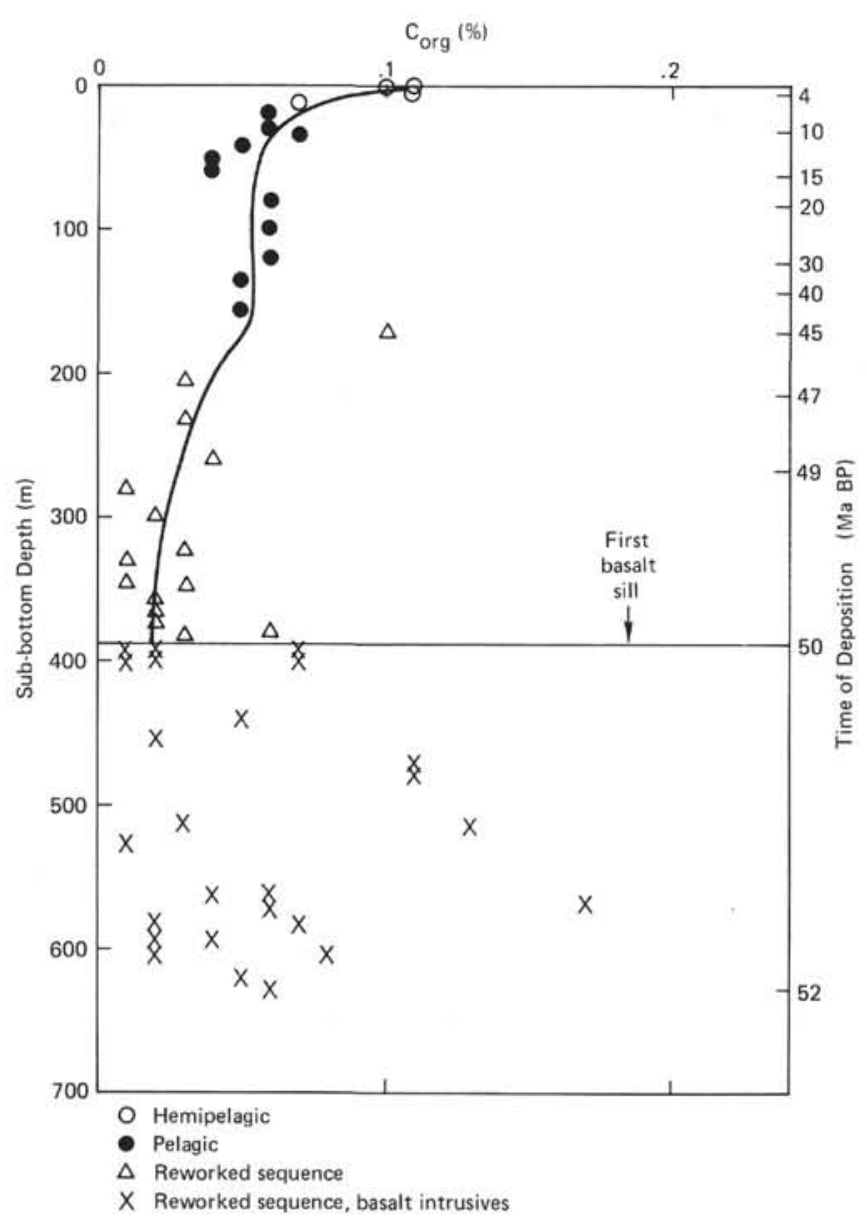

Figure 5. Organic carbon versus depth, Hole 446A.

There is another aspect of the organic-carbon-depth curve which differs from the results consistently obtained at the other sites. Although the organic-carbon values level off at about 0.05 per cent, they begin to decrease steadily again at a depth of about 160 to 200 meters, and reach values nearly at the lower limit of detection by our method $(0.01 \%)$. The causes for this second decrease and for the exceedingly low organiccarbon values are not known, but may be related to the fact that these sediments are current deposits, rather than pelagic. This period (47-50 Ma) was characterized by high sedimentation rates, as seen from the time scale in Figure 5.

Many samples from the sediments intruded by basalts were also analyzed, and the analyses are included in Table 3 . Several of these show relatively high organiccarbon contents $(0.10-0.17 \%)$, although they have been severely baked by lava. The causes for these high values seem to be quite different from those in the thermally affected sediments in Hole 444A (Waples, this volume), where the depositional mode was uniformly hemipelagic, both in the intruded sediment and in the overlying section. Here deposition seems to have been by turbidites in many of the inter-basalt sediments. This regime apparently gave over in later times to current
TABLE 3

Nitrogen and Organic- and Inorganic-Carbon Content of Sediments, Site 446

\begin{tabular}{|c|c|c|c|c|c|c|}
\hline $\begin{array}{c}\text { Sample } \\
\text { (interval in } \mathrm{cm} \text { ) }\end{array}$ & $\begin{array}{l}\text { Litho- } \\
\text { logic } \\
\text { Unit }\end{array}$ & $\begin{array}{l}\text { Sub-Bottom } \\
\text { Depth } \\
\text { (m) }\end{array}$ & $\underset{(\%)}{\mathrm{CaCO}_{3}{ }^{*}}$ & $\begin{array}{c}C_{\text {orp }} \\
(\%)\end{array}$ & $\begin{array}{l}\mathrm{N}^{\mathrm{b}} \\
(\%)\end{array}$ & $\begin{array}{l}\mathrm{C} / \mathrm{N}^{* *} \\
\text { (atomic) }\end{array}$ \\
\hline $446-1-1,18-19$ & 1 & 0.2 & - & .11 & .039 & 3.3 \\
\hline $1-1,105-106$ & 1 & 1.1 & - & .10 & .022 & 5.1 \\
\hline $2-1,44-45$ & 1 & 1.9 & - & .11 & .032 & 4.0 \\
\hline $3-2,89-90$ & I & 13.4 & - & .07 & .036 & 2.3 \\
\hline $3-6,89-90$ & II & 19.4 & - & .06 & .029 & 2.2 \\
\hline $4, \mathrm{CC}$ & II & 29.8 & - & .06 & .020 & 3.3 \\
\hline $5-3,76-77$ & II & 33.8 & - & .07 & .028 & 2.8 \\
\hline $6-2,82-83$ & II & 41.8 & - & .05 & .030 & 1.9 \\
\hline $7-2,88-89$ & II & 51.4 & - & .04 & .020 & 2.6 \\
\hline $8-2,68-69$ & II & 60.7 & - & .04 & .028 & 1.8 \\
\hline $10-2,144-145$ & II & 80.4 & - & .06 & .022 & 3.3 \\
\hline $12-2,75-76$ & II & 98.8 & - & .06 & .016 & 4.3 \\
\hline $14-4,40-41$ & II & 120.4 & - & .06 & .017 & 4.0 \\
\hline $16-2,30-31$ & II & 136.3 & - & .05 & .006 & 10.1 \\
\hline $18-1,137-138$ & II & 154.9 & - & .05 & .009 & 7.3 \\
\hline $20-1,66-67$ & III & 173.2 & + & .10 & .006 & 22.7 \\
\hline $23-2,77-78$ & III & 203.3 & - & .03 & .003 & 10.7 \\
\hline $26-4,19-20$ & III & 234.2 & - & .03 & .005 & 8.1 \\
\hline $29-1,34-35$ & III & 258.3 & - & .04 & .006 & 8.5 \\
\hline $31-2,89-90$ & III & 279.4 & - & .01 & .005 & 2.9 \\
\hline $33-2,51-52$ & III & 298.0 & & .02 & .005 & 5.5 \\
\hline $36-1,53-54$ & III & 325.0 & - & .03 & .003 & 10.3 \\
\hline $36-5,0-1$ & III & 330.5 & - & .01 & .006 & 2.7 \\
\hline $38-1,100-101$ & III & 344.5 & +t & .01 & .004 & 4.0 \\
\hline $38-3,100-101$ & III & 347.5 & - & .03 & .004 & 7.9 \\
\hline $39-1,70-71$ & III & 353.7 & - & .02 & .005 & 4.1 \\
\hline $40-2,5-6$ & IV & 364.1 & - & .02 & .001 & 22.1 \\
\hline $41-1,125-126$ & IV & 373.3 & + & .02 & .007 & 2.7 \\
\hline $446 \mathrm{~A}-1, \mathrm{CC}$ & IV & 381.3 & H & .06 & n.d. & n,d, \\
\hline $2-1,50-52$ & IV & 382.0 & - & .06 & n.d. & n.d. \\
\hline $2-1,68-70$ & IV & 382.2 & + & .03 & n.d. & n.d. \\
\hline $446-43-1,49-50$ & IV & 391.5 & & 02 & .008 & 2.6 \\
\hline $446 \mathrm{~A}-3-1,58-60$ & IV & 391.6 & & .07 & .002 & 37.6 \\
\hline $3-2,130-132$ & IV & 393.8 & + & .07 & .009 & 9.7 \\
\hline $446-43-2.130-131$ & IV & 393.8 & - & .01 & .002 & 6.7 \\
\hline $43-3,4-5$ & IV & 394.0 & ++ & .02 & .005 & 6.1 \\
\hline $43-3,119-120$ & IV & 395.2 & & .02 & .005 & 5.9 \\
\hline $43-4,0-2$ & IV & 395.5 & ++ & .01 & .001 & 2.9 \\
\hline $43-4,14-15$ & IV & 395.6 & & .02 & .004 & 5.9 \\
\hline $446 \mathrm{~A}-9-1,16-17$ & IV & 438.7 & + & .05 & n.d. & n.d. \\
\hline $10-5,62-64$ & IV & 454.6 & + & .02 & n.d. & n.d. \\
\hline $12 \cdot 3,105-106$ & IV & 471.1 & - & 11 & n.d. & n.d. \\
\hline $13-3,74-75$ & IV & 480.2 & + & .11 & n.d. & n.d. \\
\hline $16 . \mathrm{CC}$ & IV & 514.3 & + & .03 & .004 & 9.1 \\
\hline $17-2,57-59$ & IV & 516.6 & + & .13 & .017 & 8.8 \\
\hline $18-2,50-52$ & IV & 526.0 & - & .01 & .001 & 11.4 \\
\hline $22-1,65-66$ & IV & 562.7 & - & .06 & .001 & 52.8 \\
\hline $22-1,109-110$ & IV & 563.1 & - & .04 & .001 & 32.1 \\
\hline $22-1,122-123$ & IV & 563.2 & - & .17 & .007 & 29.1 \\
\hline $23-1.60-62$ & IV & 572.1 & - & .06 & .006 & 11.1 \\
\hline $24-1,109-110$ & IV & 582.1 & - & .02 & .004 & 6.5 \\
\hline $24-2,70-71$ & IV & 583.2 & - & .07 & .012 & 6.7 \\
\hline $25-3,71-72$ & IV & 594.2 & + & .04 & .004 & 12.1 \\
\hline $25-3,93-94$ & IV & 594.4 & - & .02 & .003 & 7.2 \\
\hline $25-3,99-100$ & IV & 594.5 & - & .02 & .008 & 2.3 \\
\hline $26-3,70-71$ & IV & 603.7 & - & .06 & .007 & 10.4 \\
\hline $26-3,104-105$ & IV & 604.0 & - & .02 & .002 & 15.8 \\
\hline $28-1,23-24$ & IV & 619.2 & + & .05 & .003 & 21.9 \\
\hline $28, \mathrm{CC}$ & IV & 628.3 & ++ & .06 & .010 & 7.1 \\
\hline
\end{tabular}

${ }^{*}=$ = no carbonate detected with conc. $\mathrm{HCl} ;{ }^{*}{ }_{\text {n.d. }}=$ not determined.

$+=$ small amount of carbonate present $;++=$ large amount of carbonate present.

deposits, and finally to a pelagic environment. Because of the inconstancy of the depositional environment during this time interval, there is no way to correlate the quantities of residual organic carbon in the baked sediments with the carbon-depletion curve, and no dating of the sills (as for Site 444; Waples, this volume) can be attempted.

Both the highly variable organic-carbon values, which bear no apparent relation to distance from the basalt sills, and the low nitrogen contents of many of 
the interbasalt sediments support some sort of resedimentation mechanism which brought varying but small amounts of terrestrial organic material to this location.

\section{INORGANIC GEOCHEMISTRY}

Samples for interstitial-water studies were taken from the recovered sediments at Holes 446 and 446A. In total, 11 samples were taken, eight from Hole 446, and three from Hole 446A. The samples are representative of lithologic units II, IIIa, and IV. All data are found in Table 4 and Figure 6.

\section{$p \mathbf{H}$}

$p \mathrm{H}$ averages 8.10 , higher than the IAPSO standard and lower than the surface-sea-water standard. The general trend is an increase in $p \mathrm{H}$ with depth, to Cores 446-41 and Core 446A-3. $p \mathrm{H}$ below these cores decreases. Sediments below Core 446A-3 (unit IV) are interbedded with basalt intrusions, whereas all other sediments occurred above the basalt.

\section{Alkalinity}

Alkalinity averaged $1.02 \mathrm{meq} / \mathrm{kg}$, below the value for the two standards. Alkalinity decreases relatively sharply with increasing depth to Core 446-21, being generally constant in lower cores. A slight increase in alkalinity is noted for Cores 446A-3 through 446A-25; these samples represent the interbedded (unit IV) sediments of Hole 446A.

\section{Salinity and Chlorinity}

Salinity averaged 36.6 per mill, and chlorinity 19.6 per mill, both higher than the two standards. Trends of the two parameters are closely matched, as expected, and values of both parameters increase with depth to Core 446-41. Salinity and chlorinity for cores from Hole 446A show considerable variability, decreasing from Core $446 \mathrm{~A}-3$ to Core $446 \mathrm{~A}-10$, then increasing again to Core 446A-25.

\section{$\mathrm{Ca}^{++}$and $\mathrm{Mg}^{++}$}

$\mathrm{Ca}++$ averages $74.86 \mathrm{mmol} / 1$, considerably higher than the standards, whereas $\mathrm{Mg}++$ averages $17.62 \mathrm{mmol} / 1$, lower than the standards.

$\mathrm{Ca}^{++}$shows a definite trend to increase with depth, whereas $\mathrm{Mg}++$ decreases with depth. A crossover of these two trends occurs in Core 446-14, which is the lowermost sample taken from unit II sediments. This crossover thus occurs at the interval where the sediments change from dominantly pelagic in unit II to hemipelagic in unit III.

\section{BIOSTRATIGRAPHY}

Site 446 is characterized by very low sedimentation rates in the upper part of the section and very high sedimentation rates in the lower part, by poor preservation of all microfossils, and by intrusion of sediments intruded by basalt sills at the bottom of Hole 446 and throughout Hole 446A.

The present water depth of Site 446 is 4952 meters, which is well below the CCD. Sedimentation at this site is believed to have been below the CCD; this and the low rates have resulted in poor preservation of calcareous fossils. Sporadic zones of good preservation are due to special conditions. The lower part of the sediments (Cores 20-43 in Hole 446; all of Hole 446A) shows occasional moderately well- to well-preserved calcareous microfossils. Since they often include shallow-water benthic foraminifers and occur with resedimented material, they either come down-slope with the shallower sediment and were originally deposited above the CCD, or were covered in place and protected from dissolution by the overlying sediments. Well-preserved radiolarians are seen in abundance only in two cores. Once (Core 9), they are associated with an ash layer, and in Core 17 with the uppermost chert. All three of these modes of preservation are often seen in deep-sea sediments.

Because of the sporadic occurrence of microfossils at Site 446 , the biostratigraphy is fragmentary. Fortunate-

TABLE 4

Summary of Shipboard Geochemical Data for Holes 446 and 446A

\begin{tabular}{ccccccccc}
\hline $\begin{array}{c}\text { Sample } \\
\text { (interval in cm) }\end{array}$ & $\begin{array}{c}\text { Sample } \\
\text { Number }\end{array}$ & $\begin{array}{c}\text { Sub-Bottom } \\
\text { Depth } \\
(\mathrm{m})\end{array}$ & $p \mathrm{H}$ & $\begin{array}{c}\text { Alkalinity } \\
(\mathrm{meq} / \mathrm{kg})\end{array}$ & $\begin{array}{c}\text { Salinity } \\
(\% / \mathrm{oo})\end{array}$ & $\begin{array}{c}\mathrm{Ca}++ \\
(\mathrm{mmol} / \mathrm{l})\end{array}$ & $\begin{array}{c}\mathrm{Mg}^{++} \\
(\mathrm{mmol} / \mathrm{l})\end{array}$ & $\begin{array}{c}\mathrm{Cl}^{-} \\
(\%)\end{array}$ \\
\hline- & IAPSO & - & 7.96 & 2.50 & 35.2 & 10.55 & 53.99 & 19.375 \\
- & SSW & - & 8.31 & 2.40 & 35.2 & 10.80 & 52.60 & 19.208 \\
$446-3-5,140-150$ & 42 & $18.40-18.50$ & 7.51 & 2.63 & 35.5 & 17.31 & 46.23 & 19.441 \\
$9-4,90-100$ & 43 & $73.40-73.50$ & 7.19 & 2.11 & 35.8 & 28.59 & 41.53 & 19.408 \\
$14-4,144-150$ & 44 & $121.44-121.50$ & 7.31 & 1.82 & 35.8 & 37.54 & 36.59 & 19.075 \\
$21-2,144-150$ & 45 & $184.94-185.00$ & 8.13 & 0.53 & 36.3 & 54.75 & 21.10 & 19.541 \\
$26-2,140-150$ & 46 & $232.40-232.50$ & 8.34 & 0.58 & 36.3 & 68.66 & 12.97 & 19.608 \\
$30-5,140-150$ & 47 & $274.90-275.00$ & 7.87 & 0.60 & 36.3 & 79.84 & 12.89 & 19.808 \\
$34-5,140-150$ & 48 & $312.90-313.00$ & 8.25 & 0.35 & 36.3 & 85.68 & 3.05 & 19.475 \\
$41-2,140-150$ & 49 & $374.90-375.00$ & 8.71 & 0.42 & 36.6 & 98.81 & -1.78 & 19.808 \\
$446 \mathrm{~A}-3-3,0-10$ & 50 & $394.00-394.10$ & 8.88 & 0.83 & 38.5 & 110.48 & -4.87 & 20.041 \\
$10-2,140-150$ & 51 & $450.90-451.00$ & 8.73 & 0.58 & 36.6 & 109.70 & -6.38 & 19.508 \\
$25-3,140-150$ & 52 & $594.90-595.00$ & 8.19 & 0.82 & 38.5 & 132.07 & -6.42 & 19.907 \\
\hline
\end{tabular}




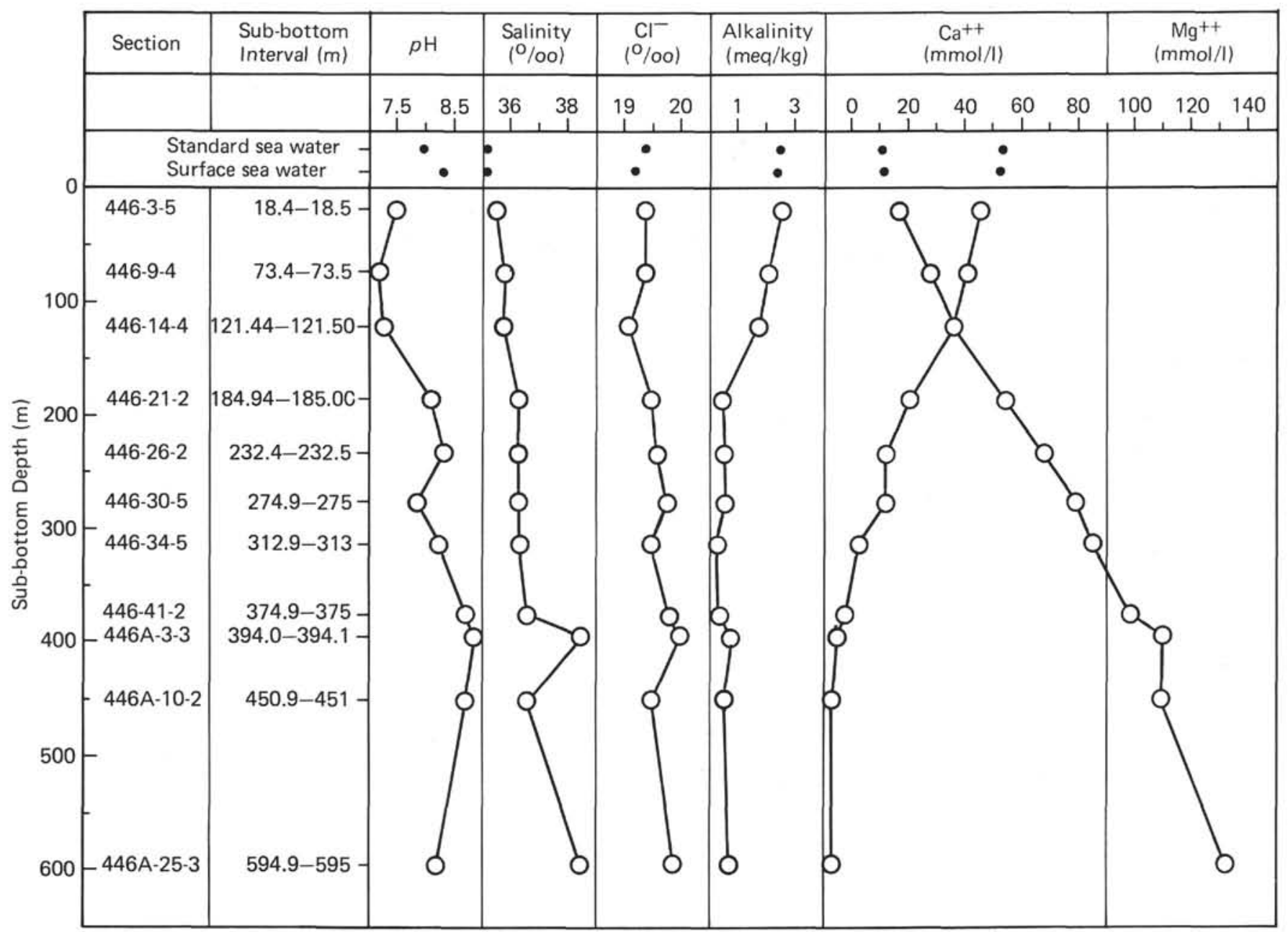

Figure 6. Interstitial-water geochemistry, Holes 446 and $446 \mathrm{~A}$.

ly, the areas of preservation good enough to give an age determination are spaced rather evenly throughout the hole (Table 5).

The oldest sediments found, excluding reworked Cretaceous material, are late early Eocene (50-52 m.y.) for Hole 446. Core 1 of Hole 446A corresponds to Core 41 of Hole 446. All sediments from 446A are of the same age (50-52 m.y.), and all dates for Hole 446A are from scattered foraminifer and nannofossil occurrences.

Throughout the section, reworking is evident. It increases down-hole, and is severe from Core 20 on. Displaced Eocene shallow-water benthic foraminifers are found throughout this part of the section.

Core 40 contains a small amount of reworked Upper Cretaceous sediment. It contains nannofossils and both planktonic and benthic foraminifers. We believe that this material represents at least two episodes of transportation and deposition.

\section{Foraminifers}

Foraminifers recovered from the two holes drilled at Site 446 spanned the early Eocene through the Pliocene. (A few macerated Cretaceous forms were found incorporated in one of the lower-Eocene turbidites.)
One core in Hole 446, at approximately 182 meters, contained a shallow-water benthic fauna of Nummulites, Amphistegina, and Lenticulina; the source of this material is not known. In Hole 446A, at approximately 480 meters, a diverse benthic fauna which contained the shallow- and warm-water genus Asterocyclina was recovered. The oldest reliable date for sediments drilled at this site is 51 to $52 \mathrm{~m} . \mathrm{y}$.

\section{Hole 446}

The first core recovered from Hole 446, at 1.5 meters below the sea floor, was Pliocene. Globorotalia tosaensis, G. inflata, G. tumida, and Sphaeroidinella dehiscens dominate the planktonic assemblage. The present depth of water at the site is 4952 meters, which is below the solution depth of calcium-carbonate foraminifers.

The Pliocene record in this hole is very short: Core $2, \mathrm{CC}$ at 11 meters indicates very early Pliocene (N.19). The characteristic planktonic forms show effects of solution. The benthic forms are moderately well preserved and are represented by a diverse assemblage which indicates a deep-water marine environment (upper bathyal; $\sim 500 \mathrm{~m}$ ). A middle-Miocene fauna was recovered from Core 3, Section 1. The foraminifers are 
TABLE 5

Biostratigraphic Zones, Site 446

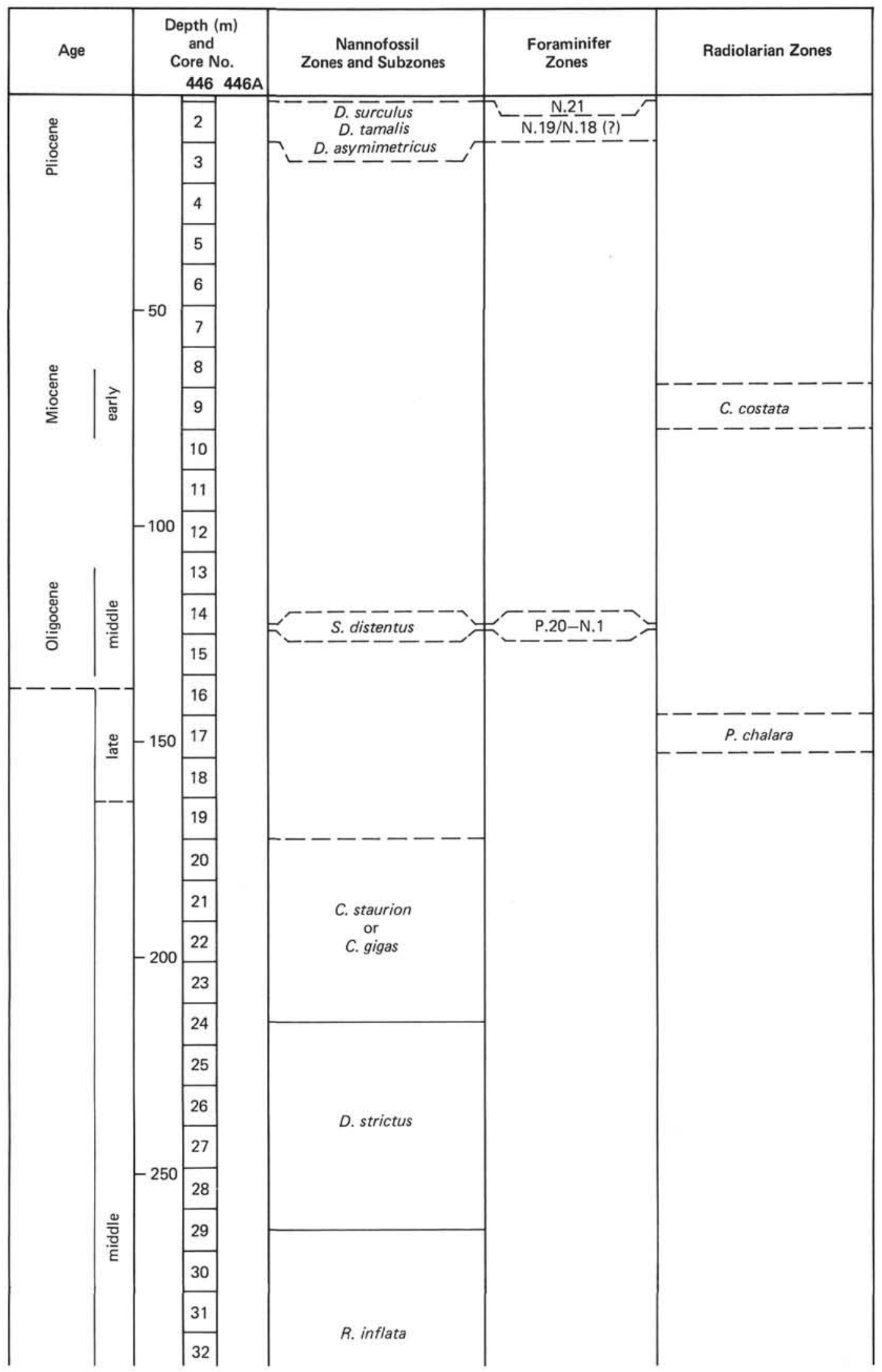


TABLE 5 - Continued

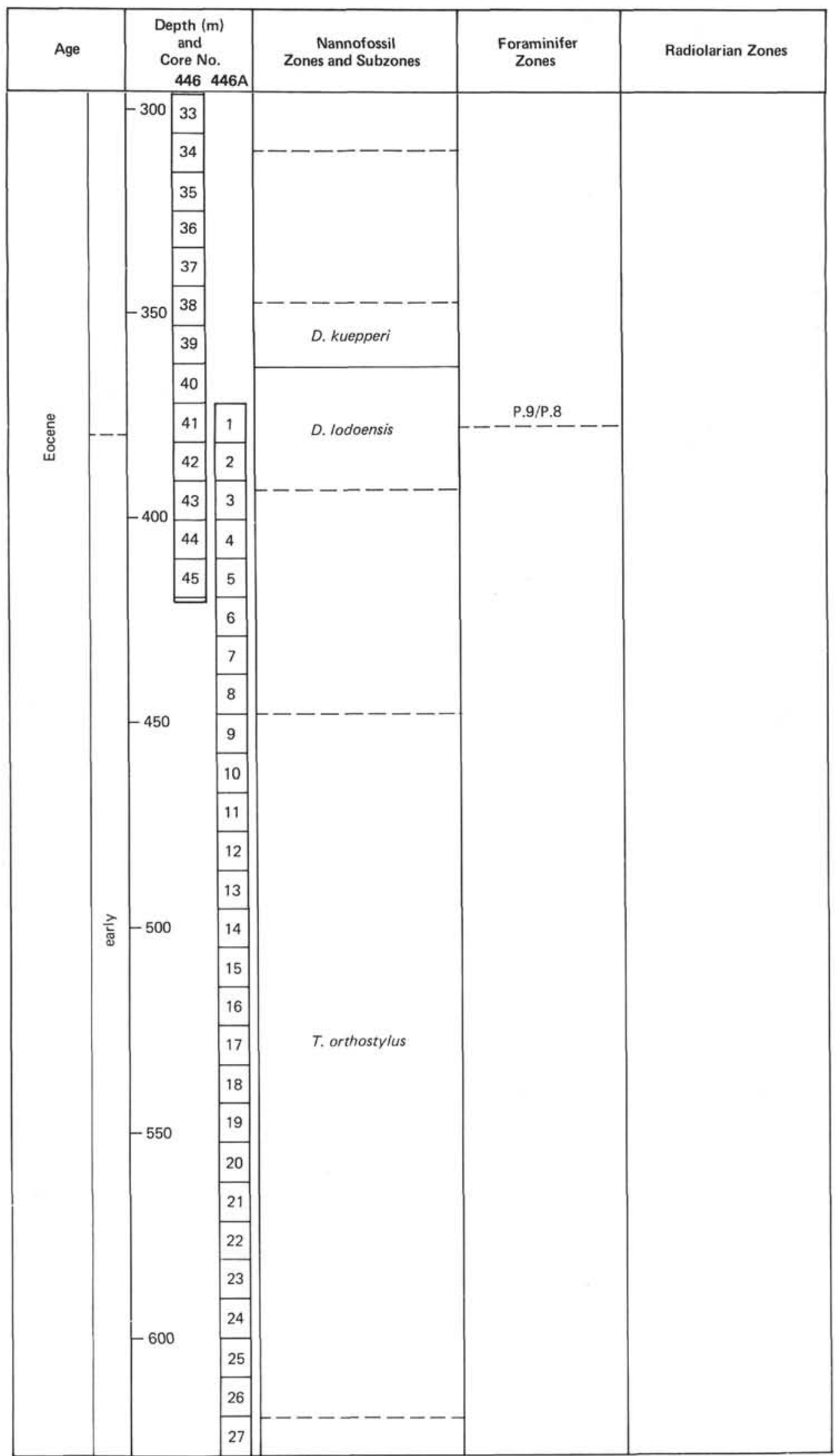


not abundant, and preservation is poor. However, the fragmented index species do suggest a middle-Miocene age. This indicates that material representing the lateMiocene foraminifer zones was not recovered in this hole. Cores 5 to 13 , to a depth of 115 meters, are barren of recognizable foraminifers. Interpretation of this section must await further study to determine whether microforaminifer-sized individuals are present.

In Core 14, at approximately 120 meters, a normalsized, fairly diverse planktonic and benthic foraminifer fauna can be identified as Oligocene. The species are indicative of the Globigerina ampliapertura Zone (N.1/ P.20; 30-32 m.y.). The benthic forms and ostracodes indicate an open-water marine environment. From this depth down to 180 meters, sediments contain only rare casts of foraminifers. In the core catcher of Core 20, in a redeposited rubble of green sandstone, common shallow-water Eocene benthic foraminifers belonging to Nummulitidae, Amphisteginidae, and Nodosaridae were recovered. In Core 23, at approximately 210 meters, middle-Eocene planktonic forms occur in turbidites with shallow-water benthic forms. This sample also contain benthic and planktonic microforaminifers; and as mentioned previously, the environmental significance of these tiny forms is not clear.

The next important foraminifer assemblage was found in Core 34, Section 4 in which planktonic species of the late early Eocene were found. Approximately 50 meters below this, material in Core 40 also suggests the late early Eocene, possibly P.9/P.8.

Another sample taken from this core catcher, within $10 \mathrm{~cm}$ of the Eocene material, contained silicified and distorted, reworked Cretaceous planktonic and benthic forms.

Basalt was encountered in the core catcher of Core 41 , and interspersed sediments of Eocene age were recovered from Cores 42 and 43 . The foraminifers in Core 43 are badly worn, reworked, shallow-water benthic forms.

\section{Hole 446A}

This hole was washed down to a depth of 372 meters. Core 1 contained a badly worn planktonic and benthic fauna of the late early Eocene. Core 2 recovered basalt; below, sediments interspersed between basalt sills were either barren or contained severely worn and crushed tests. Core 13 is of interest because if contains a transported warm- and shallow-water benthic fauna of $\mathrm{As}$ terocyclina, Amphistegina, Cibicides, and Planulina. The accompanying planktonic forms are of the early Eocene (51-52 m.y.), and this represents the oldest sediment recovered from the hole.

\section{Nannofossils}

Because of the great water depth (well below the present (CD), the occurrence of nannofossils was minimal at this site. Sporadic nannofossils representing the middle Pliocene and middle Oligocene occur in two of 19 upper cores. Preservation of the Pliocene nannofossils is moderate, the fossils suffering some etching, whereas preservation is poor for the Oligocene fossils because of recrystallization. In the lower cores, where Eocene turbidites are encountered, nannofossils are preserved more frequently. Heavy reworking prevails in this sequence, and nannofossil preservation is generally moderately good to poor because of a combination of etching and recrystallization. Age identification is summarized in Table 5.

\section{Pliocene}

Sample 446-2-1, $53 \mathrm{~cm}$ contains common nannofossils. Although heavy reworking of early Miocene to early Pliocene forms hampers age identification, several Pliocene discoasters, together with Pseudoemiliania sp. aff. $P$. lacunosa, suggest a middle-Pliocene assemblage of the Discoaster asymmetricus Subzone or the lower part of the Discoaster brouweri Zone (D. tamalis or D. surculus Subzone). A similar assemblage without $P$. sp. aff. $P$. lacunosa identifies the $D$. asymmetricus Subzone for Section 2,CC.

\section{Oligocene}

Cores 446-3 through 446-14-3 are barren of nannofossils. Section 14-5 contains approximately $10 \mathrm{~cm}$ of calcareous ooze. No reworking has occurred in this ooze, and the assemblage indicates the Sphenolithus distentus Zone of the middle Oligocene. Sections 14,CC to $19, \mathrm{CC}$ are barren of nannofossils.

\section{Eocene}

Rare specimens of Chiasmolithus gigas occur in restricted intervals of Sections 20-1 to 23,CC. Reworking is common in these cores, and the last occurrence of $C$. gigas is not clear. Therefore, the $C$. gigas and $\mathrm{Coc}$ colithus staurion Subzones are assigned to this sequence. Cores 25-1 to 29-1 represent the Discoaster strictus Subzone. Cores 29-2 to 37-1 are barren of nannofossils, except in two short intervals of Sections 30-1 and 34-4 which contain an assemblage of the Rhabdosphaera inflata Subzone. Cores $38-4$ to $39, \mathrm{CC}$ belong to the Discoasteroides kuepperi Subzone, and Cores 40-2 to 43-2 represent the Discoaster lodoensis Zone.

Approximately $10 \mathrm{~cm}$ of light-bluish-green sediment overlying $3 \mathrm{~cm}$ of dark-green sediment was recovered as one solid piece of rock in Section 40,CC. The boundary of these two sediments indicates turbidite deposition. The light-colored material contains abundant nannofossils whose assemblage is about 90 per cent Cretaceous nannofossils and about 10 per cent early-Eocene species. On the other hand, the dark-green sediment yields common nannofossils consisting almost equally of Cretaceous and early-Eocene fossils. The early-Eocene assemblage in both sediments clearly indicates the $D$. lodoensis Zone, whereas the Cretaceous flora indicates an age of Albian or Cenomanian. This suggests that Cretaceous chalk on the adjacent ridges was redeposited at this site by a turbidite flow during the late early Eocene.

Beneath the first basalt sill, approximately 5 meters of sediment was recovered in Core 43 . The assemblage of nannofossils in this sediment is almost identical with that observed in Section 41-2, and the common occur- 
rence of Coccolithus crassus confirms that this sediment represents the $D$. lodoensis Zone.

Cores 1 to 3 of Hole 446A were drilled to recover the same sediments as Cores 41 to 43 of Hole 446; naturally, the nannofossils are similar. Small pieces of lightbluish-green sediment which contain reworked Cretaceous nannofossils were recovered in Section 446A$1-1$. Cores $446 \mathrm{~A}-4$ to $446 \mathrm{~A}-8$ are all basalt. Between Cores $446 \mathrm{~A}-9$ and 28 , many alternative sequences of basalt and sedimentary rock were recovered. Nannofossils are sporadic in this sequence, and the assemblage indicates the Tribrachiatus orthostylus Zone of the late early Eocene. Therefore, the age of the oldest sediment recovered at this site is about 50 to $52 \mathrm{~m}$.y. This sediment does not contain any reworked nannofossils.

\section{Radiolarians}

Well-preserved radiolarians at Site 446 are rare. Two cores ( 9 and 17) provided abundant radiolarians in a state of excellent preservation. Every other core is either barren of radiolarians (Cores 1-8 and 10-16) or the radiolarians are altered beyond specific recognition (Cores $18-43$ ). Site 446 , although it has a poor radiolarian biostratigraphic record, provides an excellent opportunity to observe the preservational and diagenetic history of the radiolarians.

The two biostratigraphic "windows" are late early Miocene in Core 9 and early late Eocene in Core 17. Core 9 contains Stichocorys delmontensis, S. wolffii, Calocycletta costata, and Crytocapsella cornuta, which indicates an age of 15 to 17 m.y., Calocycletta costata Zone. Core 17 is in the Podocyrtis chalara Zone (44-45 m.y.) and contains the Eocene species Rhabdolithis pipa, Lithochytris vespertilio, Eusyringium fistuligerum, Thyrsocyrtis triacantha, and Calocyclas hispida. Both cores contain many tropical species.

The radiolarians of Hole 446A are similar to those of the bottom of Hole 446. Evidence of recrystallization is evident in all the cores with sediments. No cores contain radiolarians preserved well enough for age determination.

\section{SEDIMENTATION RATE}

An age-depth plot is shown in Figure 7. The sediment ages were obtained using the time-scales of Berggren (1972), Berggren and Van Couvering (1974) and Bukry (1975) and the modified Miocene time-scale of Saito (1977). Table 6 shows sediment accumulation rates calculated for each stratigraphic unit.

The sediment accumulation rates at Site 446 show a systematic change down-hole, similar to changes observed at Site 445 , although the reasons for the change are different. Rates are very low for the last $44 \mathrm{~m} . \mathrm{y}$. of deposition (Pleistocene through very late middle Eocene), because the sedimentation pattern was dominantly pelagic with a terrigenous influx only during the Pliocene (unit I). Sedimentation rates show an increase to moderate values for the middle and early Eocene at Site 446. The sudden increase in sediment accumulation rate is attributed to the influx of sandy turbidites during the

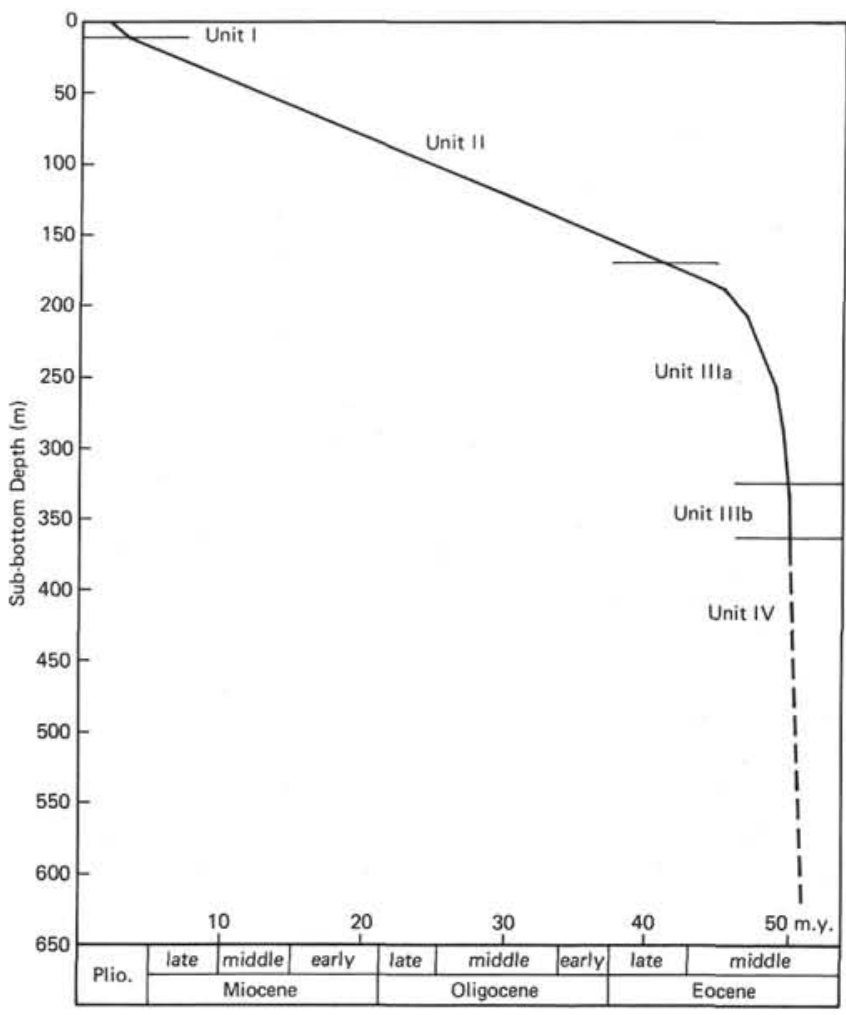

Figure 7. Sedimentation-rate curve for Site 446, based on biostratigraphic determinations. For unit IV, thickness of sediment is based on adding thicknesses of recovered sediment according to core-description sheets. Because of inaccuracies and poor recovery, the curve for unit $I V$ is dashed.

TABLE 6

Sedimentation Rates, Site 446

\begin{tabular}{lccc}
\hline Unit & $\begin{array}{c}\text { Depth } \\
(\mathrm{m})\end{array}$ & $\begin{array}{c}\text { Interval } \\
\text { Thickness } \\
(\mathrm{m})\end{array}$ & $\begin{array}{c}\text { Sedimentation } \\
\text { Rate } \\
(\mathrm{m} / \mathrm{m} . \mathrm{y} .)\end{array}$ \\
\hline I & $0.0-14.2$ & 14.2 & 2.5 \\
II & $14.2-172.5$ & 158.3 & 4.0 \\
IIIa & $172.5-324.5$ & 152.0 & 36.2 \\
IIIb & $324.5-362.5$ & 38.0 & 63.3 \\
IV & $362.5-628.5$ & $69.0^{\mathrm{a}}$ & 31.4 \\
\hline
\end{tabular}

a Sediment thickness based on total sediment recovered between basalt sills.

early and middle Eocene into the Daito Basin at Site 446.

Although the pattern of sediment accumulation rates parallels that of Site 445 , and also Sites 285 and 286 (Andrews, Packham et al., 1975; Klein, 1975) in the South Fiji and New Hebrides marginal basins, respectively, the overall rate is much lower at Site $\mathbf{4 4 6}$ in the Daito Basin, because pelagic clays are dominant (Site 446) and the sandy-turbidite units are thin compared to those at Sites 445, 285, and 286. Because deposition at Site 446 was at or near the CCD, Pleistocene or other changes in productivity do not appear to have influenced the sediment accumulation rate there. 


\section{IGNEOUS PETROLOGY}

\section{Introduction}

In Hole 446A, basalt was first encountered at approximately 384 meters sub-bottom and was drilled to 628.5 meters sub-bottom. Basement consists of massive basalt sills with numerous interbeds of claystone, mudstone, and volcanic ash (Figures 8 and 9). In all, at least 23 sills and 16 sediment interbeds were drilled. Based on proportionate expansion of recovery to fill the entire drilled interval, the average sill thickness is approximately 7.8 meters (ranging from 22.0 to 0.3 meters), and the average sediment interbed is approximately 4.04 meters thick (ranging from 14.8 to 0.2 meters). Hole 446 was aborted because of weather after relatively short basement penetration, and because the basement stratigraphy is identical to that at Hole 446A, the two sites are discussed here together as Site 446 , except where specified.

Numerous baked sediment contacts are present both below and above individual sills. In many cases the sediment still adheres to the igneous contact. The sediment typically is very hard at the contact, and chunks will readily scratch glass, whereas away from the contact the sediment can be scratched easily with a fingernail. The sediment is also generally discolored adjacent to igneous contacts, ranging from green to brown to gray-brown and gray-black at the contact; locally it may also appear brick red or bleached white. The effects of baking on the sediment appeared to vary considerably; there was a greater effect on overlying sediment than on underlying

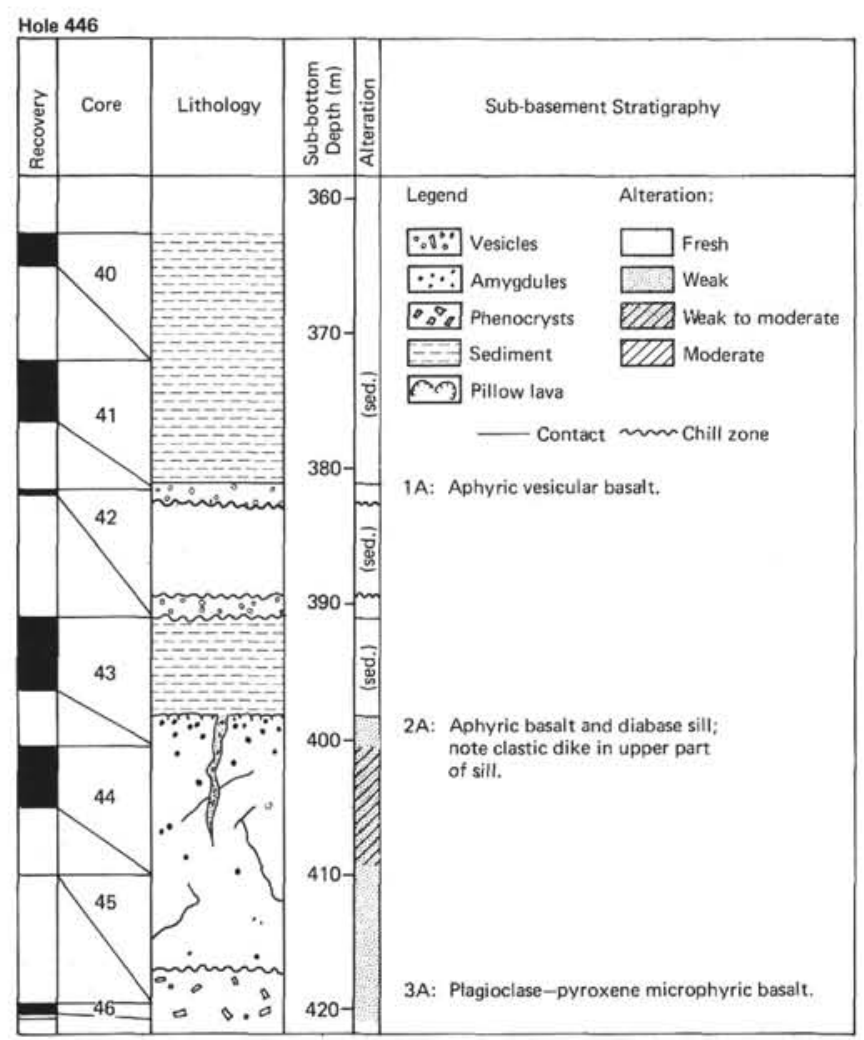

Figure 8. Sub-basement stratigraphy, Hole 446. sediment. Because of poor recovery, it is difficult to give accurate estimates of the thickness of the baked zones, but in various cores it appears to range from centimeters to a meter.

The chill zones found in the basalt at contacts also appear to be highly variable. In a few instances, glassy zones up to $2 \mathrm{~cm}$ were found, but in general, as in the Shikoku Basin, the sills tend to have fine-grained or aphanitic contacts, poor in glass.

Interestingly, the sills were generally finer grained than those drilled during Leg 58 in the Shikoku Basin. Only in a few cases was diabase actually recovered. Nonetheless, on the basis of the baked contacts, rarity of chill zones, lack of glass at the chilled margins, and massive nature of the basalt, it is clear that the Site 446 basalts are sills intruded into the sediment.

\section{Fractures and Veins}

Fracturing and the subsequent formation of veins is evident in nearly all the basalt cores. In many instances rocks are crisscrossed by several generations of veins formed along fracture surfaces. Vein fillings at Holes 446 and 446A differ substantially from those in the sills from the Shikoku Basin. Clay is the most common filling while carbonate, although very abundant, is less common. Pyrite and pyrrhotite are also exceptionally abundant as vein fillings at Site 446. Curiously, units 4B and $4 \mathrm{C}$, unlike all the other sills, contain abundant thick carbonate veins, and in this respect are very similar to veins in the Shikoku Basin sills. Quartz was found along with clay in unit $2 \mathrm{~A}$ of Hole $446 \mathrm{~A}$, and numerous clastic dikes were found in the same unit in Hole 446. The clastic dikes can be traced into zones of green, chloriticappearing clay, recrystallized carbonate, and quartz. Zeolites also form vein fillings in some of the sills.

\section{Petrography}

The most common basalt is aphyric, with about 20 to 35 per cent plagioclase $\left(\mathrm{An}_{60}\right.$ to $\left.A n_{78}\right), 15$ to 25 per cent clinopyroxene, and 7 to 20 per cent titanomagnetite, in a highly altered intersertal groundmass of clay, zeolites, and chlorite. Plagioclase and clinopyroxene phyric basalts are also common. In general, phenocrysts are small, averaging $1 \mathrm{~mm}$ in length and not exceeding 4 $\mathrm{mm}$. Microphenocrysts from 0.5 to $1.0 \mathrm{~mm}$ are far more common than phenocrysts. In the thin sections examined, olivine is no longer present, because of alteration. Olivine pseudomorphs filled with clay, talc, iddingsite, calcite, and chlorite were identified in nine sills. Generally, it appears to have been a fairly common phenocryst and microphenocryst, amounting to as much as 4 or 5 per cent in some rocks. In one case, 30 to 40 per cent large olivine relics appear to be present. Because of intense alteration, identification of groundmass olivine is impossible. The vesicularity of these basalts is generally low, although locally there may be as much as 15 per cent vesicles.

Units 1,4 , and 5 are clearly unlike ocean-ridge basalts, containing 10 to 15 per cent basaltic hornblende and 20 to 40 per cent vesicles. In addition, the pyroxene is very pink, apparently reflecting a high titanium con- 
tent, and titanomagnetite is exceptionally abundant $(8-25 \%)$. These basalts have an intergranular texture, unlike all the rest of the Site 446 basalts, and in some cases are very coarse grained. Unit $4 \mathrm{~A}$, in fact, consists of coarse diabase with 30 to 40 per cent vesicles.

\section{Unit 1}

Unit 1 consists of aphyric, highly vesicular basalt. It contains from 10 to 15 per cent kaersutite, 20 to 30 per cent plagioclase $\left(\sim \mathrm{An}_{70}\right), 15$ per cent clinopyroxene, and 15 to 25 per cent titanomagnetite. The rocks range from fine to medium grained and have an intergranular texture, with little evidence of alteration. The pyroxene is pink, suggesting high titanium contents. The hornblende is fresh and is clearly primary, although in places it also is either replacing clinopyroxene or forming an overgrowth on it.

There are two sills in unit 1, both of which are highly vesicular. Baked sediment was found above the contacts of both sills in either Hole 446 or 446A. The lower unit, however, apparently has a somewhat irregular contact, with intermixing of sediment and basalt. This might be due to intrusion into relatively unconsolidated sediment and formation of incipient pillow structures.

\section{Unit 2}

Unit 2 consists of a single thick aphyric basalt sill. No chilled contact was found. The sill is highly vesicular in its upper part, while vesicles are nearly absent in the lower half. The basalt is fine to medium grained, with an intersertal texture. It contains abundant plagioclase laths $\left(\mathrm{An}_{65}-\mathrm{An}_{75}\right)$, granular clinopyroxene, and about 10 per cent titanomagnetite. Rare olivine pseudomorphs also appear to be present. Clay, quartz, and pyrite are common fracture fillings, and several excellent examples of clastic dikes are present. The sediment in the dikes consists of angular claystone fragments of various colors, in a fine-grained claystone matrix. Relatively unaltered sediment can be traced into highly altered zones of green chloritic clay, pyrite segregations, carbonate, and recrystallized quartz.

\section{Unit 3}

Unit 3 consists of three plagioclase and plagioclaseclinopyroxene phyric basalt sills, separated by two sediment interbeds. The upper unit consists of plagioclase $(40 \%)$ and clinopyroxene $(\sim 1 \%)$ microphyric basalt, which has an intersertal texture and a felty groundmass of plagioclase laths, pyroxene, titanomagnetite granules, and alteration products. The middle sill (3B) consists of plagioclase (3-15\%) and pyroxene $(0-8 \%)$ phyric basalt, with a groundmass of plagioclase $\left(\mathrm{An}_{65}{ }^{-}\right.$ $\mathrm{An}_{68}$ ), clinopyroxene, and 10 to 15 per cent skeletal or granular titanomagnetite. A few relict olivine pseudomorphs are also present in some thin sections. The middle sill ranges from fine to medium grained and contains from 0 to 5 per cent vesicles. The lower sill (3C) consists of very sparsely phyric plagioclase and clinopyroxene basalt. Plagioclase phenocrysts exceed clinopyroxene although together they amount to only 1 to 4 per cent of the rock. The groundmass consists of plagioclase
$\left(\mathrm{An}_{66-76}\right)$, clinopyroxene, up to 15 per cent titanomagnetite, and alteration products. The pyroxene has a slight brown tint. The sill is fine grained, with 0 to 10 per cent vesicles, and calcite- and clay-filled amygdules. The vesicles appear to be largely empty in the lower half of the sill. Chill zones were recovered only at the upper contacts of units $2 \mathrm{~A}$ and $2 \mathrm{C}$.

\section{Unit 4}

Unit 4 can be split into 3 sub-units.

Sub-unit $4 \mathrm{~A}$ consists of a very vesicular $(25-40 \%$, 0.1-3.0 mm), aphyric, aphanitic to coarse grained, grayblack diabase. The vesicles often contain euhedral calcite rhombs and pyrite. The high vesicularity and coarse, elongate grains give the diabase a skeletal appearance.

Thin sections show an intergranular texture composed of 30 per cent plagioclase laths $(0.05-6.0 \mathrm{~mm}$; $\left.\mathrm{An}_{67}\right), 10$ per cent pinkish-brown pyroxene laths (0.2-4.0 mm), 15 per cent basaltic hornblende (0.1-2.0 $\mathrm{mm})$, and 10 per cent titanomagnetite $(0.02-0.4 \mathrm{~mm}$ granular crystals and $0.2-1.5 \mathrm{~mm}$ acicular crystals). Zeolites were observed in some vesicles. Both pyroxene and plagioclase are elongate and appear to be quench growths.

Sub-unit 4B consists of an aphyric, amygdaloidal, dark-gray basalt. The vesicles $(0.2-1.5 \mathrm{~mm})$ are filled by a light-olive-green clay and calcite. The sub-unit is cut by numerous calcite- and clay-lined veins, normally 1.0 to $2.0 \mathrm{~mm}$ wide, but reaching $2 \mathrm{~cm}$. Lying on top of this unit in the recovery is a fragment of plagioclase phyric basalt; this probably was stoped from a higher unit, because no other material was recovered between subunits 4A and 4B. Thin sections show an intersertal to intergranular texture comprising 10 to 15 per cent plagioclase $\left(\sim \mathrm{An}_{67}\right), 25$ to 30 per cent pinkish clinopyroxene (frequently twinned and zoned), 7.5 per cent titanomagnetite, and 40 to 60 per cent groundmass, containing acicular and feathery microlites. Also observed was 2.5 to 5 per cent basaltic hornblende as anhedral laths or overgrowths on pyroxene. One pyroxene phenocryst was found $(3.5 \times 1.0 \mathrm{~mm})$.

Sub-unit $4 \mathrm{C}$ is separated from sub-unit $4 \mathrm{~B}$ by sediments. The upper part resembles sub-unit $4 \mathrm{~A}$ and grades into material in the lower part resembling sub-unit $4 \mathrm{C}$. This suggests that $4 \mathrm{~A}$ and $4 \mathrm{~B}$ may be parts of the same sill and that $4 \mathrm{C}$ is a smaller, but similar sill.

A K-Ar age determination by McKee and Klock (this volume) yielded a $48.2 \pm 1.0 \mathrm{~m} . \mathrm{y}$. date for sample $446 \mathrm{~A}-11-2,28-31 \mathrm{~cm}$ from this unit.

\section{Unit 5}

The unit starts at the top of core 13 , immediately below unit 4. The unit consists of an aphyric, amygdaloidal $(5 \%, 0.25-2.0 \mathrm{~mm})$, dark-gray basalt, which grades downwards from aphanitic to medium grained and back to fine grained. The vesicles are filled by smectite or calcite. The lower portion contains vesicular $(5 \%$, $0.25-2.0 \mathrm{~mm}$ ) basalt which terminates with a chill zone. Probable pseudomorphs after olivine phenocrysts $(\sim 1$ $\mathrm{mm}$ ) were observed. 


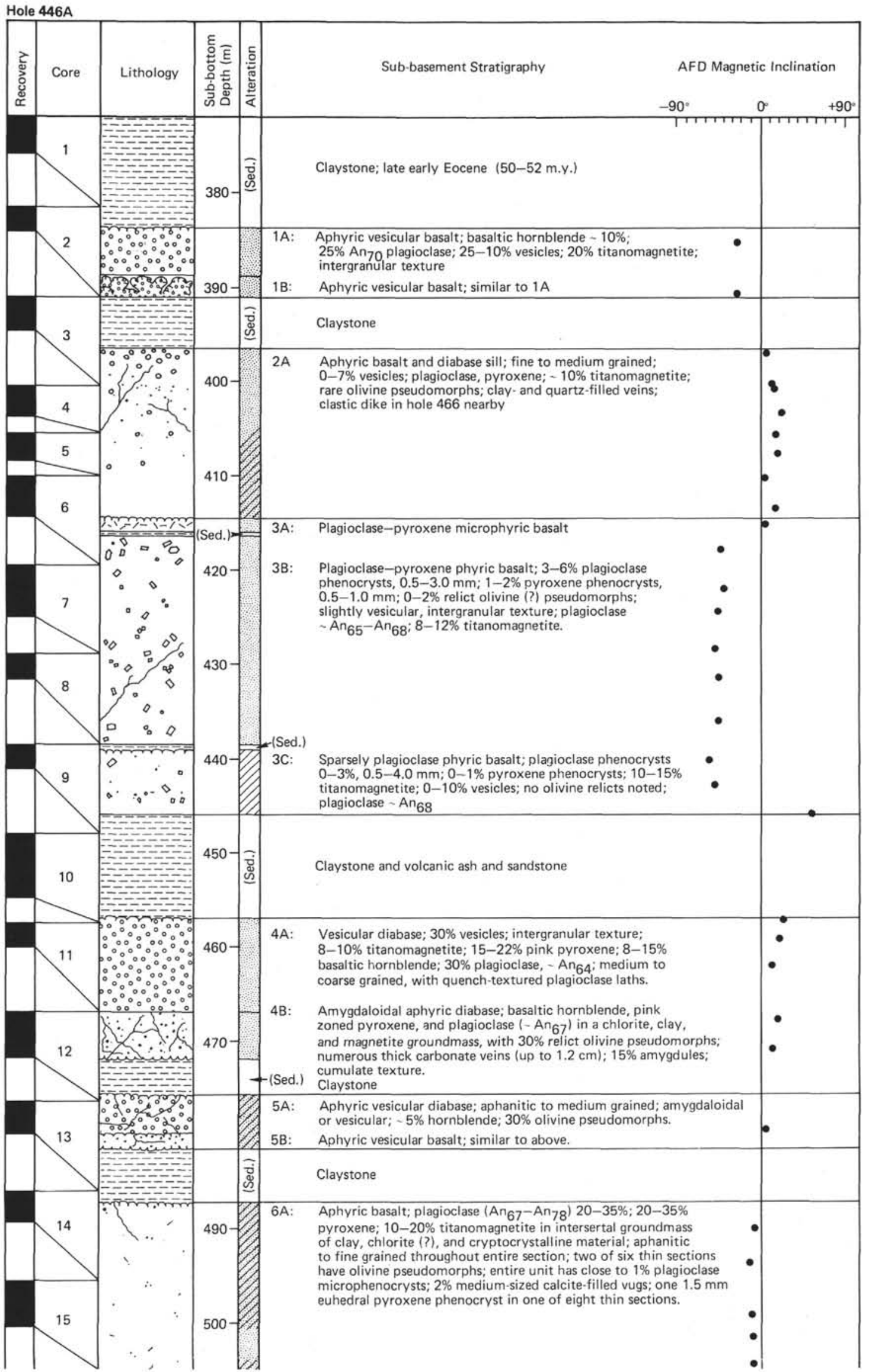

Figure 9. Sub-basement stratigraphy, Hole 446A. 


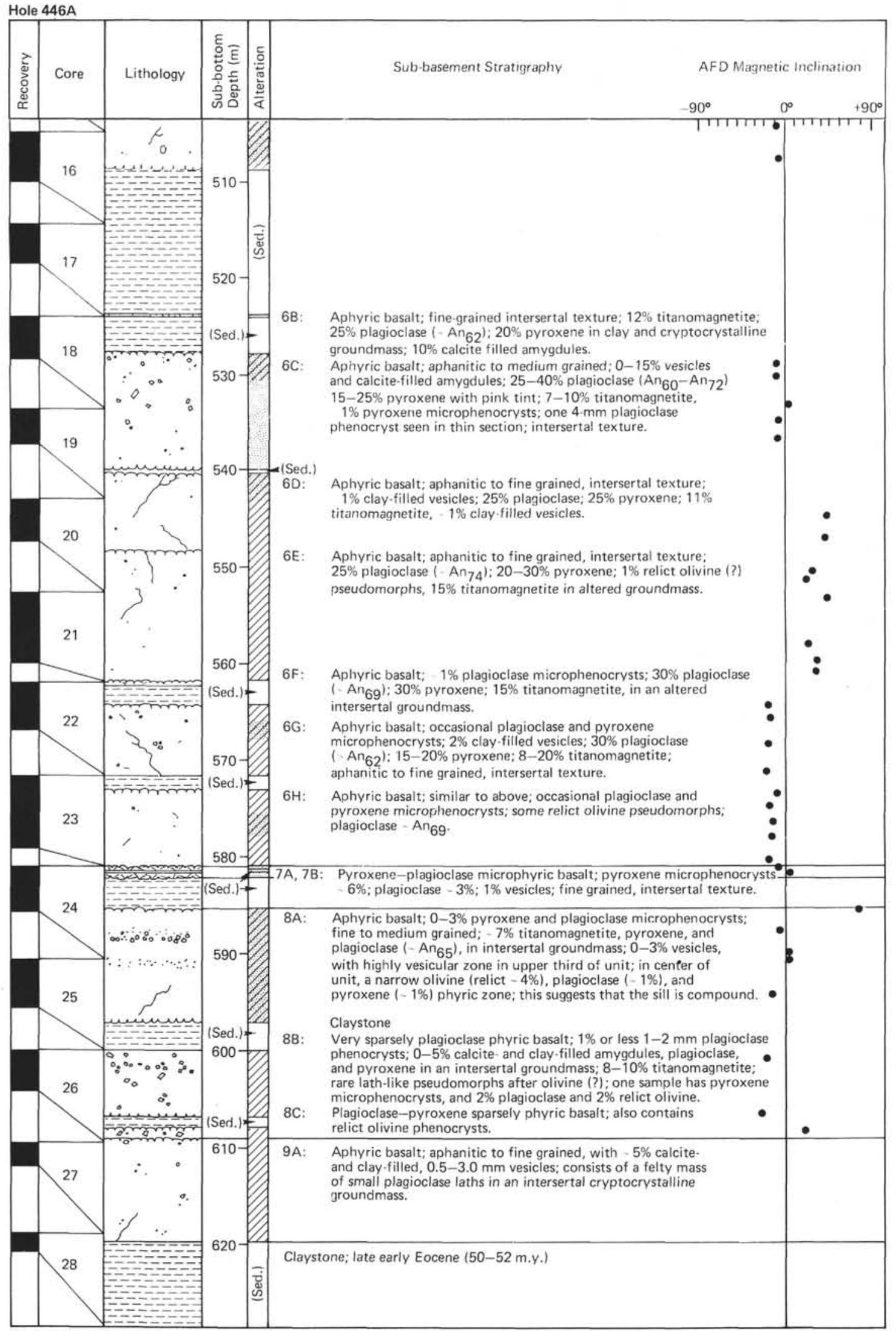

(see Figure 8 for legend)

Figure 9. (Continued). 
The one available thin section indicates a composition of about 15 per cent plagioclase (at least $\mathrm{An}_{58}$ ), 25 per cent pinkish-brown-tinged clinopyroxene, 5 per cent titanomagnetite, and 5 per cent basaltic hornblende (0.02-0.3 $\mathrm{mm}$ as grains, or up to $1 \mathrm{~mm}$ in fibrous forms). The remainder $(\sim 50 \%)$ consists of groundmass, one third of which is brownish, cryptocrystalline clay or talc, and the rest chlorite, usually in euhedral pseudomorphs after olivine $(0.1-1.0 \mathrm{~mm})$. Apatite is an accessory phase.

\section{Unit 6}

These basalts are represented by six sills, ranging in thickness from 7 to 22 meters (Figure 8).

The sills consist of very fine-grained (to aphanitic), aphyric basalts in the upper part of the unit $(6 \mathrm{~A}-6 \mathrm{C})$ and of fine-grained basalts in the lower part (6D-6H). The vesicularity of the basalts ranges from 0 to 5 per cent (and in sill 6C up to 10 or $15 \%$ ), with vesicle diameters up to 2 or $3 \mathrm{~mm}$. The vesicles are filled completely with calcite and zeolites, or calcite and chlorite. The basalts are lightly to moderately altered.

Under the microscope, the basalts from all sills are characterized by similar textures and mineral composition. Sub-units $6 \mathrm{~A}$ to $6 \mathrm{C}$ have a cryptocrystalline texture, which grades into intersertal in the basalt of subunits $6 \mathrm{D}$ to $6 \mathrm{H}$.

The basalts with cryptocrystalline texture contain less than 1 per cent euhedral plagioclase phenocrysts $\left(\mathrm{An}_{55-57}\right), 0.3 \mathrm{~mm}$ long. The groundmass is an aggregate of fine-grained plagioclase and pyroxene.

In a slide from Core 15 , a single olivine crystal was observed which had a diameter of $4 \mathrm{~mm}$. All the basalts have high contents of opaque minerals (up to 10-15\%).

The basalts of intersertal texture have phenocrysts of plagioclase $\left(\mathrm{An}_{55-60}\right)$ up to $0.7 \mathrm{~mm}$ long; these make up 1 per cent of the rock. The groundmass comprises plagioclase $(0.2-0.4 \mathrm{~mm})$, pyroxene $(0.04-0.1 \mathrm{~mm})$, and interstitial glass $(50 \%)$ which is almost completely palagonitized.

Like the basalts of sub-units $6 \mathrm{~A}$ and $6 \mathrm{~B}$, the basalts of sub-units $6 \mathrm{C}, 6 \mathrm{D}$, and $6 \mathrm{E}$ have high opaque-mineral contents (up to $10-15 \%$ ). Many of the feldspar crystals are not twinned and show undulatory extinction.

\section{Unit 7}

The unit is split into two similar sub-units by a claystone interbed. Sub-unit 7A starts at the top of Core 24, Section 1 with a chill zone and glassy rind, and consists of plagioclase phyric basalt (3-4\% plagioclase phenocrysts, $0.5-2 \mathrm{~mm}$ ), possibly with odd relict olivine phenocrysts in the glassy margin $(\sim 1 \mathrm{~mm})$ and rare clayfilled amygdules. Sub-unit 7B starts below the claystone with a chill zone and, apart from the lack of a glassy margin, appears identical to sub-unit 7A.

The only thin section available, from sub-unit $7 a$, contains approximately 5 per cent plagioclase phenocrysts $\left(0.1-1 \mathrm{~mm}\right.$, at least $\left.\mathrm{An}_{60}\right), 5$ per cent pyroxene phenocrysts $(0.1-0.6 \mathrm{~mm}), 2.5$ per cent vesicles (0.05-0.4 mm, filled by a yellowish clay), 7.5 per cent disseminated magnetite, and 80 per cent groundmass showing chloritic alteration and containing microlites of plagioclase $(>0.1 \mathrm{~mm})$ and pyroxene micrograins $(>0.05 \mathrm{~mm})$.

\section{Unit 8}

Two sub-units were recognized, both carrying pseudomorphs after olivine. Sub-unit 8A starts with a chill zone underlying baked sediment; it consists of a finegrained, massive, aphyric basalt with a vesicular zone (Core 24, Section 3, $0 \mathrm{~cm}$ through Core 24, Section 4, $1.5 \mathrm{~cm}$ ) and a zone containing relict olivine (Core 25, Section 1, 0-50 cm). A discontinuity in the sub-unit occurs about a chlorite-lined fracture in Core 25, Section 2,36 to $41 \mathrm{~cm}$. Above the fracture, the basalt is a lighter gray. The basalt in the vicinity of the fracture appears finer grained. In thin section these basalts generally consist of 35 to 45 per cent plagioclase (at least $\mathrm{An}_{64}$ ), 15 to 25 per cent pyroxene (augitic), and 10 to 20 per cent magnetite, with 20 to 40 per cent groundmass. Above the discontinuity, the groundmass shows light-brownish alteration and below dark-greenish alteration.

Sub-unit 8B consists of two sections. The upper section is composed of a very sparsely phyric plagioclase basalt with about 1 per cent vesicles $(\sim 1 \mathrm{~mm})$ filled by calcite and clays with a more-vesicular zone (Core 26 , Section 1, 60-100 cm) having 5 per cent vesicles up to 2 $\mathrm{mm}$ across.

Thin sections show a fine-grained, intersertal texture of about 30 per cent plagioclase microphenocrysts and microlites (at least $\mathrm{An}_{63}$ ), 40 per cent pyroxene (augitic), 10 per cent magnetite, and 20 per cent brownish, altered, cryptocrystalline material. Occasional pyroxene and plagioclase phenocrysts were observed (up to $0.7 \times$ $0.3 \mathrm{~mm}$ ), as were lath-like pseudomorphs of brown chloritic material and calcite after olivine $(3 \times 0.5 \mathrm{~mm}$ in one case). The lower section (sub-unit $8 \mathrm{C}$ ) is finer grained, but otherwise similar to the upper section.

All sub-units of unit 8 are cut by occasional fractures and veins lined by chloritic or clayey material.

\section{Unit 9}

Unit 9 starts with a glassy margin and chill zone adjacent to the base of sub-unit $8 \mathrm{C}$. The unit consists of an aphanitic to very fine-grained, gray basalt with occasional amygdules reaching 10 per cent in the region of Core 27 , Section 1,0 to $110 \mathrm{~cm}$. The amygdules near the top of the unit are filled by calcite and pyrite, lower by clay and pyrite. Odd large vugs, up to 30 by $10 \mathrm{~mm}$ were observed, lined by similar material. Occasional $(<1 \%)$ plagioclase phenocrysts $(0.5-1 \mathrm{~mm})$ occur.

Thin sections show about 30 per cent plagioclase microlites (at least $\mathrm{An}_{60}$ ) and 10 per cent magnetite in a cryptocrystalline groundmass, giving a felty texture.

The unit is cut by occasional calcite- or chlorite- and clay-lined veins, one of the latter being $10 \mathrm{~mm}$ wide.

\section{Summary}

The basalts drilled at Site 446 include rocks with both alkalic and tholeiitic element and petrographic affinities. As a suite, these rocks are very vesicular. Some are clearly unlike any MORB, particularly the horn- 
blende-bearing varieties. All the basalts have incompatible-trace-element concentrations completely unlike MORB. These basalts show closest affinity to alkalic suites typical of ocean islands. High contents of volatiles, including $\mathrm{H}_{2} \mathrm{O}$, are indicated by both the high vesicularity of these basalts and the presence of kaersutite in a number of sills.

\section{PALEOMAGNETISM}

Site 446 is about $100 \mathrm{~km}$ south-southwest of Site 445 on the Daito Ridge. Paleomagnetism samples were taken both from sediments and basalts. NRM and AFdemagnetized NRM were measured in the same manner as described in the previous site reports. NRM stability was examined, as described for Site 445 . Because Site 446 is close to Site 445 , paleomagnetism data from both sites are supplementary and provide an opportunity for testing inter-site reliability. Sample positions in the cores, results of magnetic measurements, and AF demagnetization are listed in Tables 7 and 8 and are shown in Figure 10. In Hole 446A, many basalt sequences were recovered, and paleomagnetism was measured. Stable NRM of basalts is largely scattered, and the NRM inclinations of basalts and adjacent sedimentary interbeds do not show any positive correlation, as shown in Figure 11. It seems likely that almost all the basalt sequences were formed by intrusion after sediment deposition, and that they do not carry the NRM of surrounding sediment. Although the possibility of excursion-type deviation of the geomagnetic field from the geocentric dipole field cannot be ruled out, it is clear that basalt NRM data do not represent the mean geomagnetic field direction at the time of formation of surrounding sediment. Therefore, only sediment NRM data will be used hereafter for analyses. After careful examination, only 28 samples for Hole 446 and 12 for Hole 446A were found to be reliable. Most of the samples taken from unconsolidated sediments and coarse-grained mudstone layers were not stable; therefore, the stable NRM absolute inclination values are not homogeneously distributed with depth, but concentrated between 150 and 600 meters sub-bottom (Figure 12). According to shipboard paleontological study, this layer was formed during the Eocene. Using the method described for Site 445 , an average value of absolute inclination is calculated for the Eocene, giving the following figures:

\begin{tabular}{lccc}
\hline Hole & $\begin{array}{c}\text { Number of } \\
\text { Stable-NRM } \\
\text { Measurements }\end{array}$ & $\begin{array}{c}\text { Mean } \\
\text { (degrees) }\end{array}$ & $\begin{array}{c}\text { Standard Deviation } \\
\text { (degrees) }\end{array}$ \\
\hline 446 & 28 & 12.3 & 9.0 \\
$446 \mathrm{~A}$ & 12 & 8.6 & 5.8 \\
\hline
\end{tabular}

Therefore, the latitudes for Holes 446 and 446A during the Eocene are calculated as $6.2 \pm 4.5$ (446) and $4.3 \pm 3.0(446 \mathrm{~A})$ degrees north or south, respectively.

These values are plotted in addition to points for other sites in Figure 13. They reveal good agreement between paleomagnetism results for Site 445 and 446 . Consistency of paleomagnetism data among various sites in the same lithospheric plate, with sediments of
TABLE 7

Paleomagnetism Measurements of Sedimentary Cores of Site $446^{a}$

\begin{tabular}{|c|c|c|c|c|c|c|}
\hline \multirow{2}{*}{$\begin{array}{c}\text { Sample } \\
\text { (interval in } \mathrm{cm} \text { ) }\end{array}$} & \multirow{2}{*}{$\begin{array}{l}\text { Sub-Bottom } \\
\text { Depth } \\
\text { (m) }\end{array}$} & \multirow{2}{*}{$\begin{array}{l}J_{\text {NRM }} \\
\left(10^{-5}\right. \\
\text { gauss) }\end{array}$} & \multirow{2}{*}{$\begin{array}{c}\text { Suscepti- } \\
\text { bility } \\
\left(10^{-5}\right. \\
\text { gauss/oe) }\end{array}$} & \multicolumn{2}{|c|}{ Inclination } & \\
\hline & & & & NRM & AFD & ity \\
\hline $446-2-1,65-67$ & 2.16 & 0.99 & 0.44 & -27.9 & -32.0 & - \\
\hline $3-3,120-122$ & 15.21 & 0.33 & 0.60 & 30.9 & 17.5 & + \\
\hline $3-4,120-122$ & 16.71 & 0.67 & 0.60 & -37.5 & -67.7 & - \\
\hline $3-5,3-5$ & 17.04 & 0.56 & 0.56 & 29.6 & 27.6 & + \\
\hline $5-4,94-96$ & 35.46 & 0.12 & 0.50 & 70.0 & -27.5 & $+1-$ \\
\hline $5-5,94-96$ & 36.95 & 1.59 & 0.56 & -38.1 & -44.4 & - \\
\hline $5 \cdot 6,94-96$ & 38.45 & 0.26 & 0.41 & -39.0 & -50.0 & - \\
\hline $6-5,42-44$ & 45.93 & 2.81 & 0.58 & 47.2 & 49.4 & + \\
\hline $7-1,91-93$ & 49.92 & 9.81 & 0.59 & -14.9 & -15.8 & - \\
\hline $7-2,91-93$ & 51.42 & 0.36 & 0.78 & -16.5 & -66.4 & - \\
\hline $7-3,91-93$ & 52.92 & 1.20 & 0.67 & 14.3 & -5.4 & $+1-$ \\
\hline $7-4,91-93$ & 54.42 & 2.10 & 0.47 & -33.7 & -37.4 & - \\
\hline $7-5,91-93$ & 55.92 & 0.81 & 0.44 & -26.8 & 2.4 & $-1+$ \\
\hline $8-1,29-31$ & 58.80 & 2.53 & 0.67 & -32.2 & -31.0 & - \\
\hline $8-5,51-53$ & 65.02 & 1.76 & 0.66 & -9.2 & -0.7 & - \\
\hline $8, \mathrm{CC}, 10-12$ & 67.61 & 0.70 & 0.52 & -2.2 & 36.4 & $-1+$ \\
\hline $\begin{array}{l}9-1,74-76 \\
9-2,97-99\end{array}$ & 68.75 & 0.043 & - & -26.9 & - & \\
\hline $9-2,97-99$ & 70.49 & 0.034 & 0.42 & -55.3 & -60.3 & - \\
\hline $9-3,21-23$ & 71.22 & 0.56 & 0.41 & -25.6 & -85.6 & - \\
\hline $9-4,5-7$ & 72.56 & 1.06 & 0.47 & -53.6 & -86.7 & - \\
\hline $9-5,57-59$ & 74.59 & 2.32 & 0.52 & 3.1 & -1.1 & $+1-$ \\
\hline $10-6,106-108$ & 86.07 & 1.96 & 0.50 & -17.2 & -22.7 & - \\
\hline $10-7,29-31$ & 86.80 & 0.97 & 0.36 & -55.7 & -52.2 & - \\
\hline $11-1,25-27$ & 87.26 & 0.77 & 0.44 & -33.7 & -67.8 & - \\
\hline $11 \cdot 2,66-68$ & 89.17 & 0.98 & 1.01 & -56.4 & -65.0 & - \\
\hline $11-3,25-27$ & 90.26 & 0.89 & 0.44 & -3.4 & -63.5 & $\bar{t}$ \\
\hline $11-4,25-27$ & 91.76 & 1.43 & 0.42 & 14.7 & 24.7 & + \\
\hline $12-1,130-132$ & 97.81 & 1.15 & 0.46 & -3.8 & -56.8 & - \\
\hline $12-2,105-107$ & 99.06 & 0.77 & 0.45 & -10.5 & -75.5 & - \\
\hline $12-3,105-107$ & 100.56 & 0.70 & 0.44 & -70.5 & -58.3 & - \\
\hline $12-4,55-57$ & 101.56 & 1.78 & 0.53 & -1.0 & & $-1+$ \\
\hline $13-1,116-118$ & 107.17 & 1.18 & 0.42 & -52.4 & -77.0 & - \\
\hline $13-2,32-34$ & 108.83 & 1.44 & 0.66 & 0.8 & -9.5 & $-1+$ \\
\hline $13-3,115-117$ & 110.16 & 4.17 & 1.31 & 0.2 & -4.2 & $+1-$ \\
\hline $14-1,140-142$ & 116.91 & 0.33 & 0.54 & 81.1 & 43.6 & - \\
\hline $14-2,61-63$ & 117.62 & 1.21 & 0.54 & -43.5 & -16.7 & - \\
\hline $14-3,61-63$ & 119.12 & 0.02 & 0.61 & -45.5 & -35.0 & - \\
\hline $14-4,61-63$ & 120.62 & 1.12 & 1.10 & -4.7 & -34.0 & - \\
\hline $14-5,61-63$ & 122.12 & 5.49 & 1.15 & 22.7 & 27.0 & + \\
\hline $15-2,123-125$ & 127.74 & 2.33 & 1.41 & -34.6 & -24.2 & - \\
\hline $15-3,123-125$ & 129.24 & 4.83 & 1.30 & -28.2 & -19.0 & $\overline{4}$ \\
\hline $16-2,38-40$ & 136.39 & 0.88 & 1.14 & 12.2 & -31.9 & $+1-$ \\
\hline $16-3,122-124$ & 138.73 & 7.51 & 0.84 & 19.3 & 19.0 & + \\
\hline $16-4,38-40$ & 139.39 & 4.51 & 1.04 & -22.4 & -27.1 & - \\
\hline $21-1,88-90$ & 182.89 & 4.72 & 1.59 & 43.4 & 44.5 & + \\
\hline $21-2,88-90$ & 184.39 & 2.57 & 3.15 & -44.7 & -53.2 & - \\
\hline $23-1,55-57$ & 201.56 & 12.94 & 2.24 & 26.7 & 29.7 & + \\
\hline $23-2,55-57$ & 203.06 & 9.25 & 1.42 & 31.6 & 31.2 & \\
\hline $23-3,8-10$ & 204.09 & 3.48 & 2.60 & -23.3 & -21.9 & - \\
\hline $24-1$ & 210.50 & 2.40 & 2.63 & -23.4 & -0.3 & - \\
\hline $24-3,126-128$ & 214.77 & 7.98 & 2.29 & 13.1 & 18.9 & + \\
\hline $25 \cdot 2,87-89$ & 222.38 & 22.50 & 3.13 & 15.5 & 15.5 & + \\
\hline $25-3,61-63$ & 223.62 & 66.57 & 1.64 & -5.3 & -5.9 & - \\
\hline $26-1,43-45$ & 229.94 & 13.74 & 1.24 & -31.3 & -31.9 & - \\
\hline $26-2,109-111$ & 232.10 & 17.38 & 0.73 & -20.3 & -20.5 & - \\
\hline $26-3,129-131$ & 253.80 & 36.10 & 1.81 & 55.4 & 56.9 & + \\
\hline $27-1,142-144$ & 240.43 & 15.10 & 1.08 & 10.0 & 12.1 & + \\
\hline $27-2,115-117$ & 241.66 & 13.35 & 0.95 & 45.6 & 46.8 & + \\
\hline $28-1,76-78$ & 249.27 & 6.44 & 2.81 & 35.8 & 39.1 & + \\
\hline $29-1,28-30$ & 258,29 & 34.35 & 2.07 & 10.5 & 9.5 & + \\
\hline $30-1,54-56$ & 268.05 & 5.14 & 1.90 & 8.7 & 8.8 & + \\
\hline $30-2,126-128$ & 270.27 & 6.87 & 2.20 & 11.7 & 8.7 & + \\
\hline $30-3,104-106$ & 271.55 & 6.37 & 3.37 & 8.8 & 11.8 & + \\
\hline $31-1,7-9$ & 277.08 & 12.88 & 2.42 & -13.6 & -12.8 & - \\
\hline $31-3,88-90$ & 280.89 & 0.25 & 1.08 & -2.6 & -9.9 & - \\
\hline $31, \mathrm{CC}, 13-15$ & 286.14 & 9.41 & 1.73 & 32.7 & 34.1 & + \\
\hline $32-2,98-100$ & 288.99 & 33.07 & 2.78 & 14.7 & 14.6 & + \\
\hline $32-3,116-118$ & 290.67 & 9.62 & 2.61 & -5.3 & -4.0 & - \\
\hline $32-4,49-51$ & 291.50 & 16.73 & 1.37 & 6.2 & 5.9 & + \\
\hline $32-5,124-126$ & 293.75 & 13.92 & 3.68 & 32.0 & 41.0 & + \\
\hline $33-1,126-128$ & 297.27 & 34.98 & 1.73 & -37.9 & -38.7 & - \\
\hline $34-1,35-37$ & 305.86 & 36.01 & 1.99 & 23.4 & 21.7 & + \\
\hline $34-2,123-125$ & 308.24 & 19.76 & 2.73 & 0.1 & 2.4 & + \\
\hline $34-3,40-42$ & 308.91 & 43.91 & 1.90 & 13.8 & 14.2 & + \\
\hline $34-4,11-13$ & 310.12 & 56.55 & 1.34 & 8.7 & 8.7 & + \\
\hline $34-6,48-50$ & 313.49 & 25.54 & 2.03 & 5.8 & 5.1 & + \\
\hline $35, \mathrm{CC}$ & 324.00 & 23.72 & 3.00 & 4.5 & 5.9 & + \\
\hline $36-1,142-144$ & 325.93 & 9.54 & 1.45 & 0.8 & -0.4 & $+1-$ \\
\hline $36-2,98-100$ & 326.99 & 1.14 & 0.39 & 4.7 & 5.0 & + \\
\hline
\end{tabular}


TABLE 7 - Continued

\begin{tabular}{|c|c|c|c|c|c|c|}
\hline \multirow{2}{*}{$\begin{array}{c}\text { Sample } \\
\text { (interval in } \mathrm{cm} \text { ) }\end{array}$} & \multirow{2}{*}{$\begin{array}{l}\text { Sub-Bottom } \\
\text { Depth } \\
\text { (m) }\end{array}$} & \multirow{2}{*}{$\begin{array}{l}J_{\mathrm{NRM}} \\
\left(10^{-5}\right. \\
\text { gauss })\end{array}$} & \multirow{2}{*}{$\begin{array}{l}\text { Suscepti- } \\
\text { bility } \\
\left(10^{-5}\right. \\
\text { gauss/oc) }\end{array}$} & \multicolumn{2}{|c|}{ Inclination } & \multirow{2}{*}{$\begin{array}{l}\text { Polar- } \\
\text { ity }\end{array}$} \\
\hline & & & & NRM & $\mathrm{AlD}$ & \\
\hline $446-36-3,107-109$ & 328.58 & 10.31 & 1.88 & -2.9 & -3.3 & \\
\hline $\begin{array}{l}37-1,125-127 \\
38-1,12-14 \\
38-3,132-134 \\
38-4,120-122 \\
38-6,62-64\end{array}$ & $\begin{array}{l}335.26 \\
343.63 \\
347.83 \\
349.21 \\
351.63\end{array}$ & $\begin{array}{l}4.17 \\
34.16 \\
30.97 \\
25.93 \\
78.6\end{array}$ & $\begin{array}{l}2.53 \\
2.77 \\
3.11 \\
2.63 \\
2.13\end{array}$ & $\begin{array}{r}4.6 \\
1.5 \\
18.2 \\
-4.4 \\
-0.4\end{array}$ & $\begin{array}{r}6.5 \\
0.7 \\
18.8 \\
-5.2 \\
-1.0\end{array}$ & $\begin{array}{l}+ \\
+ \\
+ \\
+ \\
-\end{array}$ \\
\hline $\begin{array}{l}39-1,26-28 \\
39-3,7-9 \\
40-1,59-61 \\
41-1,122-124 \\
41-2,17-19\end{array}$ & $\begin{array}{l}353.27 \\
356.08 \\
363.10 \\
373.22 \\
373.68\end{array}$ & $\begin{array}{l}50.2 \\
2.66 \\
5.77 \\
3.14 \\
8.88\end{array}$ & $\begin{array}{l}2.07 \\
1.17 \\
0.38 \\
0.64 \\
0.43\end{array}$ & $\begin{array}{r}11.6 \\
-14.3 \\
-14.0 \\
27.0 \\
36.8\end{array}$ & $\begin{array}{r}12.0 \\
-12.0 \\
-16.8 \\
17.3 \\
34.7\end{array}$ & $\begin{array}{l}+ \\
- \\
+ \\
+\end{array}$ \\
\hline $\begin{array}{l}41-3,120-122 \\
43-1,127-129 \\
43-2,97-99 \\
43-3,118-120\end{array}$ & $\begin{array}{l}376.21 \\
392.29 \\
393.48 \\
395.19\end{array}$ & $\begin{array}{r}7.13 \\
4.02 \\
11.74 \\
17.23\end{array}$ & $\begin{array}{l}0.75 \\
0.39 \\
0.43 \\
0.78\end{array}$ & $\begin{array}{l}-9.7 \\
20.1 \\
-1.0 \\
23.3\end{array}$ & $\begin{array}{r}-13.5 \\
19.9 \\
-1.8 \\
22.7\end{array}$ & $\begin{array}{l}\overline{+} \\
+ \\
+\end{array}$ \\
\hline $\begin{array}{c}446 \mathrm{~A}-1-2,7-9 \\
1-3,8-9 \\
3-1,110-112 \\
10-1,42-44 \\
10-3,115-117\end{array}$ & $\begin{array}{l}373.56 \\
375.07 \\
392.11 \\
448.43 \\
452.16\end{array}$ & $\begin{array}{l}3.15 \\
0.005 \\
6.44 \\
6.57 \\
1.71\end{array}$ & $\begin{array}{l}0.52 \\
0.24 \\
0.52 \\
0.57 \\
0.57\end{array}$ & $\begin{array}{r}19.0 \\
1.8 \\
27.1 \\
8.3 \\
28.9\end{array}$ & $\begin{array}{r}14.6 \\
-1.7 \\
25.1 \\
6.5 \\
20.7\end{array}$ & $\begin{array}{l}+ \\
+1- \\
+ \\
+ \\
+\end{array}$ \\
\hline $\begin{array}{l}10-5,50-52 \\
12-3,101-103 \\
13-3,73-75 \\
16-4,128-130 \\
17-1,77-79\end{array}$ & $\begin{array}{l}454.51 \\
471.02 \\
480.24 \\
510.79 \\
515.28\end{array}$ & $\begin{array}{l}3.56 \\
4.54 \\
2.77 \\
1.03 \\
0.69\end{array}$ & $\begin{array}{l}0.56 \\
0.43 \\
0.49 \\
0.40 \\
0.30\end{array}$ & $\begin{array}{r}32.5 \\
0.0 \\
14.1 \\
9.8 \\
2.8\end{array}$ & $\begin{array}{r}27.2 \\
-2.9 \\
9.1 \\
15.5 \\
-1.7\end{array}$ & $\begin{array}{l}+ \\
+ \\
+ \\
+1-\end{array}$ \\
\hline $\begin{array}{l}17-3,50-52 \\
18-1,107-109 \\
18-2,27-29 \\
19-3,22-24 \\
22-1,104-106\end{array}$ & $\begin{array}{l}518.01 \\
525.06 \\
525.78 \\
536.73 \\
563.05\end{array}$ & $\begin{array}{r}8.68 \\
11.10 \\
63.72 \\
37.43 \\
26.59\end{array}$ & $\begin{array}{l}1.04 \\
0.87 \\
4.19 \\
2.64 \\
4.54\end{array}$ & $\begin{array}{r}13.5 \\
-14.8 \\
-10.6 \\
-11.4 \\
0.1\end{array}$ & $\begin{array}{r}13.4 \\
-19.4 \\
-12.4 \\
-11.6 \\
0.7\end{array}$ & + \\
\hline $\begin{array}{l}23-1,64-66 \\
24-1,117-119 \\
24-2,28-30 \\
25-3,97-99 \\
25-4,62-64 \\
26-3,59-61\end{array}$ & $\begin{array}{l}572.15 \\
582.16 \\
582.79 \\
594.48 \\
595.63 \\
603.60\end{array}$ & $\begin{array}{r}43.06 \\
200.39 \\
122.11 \\
67.80 \\
66.77 \\
3.57\end{array}$ & $\begin{array}{l}4.30 \\
7.04 \\
7.95 \\
4.80 \\
3.65 \\
0.87\end{array}$ & $\begin{array}{r}11.7 \\
6.8 \\
-0.1 \\
0.2 \\
-7.5 \\
5.9\end{array}$ & $\begin{array}{r}12.3 \\
7.2 \\
1.1 \\
-0.3 \\
-8.7 \\
7.8\end{array}$ & $\begin{array}{l}+ \\
+ \\
+\end{array}$ \\
\hline
\end{tabular}

aAFD is obtained by peak alternating demagnetizing field of 150 oe, decreasing to zero at a constant rate of 20 milligauss/cycle; polarity shows whether the inclination of NRM is positive $(+)$ or negative $(-)$.

different lithologies, indicates that these results are significant. The gradual changes in magnetic inclination with age are in good agreement with those obtained for DSDP samples from the west Philippine Basin (Site 292) by Louden (1977). This implies that the Daito Ridge and Basin province has been drifting northward at an almost constant rate (minimum $4 \mathrm{~cm} / \mathrm{yr}$ ) for the last $50 \mathrm{~m} . \mathrm{y}$., in conjunction with the west Philippine Basin.

\section{PHYSICAL PROPERTIES}

Physical-properties measurements for sediments recovered from Holes 446 and 446A included shear strength, sonic velocity, thermal conductivity, wet-bulk density, water content, and porosity (Table 9). Values for wetbulk density, grain density, thermal conductivity, and sonic velocity for basalts are given in Table 10. Special 2-minute GRAPE counts for basalts are summarized in Table 11 . A grain density of $3.034 \mathrm{~g} / \mathrm{cm}^{3}$ was assumed for the 2-minute-GRAPE calculations.

The variation of sediment shear strength with depth is presented in Figure 14. Although there is considerable scatter in the data, there is a tendency for the average values of shear strength to increase with depth. A similar increase of shear strength with depth was observed for clays and muds of Sites 442,443 , and 444 , but the increase at these sites began 80 meters below the
TABLE 8

Paleomagnetism of Basalts, Site $446^{\mathrm{a}}$

\begin{tabular}{|c|c|c|c|c|c|c|c|c|}
\hline \multirow{2}{*}{$\begin{array}{c}\text { Sample } \\
\text { (interval in } \mathrm{cm} \text { ) }\end{array}$} & \multirow{2}{*}{$\begin{array}{l}\text { Sub-Bottom } \\
\text { Depth } \\
\text { (m) }\end{array}$} & \multirow{2}{*}{$\begin{array}{l}J_{\text {NRM }} \\
\left(10^{-5}\right. \\
\text { gauss }\end{array}$} & \multicolumn{2}{|c|}{ Inclination } & \multirow{2}{*}{$\begin{array}{c}\text { MDF } \\
\text { (oe) }\end{array}$} & \multirow{2}{*}{$\begin{array}{c}X_{\text {in }} \\
110^{-5} \\
\text { gauss/oe }\end{array}$} & \multirow[b]{2}{*}{$Q_{n}^{t}$} & \multirow{2}{*}{$\begin{array}{c}\text { Remark } \\
(\mathrm{oe})\end{array}$} \\
\hline & & & NRM & AFD & & & & \\
\hline $\begin{array}{l}446-41, \mathrm{CC}, 19-21 \\
44-1,-2\end{array}$ & $\begin{array}{l}381.2 \\
40056\end{array}$ & 85.66 & -55.7 & -17.1 & $\begin{array}{c}150 \\
75\end{array}$ & $\begin{array}{l}11.60 \\
19.39\end{array}$ & 17,6 & $\begin{array}{l}200 \\
100\end{array}$ \\
\hline $44-2,49-51$ & $\begin{array}{l}\begin{array}{l}4400.56 \\
402.50\end{array} \\
-\end{array}$ & 2004.7 & $\begin{array}{l}10.1 \\
15.7\end{array}$ & $\begin{array}{l}13.6 \\
18.0\end{array}$ & $\begin{array}{l}75 \\
75\end{array}$ & $\begin{array}{r}19.39 \\
9.78\end{array}$ & $\begin{array}{r}97.4 \\
488.5\end{array}$ & $\begin{array}{l}100 \\
100\end{array}$ \\
\hline $43-4,21-23$ & 395.70 & 1084.1 & 16.1 & 24.6 & 120 & 6.53 & 395.6 & 150 \\
\hline $46-1,47-49$ & 419.90 & 1209.3 & -49.1 & -51.3 & 130 & 10.85 & 265.6 & 150 \\
\hline $\begin{array}{c}446 \mathrm{~A}-2-1,1,145-147 \\
2 \cdot 3-3143\end{array}$ & $\begin{array}{l}382.96 \\
334.92\end{array}$ & $\begin{array}{r}348.69 \\
523429\end{array}$ & $\begin{array}{l}-35.6 \\
-241\end{array}$ & & & 9.2 & $\begin{array}{r}90.3 \\
9596\end{array}$ & $\begin{array}{l}200 \\
200\end{array}$ \\
\hline $\begin{array}{l}2-3,41-343 \\
3-3,50-52\end{array}$ & $\begin{array}{l}394.92 \\
394.51\end{array}$ & $\begin{array}{r}5232.49 \\
744.88\end{array}$ & $\begin{array}{r}-24.1 \\
-4.6\end{array}$ & $\begin{aligned}-25.2 \\
5.2\end{aligned}$ & $\begin{array}{r}155 \\
70\end{array}$ & $\begin{array}{l}13.0 \\
11.2\end{array}$ & $\begin{array}{l}959.6 \\
158.5\end{array}$ & $\begin{array}{l}200 \\
100\end{array}$ \\
\hline $3-4,34-36$ & & 81.56 & 2.3 & 13.5 & 80 & 13.4 & 14.5 & 100 \\
\hline $4-1,32-34$ & & 667.97 & 7.1 & 15.5 & 90 & 14.5 & 109.8 & 100 \\
\hline $\begin{array}{l}\begin{array}{l}4-2,44-46 \\
4-3,43-45\end{array} \\
4\end{array}$ & $\begin{array}{l}401.95 \\
403.94\end{array}$ & $\begin{array}{r}399.24 \\
1156.96\end{array}$ & $\begin{array}{r}5.4 \\
14.2\end{array}$ & $\begin{array}{l}23.1 \\
17.6\end{array}$ & $\begin{array}{r}120 \\
90\end{array}$ & $\begin{array}{l}11.7 \\
13.0\end{array}$ & $\begin{array}{r}81.3 \\
212.1\end{array}$ & $\begin{array}{l}150 \\
100\end{array}$ \\
\hline S-1, 16-18 & 55.67 & $\begin{array}{r}1156.96 \\
550.71\end{array}$ & $\begin{array}{r}14.2 \\
9.0\end{array}$ & $\begin{array}{l}1.6 \\
21.2\end{array}$ & - & $\begin{array}{l}11.0 \\
11.0\end{array}$ & $\begin{array}{l}112.1 \\
119.3\end{array}$ & 200 \\
\hline $5-2,24-26$ & 07.23 & 590.12 & -2.1 & 17.6 & 110 & 12.5 & 112.5 & 150 \\
\hline $6-1,10-12$ & 410.11 & 474.41 & -17.8 & 3.6 & 40 & 12.8 & 88.3 & so \\
\hline $6-2,38-40$ & $\begin{array}{l}411.89 \\
412.69\end{array}$ & $\begin{array}{r}970.36 \\
291734\end{array}$ & $\begin{array}{l}10.6 \\
-52\end{array}$ & $\begin{array}{r}16.0 \\
1.7\end{array}$ & $\begin{array}{r}120 \\
90\end{array}$ & $\begin{array}{r}13.6 \\
9.3\end{array}$ & $\begin{array}{l}170.1 \\
747.5\end{array}$ & $\begin{array}{l}150 \\
100\end{array}$ \\
\hline $\begin{array}{l}6-2,11 \\
6-3,10\end{array}$ & $\begin{array}{l}9 \\
0\end{array}$ & $\begin{array}{l}2911.74 \\
1547.11\end{array}$ & $\begin{array}{l}-5.2 \\
-44.3\end{array}$ & $\begin{array}{r}1.7 \\
-43.1\end{array}$ & $\begin{array}{r}90 \\
110\end{array}$ & $\begin{array}{r}9.3 \\
11.6\end{array}$ & $\begin{array}{l}\text { 747.5. } \\
317.9\end{array}$ & $\begin{array}{l}100 \\
150\end{array}$ \\
\hline $7-2,24-$ & & 447.46 & -43.7 & -39.2 & 90 & 13.8 & 77.3 & 100 \\
\hline $7-3,38-40$ & & 672.58 & -39.5 & -45.3 & 95 & 10.9 & 147.1 & 100 \\
\hline $\begin{array}{l}7-4,138-140 \\
8-1,75-77\end{array}$ & $\begin{array}{l}425.39 \\
429.76\end{array}$ & $\begin{array}{l}833.75 \\
820.48\end{array}$ & $\begin{array}{l}-48.8 \\
-40.9\end{array}$ & $\begin{array}{l}-49.1 \\
-44.5\end{array}$ & $\begin{array}{l}100 \\
115\end{array}$ & $\begin{array}{l}12.5 \\
11.1\end{array}$ & $\begin{array}{l}159.0 \\
176.2\end{array}$ & $\begin{array}{l}100 \\
150\end{array}$ \\
\hline $8-2,72-74$ & & $\begin{array}{l}866.22 \\
466.40\end{array}$ & -48.8 & -45.1 & 80 & 12.4 & 89.6 & 100 \\
\hline & & & -53.8 & -53.2 & 80 & 14.4 & 102.6 & 100 \\
\hline $9-2,54-56$ & 440.55 & 352.75 & -60.9 & -49.2 & 110 & is.1 & 55.7 & 150 \\
\hline $9-3,51-5$ & 442.02 & $\begin{array}{r}446.08 \\
46.75\end{array}$ & 56.7 & 53.6 & 85 & 13.5 & & \\
\hline & & & $\begin{array}{l}23.0 \\
16.2\end{array}$ & 0.7 & $\begin{array}{l}90 \\
75\end{array}$ & & 6.0 & $\begin{array}{l}00 \\
00\end{array}$ \\
\hline & & & 11.4 & & 75 & & & 00 \\
\hline $12 \cdot 1,53-53$ & 467.54 & 59.80 & -30.5 & 1.8 & 35 & 14.8 & 9.6 & 50 \\
\hline $12-1,53-5$ & 469.20 & & $\overline{-8.1}$ & 19.8 & 60 & & & $\begin{array}{l}50 \\
00\end{array}$ \\
\hline & ${ }^{469.20}$ & 180 & -8.1 & $\begin{array}{l}11.5 \\
14.8\end{array}$ & 60 & 18.4 & 23,4 & \\
\hline & 477.56 & 228.08 & -3.0 & 4.8 & 155 & 10.3 & 52.8 & 00 \\
\hline $14-1,102-10$ & 487.03 & 41.41 & -50.4 & -38.7 & 45 & 19.3 & 5.1 & \\
\hline $\begin{array}{l}14-1,102-104 \\
14-2,44-46\end{array}$ & 487.95 & & -9.8 & $\begin{array}{r}+19.0 \\
-5.6\end{array}$ & & & & $\begin{array}{l}50 \\
50\end{array}$ \\
\hline & & 06 & $\begin{array}{r}-13.5 \\
-13.5\end{array}$ & -10.5 & 90 & 6.1 & $\begin{array}{l}83.1 \\
53.4\end{array}$ & 00 \\
\hline & & & & & & & & \\
\hline $\begin{array}{l}15-3, \\
15-4\end{array}$ & & $\begin{array}{l}290.51 \\
331.11\end{array}$ & $\begin{array}{r}-10.9 \\
-7.6\end{array}$ & & $\begin{array}{r}110 \\
75\end{array}$ & & & \\
\hline & & $\begin{array}{l}260.78 \\
260.11\end{array}$ & $\begin{array}{l}-1.6 \\
-26.4\end{array}$ & $\begin{array}{l}-1.8 \\
-8.8\end{array}$ & $\begin{array}{l}75 \\
60\end{array}$ & & & \\
\hline & & & -4 & & 130 & & & \\
\hline & $\begin{array}{l}527.84 \\
528.74\end{array}$ & & $\begin{array}{r}-10.9 \\
1.8\end{array}$ & $\begin{array}{l}-7.5 \\
-7.3\end{array}$ & & & $\begin{array}{l}57.5 \\
37.7\end{array}$ & \\
\hline & & $\begin{array}{l}213.46 \\
224.62\end{array}$ & $\begin{array}{l}1.8 \\
9.9\end{array}$ & 4.3 & $\begin{array}{l}80 \\
40\end{array}$ & & & \\
\hline & & & $\begin{array}{l}-2.5 \\
-2.5\end{array}$ & & 105 & & & \\
\hline & & & & & 75 & & & \\
\hline & & & & & & & & \\
\hline$\frac{1}{2}$ & & & & $\begin{array}{l}29.9 \\
44.2\end{array}$ & $\begin{array}{l}130 \\
120\end{array}$ & & & \\
\hline & & & & & 95 & & & \\
\hline & & & & & 140 & & 68.2 & \\
\hline & & & & & & & & \\
\hline $\begin{array}{l}23-4,44- \\
23-5,37\end{array}$ & & $\begin{array}{l}165.35 \\
151.41\end{array}$ & $\begin{array}{l}-14.8 \\
-18.0\end{array}$ & & $\begin{array}{l}65 \\
50\end{array}$ & & & \\
\hline & & & -27 & & & & & \\
\hline & & & -2 & -4 & & & & \\
\hline & & & & & $\begin{array}{c}155 \\
50\end{array}$ & & & \\
\hline 2 & & 197.91 & 47.0 & & 50 & & - & \\
\hline & & & 1.0 & & & & & \\
\hline & & & & & 105 & & & \\
\hline & & & $\begin{array}{r}-9.6 \\
-23.3\end{array}$ & & $\begin{array}{l}85 \\
50\end{array}$ & $\begin{array}{l}22.0 \\
25.1\end{array}$ & & \\
\hline $\begin{array}{l}25-2,69 \\
20-4,35\end{array}$ & & 151.93 & -23.3 & & & & & \\
\hline & & & & & & & & \\
\hline $128-130$ & & & & & & & & \\
\hline $1-4,61-63$ & $\begin{array}{l}555.5 \\
557.62\end{array}$ & $\begin{array}{l}130.94 \\
162.67\end{array}$ & $\begin{array}{l}34.5 \\
15.7\end{array}$ & $\begin{array}{l}34.6 \\
26.9\end{array}$ & $\begin{array}{r}130 \\
80\end{array}$ & $\begin{array}{l}14.0 \\
15.0\end{array}$ & $\begin{array}{l}22.3 \\
25.8\end{array}$ & \\
\hline (1) & & & 15.7 & 36.3 & 140 & & & \\
\hline & & & & & & & & \\
\hline & & & $\begin{array}{l}-14 . \\
-16\end{array}$ & & 13 & & & \\
\hline $22-3,80-82$ & $\begin{array}{l}564.26 \\
565.81\end{array}$ & $\begin{array}{l}594.35 \\
732.47\end{array}$ & $\begin{array}{l}-16.2 \\
-14.2\end{array}$ & $\begin{array}{l}-12.5 \\
-16.5\end{array}$ & $\begin{array}{r}115 \\
95\end{array}$ & $\begin{array}{l}22.2 \\
20.2\end{array}$ & $\begin{array}{l}6.3 .8 \\
86.4\end{array}$ & \\
\hline & & & -20.2 & & 120 & & & \\
\hline & & & & & & & & \\
\hline & & & & $\begin{array}{r}16.5 \\
-16.6\end{array}$ & $\begin{array}{c}90 \\
110\end{array}$ & $\begin{array}{l}20 \\
15\end{array}$ & $\begin{array}{l}39.3 \\
31.3\end{array}$ & \\
\hline & & & -22.3 & -21.6 & 110 & 11.3 & 205.2 & 150 \\
\hline $26-3,140-142$ & 604,41 & 198.20 & 25.6 & 22.2 & 90 & 13.5 & 35.0 & 100 \\
\hline
\end{tabular}

aMDF is the median destructive field (of $A F$ demagnetization) at which the remanent magnetism of a specimen decreases to $50 \%$ of its initial value: $X_{\text {in }}$ is the initial susceptibility of a specimen: $Q_{n}$ is the
Koeniesberger ratio of NRM: peak field strength listed in remarks column is that at which inclination of AFD remanent magnetization was taken; for other notations refer to Table 7.

sea floor. In contrast, shear-strength values for Hole 446 are relatively high within the upper 60 meters of the sediment column. The top 60 meters of sediment in Hole 446, therefore, behaves the same as the Shikoku Basin sediments between depths of 80 and 160 meters. 


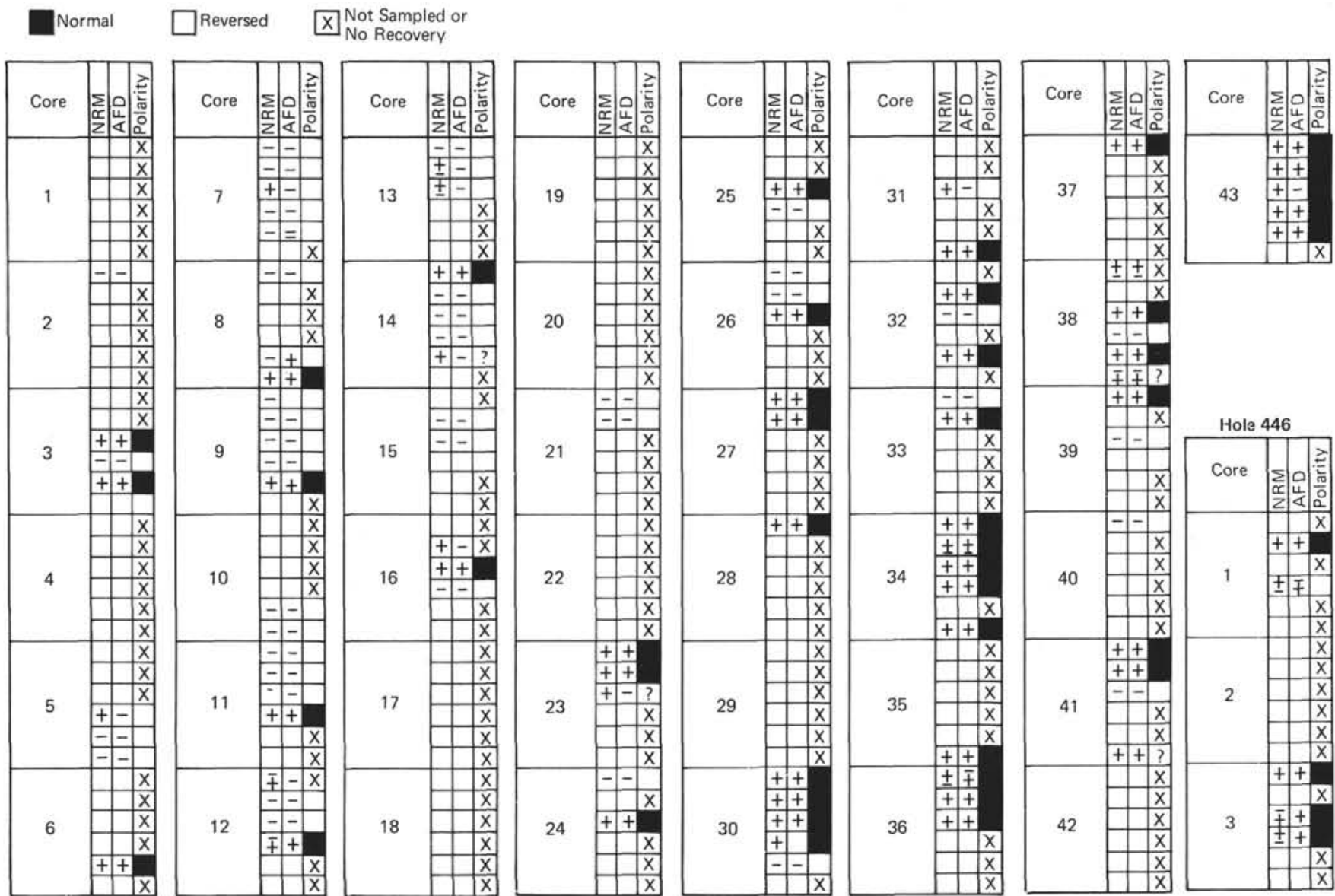

Figure 10. Results listed in Table 7 illustrated in descending order. Also shown are diagrams for some basalt cores next to the bottom layer of sediments.

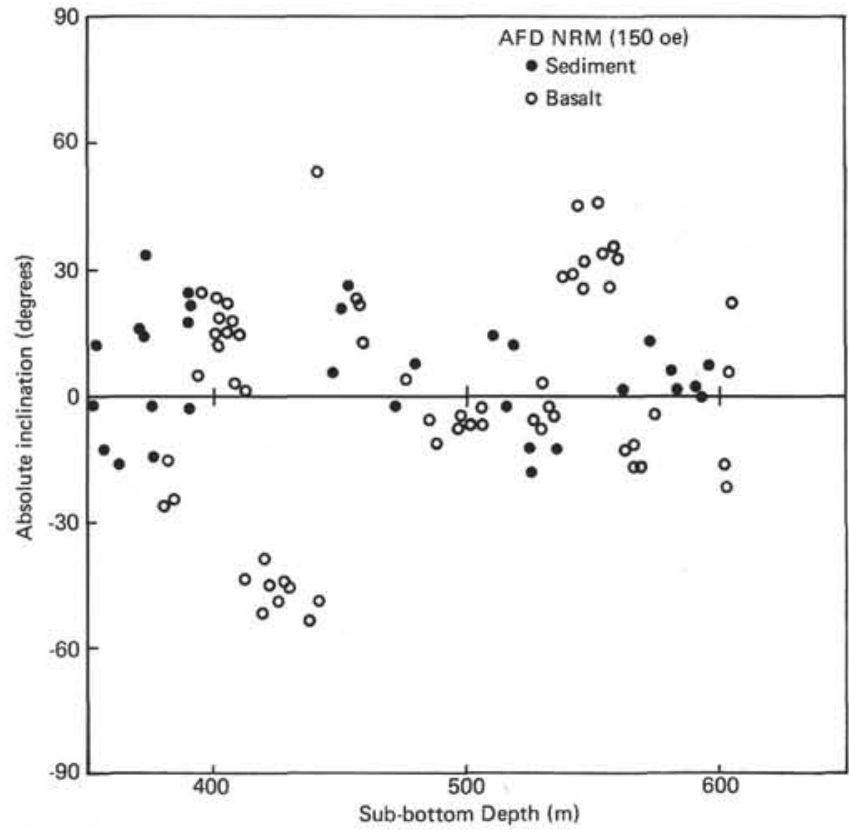

Figure 11. Stable-NRM inclination values for all samples from Hole 446A plotted against sub-bottom depth. Data for Hole 446 are also plotted between 350 and 400 meters.
Sonic velocities in Hole 446 sediments range from 1.55 to $1.60 \mathrm{~km} / \mathrm{s}$ in the upper 140 meters of the hole (Figure 15). A thin layer of chert at about 140 meters (point A in Figure 15) causes velocities to increase to $2.85 \mathrm{~km} / \mathrm{s}$. This chert layer probably corresponds to the uppermost seismic reflector observed at the site. Velocities below this layer are lower, ranging from 1.5 to 1.6 $\mathrm{km} / \mathrm{s}$. Velocities increase again at 210 meters (point B in Figure 15). The scatter in sonic velocities below this depth is caused by the wide lithologic variability of the sediments. Point B is the logical choice for the position of the second seismic reflector at Site 446, but the calculated travel time from A to B is smaller than the travel time determined from the reflection profile. It is possible that any lithologic unit below B, particularly the sandstones, may correspond to the second seismic reflector. The velocity increase at $\mathrm{C}$ in Figure 15, for example, may be significant enough to produce an acoustic reflector.

The third seismic reflection at Site 446 corresponds to the uppermost basaltic sill in the sequence of sills penetrated in Hole 446A. The interlayering of sills and sediments produced an alternating sequence of high and low sonic velocities. Sonic velocities for the basalts are generally about $4.5 \mathrm{~km} / \mathrm{s}$. Velocities in unit $2 \mathrm{~A}$, however, exceed $5.0 \mathrm{~km} / \mathrm{s}$ and reach a maximum of 5.9 $\mathrm{km} / \mathrm{s}$. Interesting variations of velocity can be observed 


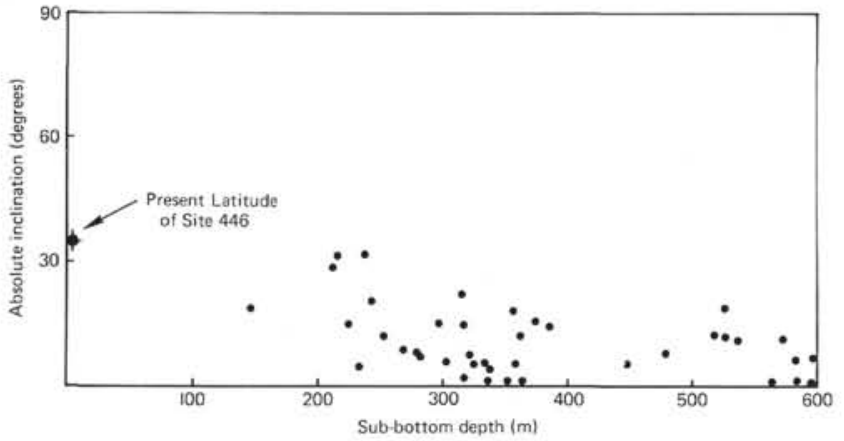

Figure 12. Absolute values of stable NRM inclinations, bottom depth. Mixed data for Holes 446 and $446 A$.

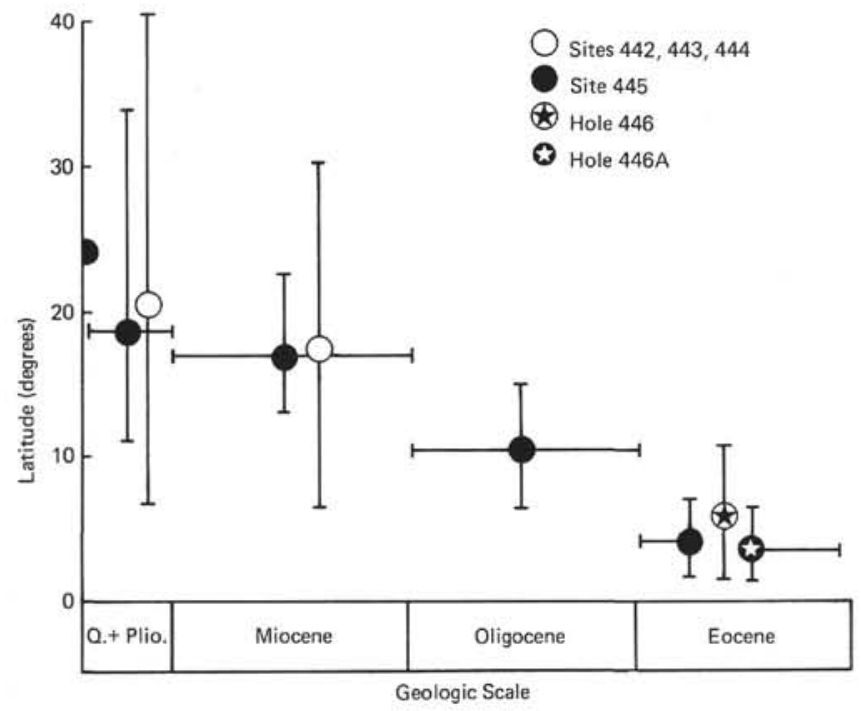

Figure 13. Latitudes of Sites 442 through 446, plotted against ages determined from the shipboard paleontological studies. Vertical bars represent probable deviations calculated from the standard deviations of NRM inclination values; horizontal bars represent time spans for the data.

within individual basalt layers. Velocities increase to a maximum within certain units, and then decrease toward the bottom of the layer (Figure 16). In sub-units 6D and 6E (Figure 16), however, velocities decrease with depth and then increase. This pattern may reflect the presence of two distinct units (see igneous petrology section). Sonic velocities for sediments between the basalt layers average about $2.0 \mathrm{~km} / \mathrm{s}$ in the upper portion of the sequence, and tend to increase toward the bottom of the hole, perhaps reflecting a greater degree of thermal metamorphism or induration.

Approximately 75 per cent of the material recovered from Hole $446 \mathrm{~A}$ is basalt, and the remainder is sediment. Assuming that these values reflect the true proportions of each rock type, and assuming average velocities of 4.5 and $2.0 \mathrm{~km} / \mathrm{s}$ for basalt and sediment, respectively, the average bulk interval sonic velocity for the entire sill-sediment sequence is about $3.9 \mathrm{~km} / \mathrm{s}$. Although very low, this is a realistic value for the sonic velocity of layer 2A (e.g. Christensen and Salisbury,
1975). This value would be higher if the effect of overburden pressure were taken into consideration. The numerous cracks and veins observed in the basalts tend to lower the average velocity.

Sonic-velocity variations observed in Site 446 basalts are primarily related to variations in porosity and, therefore, vesicularity. The inverse relationship between sonic velocity and porosity is shown in Figure 17. The correlation coefficient is -0.83 , and the least-squares parameters (slope -8.008 , intercept 5.7125 ) are similar to those reported for Site 443 (see physical-properties section, Site 443 report). The high grain densities for Site 446 (Table 10) indicate that mineral alteration does not significantly influence sonic velocity. Most wetbulk-density values plot along density-porosity theoretical curves for non-altered basalts (Figure 18). Wetbulk-density variations, therefore, are also related to changes in porosity, suggesting that the empirical relationship between sonic velocity and wet-bulk density presented in Figure 19 is expected. The correlation coefficient for this relationship is 0.83 . Thermal conductivity is also inversely related to porosity (Figure 20), although the correlation coefficient, 0.65 , is low and the scatter is considerable. The linear fit, however, is very similar to that derived for Site $\mathbf{4 4 3}$ thermal conductivity data (see physical-properties section, Site 443 report).

\section{CORRELATION OF GEOPHYSICAL DATA WITH DRILLING RESULTS}

\section{Seismic Profile and Lithology of Recovered Samples}

Site 446 is located on a shot point 6000 of line 3-2 of the multichannel seismic profile of S/V Kaiyo-Maru. The upper layer, with two-way normal time of $0.4 \mathrm{sec}-$ onds, is well stratified and horizontal. At least two reflectors are recognized. The underlying layer is semistratified, but the reflectors are very rugged, and even discontinuous; its bottom is unclear, although one indistinct reflector is scarecely recognizable at $0.73 \mathrm{sec}-$ onds two-way normal time.

Lithology observed in the recovered cores can be correlated with these acoustic reflectors as follows (Figure 21):

1. The uppermost reflector, at 0.16 seconds, is the boundary between dark-brown pelagic clay and gray clay and mudstone with chert and ferromanganese nodules, recovered at a sub-bottom depth of about 145 meters.

2. The second reflector, at 0.30 seconds, appears to be in a mudstone-and-sandstone layer about 260 meters deep, at which sonic velocity and sedimentation rate sharply increase.

3 . Roughness of the underlying reflector indicates that sills revealed at this site are not regionally uniform. Overall continuation of this reflector in the seismic profile shows that the upper surface of the sills becomes deeper as it approaches the Daito Ridge.

\section{Magnetic Anomalies and Paleomagnetism Results}

Measurement of paleomagnetism of sediments and basalts shows that the average inclination of natural 
TABLE 9

Summary of Physical Properties of Sediments, Site 446

\begin{tabular}{|c|c|c|c|c|c|c|c|}
\hline $\begin{array}{c}\text { Sample } \\
\text { (interval in } \mathrm{cm} \text { ) }\end{array}$ & Lithology & $\begin{array}{l}\text { Sonic } \\
\text { Velocity } \\
(\mathrm{km} / \mathrm{s})\end{array}$ & $\begin{array}{l}\text { Thermal } \\
\text { Conductivity } \\
\text { (mcal/cm-s- }{ }^{\circ} \mathrm{C} \text { ) }\end{array}$ & $\begin{array}{c}\text { Shear } \\
\text { Strength } \\
\left(\times 10^{-5} \text { dynes } / \mathrm{cm}^{2}\right)\end{array}$ & $\begin{array}{l}\text { Wet-Bulk } \\
\text { Density } \\
\left(\mathrm{g} / \mathrm{cm}^{3}\right)\end{array}$ & $\begin{array}{l}\text { Porosity } \\
(\%)\end{array}$ & $\begin{array}{l}\text { Water } \\
\text { Content } \\
(\%)\end{array}$ \\
\hline $446-3-5,47-57$ & clay & 1.508 & 2.486 & 1.34 & 1.42 & 76.54 & 55.29 \\
\hline $3-5,140-141$ & $"$ & - & - & - & 1.46 & 76.42 & 53.48 \\
\hline $5-4,114-124$ & $"$ & 1.564 & 2.300 & 2.30 & 1.37 & 75.02 & 56.21 \\
\hline $6-3,128-131$ & $"$ & - & - & 0.19 & - & - & - \\
\hline $6-4,128-141$ & $"$ & 1.504 & 2.336 & 3.06 & 1.40 & 78.17 & 57.15 \\
\hline $7-1,60-63$ & $”$ & - & - & 1.92 & - & - & - \\
\hline $7-4,60-72$ & $"$ & 1.506 & 2.289 & 2.30 & - & - & - \\
\hline $7-6,60-63$ & $"$ & - & - & 4.40 & 1.34 & 80.85 & 61.93 \\
\hline $8-5,38-48$ & $"$ & 1.523 & 2.253 & 2.49 & 1.39 & 80.78 & 59.38 \\
\hline $9-3,33-43$ & $"$ & - & 2.278 & 1.05 & 1.39 & 81.49 & 59.96 \\
\hline $9-4,33-36$ & $"$ & - & - & 3.64 & - & - & - \\
\hline $9-4,90-91$ & $"$ & - & - & - & 1.35 & 83.73 & 63.37 \\
\hline $9-5,33-36$ & $"$ & 1.519 & - & - & - & - & - \\
\hline $10-5,85-88$ & $"$ & - & - & 1.53 & - & - & - \\
\hline $10-6,50-60$ & $"$ & 1.511 & 2.197 & 2.68 & 1.35 & 83.73 & 63.37 \\
\hline $10-7,23-26$ & $"$ & - & - & 1.92 & - & - & - \\
\hline $11-1,70-73$ & $"$ & - & - & 0.67 & - & - & - \\
\hline $11-2,70-73$ & $"$ & - & - & 1.24 & - & - & - \\
\hline $11-3,70-80$ & $"$ & 1.507 & 2.267 & 1.34 & 1.42 & 80.23 & 57.85 \\
\hline $11-4,30-33$ & $"$ & - & - & 5.46 & - & - & - \\
\hline $12-1,45-48$ & $"$ & - & - & 1.34 & - & - & - \\
\hline $12-2,45-48$ & $"$ & - & - & 0.67 & - & - & - \\
\hline $12-3,45-48$ & $"$ & - & - & 9.58 & - & - & - \\
\hline $12-4,45-55$ & $"$ & 1.520 & 2.283 & 4.50 & 1.37 & 83.56 & 62.47 \\
\hline $13-1,108-111$ & $"$ & - & - & 1.24 & - & - & - \\
\hline $13-2,108-111$ & $"$ & - & $\bar{a}$ & 5.07 & - & - & - \\
\hline $13-3,111-121$ & $"$ & 1.518 & 2.275 & 6.70 & 1.39 & 79.92 & 58.96 \\
\hline $13-4,108-111$ & $"$ & - & - & 11.30 & - & - & - \\
\hline $13-5,24-27$ & $"$ & - & - & 6.22 & - & - & - \\
\hline $14-2,56-59$ & $"$ & - & - & 1.72 & - & - & - \\
\hline $14-3,56-59$ & $"$ & - & - & 3.06 & - & - & - \\
\hline $14-4,56-59$ & $"$ & - & - & 3.64 & 1.55 & 73.24 & 48.36 \\
\hline $14-4,144-145$ & $"$ & - & - & - & 1.47 & 75.12 & 52.44 \\
\hline $14-5,56-59$ & $"$ & - & - & 11.90 & - & - & - \\
\hline $15-1,133-136$ & $"$ & - & - & 3.06 & - & - & - \\
\hline $15-2,133-136$ & $"$ & - & $\bar{a}$ & 8.62 & - & - & - \\
\hline $15-3,133-143$ & $"$ & 1.536 & 2.336 & 3.45 & 1.47 & 73.80 & 51.57 \\
\hline $16-4,19-32$ & " & 1.560 & 2.389 & 11.30 & 1.46 & 74.32 & 52.00 \\
\hline $18-1,10-13$ & $"$ & 1.734 & - & - & 1.53 & 72.20 & 48.37 \\
\hline $18-1,79-82$ & cherty clay & 2.848 & - & - & 1.79 & 44.57 & 25.45 \\
\hline $19-1,127-137$ & clay & 1.535 & 1.906 & - & 1.53 & 70.70 & 47.43 \\
\hline $20-1,65-75$ & mudstone & 1.563 & 2.469 & 6.10 & 1.57 & 66.15 & 43.05 \\
\hline $21-2,74-84$ & clay & 1.547 & 2.539 & 10.90 & 1.64 & 68.50 & 42.72 \\
\hline $21-2,144-145$ & mudstone & - & - & - & 1.49 & 72.94 & 50.18 \\
\hline $23-1,80-90$ & clayey mudstone & 1.581 & 2.736 & - & 1.58 & 72.43 & 47.08 \\
\hline $24-1,76-79$ & sandstone & 1.903 & - & - & 1.74 & 61.94 & 36.55 \\
\hline $24-2,79-82$ & clay & 1.773 & - & - & - & - & - \\
\hline $25-2,48-61$ & mudstone & 2.188 & 2.408 & - & 1.74 & 58.85 & 34.64 \\
\hline $26-1,43-53$ & $"$ & 2.063 & 3.306 & - & 1.59 & 66.46 & 42.76 \\
\hline $26-2,140-150$ & $"$ & - & - & - & 1.64 & 63.79 & 39.76 \\
\hline $27-1,142-145$ & $"$ & 2.179 & - & - & 1.81 & 55.73 & 31.54 \\
\hline $27-2,44-54$ & $"$ & - & 2.811 & - & - & - & - \\
\hline $28-1,76-79$ & $"$ & 1.658 & - & - & 1.60 & 68.05 & 43.49 \\
\hline $29-2,47-50$ & $"$ & 2.734 & - & - & 2.06 & 37.93 & 18.89 \\
\hline $30-4,74-77$ & sandstone & 2.129 & - & - & 1.79 & 53.39 & 30.50 \\
\hline $30-5,140-150$ & mudstone & - & - & - & 1.65 & 62.89 & 39.09 \\
\hline $31, \mathrm{CC}, 13-16$ & $"$ & 1.893 & - & - & 1.72 & 58.86 & 34.97 \\
\hline $32-2,88-91$ & $"$ & 2.100 & - & - & 1.70 & 61.64 & 37.07 \\
\hline $33-1,52-62$ & claystone & - & 2.447 & - & - & - & - \\
\hline $33-2,126-129$ & $"$ & 2.168 & - & - & 1.65 & 64.25 & 39.91 \\
\hline $34-2,123-126$ & mudstone & 2.226 & - & - & 1.80 & 54.13 & 30.74 \\
\hline $34-2,134-137$ & sandstone & $2.473^{*}$ & - & - & 1.97 & 44.99 & 23.42 \\
\hline $34-5,140-150$ & mudstone & - & - & - & 1.64 & 66.47 & 41.42 \\
\hline
\end{tabular}


TABLE 9 - Continued

\begin{tabular}{|c|c|c|c|c|c|c|c|}
\hline $\begin{array}{c}\text { Sample } \\
\text { (interval in } \mathrm{cm} \text { ) }\end{array}$ & Lithology & $\begin{array}{l}\text { Sonic } \\
\text { Velocity } \\
(\mathrm{km} / \mathrm{s})\end{array}$ & $\begin{array}{c}\text { Thermal } \\
\text { Conductivity } \\
\left.\text { (mcal } / \mathrm{cm}-\mathrm{s}^{\circ} \mathrm{C}\right)\end{array}$ & $\begin{array}{c}\text { Shear } \\
\text { Strength } \\
\left(\times 10^{-5} \text { dynes } / \mathrm{cm}^{2}\right)\end{array}$ & $\begin{array}{l}\text { Wet-Bulk } \\
\text { Density } \\
\left(\mathrm{g} / \mathrm{cm}^{3}\right)\end{array}$ & $\begin{array}{c}\text { Porosity } \\
(\%)\end{array}$ & $\begin{array}{c}\text { Water } \\
\text { Content } \\
(\%)\end{array}$ \\
\hline $\begin{array}{c}446-34-6,48-51 \\
35, \mathrm{CC}\end{array}$ & $\begin{array}{l}\text { siltstone } \\
\text { mudstone }\end{array}$ & $\begin{array}{l}2.144 \\
2.442\end{array}$ & $\begin{array}{l}- \\
-\end{array}$ & $\overline{-}$ & $\begin{array}{l}1.71 \\
1.89\end{array}$ & $\begin{array}{l}59.57 \\
52.55\end{array}$ & $\begin{array}{l}35.65 \\
28.51\end{array}$ \\
\hline $\begin{array}{c}446-36-1,142-145 \\
36-2,98-101 \\
36-3,107-109 \\
37-1,117-130 \\
38-3,132-142\end{array}$ & $\begin{array}{c}", \\
", \\
\text { claystone } \\
\text { mudstone }\end{array}$ & $\begin{array}{l}1.949 \\
1.897 \\
1.935 \\
1.733 \\
2.085\end{array}$ & $\begin{array}{c}- \\
- \\
- \\
2.294 \\
3.325\end{array}$ & $\begin{array}{l}- \\
- \\
- \\
-\end{array}$ & $\begin{array}{l}1.80 \\
1.80 \\
1.83 \\
1.73 \\
1.95\end{array}$ & $\begin{array}{l}56.94 \\
56.50 \\
63.41 \\
61.28 \\
48.99\end{array}$ & $\begin{array}{l}32.41 \\
32.16 \\
35.47 \\
36.29 \\
25.70\end{array}$ \\
\hline $\begin{array}{l}38-5,103-113 \\
39-1,26-36 \\
39-3,7-10 \\
40-1,59-62 \\
41-1,120-130\end{array}$ & $\begin{array}{c}\text { calcareous mudstone } \\
" \\
\text { mudstone } \\
\text { calcareous claystone }\end{array}$ & $\begin{array}{l}1.956 \\
2.236 \\
3.371 \\
2.060 \\
2.090\end{array}$ & $\begin{array}{c}3.275 \\
3.181 \\
- \\
- \\
3.042\end{array}$ & $\begin{array}{l}- \\
- \\
- \\
-\end{array}$ & $\begin{array}{l}1.89 \\
2.02 \\
2.14 \\
1.68 \\
1.91\end{array}$ & $\begin{array}{l}47.91 \\
41.42 \\
31.32 \\
59.54 \\
47.94\end{array}$ & $\begin{array}{l}26.04 \\
21.06 \\
14.98 \\
36.25 \\
25.71\end{array}$ \\
\hline $\begin{array}{l}41-2,140-150 \\
43-2,97-100\end{array}$ & $\begin{array}{c}" \\
\text { claystone }\end{array}$ & $1 . \overline{845}$ & $\begin{array}{l}- \\
-\end{array}$ & $\begin{array}{l}- \\
-\end{array}$ & $\begin{array}{l}1.94 \\
-\end{array}$ & $\begin{array}{c}49.07 \\
-\end{array}$ & $\begin{array}{c}25.96 \\
-\end{array}$ \\
\hline $\begin{array}{c}446 \mathrm{~A}-1-2,7-10 \\
1-3,8-18 \\
2-1,46-49 \\
10-1,42-45 \\
10-1,77-80\end{array}$ & $\begin{array}{l}\text { mudstone } \\
\text { siltstone } \\
\text { ash } \\
\text { claystone } \\
\text { ash }\end{array}$ & $\begin{array}{l}2.045 \\
1.968 \\
1.774^{*} \\
1.980 \\
1.988^{*}\end{array}$ & $\begin{array}{c}- \\
2.569 \\
- \\
- \\
-\end{array}$ & $\begin{array}{l}- \\
- \\
- \\
- \\
-\end{array}$ & $\begin{array}{l}1.73 \\
1.68 \\
- \\
- \\
-\end{array}$ & $\begin{array}{l}58.41 \\
62.31 \\
- \\
- \\
-\end{array}$ & $\begin{array}{l}34.60 \\
38.00 \\
- \\
- \\
-\end{array}$ \\
\hline $\begin{array}{l}10-2,45-48 \\
10-2,140-150 \\
10-3,20-23 \\
10-3,115-118 \\
10-5,50-53\end{array}$ & $\begin{array}{c}" \\
" \\
" \\
\text { sandstone }\end{array}$ & $\begin{array}{l}1.987 * \\
\quad- \\
1.859 * \\
2.062 \\
2.199\end{array}$ & $\begin{array}{l}- \\
- \\
- \\
-\end{array}$ & $\begin{array}{l}- \\
- \\
- \\
-\end{array}$ & $\begin{array}{l}- \\
1.69 \\
- \\
- \\
-\end{array}$ & $\begin{array}{l}- \\
58.87 \\
- \\
- \\
-\end{array}$ & $\begin{array}{l}\overline{-} \\
35.60 \\
- \\
- \\
-\end{array}$ \\
\hline $\begin{array}{l}12-3,101-111 \\
13-3,73-76 \\
13-3,73-76 \\
16-3,120-130 \\
16-4,102-105\end{array}$ & $\begin{array}{l}\text { mudstone } \\
\text { siltstone } \\
\text { volcanic ash } \\
\text { mudstone }\end{array}$ & $\begin{array}{c}1.901 \\
2.210 \\
2.245 \\
-\overline{956 *}\end{array}$ & $\begin{array}{c}2.469 \\
- \\
- \\
2.769 \\
-\end{array}$ & $\begin{array}{l}- \\
- \\
- \\
-\end{array}$ & $\begin{array}{l}1.62 \\
1.90 \\
- \\
- \\
1.74\end{array}$ & $\begin{array}{c}66.50 \\
52.30 \\
- \\
- \\
60.27\end{array}$ & $\begin{array}{l}42.12 \\
28.24 \\
- \\
- \\
35.49\end{array}$ \\
\hline $\begin{array}{l}16-4,128-131 \\
17-1,77-80 \\
17-3,50-55 \\
18-1,107-110 \\
18-2,23-30\end{array}$ & $\begin{array}{l}" \\
", \\
"\end{array}$ & $\begin{array}{l}2.149 \\
2.101 \\
2.263 \\
1.757 \\
2.057\end{array}$ & $\begin{array}{l}- \\
- \\
- \\
-\end{array}$ & $\begin{array}{l}- \\
- \\
- \\
-\end{array}$ & $\begin{array}{l}- \\
1.74 \\
1.80 \\
1.73 \\
1.90\end{array}$ & $\begin{array}{l}- \\
58.86 \\
48.33 \\
60.43 \\
21.93\end{array}$ & $\begin{array}{l}- \\
34.74 \\
27.49 \\
35.71 \\
11.84\end{array}$ \\
\hline $\begin{array}{l}19-3,22-25 \\
22-1,104-115 \\
23-1,64-67 \\
24-1,117-120 \\
24-2,28-31\end{array}$ & $\begin{array}{c}" \\
\text { claystone } \\
\text { mudstone } \\
" \\
"\end{array}$ & $\begin{array}{l}2.537 \\
3.797 \\
2.425 \\
2.304 \\
2.569\end{array}$ & $\begin{array}{l}- \\
- \\
- \\
-\end{array}$ & $\begin{array}{l}- \\
- \\
- \\
-\end{array}$ & $\begin{array}{l}- \\
2.29 \\
- \\
- \\
-\end{array}$ & $\begin{array}{l}\overline{-} \\
27.84 \\
- \\
- \\
-\end{array}$ & $\begin{array}{l}\overline{1} 2.44 \\
- \\
- \\
-\end{array}$ \\
\hline $\begin{array}{l}25-3,97-100 \\
25-3,140-150 \\
25-4,62-65 \\
26-3,59-62 \\
28-1,81-84 \\
28-1,100-103\end{array}$ & $\begin{array}{c}\text { mudstone (baked?) } \\
\text { mudstone } \\
" \\
" \\
"\end{array}$ & $\begin{array}{l}3.190 \\
- \\
2.354 \\
2.472 \\
2.145 \\
3.486\end{array}$ & $\begin{array}{c}3.525 \\
- \\
- \\
- \\
- \\
-\end{array}$ & $\begin{array}{l}- \\
- \\
- \\
- \\
-\end{array}$ & $\begin{array}{l}- \\
2.09 \\
- \\
1.99 \\
- \\
2.55\end{array}$ & $\begin{array}{c}\overline{4} .67 \\
\overline{-} \\
4 \overline{4} 48 \\
\overline{25.29}\end{array}$ & $\begin{array}{c}\overline{20.40} \\
\overline{-} \\
22.92 \\
\overline{0} \\
10.15\end{array}$ \\
\hline
\end{tabular}

aPropagation direction parallel to core axis

remanent magnetization is lower than 10 degrees. Magnetic anomalies on the crest of the Daito Ridge, measured during underway geophysical survey approaching this site, appears to show the same direction of bulk magnetization of the basement body constituting the Daito Ridge. Figure 22 shows the correlation of bottom topography and magnetic total force along the ship's track approaching Site 446 . The correspondence of a magnetic trough with each topographic high is remarkable. Considering that the ship's course was roughly north-south, and that the ridge trends roughly eastwest, this correlation indicates the nearly horizontal normal magnetization of the basement. More detailed calculation of magnetization will be done later, based upon anomaly distributions measured on the site-survey cruises. A rough estimate is that the Daito Ridge was magnetized at a position farther south, near the equator.

If this is valid for the whole igneous body of the ridge, we may be able to estimate the approximate shape of the igneous (or "'magnetic') basement underlying the flat-topped crest of the main Daito Ridge, schematically shown in Figure 22. This basement seems to be overlain by weakly magnetized limestone, mudstone, or metamorphic rocks.

Another interesting finding is the smoothness of the magnetic anomaly in the basin south of the Daito Ridge, in contrast to an appreciable amplitude of anomalies 
TABLE 10

Summary of Physical Properties of Igneous Rocks, Site 446

\begin{tabular}{|c|c|c|c|c|c|c|}
\hline $\begin{array}{c}\text { Sample } \\
\text { (interval in } \mathrm{cm} \text { ) }\end{array}$ & $\begin{array}{l}\text { Piece } \\
\text { No. }\end{array}$ & $\begin{array}{l}\text { Sonic } \\
\text { Velocity } \\
(\mathrm{km} / \mathrm{s})\end{array}$ & $\begin{array}{l}\text { Thermal } \\
\text { Conduc } \\
\text { tivity } \\
\text { (mcal/ } \\
\text { cm-s. }{ }^{\circ} \mathrm{C} \text { ) }\end{array}$ & $\begin{array}{c}\text { Wet- } \\
\text { Bulk } \\
\text { Density } \\
\left(\mathrm{g} / \mathrm{cm}^{3}\right)\end{array}$ & $\begin{array}{l}\text { Grain } \\
\text { Density } \\
(\%)\end{array}$ & $\begin{array}{l}\text { Poros- } \\
\text { ity } \\
(\%)\end{array}$ \\
\hline $446-41, C C, 22-25$ & 3 & 4.544 & - & 2.62 & 2.99 & 18.42 \\
\hline $441,6-8$ & 1 & - & - & 2.84 & 3.05 & 10.57 \\
\hline $44-2,45-55$ & $1 d$ & 5.251 & 4.469 & 2.90 & 2.99 & 4.66 \\
\hline $44-4,48-62$ & 5 & 5.381 & - & 2.96 & 3.04 & 4.17 \\
\hline $446 \mathrm{~A}-2-1,145-148$ & 8 & 4.462 & - & 2.70 & 2.96 & 13.40 \\
\hline $2-3,41-44$ & 5 & 4.444 & - & 2.70 & 3.01 & 15.76 \\
\hline $3-3,50-53$ & $3 a$ & 4.836 & - & 2.82 & 3.10 & 13.56 \\
\hline $3-4,34-37$ & 2 & 5.485 & - & 2.97 & 3.05 & 3.73 \\
\hline $4-1,32-42$ & la & 5.263 & 4.164 & 2.90 & 3.01 & 5.26 \\
\hline $4-2,44-47$ & 4 & 5.894 & - & 2.92 & 2.98 & 2.76 \\
\hline $4-3,43-53$ & $2 \mathrm{c}$ & 5.550 & 4.206 & 3.01 & 3.05 & 2.36 \\
\hline $5-1,16-27$ & 1a & 5.739 & 4.231 & 2.99 & 3.05 & 2.73 \\
\hline $5-2,24-35$ & $3 a$ & 5.593 & 4.244 & 3.03 & 3.10 & 3.34 \\
\hline $6-1,10-23$ & la & 5.844 & 4.225 & 3.00 & 3.09 & 4.38 \\
\hline $6-2,3-13$ & la & - & 4.464 & - & - & - \\
\hline $6-2,38-41$ & $3 a$ & 5.576 & - & 3.02 & 3.08 & 3.36 \\
\hline $6-2,119-121$ & $8 \mathrm{a}$ & - & $\overline{0}$ & 2.87 & 3.15 & 13.23 \\
\hline $6-3,71-81$ & $7 e$ & - & 3.225 & - & - & - \\
\hline $6-3,109-112$ & $8 \mathrm{f}$ & 4.880 & - & 2.64 & 2.97 & 16.96 \\
\hline $6-3,115-125$ & $8 \mathrm{f}$ & - & 3.697 & - & - & - \\
\hline $7-2,23-33$ & $2 \mathrm{a}$ & 4.627 & 4.128 & 2.74 & 3.02 & 13.92 \\
\hline $7-3,38-48$ & $1 \mathrm{c}$ & 4.718 & 3.808 & 2.80 & 3.13 & 15.49 \\
\hline $7-4,75-77$ & $6 a$ & - & - & 2.83 & 3.01 & 8.77 \\
\hline $7-4,138-148$ & 10 & 4.694 & 3.953 & - & - & - \\
\hline $8-1,74-77$ & 9 & 4.419 & - & 2.74 & 3.00 & 13.02 \\
\hline $8-2,72-75$ & 6 & 4.948 & - & 2.82 & 2.99 & 8.75 \\
\hline $9-1,82-85$ & $4 a$ & 4.638 & - & - & - & - \\
\hline $9-2,54-57$ & $3 \mathrm{c}$ & 4.376 & - & - & - & - \\
\hline $9-3,51-54$ & $3 \mathrm{c}$ & 4.638 & - & - & - & - \\
\hline $10-5,110-113$ & 4 & 4.518 & - & 2.64 & 3.09 & 21.76 \\
\hline $11-1,69-72$ & $8 \mathrm{~b}$ & 4.562 & - & - & - & - \\
\hline $11-2,23-26$ & 3 & $3.945^{\circ}$ & - & - & - & - \\
\hline $11-2,28-33$ & 3 & 4.406 & - & 2.59 & 2.97 & 19.35 \\
\hline $12-1,50-60$ & 3 & 4.476 & 4.381 & 2.79 & 3.09 & 14.27 \\
\hline $12-1,132-142$ & $4 \mathrm{~b}$ & - & 3.961 & - & - & - \\
\hline $12-2,69-80$ & ic & 5.250 & 4.506 & 2.73 & 3.10 & 17.61 \\
\hline $13-1,105-116$ & $8 b$ & 4.262 & 3.775 & - & - & - \\
\hline $14-1,100-110$ & $13 \mathrm{~d}$ & 4.056 & 3.689 & 2.71 & 3.05 & 16.86 \\
\hline $14-2,44-47$ & 5 & 4.428 & - & 2.76 & 3.03 & 13.11 \\
\hline $\begin{array}{l}14-2,53-63 \\
14-366-69\end{array}$ & $6 a$ & 4.211 & - & - & - & - \\
\hline $\begin{array}{l}14-3,66-69 \\
15-2,16-26\end{array}$ & $6 \mathrm{~b}$ & 4.349 & - & 2.77 & 3.02 & 12.78 \\
\hline $\begin{array}{l}15-2,16-26 \\
15-3,58-71\end{array}$ & lb & 4.291 & 3.928 & 2.80 & 3.10 & 14.26 \\
\hline $\begin{array}{l}15-3,58-71 \\
15-4,73-84\end{array}$ & $6 b$ & 4.517 & 4.033 & 2.75 & 3.03 & 14.04 \\
\hline $15-4,73-84$ & $4 \mathrm{e}$ & 4.601 & 4.175 & 2.80 & 3.00 & 10.34 \\
\hline & $\begin{array}{l}5 \\
6 \mathrm{a}\end{array}$ & $\begin{array}{l}4.763 \\
4.247\end{array}$ & - & $\begin{array}{l}2.78 \\
2.74\end{array}$ & $\begin{array}{l}2.99 \\
3.04\end{array}$ & $\begin{array}{l}10.64 \\
14.80\end{array}$ \\
\hline $\begin{array}{l}16-2,44-47 \\
17, C C, 26-29\end{array}$ & 1 & 3.838 & - & - & - & 14.00 \\
\hline $18-3,83-86$ & $6 \mathrm{~b}$ & 4.041 & - & 2.61 & 2.98 & 19.80 \\
\hline $18-4,23-26$ & 2 & 3.802 & - & 2.57 & 3.01 & 21.92 \\
\hline $18-5,29-32$ & 3 & 3.744 & - & 2.57 & 2.97 & 20.53 \\
\hline $19-1,69-72$ & $3 a$ & 3.965 & - & 2.66 & 3.02 & 17.78 \\
\hline $19-5,18-21$ & & 5.042 & - & 2.71 & 3.03 & 16.10 \\
\hline $20-1,96-98$ & $9 \mathrm{~b}$ & - & - & 2.78 & 3.10 & 15.41 \\
\hline $20-1,105-115$ & $9 \mathrm{~b}$ & 4.751 & 3.747 & - & - & - \\
\hline $20-2,82-85$ & 9 & 4.319 & - & - & - & - \\
\hline $20-3,140-150$ & 9 & 3.713 & 3.619 & - & - & - \\
\hline $20-4,34-44$ & 3 & 4.619 & 3.033 & 2.66 & 3.09 & 20.89 \\
\hline $21-1,82-92$ & $3 \mathrm{c}$ & 4.132 & 3.508 & 2.71 & 3.06 & 17.38 \\
\hline $21-2,127-137$ & $9 \mathrm{~b}$ & 3.860 & 3.733 & - & - & - \\
\hline $21-3,79-89$ & $8 \mathrm{~b}$ & 4.052 & 3.992 & 2.63 & 2.87 & 13.00 \\
\hline $21-4,61-71$ & $3 a$ & 4.173 & 3.850 & - & - & - \\
\hline $21-5,7-17$ & $2 \mathrm{a}$ & - & 4.122 & - & $3 . \overline{04}$ & $15 \overline{87}$ \\
\hline $21-5,87-90$ & $4 \mathrm{c}$ & 4.445 & - & 2.72 & 3.04 & 15.87 \\
\hline $21-6,15-25$ & $1 \mathrm{~b}$ & 4.413 & 4.131 & - & - & - \\
\hline $22-1,135-145$ & 7 & 3.539 & 3.397 & - & - & - \\
\hline $\begin{array}{l}22-2,73-83 \\
22-3\end{array}$ & $\begin{array}{l}7 \\
3\end{array}$ & $\begin{array}{l}3.817 \\
4.265\end{array}$ & $\begin{array}{l}3.589 \\
3.508\end{array}$ & 2.68 & 3.05 & 18.29 \\
\hline $\begin{array}{l}22-3,78-88 \\
22-4,95-105\end{array}$ & 3 & $\begin{array}{l}4.265 \\
3.903\end{array}$ & $\begin{array}{l}3.508 \\
3.678\end{array}$ & 2.83 & 3.17 & 16.06 \\
\hline $23-2,43-53$ & $\begin{array}{l}1 \mathrm{~g} \\
\mathrm{le}\end{array}$ & $\begin{array}{l}3.903 \\
4.477\end{array}$ & $\begin{array}{l}3.678 \\
4.114\end{array}$ & $\bar{z}$ & $\bar{z}$ & - \\
\hline $23-3,38-48$ & $1 \mathrm{~b}$ & & 4.117 & 2.80 & 2.99 & 9.47 \\
\hline $23-4,44-54$ & 2 & 4.915 & 4.125 & - & - & - \\
\hline $23-5,37-47$ & $2 \mathrm{a}$ & 4.643 & 3.900 & 2.89 & 3.07 & 9.20 \\
\hline $23-6,100-101$ & $7 \mathrm{c}$ & 4.388 & 3.683 & & & \\
\hline $24-1,18-21$ & $2 \mathrm{~b}$ & 4.466 & - & 2.79 & 3.13 & 16.18 \\
\hline $24-1,43-46$ & 3 & 4.408 & $\overrightarrow{353}$ & - & - & - \\
\hline $24-2,78-88$ & 1 & - & 4.353 & - & - & - \\
\hline $24-2,99-102$ & 2 & 3.961 & - & 2.60 & 2.96 & 18.50 \\
\hline
\end{tabular}

TABLE 10 - Continued

\begin{tabular}{|c|c|c|c|c|c|c|}
\hline $\begin{array}{c}\text { Sample } \\
\text { (interval in } \mathrm{cm} \text { ) }\end{array}$ & $\begin{array}{l}\text { Piece } \\
\text { No. }\end{array}$ & $\begin{array}{c}\text { Sonic } \\
\text { Velocity } \\
(\mathrm{km} / \mathrm{s})\end{array}$ & $\begin{array}{l}\text { Thermal } \\
\text { Conduc- } \\
\text { tivity } \\
\text { (meal/ } \\
\text { cm-s- }{ }^{\circ} \mathrm{C} \text { ) }\end{array}$ & $\begin{array}{c}\text { Wet- } \\
\text { Bulk } \\
\text { Density } \\
\left(\mathrm{g} / \mathrm{cm}^{3}\right)\end{array}$ & $\begin{array}{c}\text { Grain } \\
\text { Density } \\
(\%)\end{array}$ & $\begin{array}{l}\text { Poros- } \\
\text { ity } \\
\text { (\%) }\end{array}$ \\
\hline $\begin{array}{r}446 \mathrm{~A}-24-3,74-77 \\
24-4,86-89\end{array}$ & $\begin{array}{l}4 b \\
2 a\end{array}$ & $\begin{array}{l}4.551 \\
4.986\end{array}$ & - & $\begin{array}{l}2.75 \\
2.89\end{array}$ & $\begin{array}{l}3.03 \\
3.02\end{array}$ & $\begin{array}{r}13.73 \\
6.16\end{array}$ \\
\hline $\begin{array}{l}25-1,13-23 \\
25-2,69-72 \\
25-3,41-51 \\
26-1,47-57 \\
26-3,44-47\end{array}$ & $\begin{array}{l}1 \mathrm{a} \\
1 \mathrm{c} \\
1 \mathrm{~b} \\
2 \\
4 \mathrm{e}\end{array}$ & $\begin{array}{l}5.189 \\
4.745 \\
4.391 \\
4.364 \\
5.719\end{array}$ & $\begin{array}{l}4.278 \\
- \\
4.111 \\
3.892 \\
-\end{array}$ & $\begin{array}{l}2.83 \\
- \\
2.76 \\
-\end{array}$ & $\begin{array}{c}3.02 \\
- \\
3.01 \\
-\end{array}$ & $\begin{array}{c}9.70 \\
- \\
12.29 \\
-\end{array}$ \\
\hline $\begin{array}{l}26-3,140-143 \\
27-1,77-80\end{array}$ & $\begin{array}{l}7 \mathrm{~d} \\
9 \mathrm{c}\end{array}$ & $\begin{array}{l}4.884 \\
3.442\end{array}$ & - & $\begin{array}{l}2.86 \\
2.56\end{array}$ & $\begin{array}{l}3.05 \\
3.16\end{array}$ & $\begin{array}{r}9.55 \\
28.04\end{array}$ \\
\hline
\end{tabular}

${ }^{*}$ Propagation direction perpendicular to core axis.

(approximately 100 gammas) in the basin north of the Daito Ridge. Whether this is due to the thick sequence intruded by sills at Site 446, or to other modes of crustal formation, is unknown.

\section{SUMMARY AND CONCLUSIONS}

\section{Summary}

The stratigraphic succession at Site 446 consists of four lithologic units, three of which are sedimentary, and one of which consists of interlayered sedimentary rocks and 16 basalt sills.

The total penetration at Site 446 was 628.5 meters, and both a sedimentary and an igneous succession were recovered. Although we did not reach acoustic basement, drilling terminated approximately 80 meters above it.

Sedimentary unit IV is the only one with significant amounts of ash. Ash is abundant in the sediment cores from Hole 446A, both as ash beds up to 1 meter thick and as a sediment component.

The relative depth of deposition of the sedimentary units at Site 446 is shown in Figure 23. The sediment suggests that during the depositional history at Site 446 the depositional surface was at or just below the CCD. Deposition was clearly below the CCD during deposition of unit I and unit II clays. Although calcareous foraminifers and nannofossils were recovered, they are poorly preserved and appear to have been reworked. In unit III, where turbidites are common, reworked nannofossils are common, suggesting that the depositional depth of this unit was also below the CCD. Most of unit IV also was deposited below the CCD.

Sedimentation at Site 446 involves two contrasting modes of deposition. During the earlier history of the basin (mostly Eocene), the dominant deposits were turbidites and hemipelagic deposits. However, most deposits are pelagic, and pelagic deposition occurred below the CCD from the latest Eocene to the present. The rates of sediment accumulation reflect these two contrasting styles; during the last $44 \mathrm{~m}$.y., rates of sediment accumulation were very low because of the dominance of pelagic processes, whereas during the first $8 \mathrm{~m} . \mathrm{y}$. of depositional history the rates were moderate to high, because of sediment deposition by turbidity currents. 
TABLE 11

Wet-Bulk Density and Porosity from 2-Minute GRAPE Counts, Igneous Rocks, Site 446

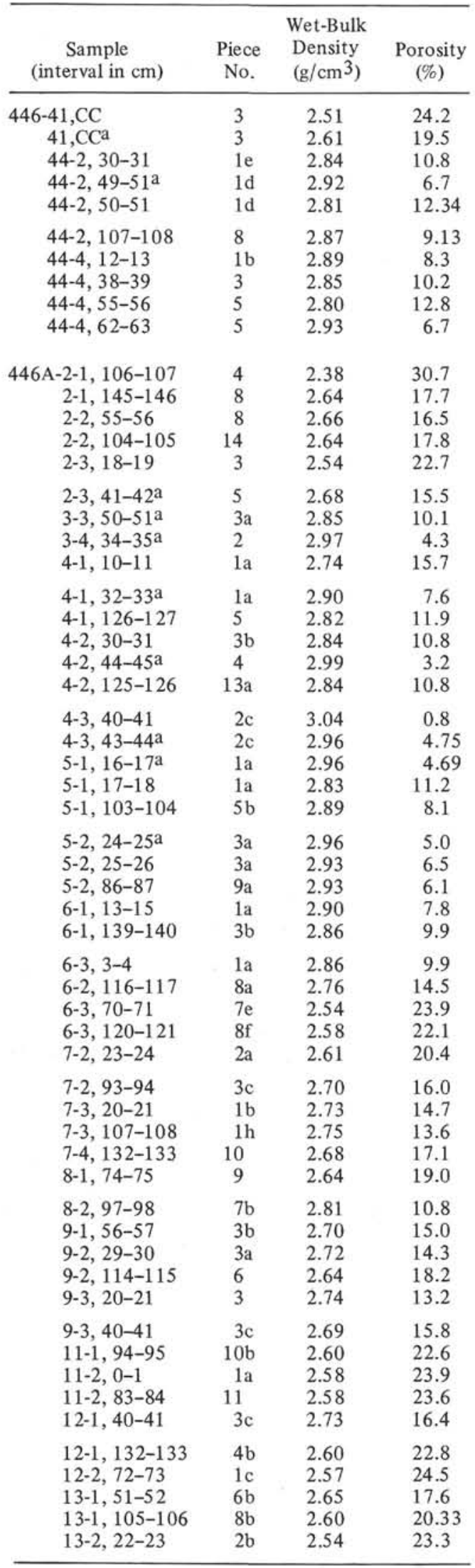

TABLE 11 - Continued

\begin{tabular}{|c|c|c|c|}
\hline $\begin{array}{c}\text { Sample } \\
\text { (interval in } \mathrm{cm} \text { ) }\end{array}$ & $\begin{array}{l}\text { Piece } \\
\text { No. }\end{array}$ & $\begin{array}{l}\text { Wet-Bulk } \\
\text { Density } \\
\left(\mathrm{g} / \mathrm{cm}^{3}\right)\end{array}$ & $\begin{array}{c}\text { Porosity } \\
(\%)\end{array}$ \\
\hline $\begin{array}{r}446 \mathrm{~A}-14-1,87-88 \\
14-2,55-56 \\
14-3,64-65 \\
15-2,18-19 \\
15-3,51-52\end{array}$ & $\begin{array}{r}13 \mathrm{~b} \\
6 \mathrm{a} \\
6 \mathrm{~b} \\
1 \mathrm{~b} \\
6 \mathrm{a}\end{array}$ & $\begin{array}{l}2.61 \\
2.71 \\
2.73 \\
2.70 \\
2.66\end{array}$ & $\begin{array}{l}21.5 \\
16.6 \\
15.5 \\
17.0 \\
19.1\end{array}$ \\
\hline $\begin{array}{l}15-3,105-106 \\
15-4,41-42 \\
15-4,86-87 \\
16-1,6-7 \\
16-1,89-90\end{array}$ & $\begin{array}{l}7 \mathrm{c} \\
4 \mathrm{a} \\
4 \mathrm{f} \\
1 \mathrm{a} \\
10\end{array}$ & $\begin{array}{l}2.71 \\
2.77 \\
2.72 \\
2.71 \\
2.70\end{array}$ & $\begin{array}{l}16.5 \\
13.8 \\
16.3 \\
16.3 \\
17.2\end{array}$ \\
\hline $\begin{array}{l}16-2,55-56 \\
18-3,91-92 \\
18-3,116-117 \\
18-4,21-22 \\
18-4,86-87\end{array}$ & $\begin{array}{l}6 \mathrm{a} \\
6 \mathrm{~b} \\
6 \mathrm{~d} \\
2 \\
10\end{array}$ & $\begin{array}{l}2.68 \\
2.58 \\
2.55 \\
2.56 \\
2.61\end{array}$ & $\begin{array}{c}18.4 \\
- \\
23.1 \\
22.1 \\
19.9\end{array}$ \\
\hline $\begin{array}{l}18-5,33-34 \\
19-1,51-52 \\
19-2,132-133 \\
19-3,0-1 \\
20-1,9-10\end{array}$ & $\begin{array}{l}3 \\
3 \mathrm{a} \\
5 \mathrm{a} \\
1 \\
2 \mathrm{a}\end{array}$ & $\begin{array}{l}2.55 \\
2.44 \\
2.57 \\
2.50 \\
2.79\end{array}$ & $\begin{array}{l}22.9 \\
28.6 \\
22.0 \\
29.1 \\
15.4\end{array}$ \\
\hline $\begin{array}{l}20-1,107-108 \\
20-3,4-5 \\
20-3,139-140 \\
20-4,35-36 \\
21-1,17-18\end{array}$ & $\begin{array}{l}9 \mathrm{~b} \\
1 \mathrm{a} \\
9 \\
3 \\
1 \mathrm{a}\end{array}$ & $\begin{array}{l}2.73 \\
2.70 \\
2.61 \\
2.62 \\
2.64\end{array}$ & $\begin{array}{l}18.1 \\
19.8 \\
24.1 \\
23.4 \\
22.6\end{array}$ \\
\hline $\begin{array}{l}21-1,108-109 \\
21-1,108-109 \\
21-2,94-95 \\
21-3,75-76 \\
21-4,10-11\end{array}$ & $\begin{array}{l}4 b \\
4 b \\
8 b \\
5 a \\
1\end{array}$ & $\begin{array}{l}2.55 \\
2.60 \\
2.60 \\
2.67 \\
2.66\end{array}$ & $\begin{array}{l}26.8 \\
24.6 \\
24.4 \\
21.0 \\
21.4\end{array}$ \\
\hline $\begin{array}{l}21-4,64-65 \\
21-5,76-77 \\
21-6,18-19 \\
22-2,73-75 \\
22-3,40-41\end{array}$ & $\begin{array}{l}3 \mathrm{a} \\
4 \mathrm{c} \\
1 \mathrm{~b} \\
7 \\
2 \mathrm{~d}\end{array}$ & $\begin{array}{l}2.63 \\
2.67 \\
2.72 \\
2.65 \\
2.75\end{array}$ & $\begin{array}{l}23.2 \\
21.3 \\
18.5 \\
19.0 \\
14.2\end{array}$ \\
\hline $\begin{array}{l}22-3,78-79 \\
22-4,13-14 \\
23-2,0-1 \\
23-3,0-1 \\
23-3,86-87\end{array}$ & $\begin{array}{l}3 \\
1 \mathrm{a} \\
1 \mathrm{a} \\
1 \mathrm{a} \\
3 \mathrm{a}\end{array}$ & $\begin{array}{l}2.73 \\
2.72 \\
2.59 \\
2.53 \\
2.66\end{array}$ & $\begin{array}{l}15.1 \\
15.7 \\
21.8 \\
24.9 \\
18.3\end{array}$ \\
\hline $\begin{array}{l}23-4,0-1 \\
23-4,120-121 \\
23-5,102-103 \\
23-6,76-77 \\
24-1,26-26\end{array}$ & $\begin{array}{l}1 \\
5 \\
6 \\
7 \mathrm{a} \\
2 \mathrm{~b}\end{array}$ & $\begin{array}{l}2.69 \\
2.52 \\
2.60 \\
2.70 \\
2.72\end{array}$ & $\begin{array}{l}17.1 \\
25.4 \\
21.5 \\
16.3 \\
15.51\end{array}$ \\
\hline $\begin{array}{l}24-2,89-90 \\
24-3,0-1 \\
24-4,100-101\end{array}$ & $\begin{array}{l}2 \\
1 \mathrm{a} \\
2 \mathrm{c}\end{array}$ & $\begin{array}{l}2.51 \\
2.47 \\
2.63\end{array}$ & $\begin{array}{l}25.7 \\
28.2 \\
19.9\end{array}$ \\
\hline
\end{tabular}

${ }^{a}$ Counts through basalt minicores.

The igneous rocks at Site 446 consist of at least 23 basalt sills which intruded sedimentary rocks of the late early Eocene, mostly mudstone. The sills consist of aphyric basalt, phyric basalt, vesicular basalt, and finegrained basalt. Chill zones were observed at both the base and the top of the sill units. The chill zones also contained isolated fragments of mudstone which were incorporated into the basalt during intrusion. Most of the interbedded sedimentary rocks showed baked contacts with the sills. These baked zones usually display a 


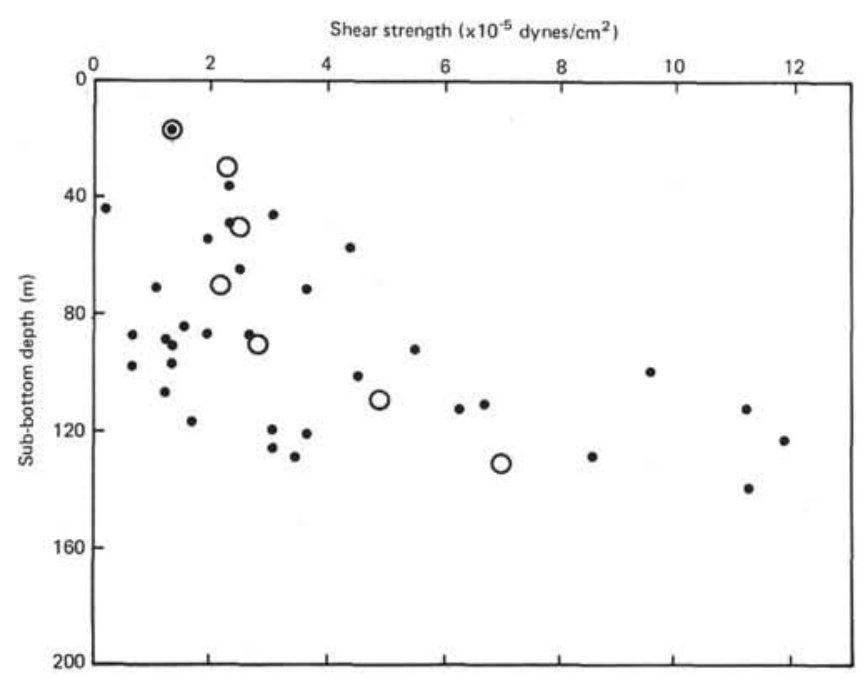

Figure 14. Shear strength versus depth for Hole 446. Large open circles are average values for each 20-meter depth increment.

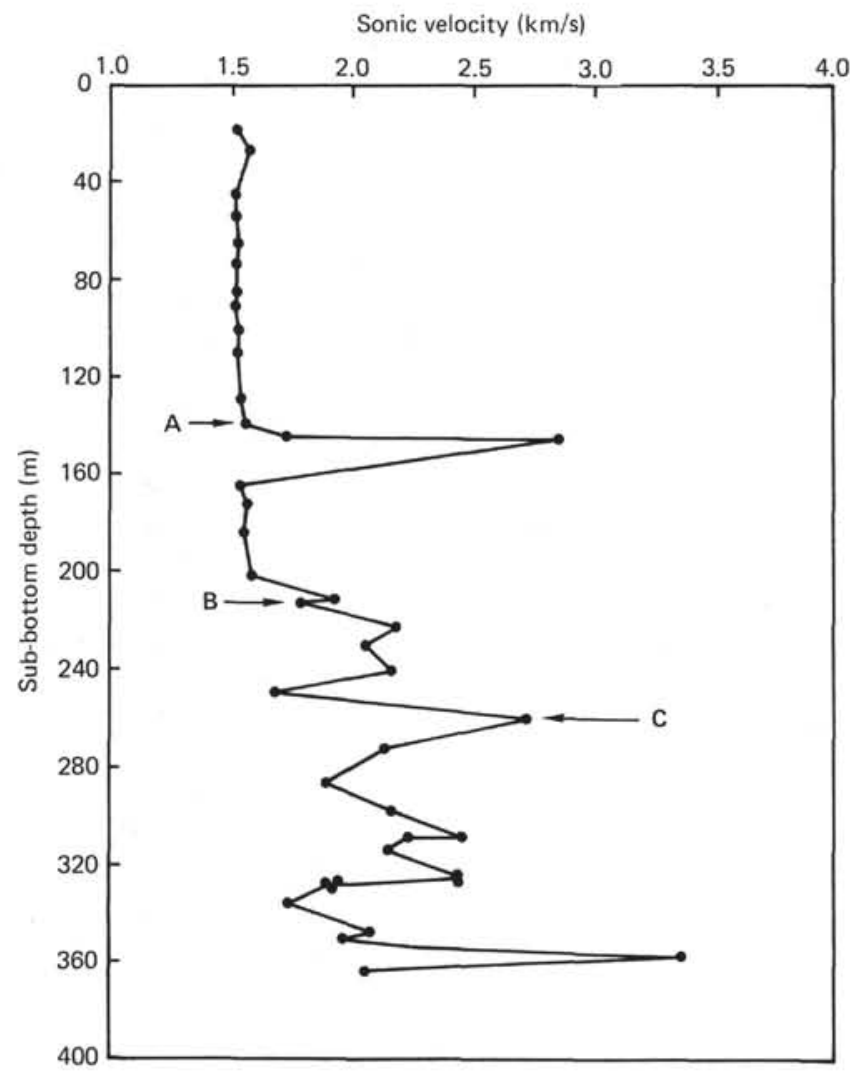

Figure 15. Sonic velocity versus depth for Site 446 sediments.

darker color. The mineralogy of the basalts is fairly complex: olivine replaced by chlorite and clay, hornblende in the upper sills, and oceanic-type plagioclase.

Paleomagnetic analysis of the sediments and sedimentary rocks indicates that Site $\mathbf{4 4 6}$ drifted in a net northerly direction over the past $52 \mathrm{~m} . \mathrm{y}$., and migrated nearly $2000 \mathrm{~km}$ to its present position. These data are in

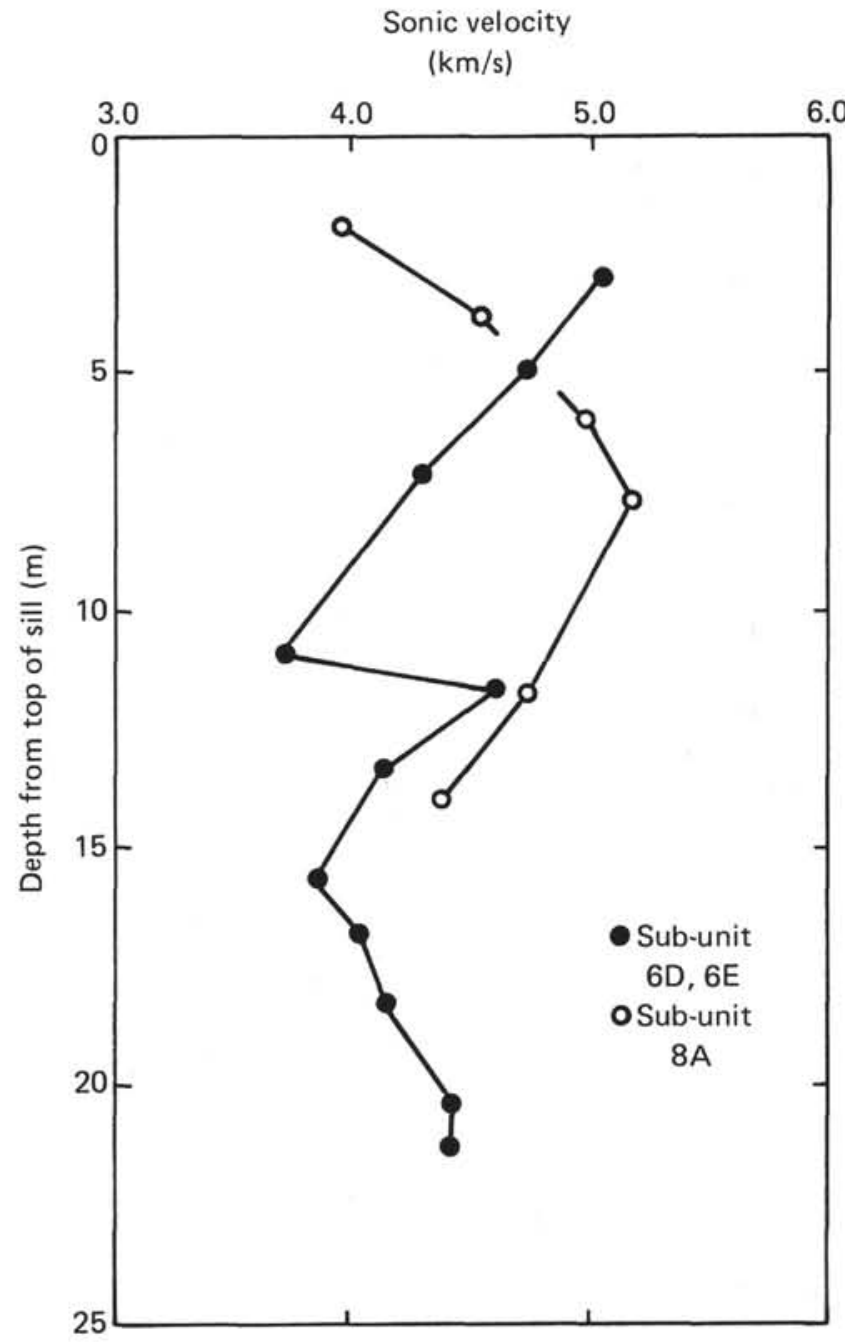

Figure 16. Sonic velocity versus depth from top of sill for igneous sub-unit $8 A$ (open circles) and sub-units $6 D$ and $6 E$ (closed circles).

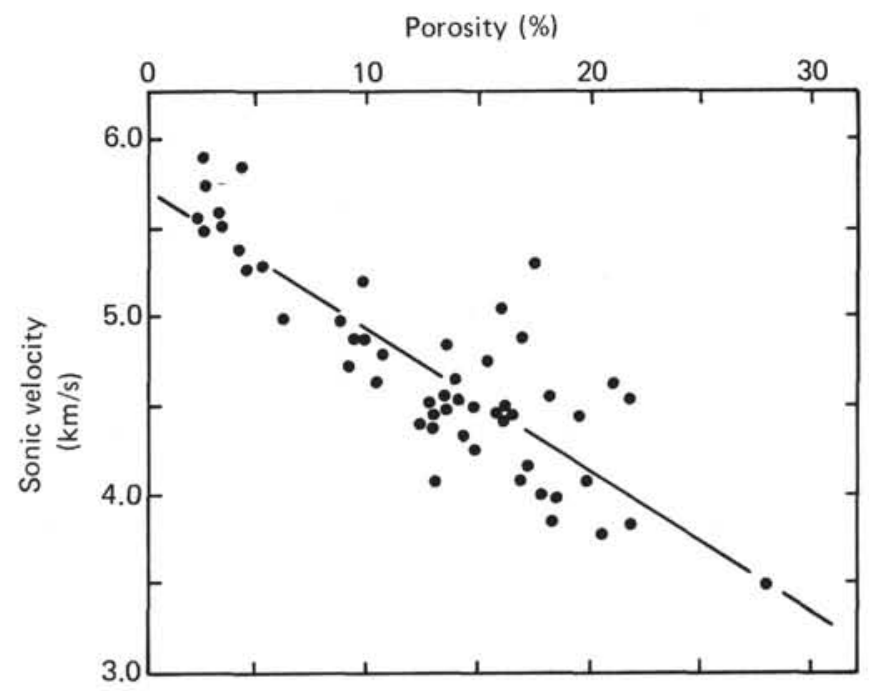

Figure 17. Relationship between sonic velocity and porosity for Site 446 igneous rocks. 


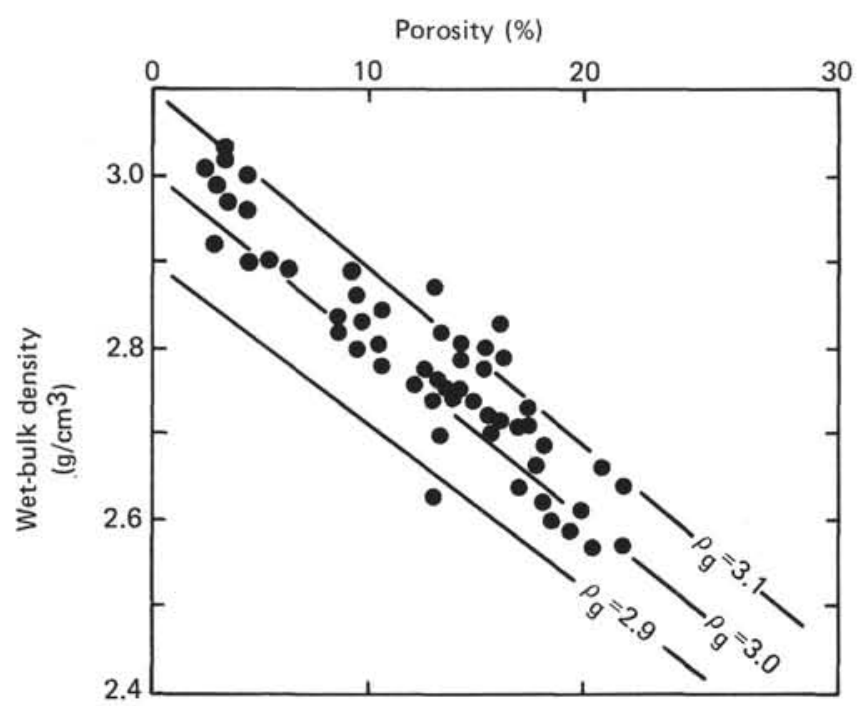

Figure 18. Wet-bulk density versus porosity for Site 446 igneous rocks. The lines predict wet-bulk density from porosity for a rock of specified grain density.

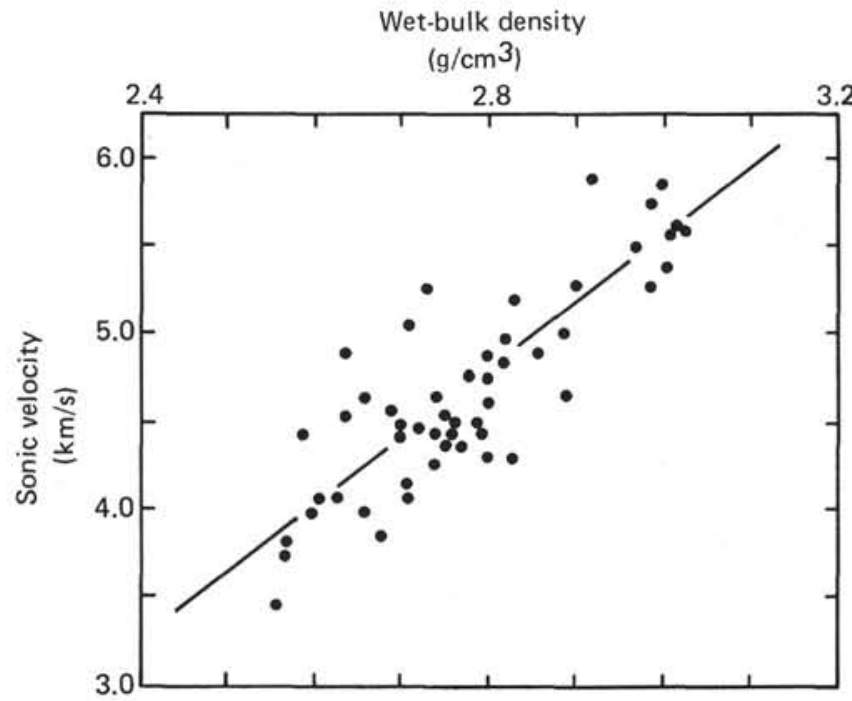

Figure 19. Sonic velocity versus wet-bulk density for Site 446 igneous rocks.

agreement with paleomagnetism measurements by Louden $(1976,1977)$ from the west Philippine Basin. The measurements show six polarity reversals preserved in the basaltic sills.

\section{Conclusions}

Our findings permit us to draw the following conclusions about the geology at Site 446:

1. The age of the oldest sediment is late early Eocene (52 m.y.). Sediment of this age is intruded by basalt sills. We interpret this age to mean that acoustic basement could be no younger than late early Eocene and is perhaps not much older. This interpretation is in agreement with the suggested age for the Daito region by Karig (1975), Watts et al. (1977), and Louden (1976, 1977); it assumes both continuity of high rates of sedi-

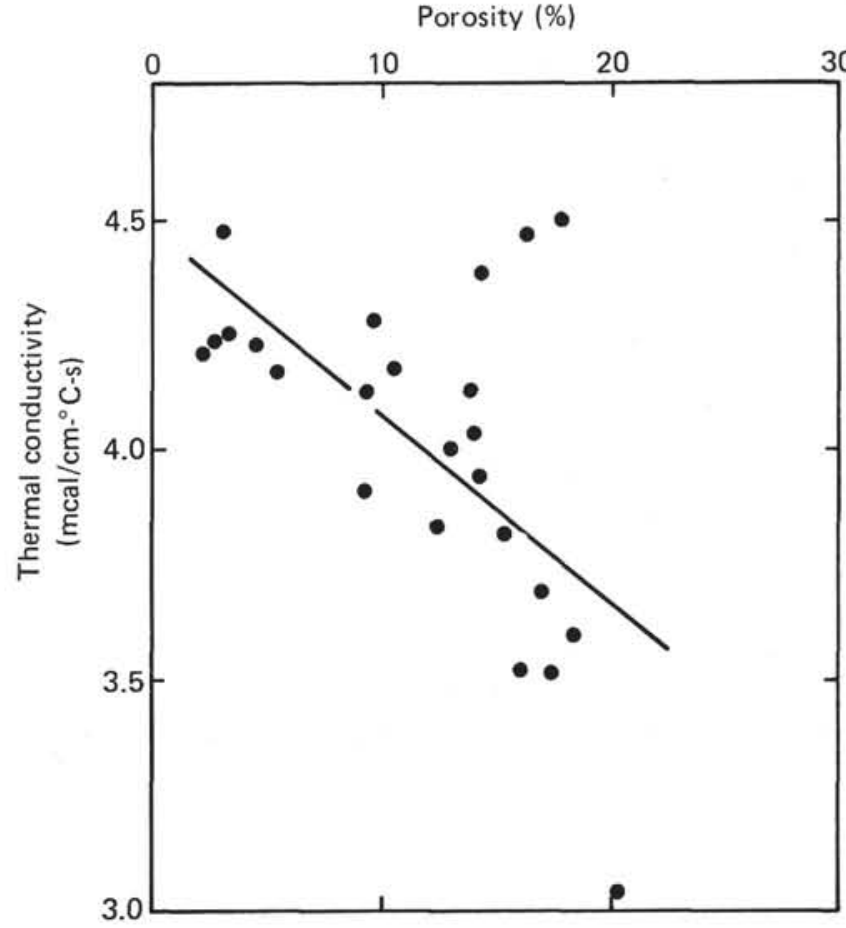

Figure 20. Thermal conductivity versus porosity for Site 446 igneous rocks.

mentation by turbidity currents below our penetration depth, and an absence of hiatuses.

2. The depositional surface at Site 446 was at or below the CCD during its depositional history.

3. The dominant sediments at Site $\mathbf{4 4 6}$ are pelagic for the last 44 m.y. of deposition, and a combination of hemipelagic deposits and turbidites for the first $8 \mathrm{~m} . \mathrm{y}$. of deposition. The sediment accumulation rates reflect these modes of sedimentation, being low for the past 44 m.y., and moderate to high during the first 8 m.y. This parallels the changes in sedimentation rates at Site 445, Site 285 in the South Fiji Basin, and Site 286 in the New Hebrides Basin (Andrews, Packham, et al., 1975; Klein, 1975).

4. A total of 23 sills of phyric, aphyric, and finegrained basalt intruded the sediments of the late early Eocene (K-Ar age 48.2 \pm 1.0 m.y.). These basalts show evidence of replacement of olivine by chlorite and clay, and they contain hornblende in the upper part. The plagioclase is petrographically similar to that of oceanic basalts. Chill zones and baked sediment confirm the intrusive origin.

5. Paleomagnetic analysis has demonstrated that Site 446 drifted in a northerly direction from the equator at least $2000 \mathrm{~km}$ over the past $52 \mathrm{~m}$.y. Six polarity reversals are recorded in the intrusive basalts.

\section{REFERENCES}

Andrews, J. E., Packham, G. H., et al., 1975. Init. Repts. DSDP, 30: Washington (U. S. Govt. Printing Office).

Berggren, W. A., 1972. A Cenozoic time-scale-some implications for regional geology and paleogeography. Lethaia, 5, $195-215$. 


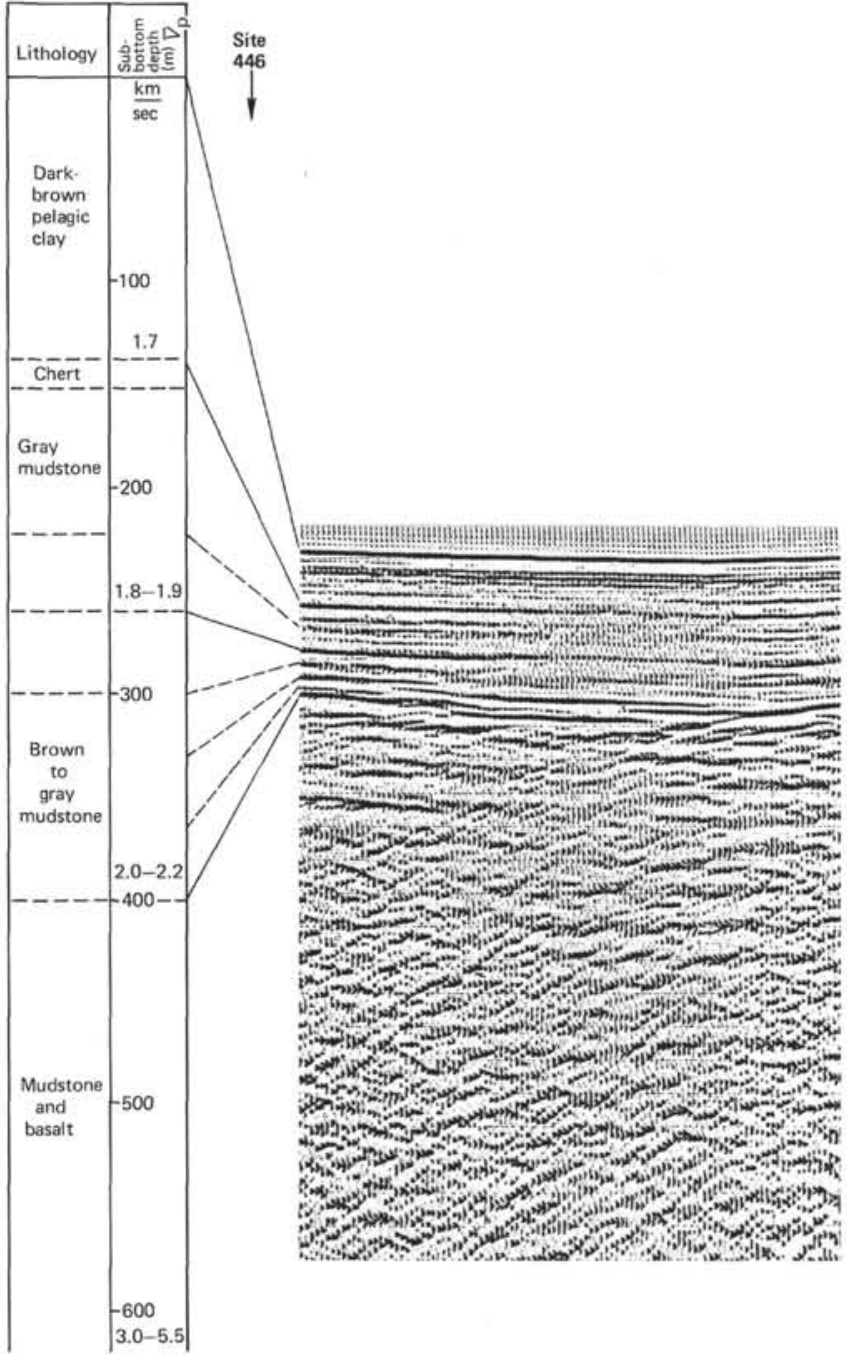

Figure 21. Correlation of lithology of Holes 446 and $446 \mathrm{~A}$ with seismic-reflection profile.

Berggren, W. A., and Van Couvering, J. A., 1974. The late Neogene biostratigraphy, geochronology and paleoclimatology of the last 15 million years in marine and continental sequences. Palaeogeography, Palaeoclimatology, Palaeoecology, 16, 1-216.

Bukry, D., 1975. Coccolith and silicoflagellate stratigraphy, northwestern Pacific Ocean, Deep Sea Drilling Project Leg 32. In Larson, R. A., Moberly, R. M., Jr., et al., Init. Repts. DSDP, 32: Washington (U. S. Govt. Printing Office), pp. 677-718.
Christensen, N. I., and Salisbury, M. H., 1975. Structure and composition of the lower oceanic crust. Rev. Geophys., 13, 57.

Cooper, A. K., Marklow, M. K., and Scholl, D. W., 1976, Mesozoic magnetic lineations in the Bering Sea marginal basin. J. Geophys. Res., 81, 1916-1934.

Hilde, T. W. C., Uyseda, S., and Kroenke, L., 1977. Evolution of the western Pacific and its margin. Tectonophysics, $38,145-165$.

IPOD-Japan, 1977. Multi-channel seismic reflection data across the Shikoku Basin and the Daito Ridges, 1976. IPOD-Japan Basic Data Series, No. 1.

Karig, D. E., 1975. Basin genesis in the Philippine Sea. In Karig, D. E., Ingle, J. C., et al., Init. Repts. DSDP, 31: Washington (U. S. Govt. Printing Office), pp. 857-879.

Karig, D. E., Ingle, J. C., et al., 1975. Init. Repts. DSDP, 31: Washington (U. S. Govt. Printing Office).

Klein, G. deV., 1975. Sedimentary tectonics in southwest Pacific marginal basins based on Leg 30 Deep Sea Drilling Project cores from the South Fiji, Hebrides and Coral Sea Basins. Geol. Soc. Am. Bull., 86, 1012-1018.

Konda, I., Harada, K., Kitazato, H., Matsuoka, K., Nishida, S., Nichimura, A., Ohno, T., and Taka-ama, T., 1975. Some paleontological results of the GDP-1, $-8,-11$ cruises. In Geological Processes of the Philippine Sea: Tokyo (Geol. Soc. Japan).

Louden, K. E., 1976. Magnetic anomalies in the West Philippine Basin. In Sutton, G. H., Manghnani, M. H., and Moberly R. M. (Eds.), The Geophysics of the Pacific Ocean Basin and Its Margins: Am. Geophys. Union Mon. 19, pp. 253-267.

, 1977. Paleomagnetism of DSDP sediments, phase shifting of magnetic anomalies, and rotation of the West Philippine Basin. J. Geophys. Res., 82, 2989-3002.

Mizuno, A., Okuda, Y., Tamaki, K., Konoshita, Y., Nohara, M., Yuasa, M., Nakajima, M., Murakami, R., Terashima, S., and Ishibashi, K., 1975. Marine geology and geological history of the Daito Ridge area, north-western Philippine Sea. Mar. Sci., 7, 484-491, 543-548.

Saito, T. 1977. Late Cenozoic planktonic foraminifera datum levels: the present state of knowledge towards accomplishing Pan-Pacific stratigraphic correlation. Proc. First. Internat. Cong. Pacific Neogene Stratigraphy., pp. 61-80.

Shiki, T., Aoki, H., Suzuki, H., Masashino, M., and Okuda, Y., 1974. Geological and petrographical results of the GDP-8 cruise in the Philippine Sea. Mar. Sci., 6, 51-55.

van Andel, Tj. H., Heath, G. R., and Moore, T. C., Jr., 1975. Cenozoic history and paleoceanography of the central equatorial Pacific Ocean. Geol. Soc. Am. Mem., 143.

Watts, A. B., Weissel, J. K., and Larson, R. L., 1977. Seafloor spreading in marginal basins of the western Pacific. Tectonophysics, 37, 167-181. 


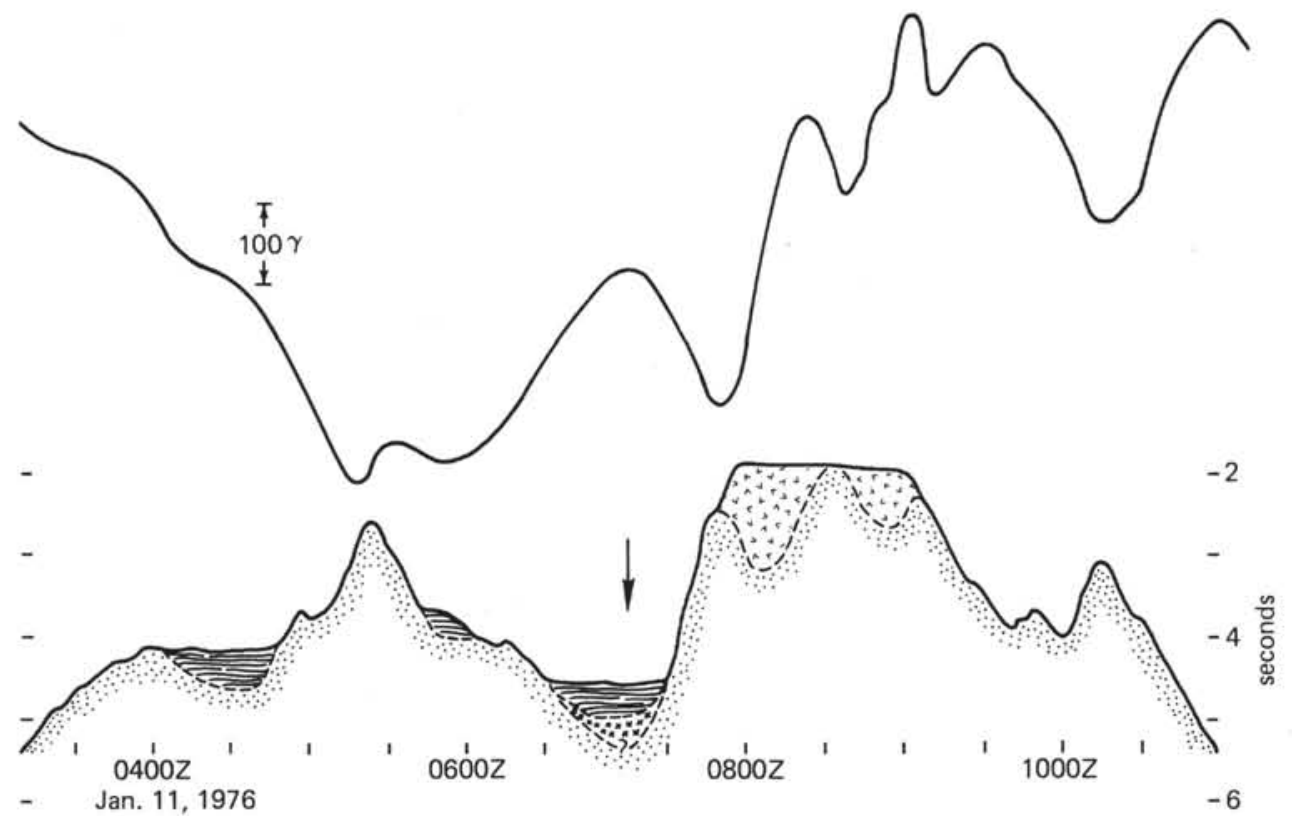

Figure 22A. Correlation of magnetic total-force anomalies with bottom topography. Sub-bottom structure beneath the flat-topped crest of the Daito Ridge is assumed to fit the observed anomalies assuming horizontal magnetization with normal polarity.

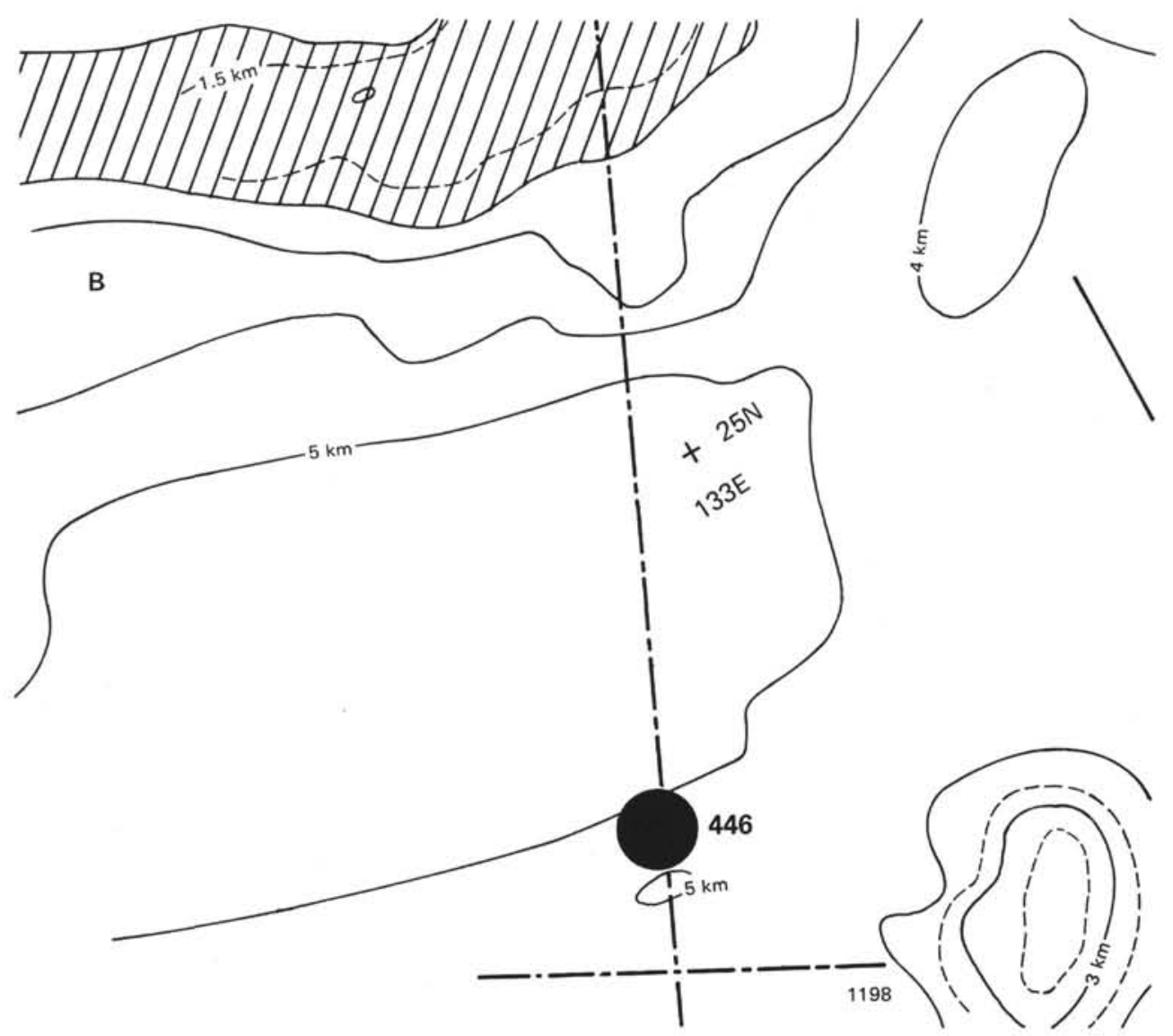

Figure 22B. Topographic map compiled with site-survey data. 


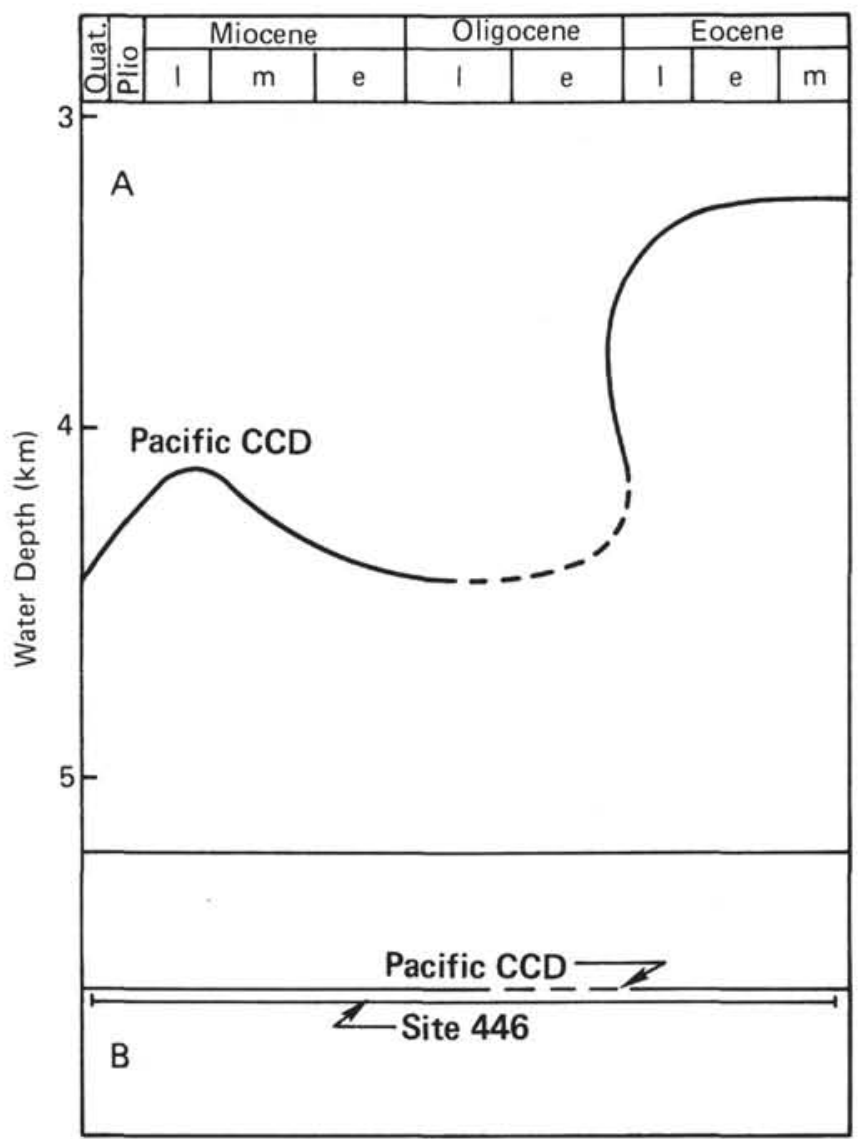

Figure 23. A. General curve showing estimated water depth of CCD in Pacific Ocean (after van Andel et al., 1975, p. 47, fig. 29). B. Relative depth of deposition at Site 446 compared to CCD curve for Pacific Ocean. 


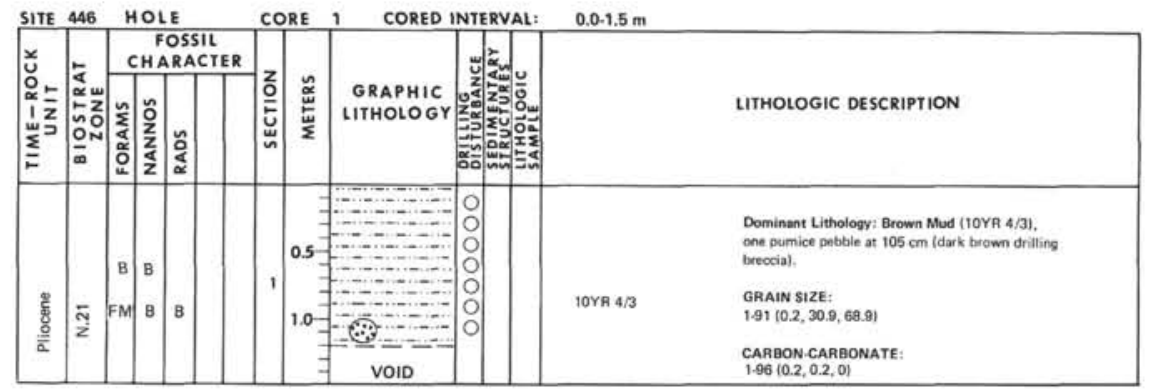

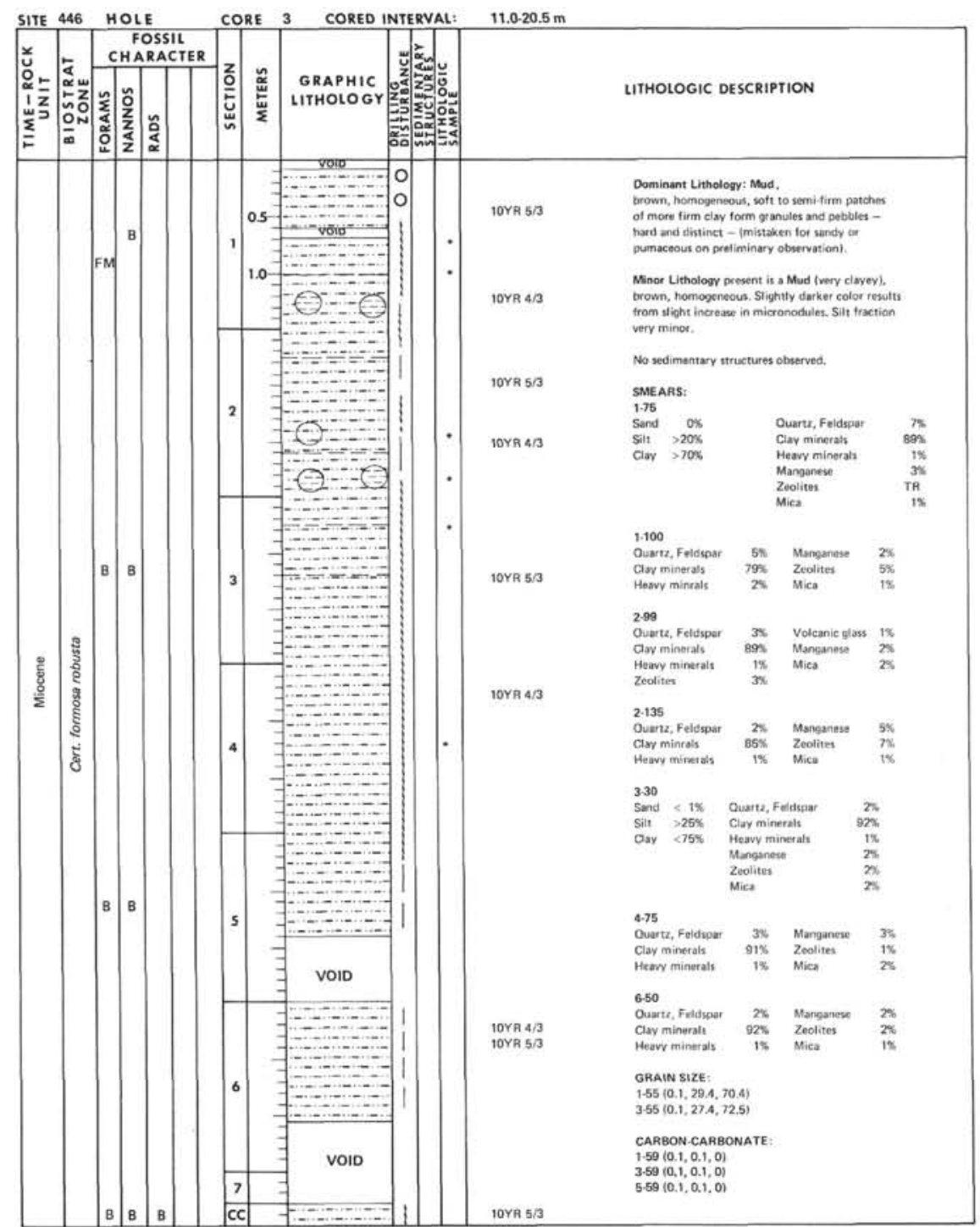

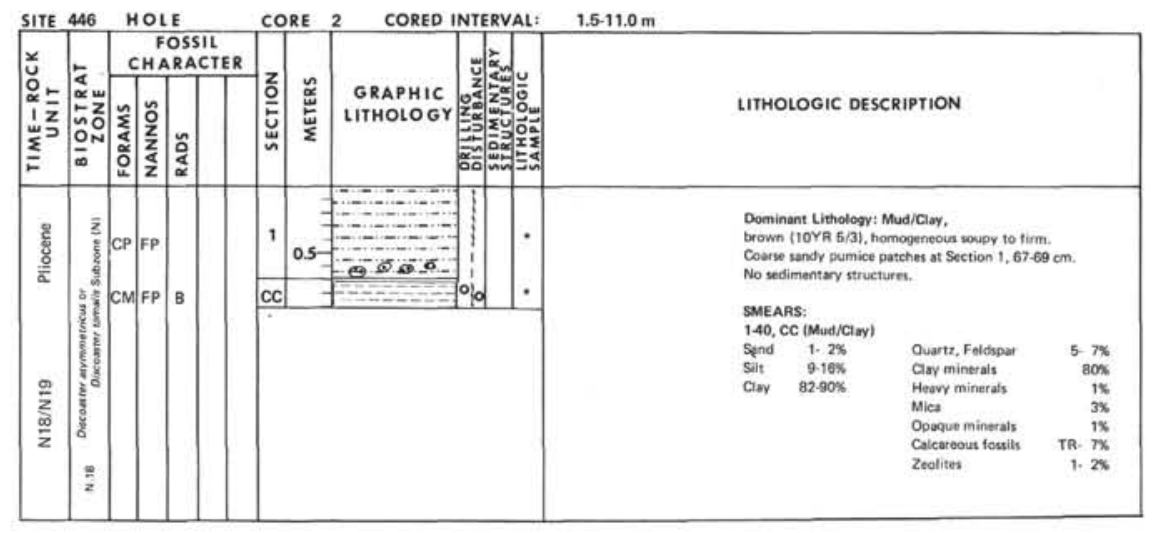




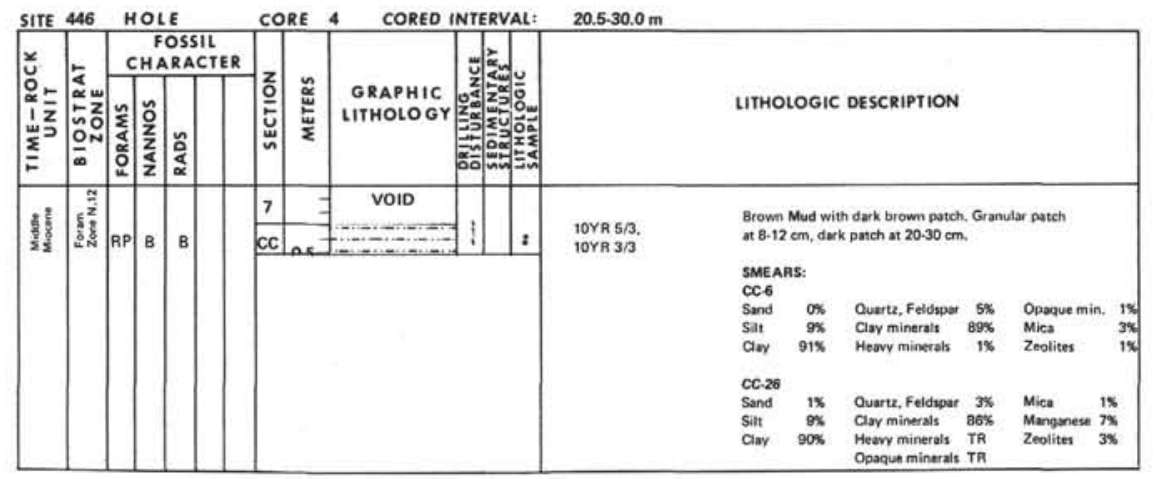

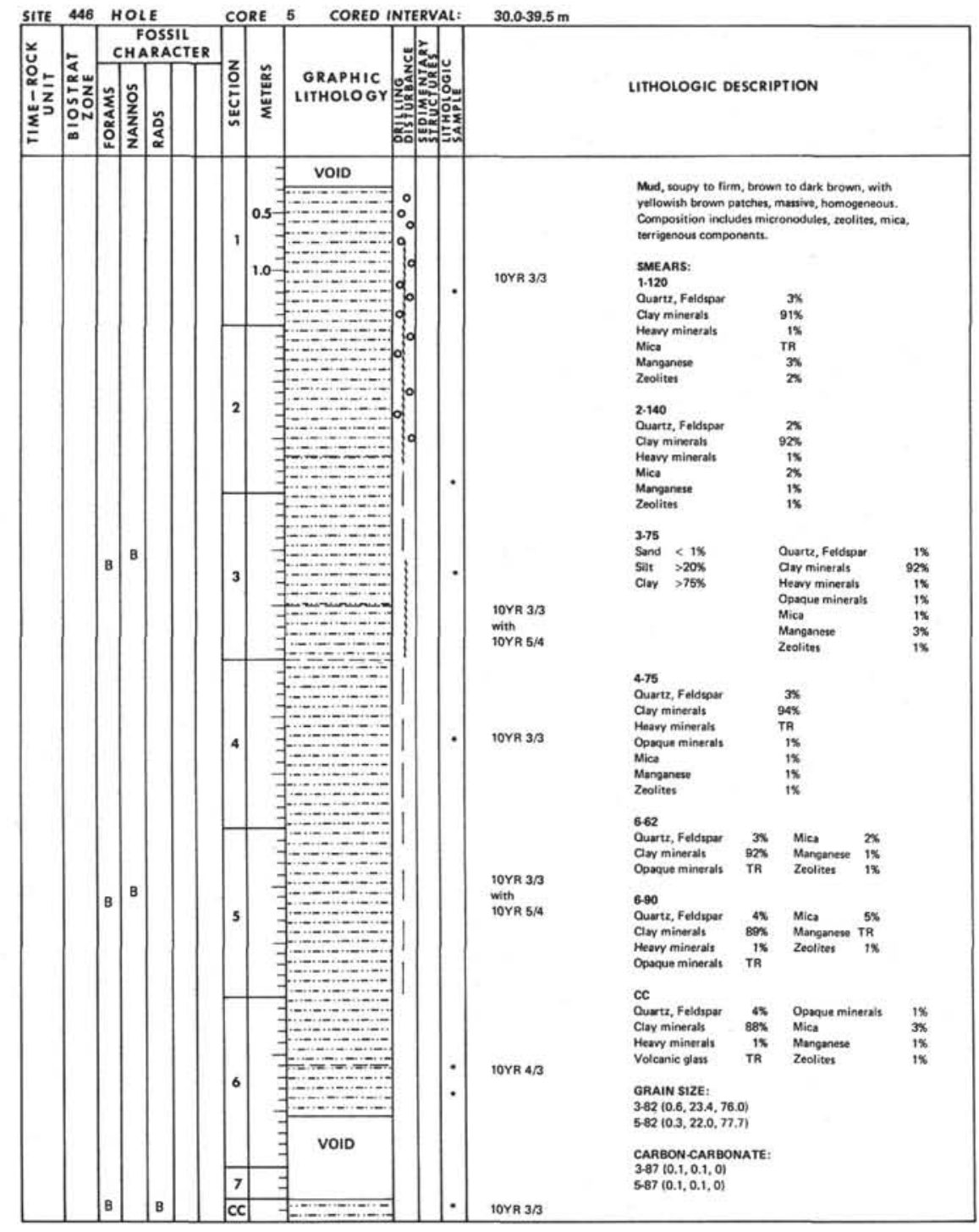



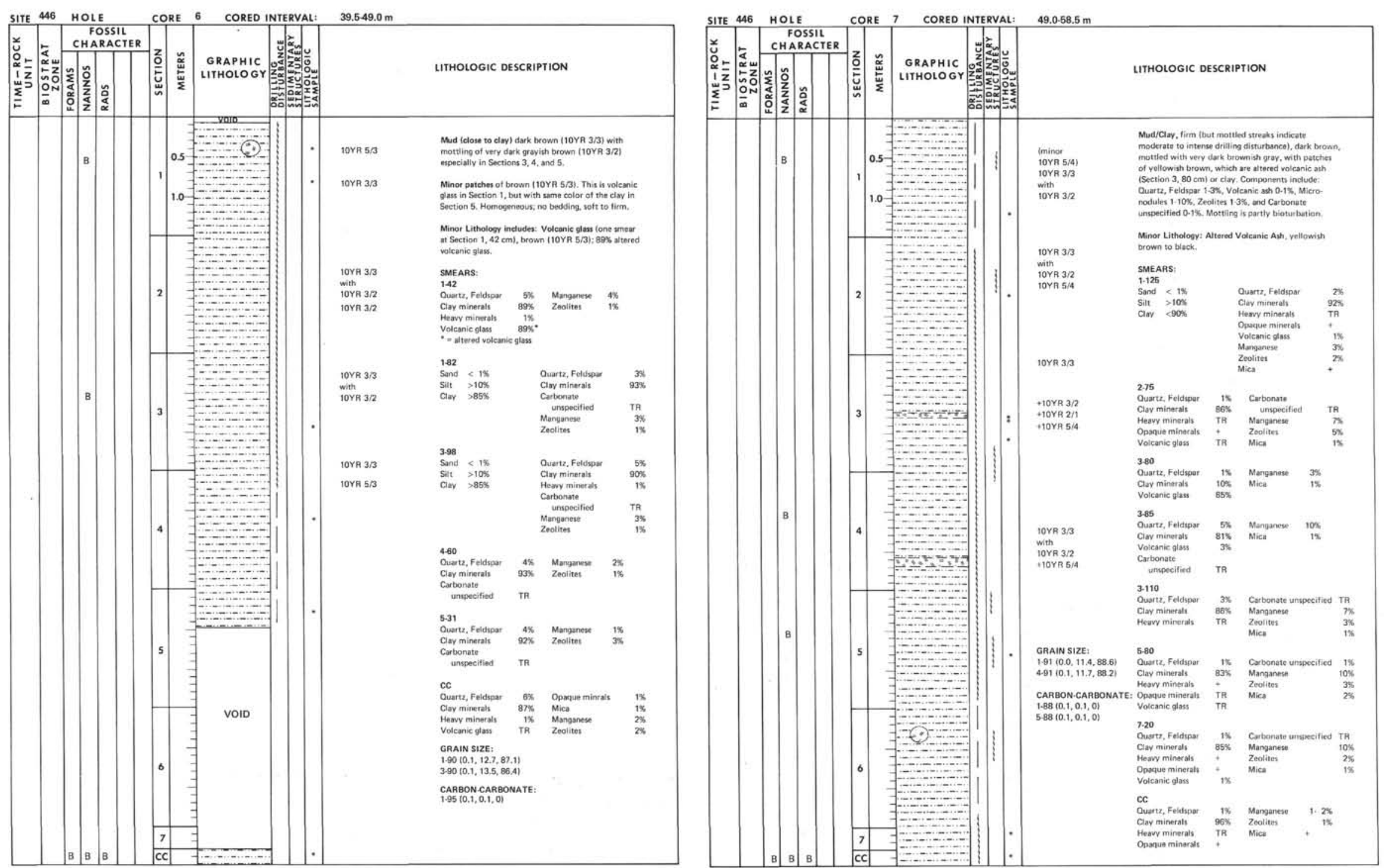


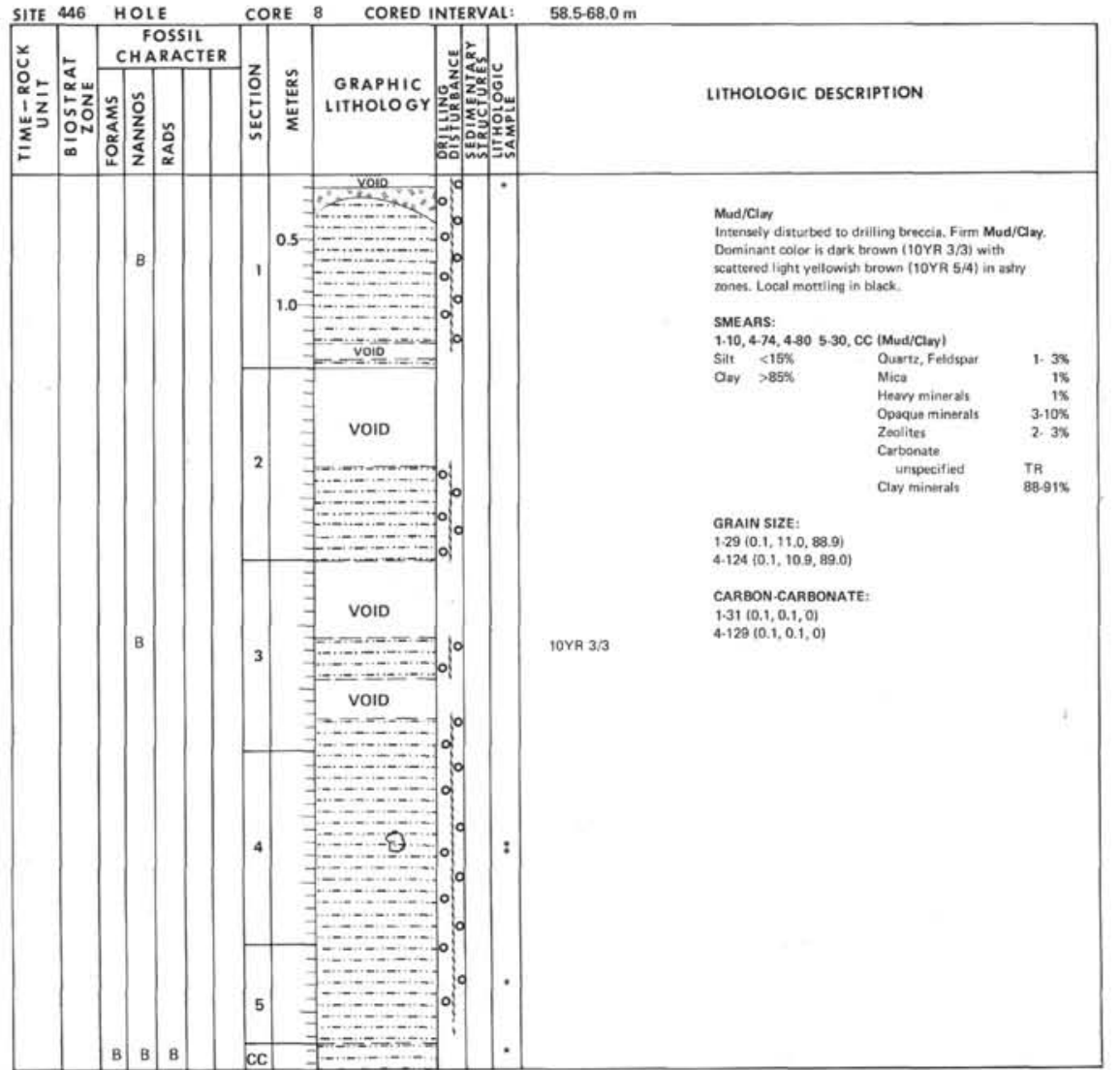

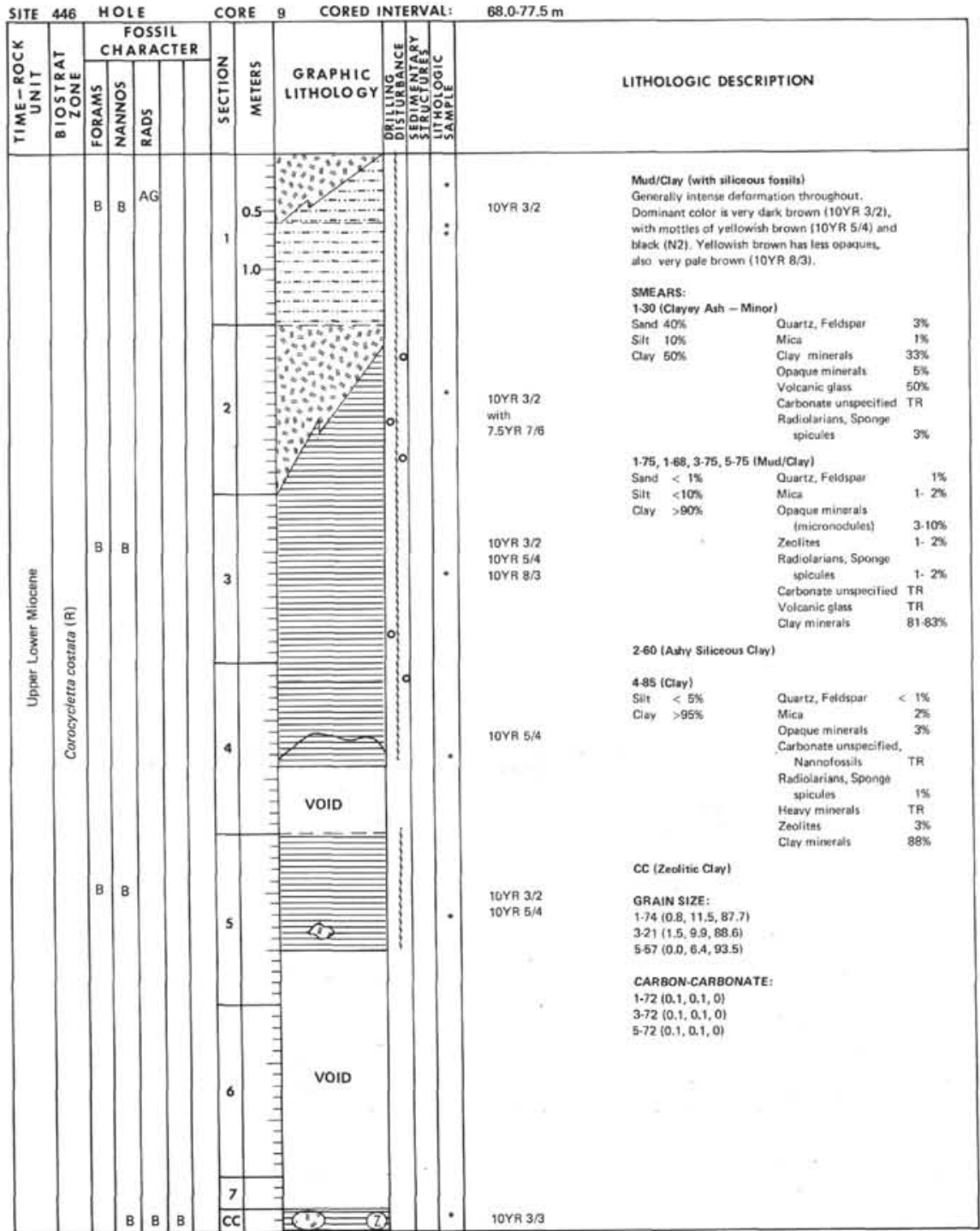



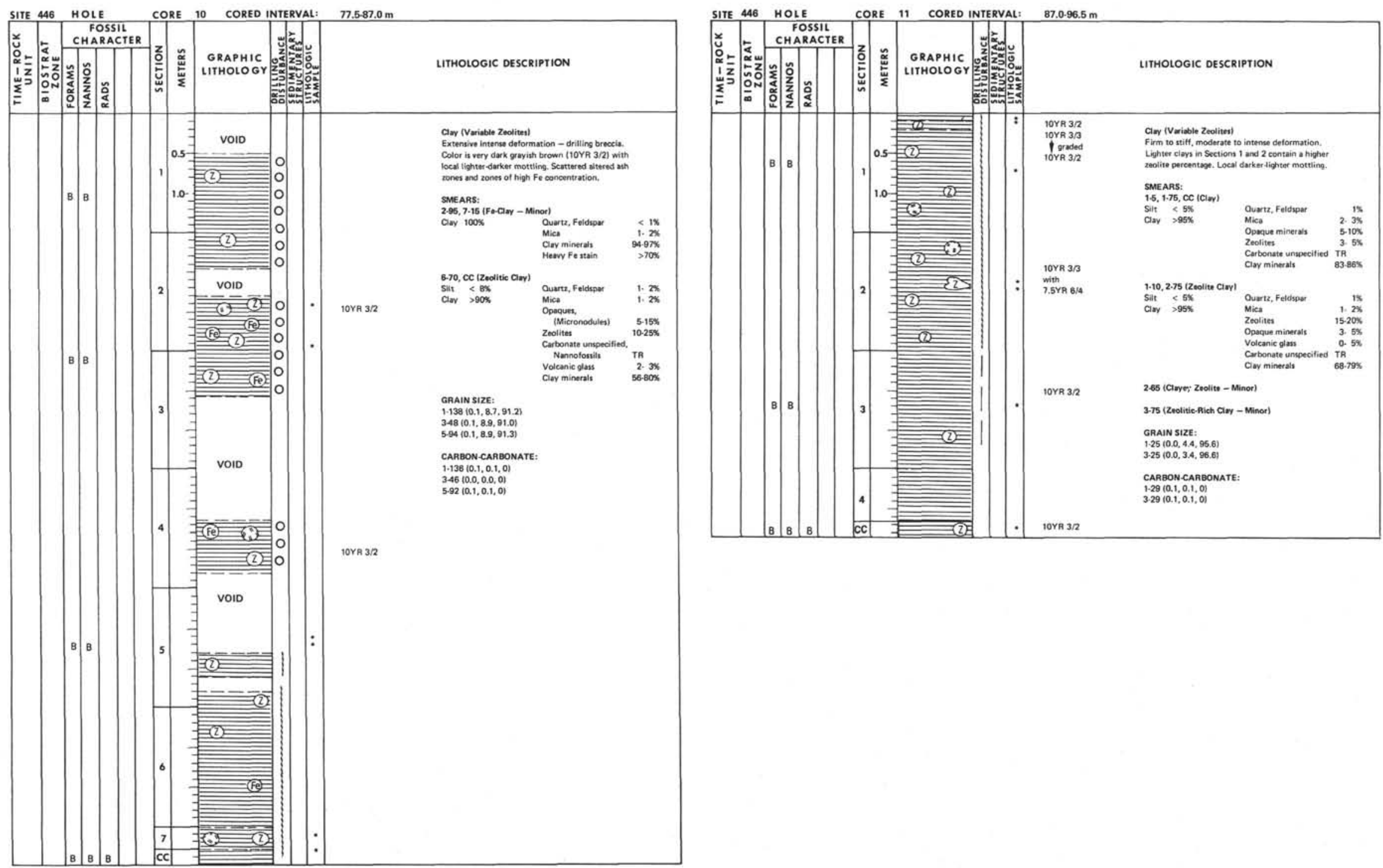


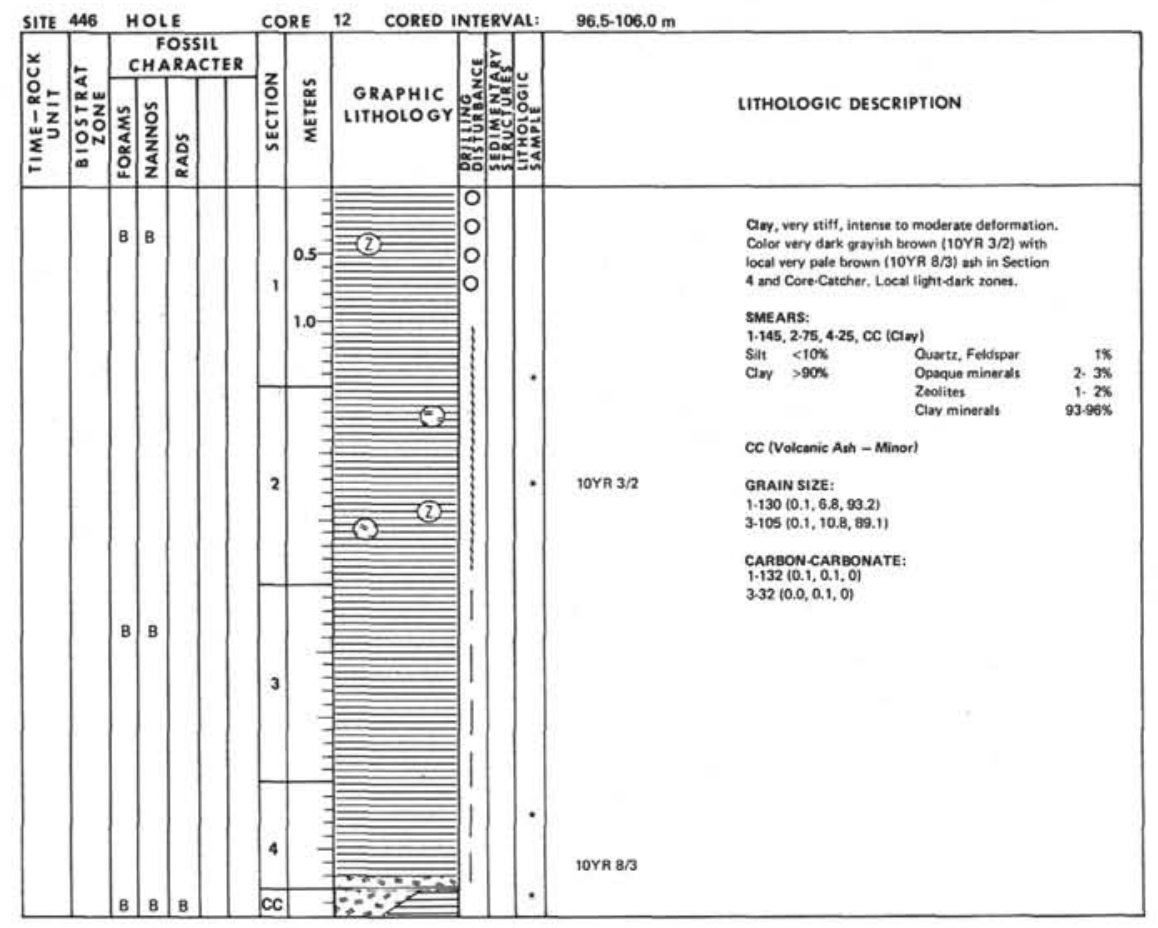

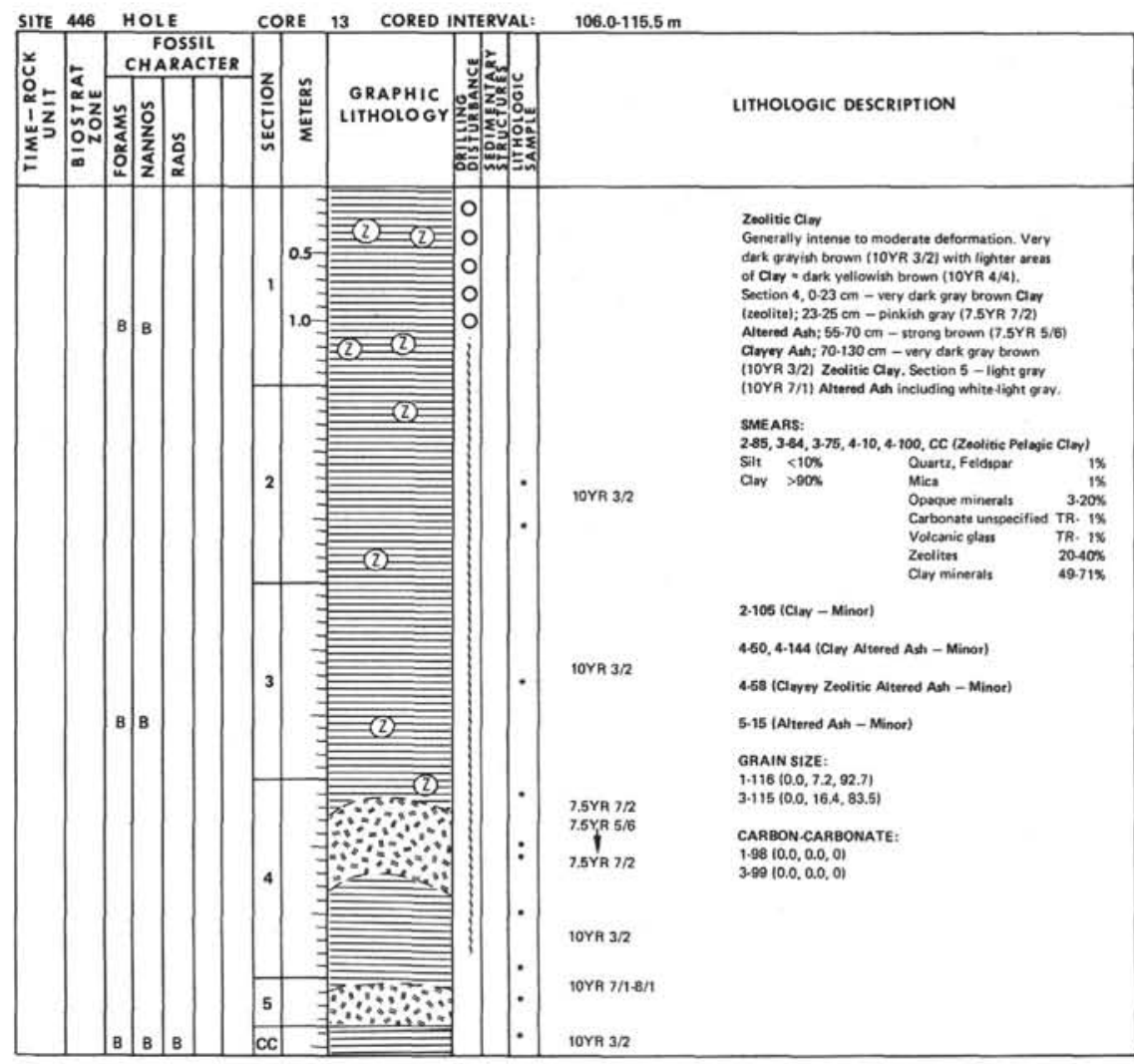




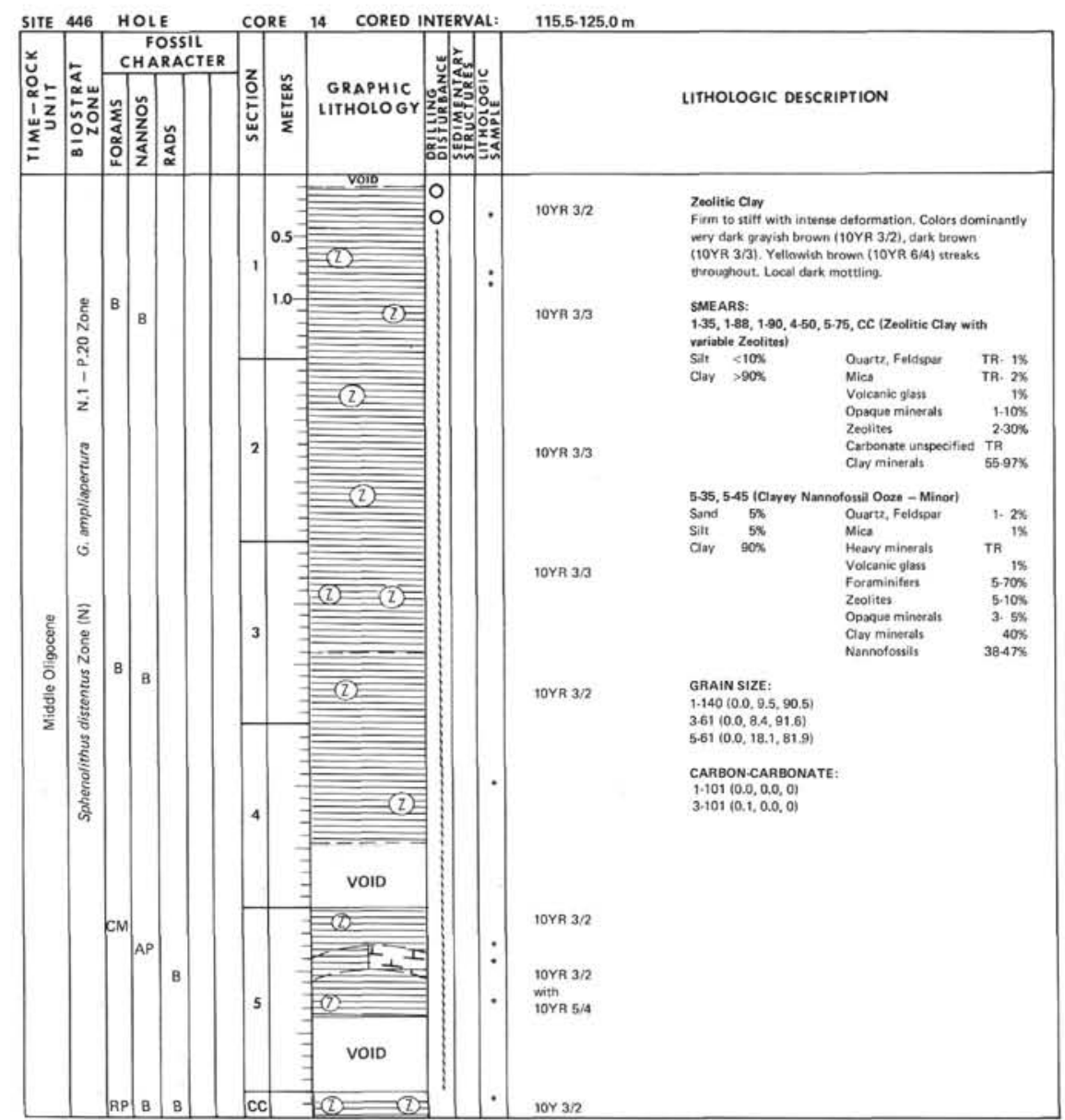

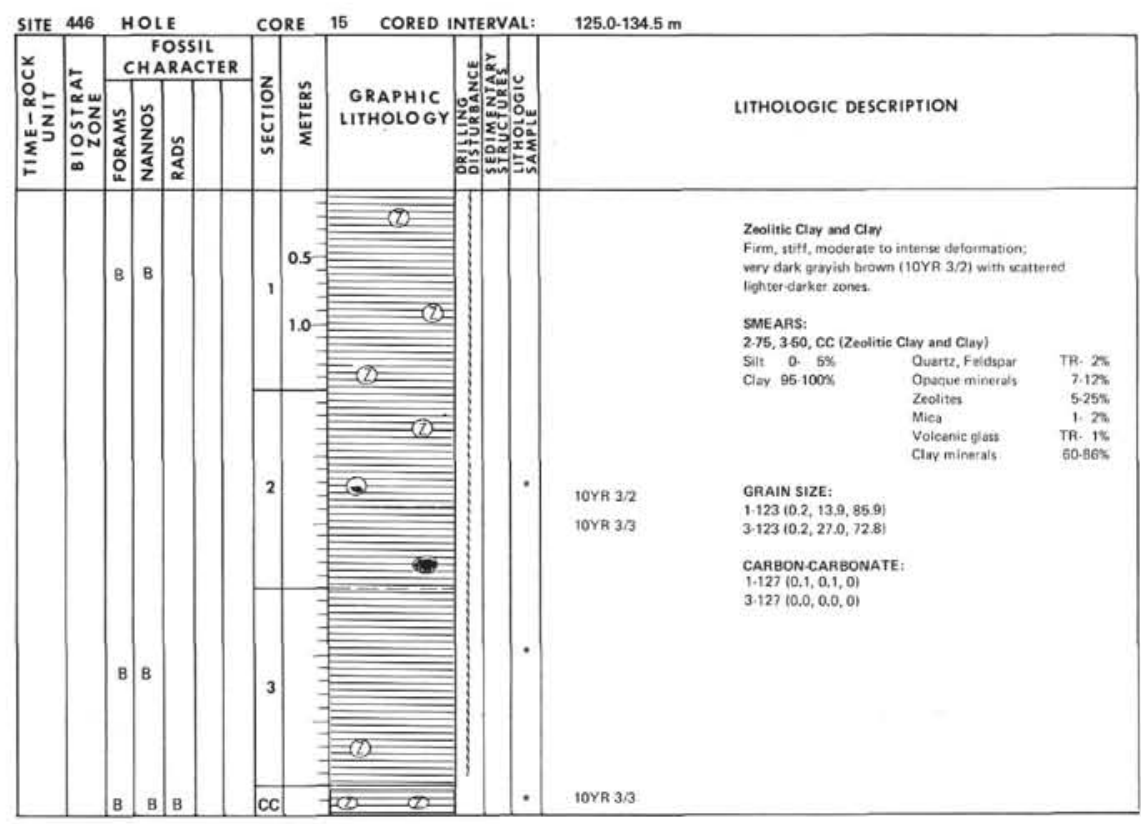




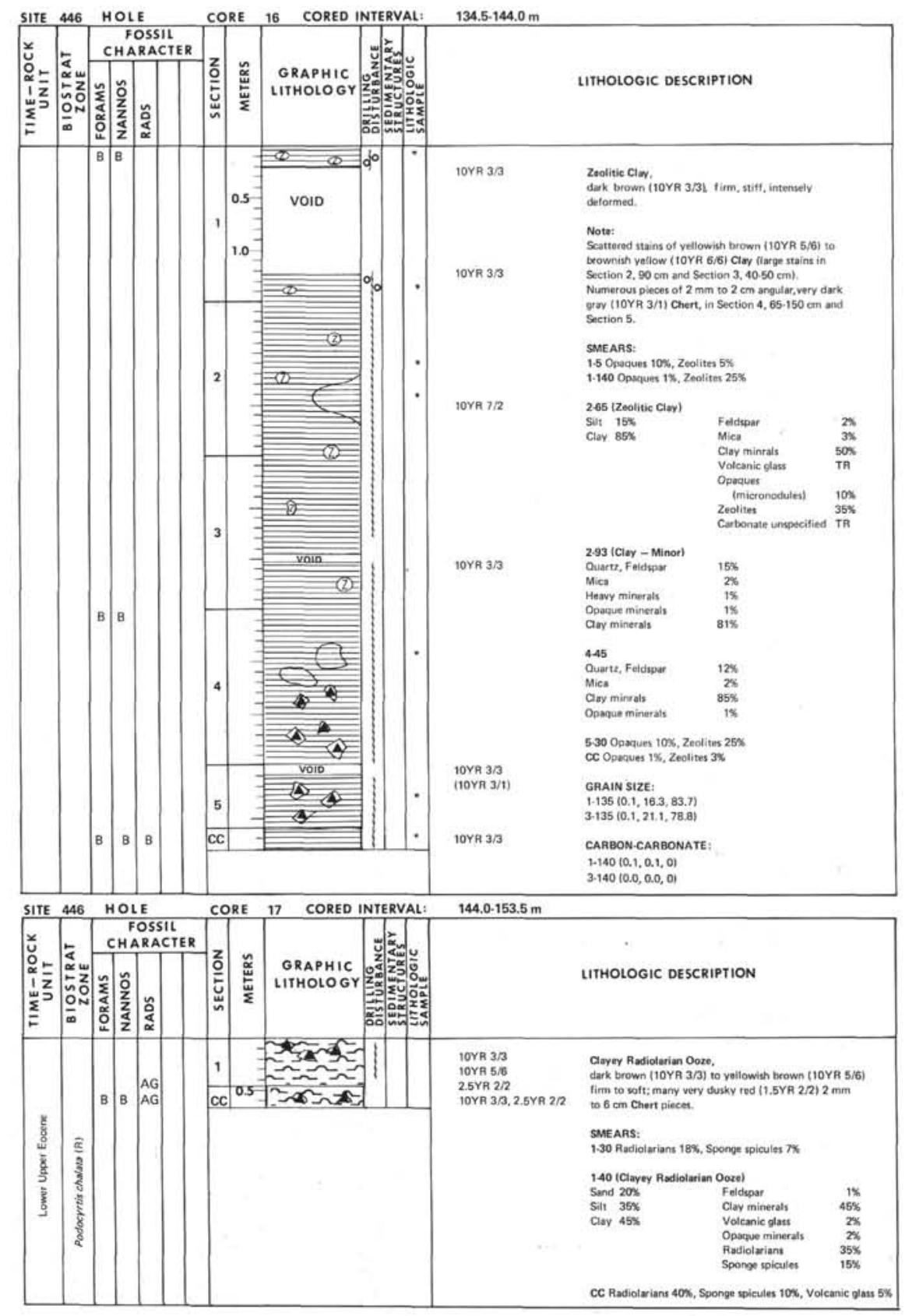

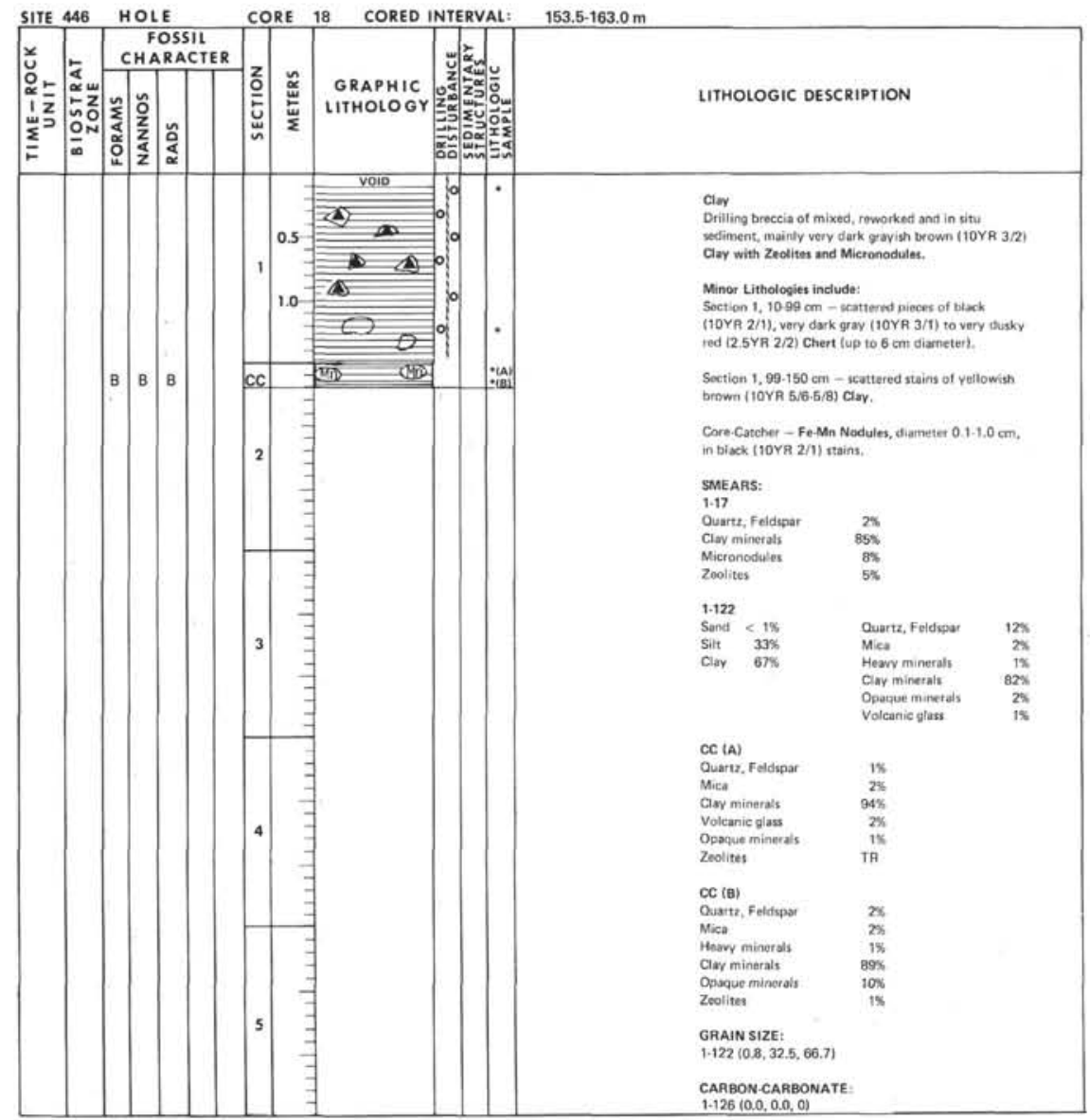



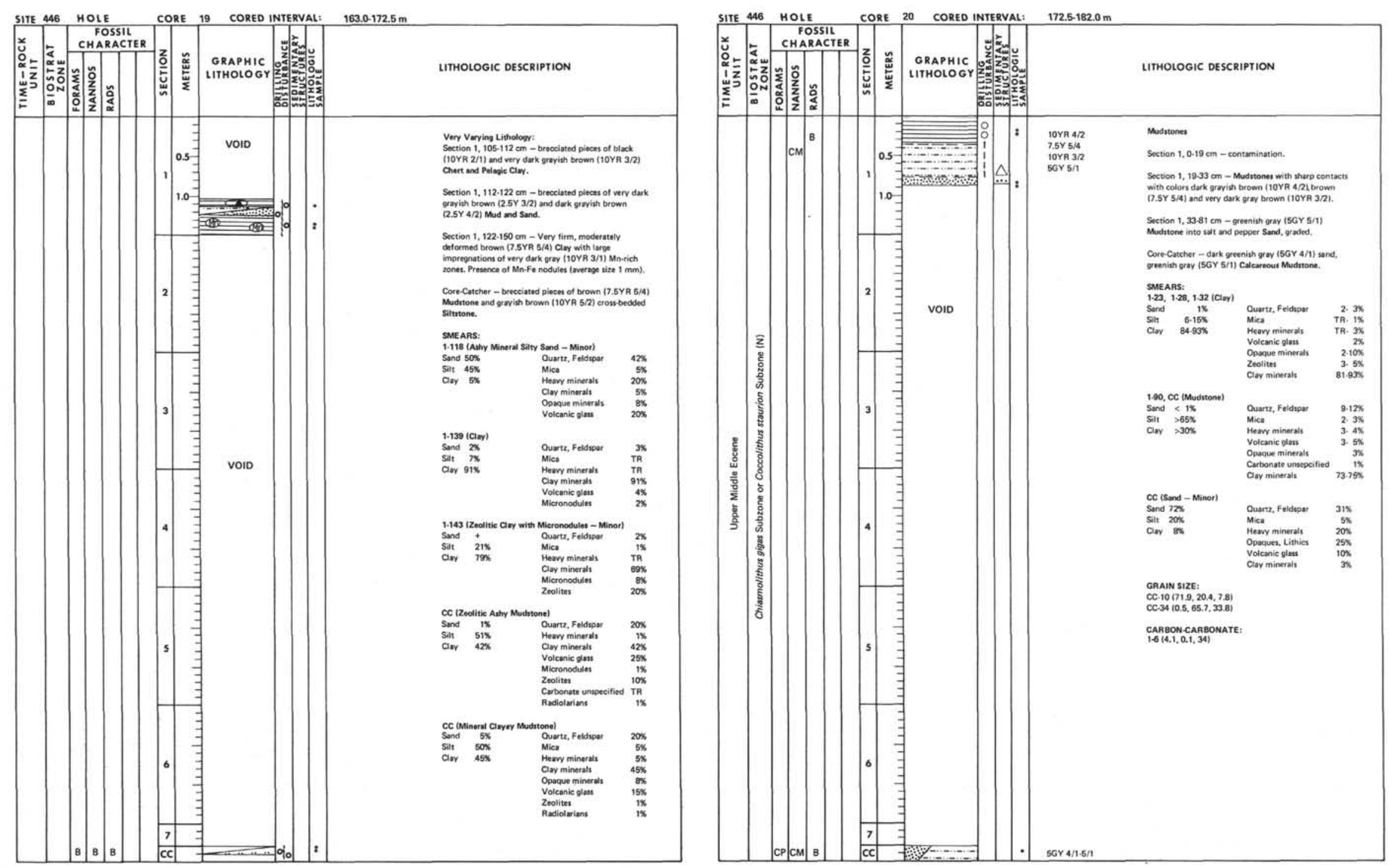


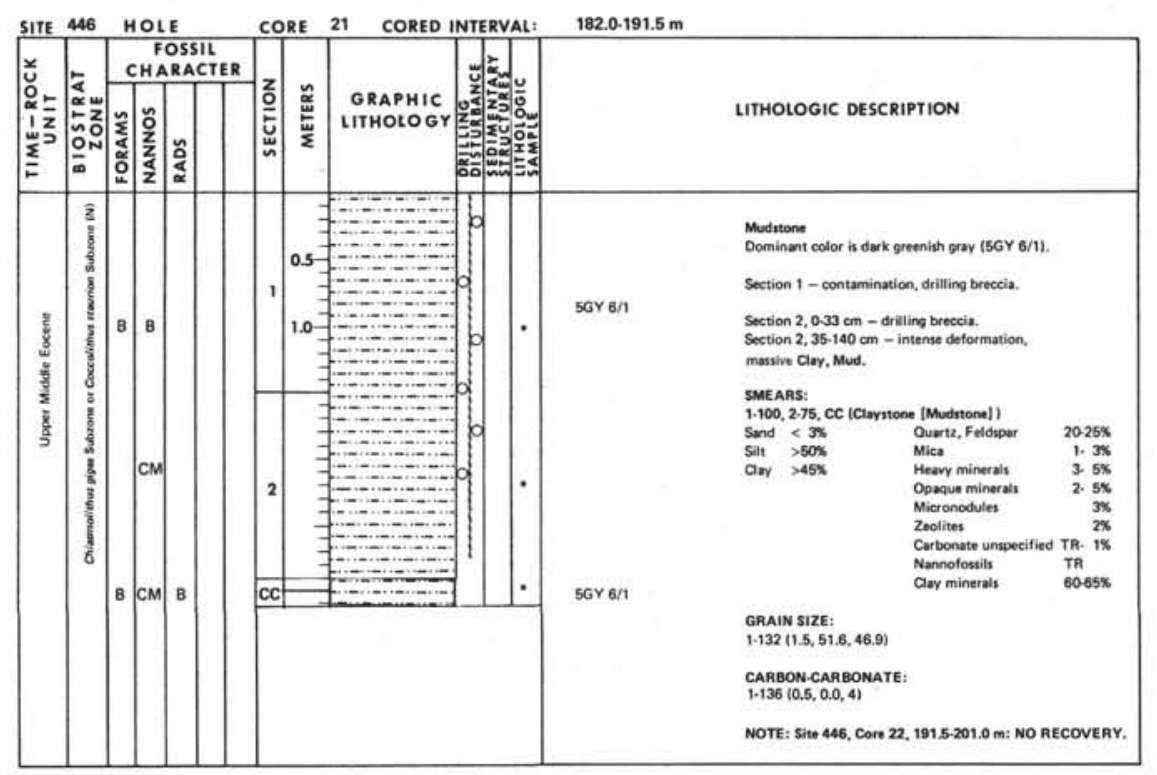

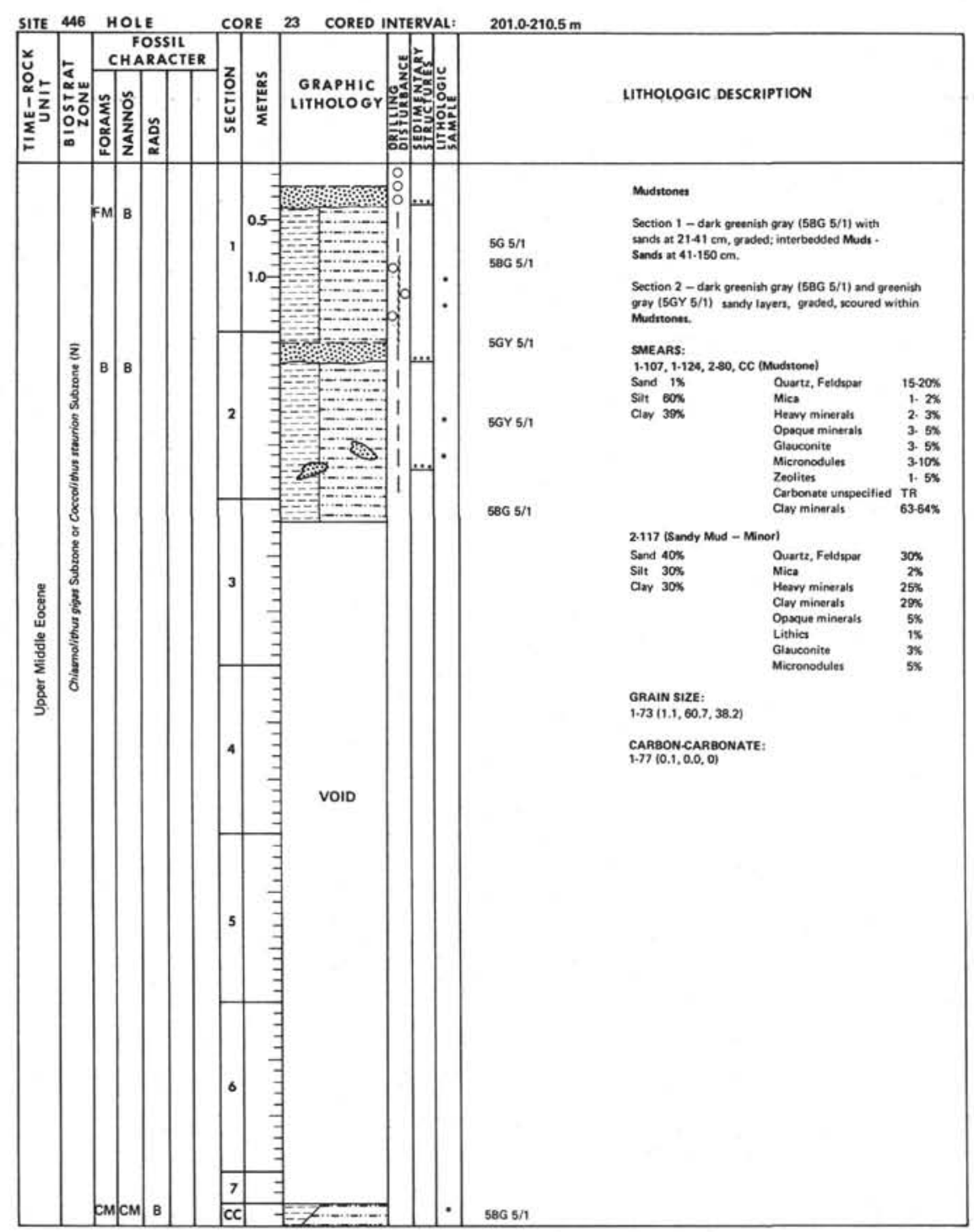




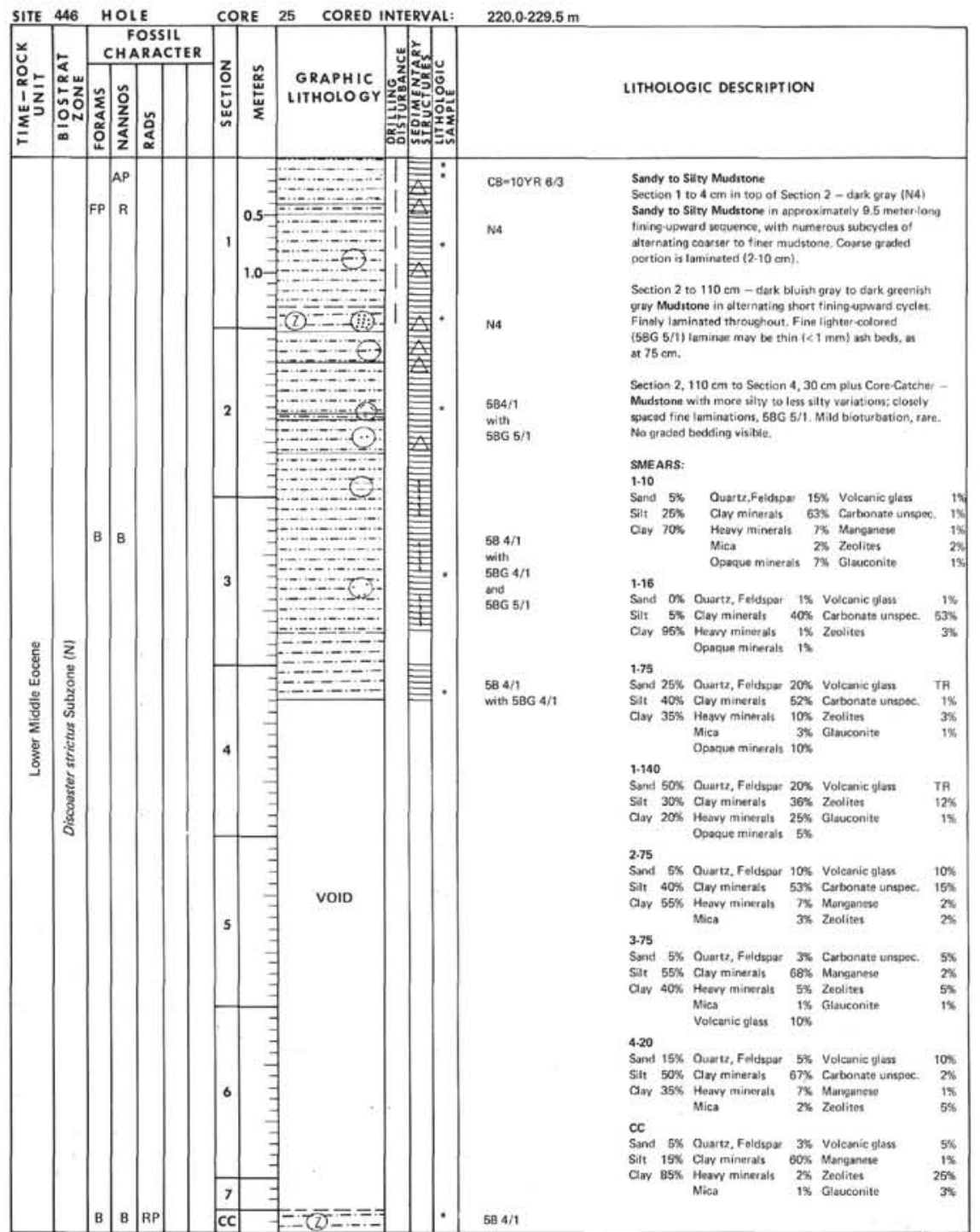



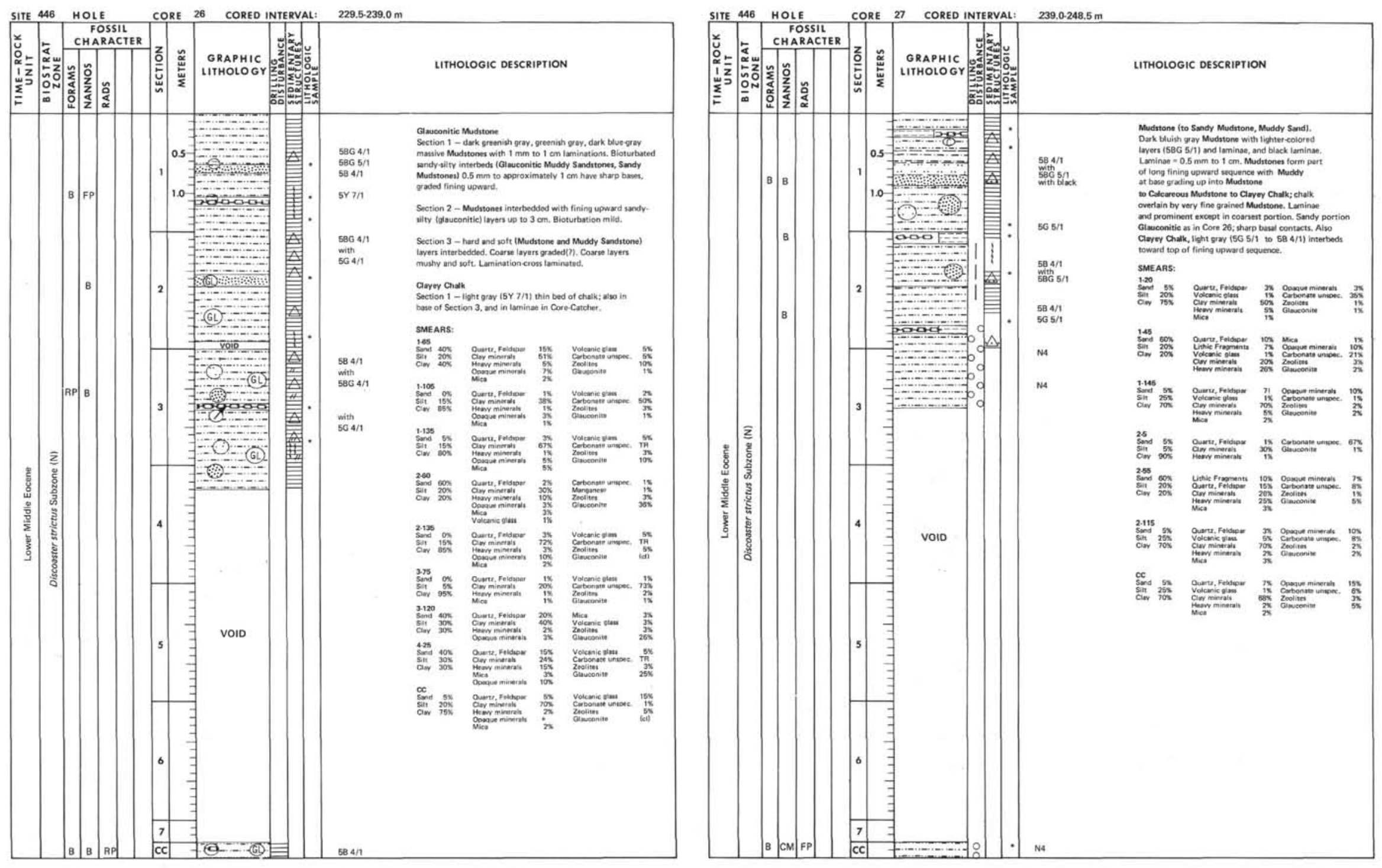

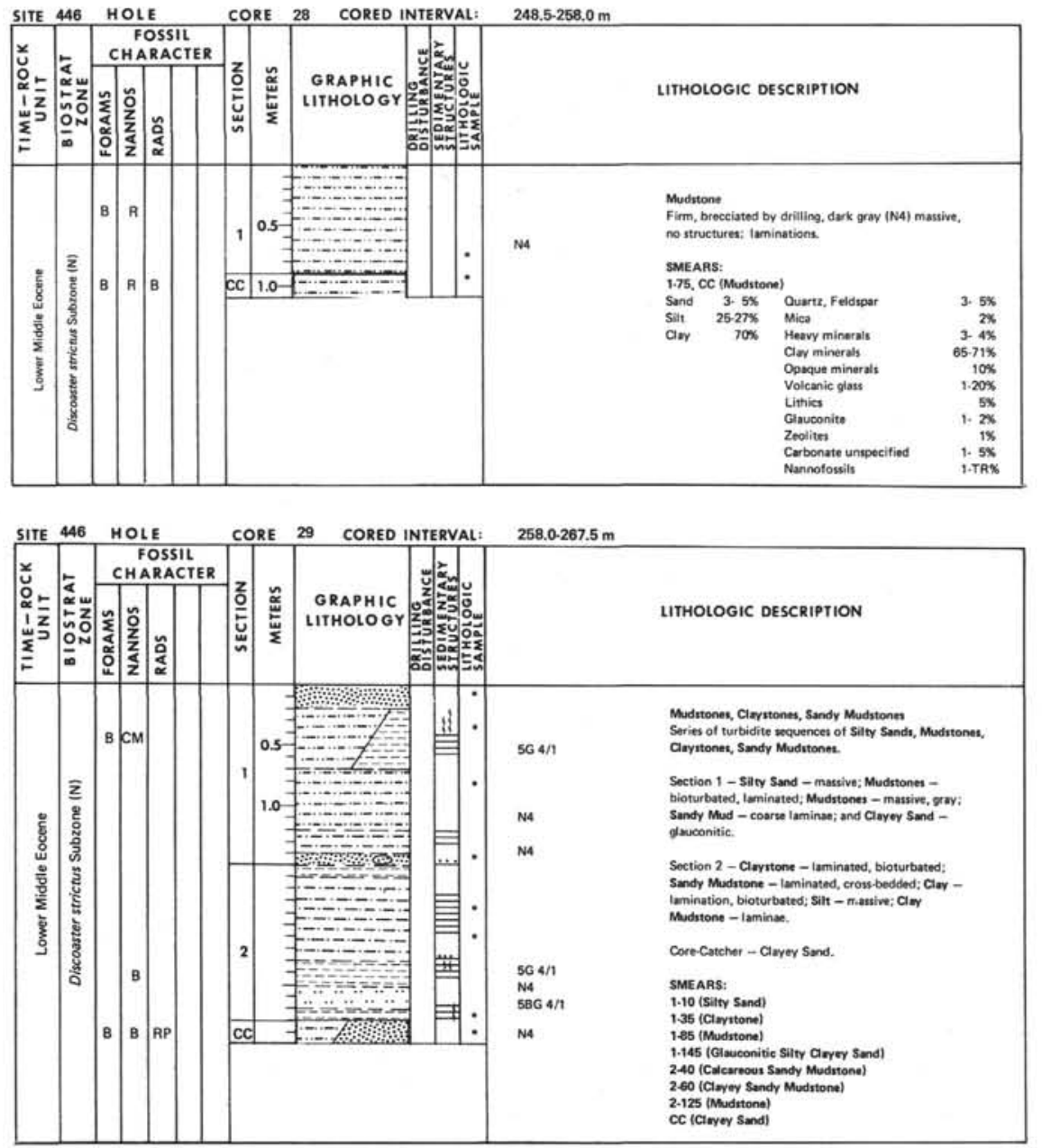

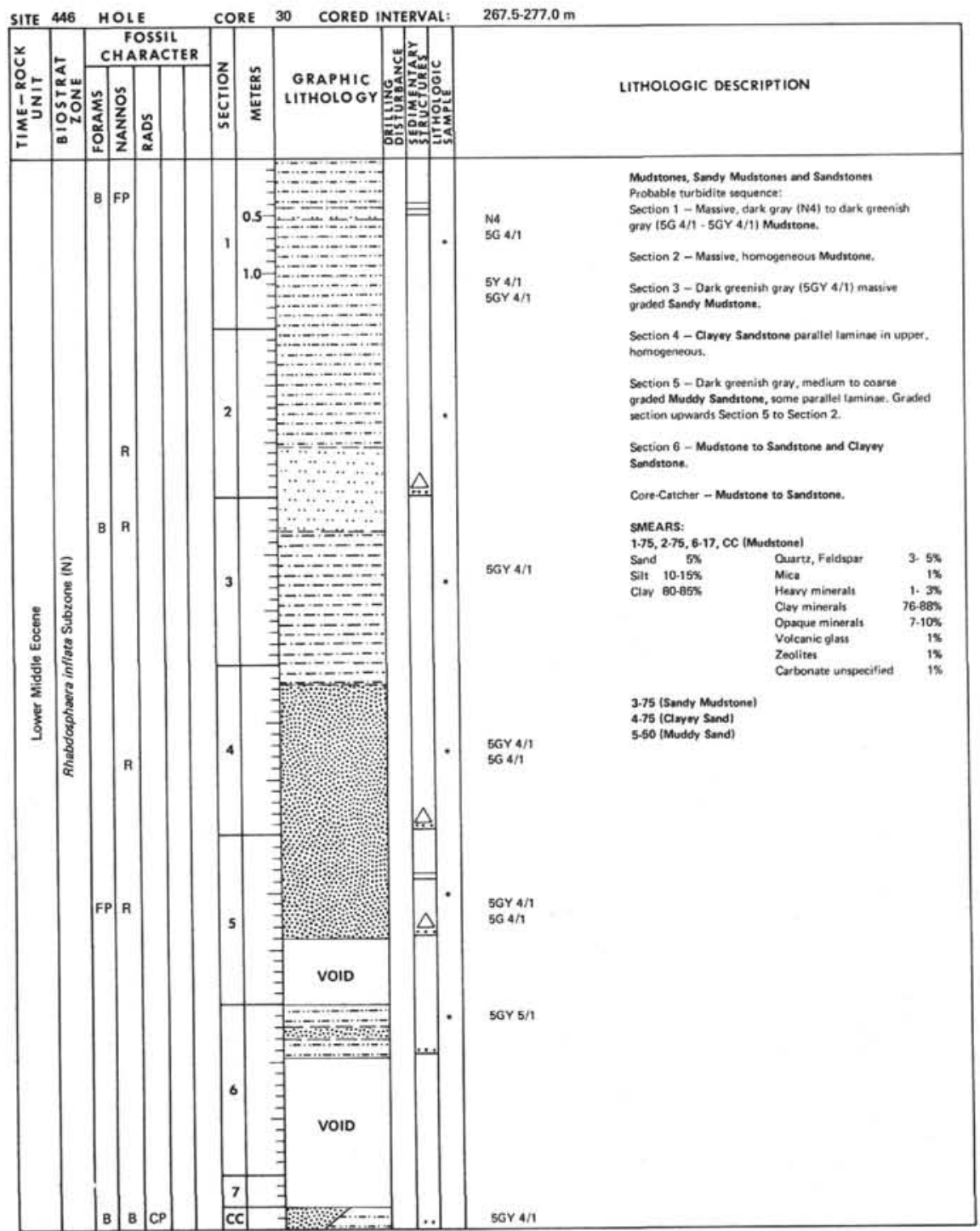




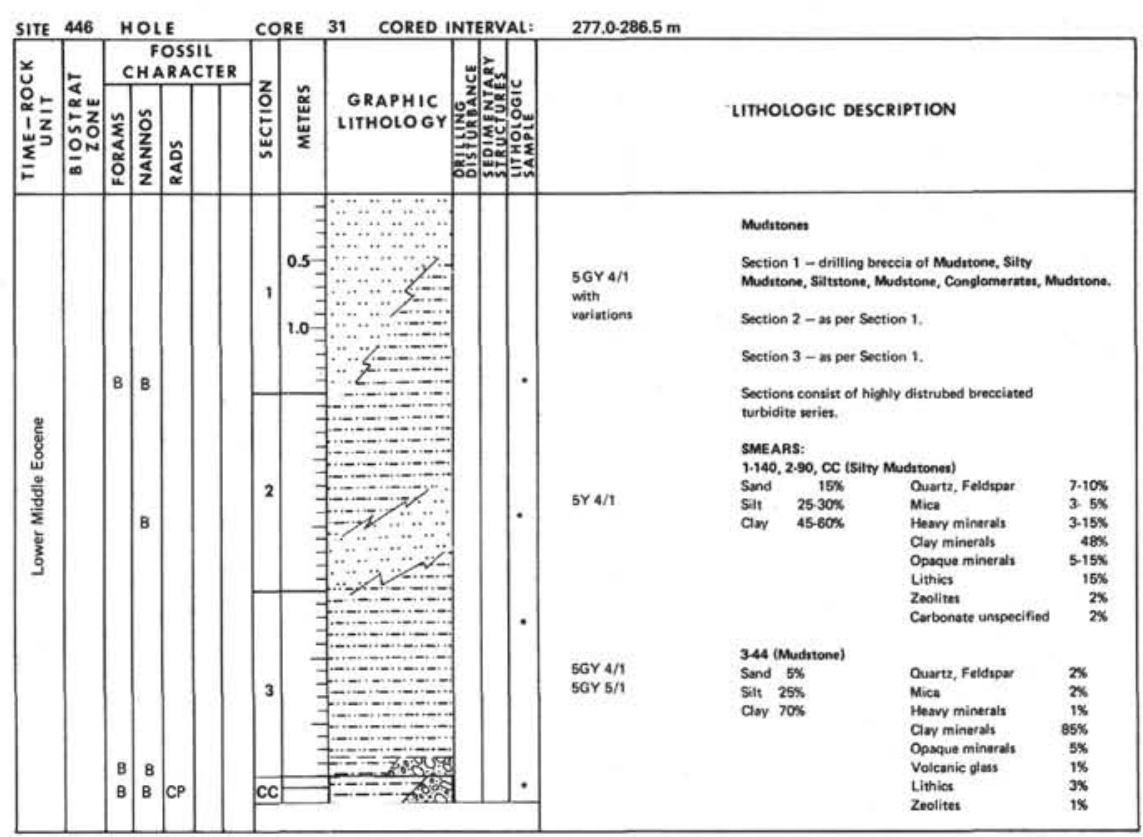




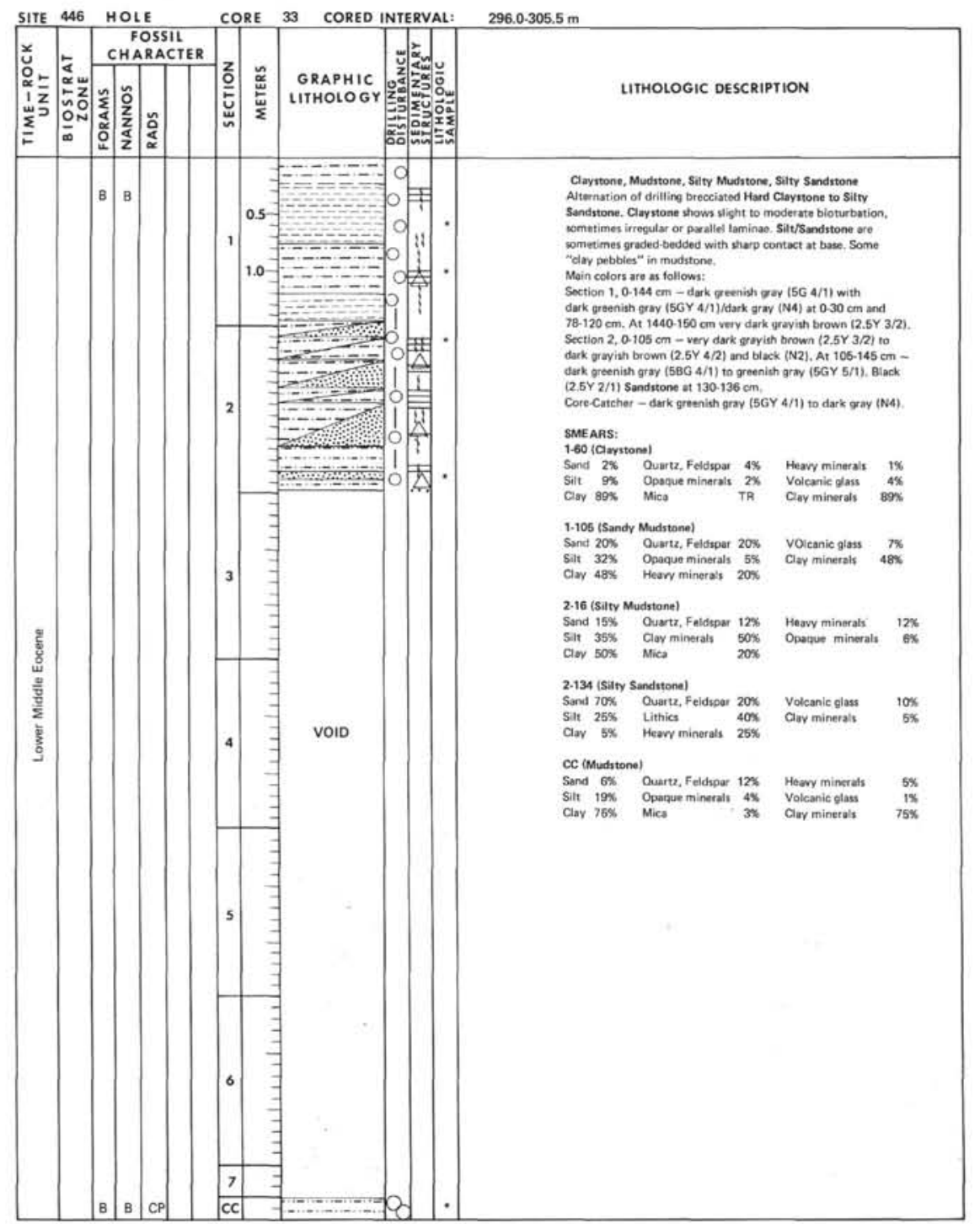

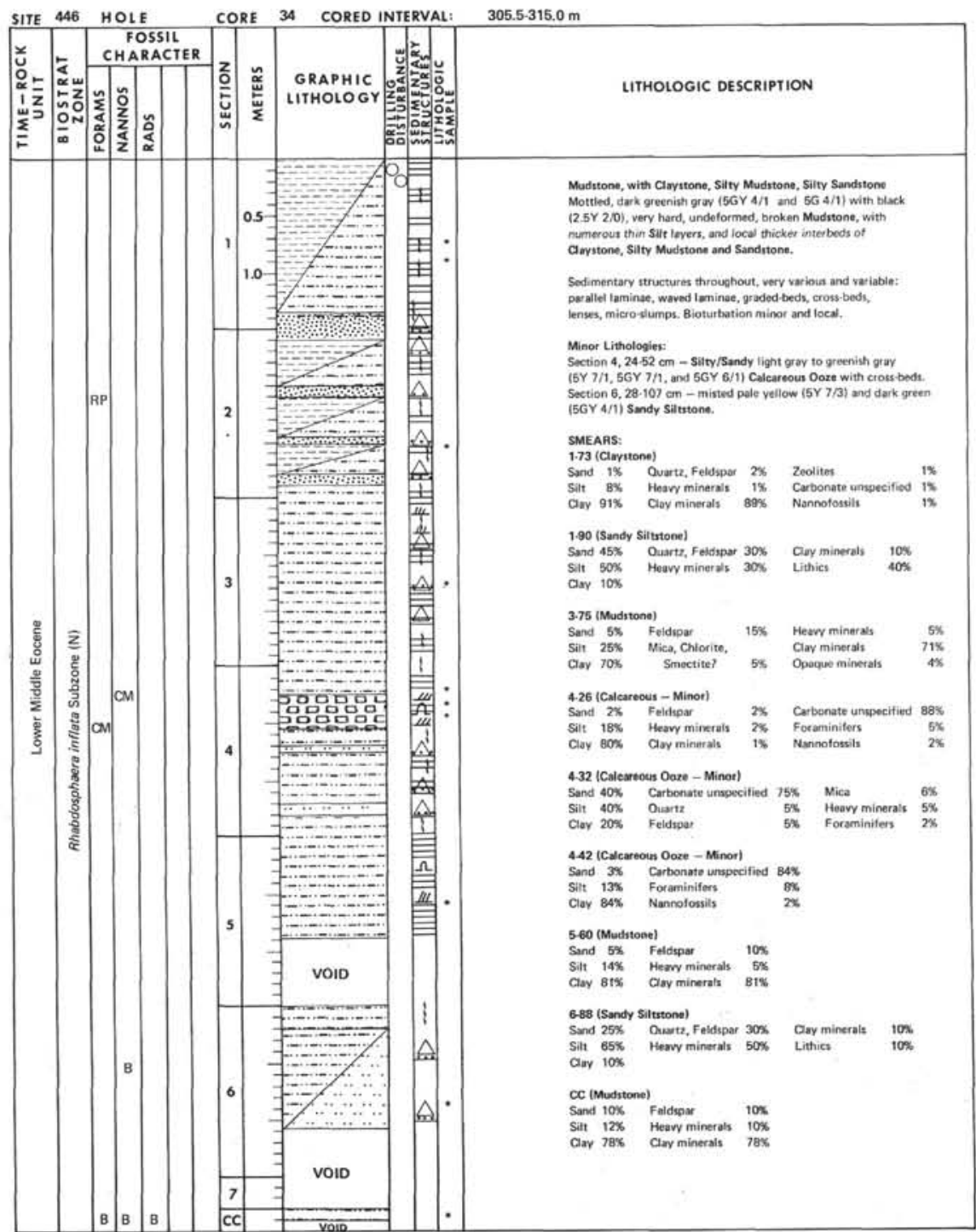



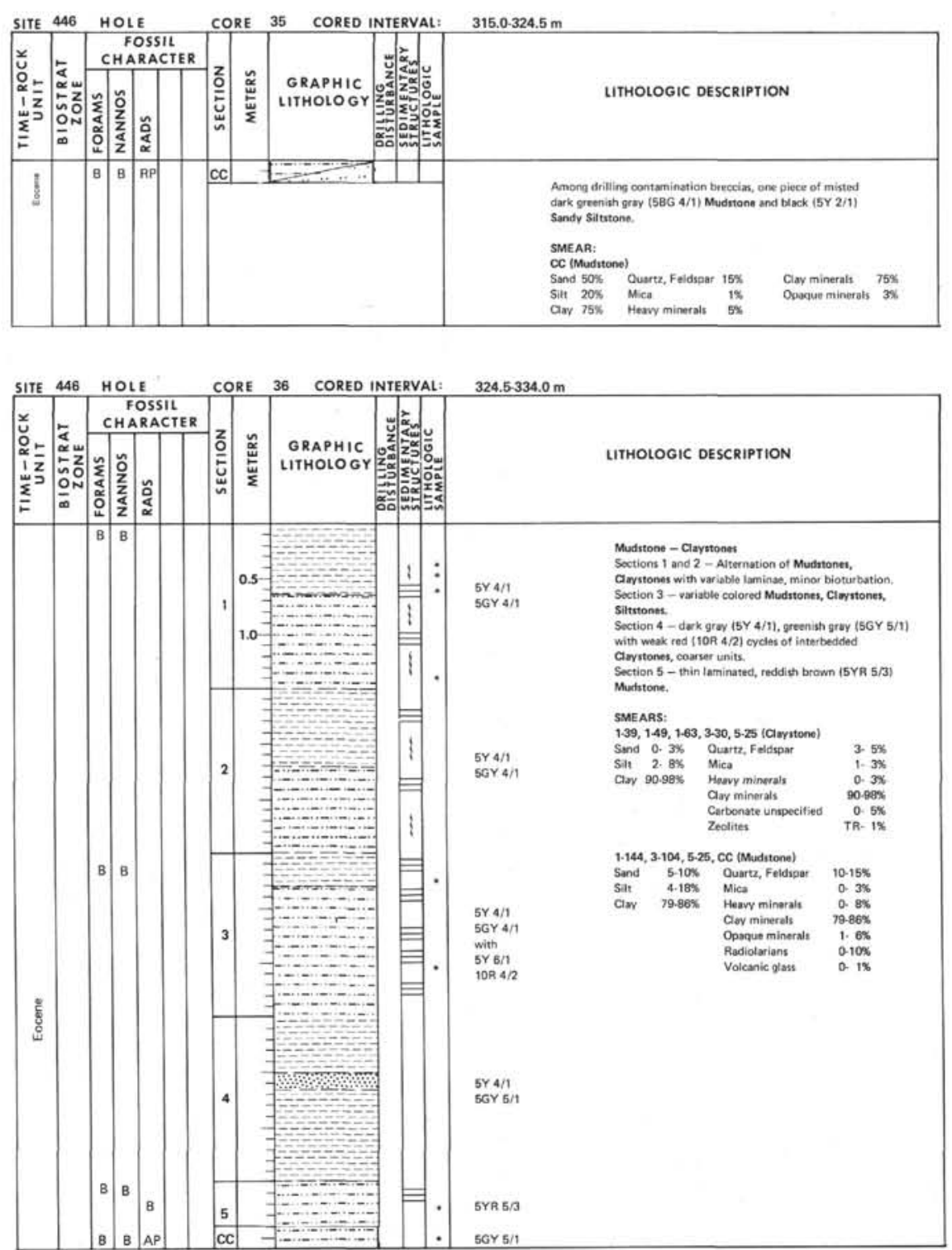

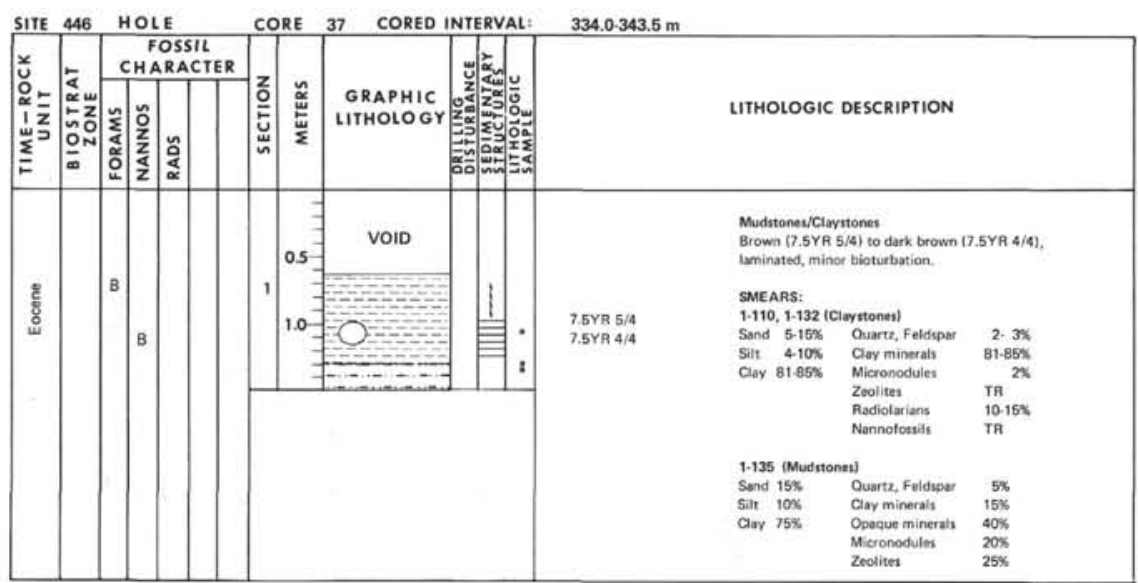



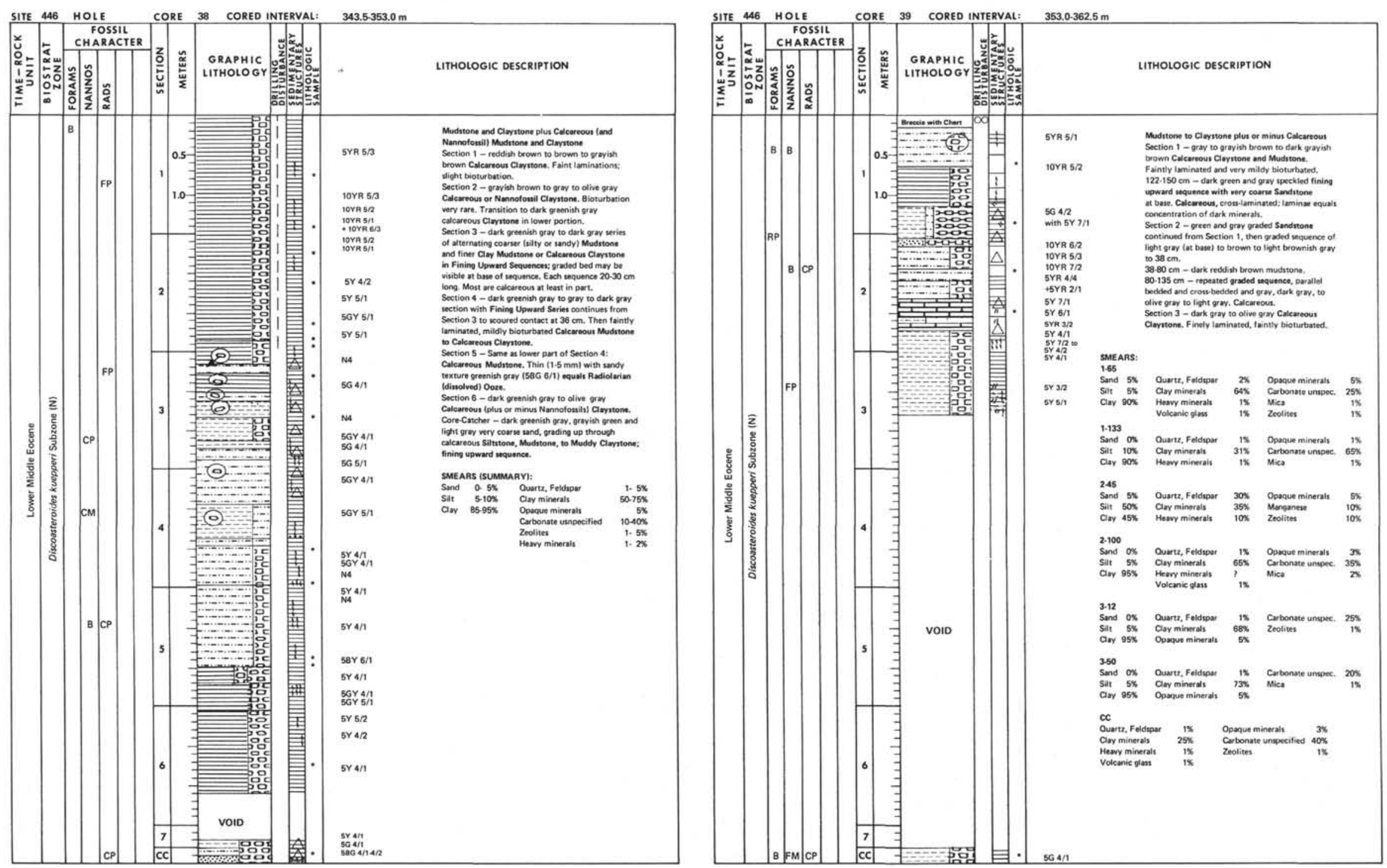

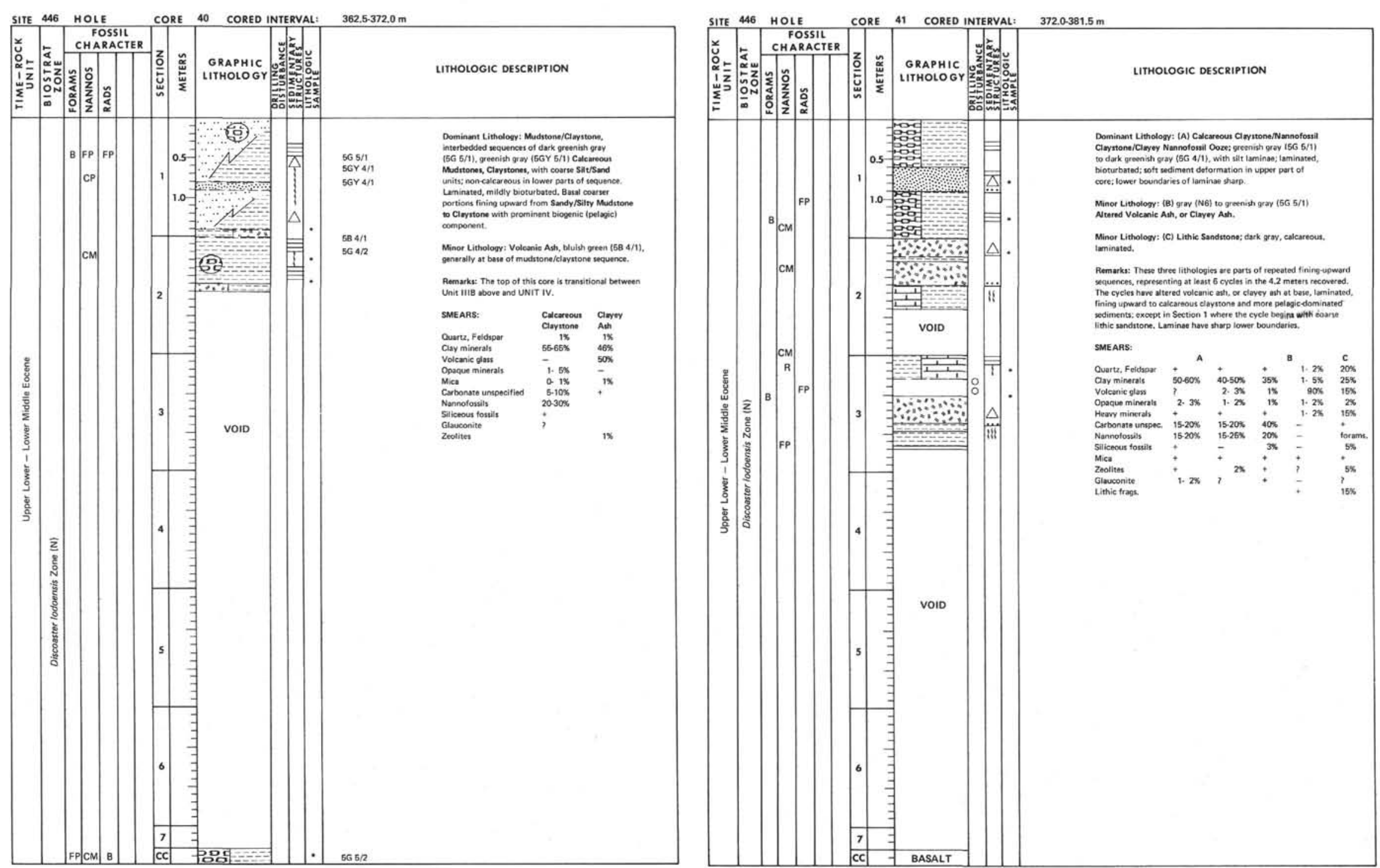


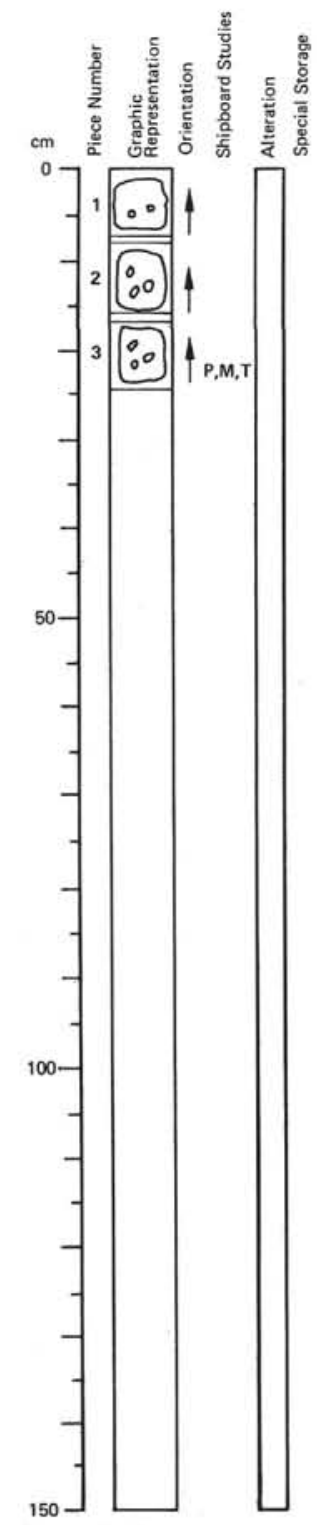

\section{VISUAL CORE DESCRIPTION
FOR IGNEOUS ROCKS

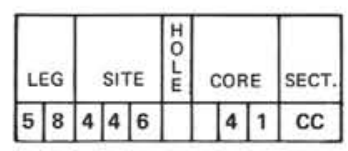

Visual Description

Vesicles lined by calcite, zeolites (tabular-heulandine pyrrohotite).

Piece 1: 5 .

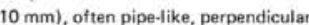
to hole orientation).

\section{Thin Section Description - $19 \mathrm{~cm}$}

Groundmass: plagioclase $25 \%, 0.110 .75 \mathrm{~mm}$, An 70 , carlsbad-An content; clinopyroxene .

Tescles: $20 \%, 0.1-1.0 \mathrm{~mm}$, calcite ( $-6 \%)$, irregular.

Alteration: $3 \%$ carbonate in vesicles, often euhedral.

Shipboard Data
Bulk Analysis:

\begin{tabular}{|c|c|c|c|}
\hline Bulk Analysis: & $20 \mathrm{~cm}$ & Magnetic Data: & \\
\hline & 47.76 & Intensity (emu/cc) & 86.6 \\
\hline $\mathrm{Al}_{2} \mathrm{O}_{3}$ & 13.62 & Inclination before & \\
\hline $\begin{array}{l}\mathrm{Fe}_{2} \mathrm{O}_{3} \\
\mathrm{FeO}\end{array}$ & 1.21 & & -55.7 \\
\hline $\begin{array}{l}\begin{array}{l}\text { Fế } \\
\text { MgO }\end{array} \\
\end{array}$ & $\begin{array}{l}7.99 \\
464\end{array}$ & Stable Inclination & -47.1 \\
\hline $\mathrm{CaO}$ & $\begin{array}{r}41.64 \\
11.46\end{array}$ & Physical Properties: & $22 \mathrm{~cm}$ \\
\hline $\mathrm{Na}_{2} \mathrm{O}$ & 3.23 & $\overline{V_{p}}(\mathrm{~km} / \mathrm{s})$ & \\
\hline & 2.65 & Porosity (\%) & \\
\hline $\mathrm{TiO}_{2}$ & 3.58 & Wet Bulk Density & $\begin{array}{l}2.62 \\
2.99\end{array}$ \\
\hline
\end{tabular}

$\begin{array}{llll} & & & \\ \mathrm{TiO}_{2} & 3.58 & \text { Wet Bulk Density } & 18.42 \\ \mathrm{P}_{2} \mathrm{O}_{5} & 0.36 & \text { Grain Density } & 2.92 \\ & 0.36 & & \end{array}$

$101-0.32$

$\begin{array}{ll}\mathrm{C}_{2} \mathrm{O}^{+} \\ \mathrm{O}_{2} \mathrm{O}^{-} \\ \mathrm{CO}_{2} & = \\ \mathrm{CH}^{2} & -\end{array}$

$\mathrm{CO}^{2} \quad-\quad-39.00$

$\begin{array}{lr}\mathrm{Cr} & 39.00 \\ \mathrm{Ni} & 28.00 \\ \mathrm{Si} & 693.00 \\ \mathrm{Zr} & 210.00\end{array}$

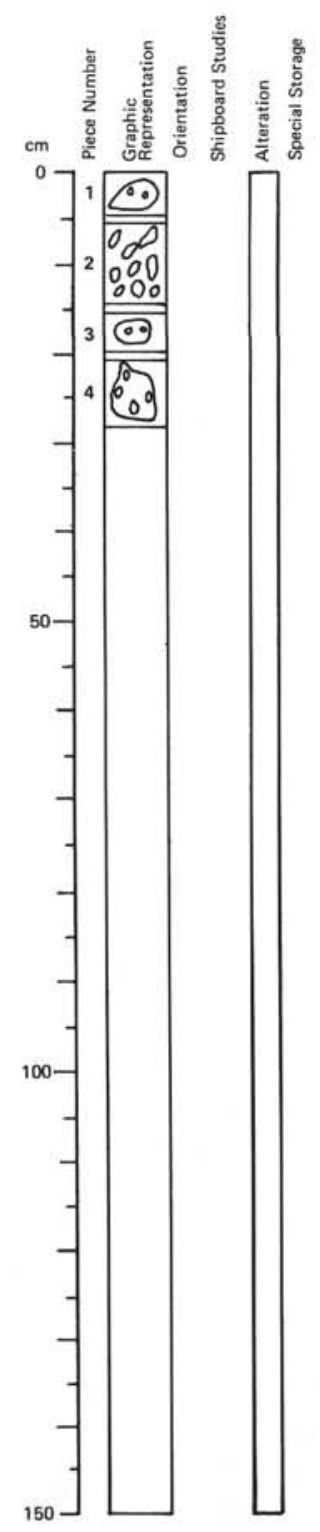
VISUAL CORE DESCRIPTION

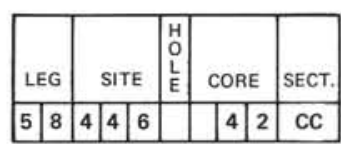

Depth: 381.5 to $381.78 \mathrm{~m}$

Visual Description

ar, aphyric, aphanitic basalt

1: $5.10 \%$ vesicles $\{<1 \mathrm{~mm}$

Pece 3: $8 \%$ vesicles $(<1 \mathrm{~mm}), 2 \%$ vesicles $(1-2 \mathrm{~mm})$.

.

Similar to previous section.

Thin Section Description - $17 \mathrm{~cm}$

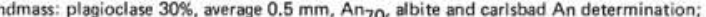
政, proxene; other apatite $<1 \%$.

Alteration: $1 \%$ carbonate in vesicles; other chlorite $2 \%$, in groundmass

Shipboard Data
Bulk Analysiss

Bulk Analysis: $\quad 24 \mathrm{~cm}$

$\mathrm{SiO}_{2} \quad 46.97$

$\begin{array}{lr}\mathrm{Al}_{2} \mathrm{O}_{3} & 13.32 \\ \mathrm{Fe}_{2} \mathrm{O}_{3} & 1.30 \\ & 8.59\end{array}$

$\begin{array}{lr}\mathrm{MgO}_{\mathrm{M}} & \\ \mathrm{CaO} & 1.21 \\ \mathrm{Na}_{2} \mathrm{O} & 3.69 \\ \mathrm{~K}_{2} \mathrm{O} & 3.25\end{array}$

2.28

$\begin{array}{lll}\mathrm{T}_{1} \mathrm{O}_{2} & 3.54 \\ \mathrm{P}_{2} \mathrm{O}_{5} & 3.35 \\ \mathrm{~T}_{2} & 0.35\end{array}$

$\begin{array}{lll}-101 & -34\end{array}$

$\mathrm{H}_{2} \mathrm{H}_{2} \mathrm{O}^{+}=$

-18.00
$\mathrm{CO}_{2}$

$\begin{array}{lr}\mathrm{Cr}_{\mathrm{r}} & 18.00 \\ \mathrm{Ni} & 29.00 \\ \mathrm{Sr} & 689.90 \\ \mathrm{Zr} & 206.00\end{array}$ 


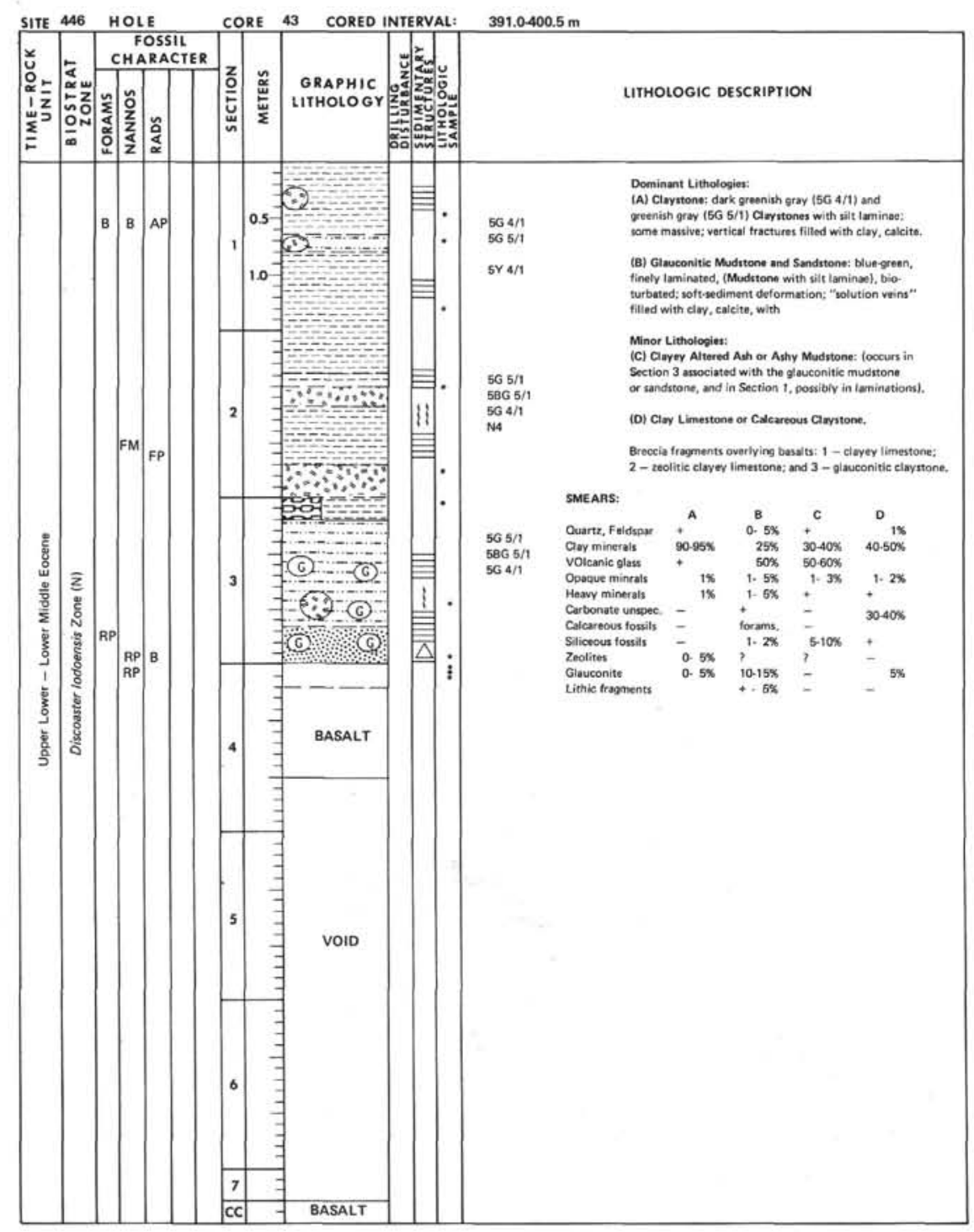




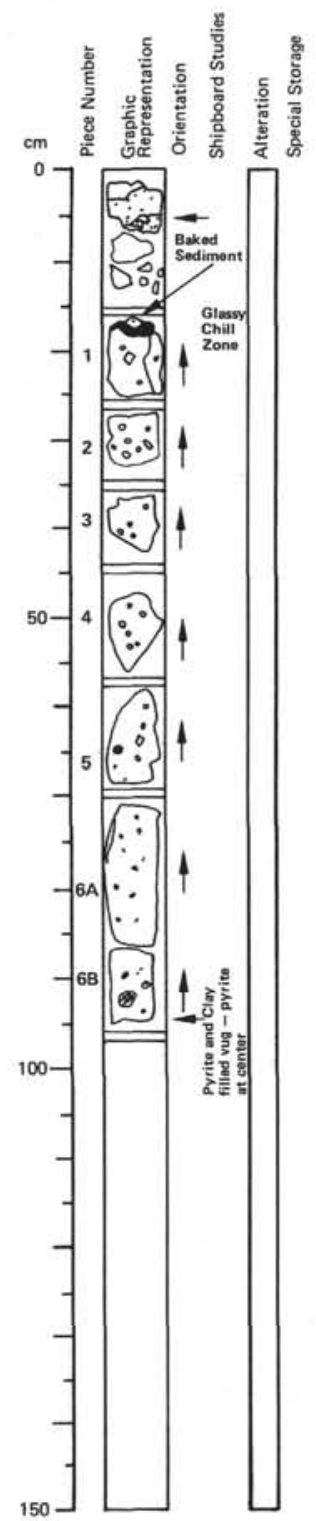

VISUAL CORE DESCRIPTION
FOR IGNEOUS ROCKS

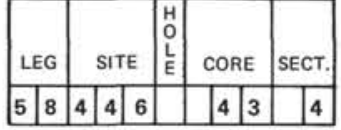

Depth: 395.5 to $396.5 \mathrm{~m}$

Visual Description

ceren to brown clay and sandstone, hard and indurated compared to sediment higher in core.

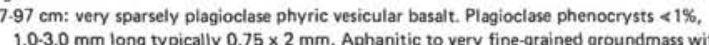
elty plagioclase laths $1.0 \mathrm{~mm}$ and less (acicular), randomly oriented as incipient groundma crystallization. Alteration occurs largely in vesicles which are largely clay and pyrite filled amygaules. Amygdules 5-10\%, 0.5 to $3.0 \mathrm{~mm}$ across. Clay minerals and pyrites often top to fine-grained basalt at base of this section. $17.26 \mathrm{~cm}$ : glassy chill zone grading from baked clay mis (partially devitrified) to aphanitic to fine-grained basalt. Glass is filled to $1 \mathrm{~cm}$ of glass plagioclase lathes.

Thin Section Description $-4 \cdot 21 \mathrm{~cm}$

. An 15\%, $0.05-1.0 \mathrm{~mm}$, granules and laths; other $=$ grundage $25 \%$ mixture of clay and cryptocrystalline material.

Thin Section Description $-4.81 \mathrm{~cm}$

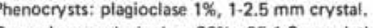

linopyroxene $16 \%, 05-1.0 \mathrm{~mm}$, granules and ins and skeletal crystals: other = arundage 33\%, mixture of smectite, chlorite(?) and clay minerals and cryptocrystalline material.

Vesicles: $7 \%, 0.5-4.0 \mathrm{~mm}$, clay filling, round.

Texture: intersertal.

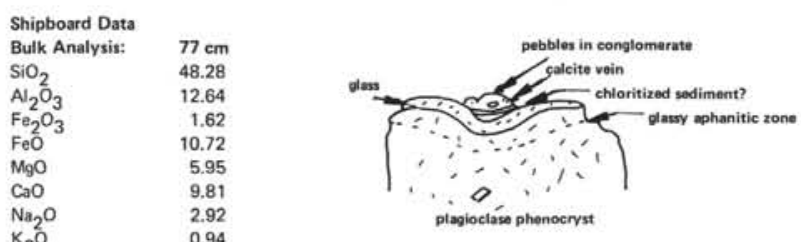

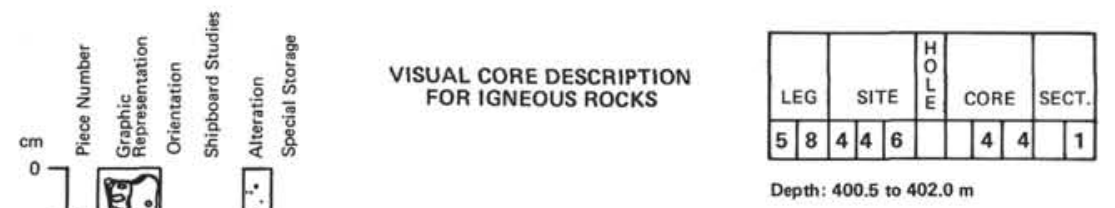

Visual Description

$0.150 \mathrm{~cm}$ : fine-grained, light to moderate alteration. Amygdaloidal with clav. calcite and pyrite fillings, 0 to $3 \%$ amygdules $0.5-5.0 \mathrm{~mm}$.

$44.137 \mathrm{~cm}$ : continuous clastic dike. Upper portion of dike is with calcite replacing sediment. Lower portion has clastic breccia retaining its original appearance and texture with clay matrix.

Shipboard Data

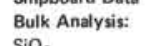

$\mathrm{SiO}_{2}$
$\mathrm{Al}_{2} \mathrm{O}_{3}$
$\mathrm{Fe}_{2} \mathrm{O}_{3}$

$\mathrm{FeO}_{2}$

$\mathrm{MaO}$
$\mathrm{CaO}$

$\mathrm{CaO}$
$\mathrm{Na}_{2} \mathrm{O}$
$\mathrm{K}_{2} \mathrm{O}$

$\mathrm{Na}_{2} \mathrm{O}$
$\mathrm{K}_{2} \mathrm{O}$
$\mathrm{TiO}_{2}$
$\mathrm{P}_{2} \mathrm{O}$

$\mathrm{TiO}_{2}$
$\mathrm{P}_{2} \mathrm{O}_{5}$
$\mathrm{MnO}$

$\mathrm{P}_{2} \mathrm{MnO}^{\mathrm{M}}$
$\mathrm{LOI}$
$\mathrm{H} \mathrm{O}_{2} \mathrm{O}$

$\mathrm{H}_{\mathrm{H}_{2} \mathrm{O}^{-}}=$

$\begin{array}{ll}\mathrm{CO}_{2} & - \\ \mathrm{Cr}^{2} & -\end{array}$

$\mathrm{Ni}$
$\mathrm{Ni}$
$\mathrm{r}$

$\begin{array}{ll}\mathrm{Zr} & 359.00 \\ & 275.00\end{array}$

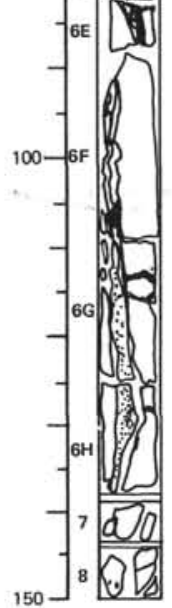

Magnetic Data:

Inclination before

demag.
Stable Inclination

Physical Proper

Grain Density

$\mathrm{cm}$

10.1
13.6

$6 \mathrm{~cm}$ 2.84 3.05 

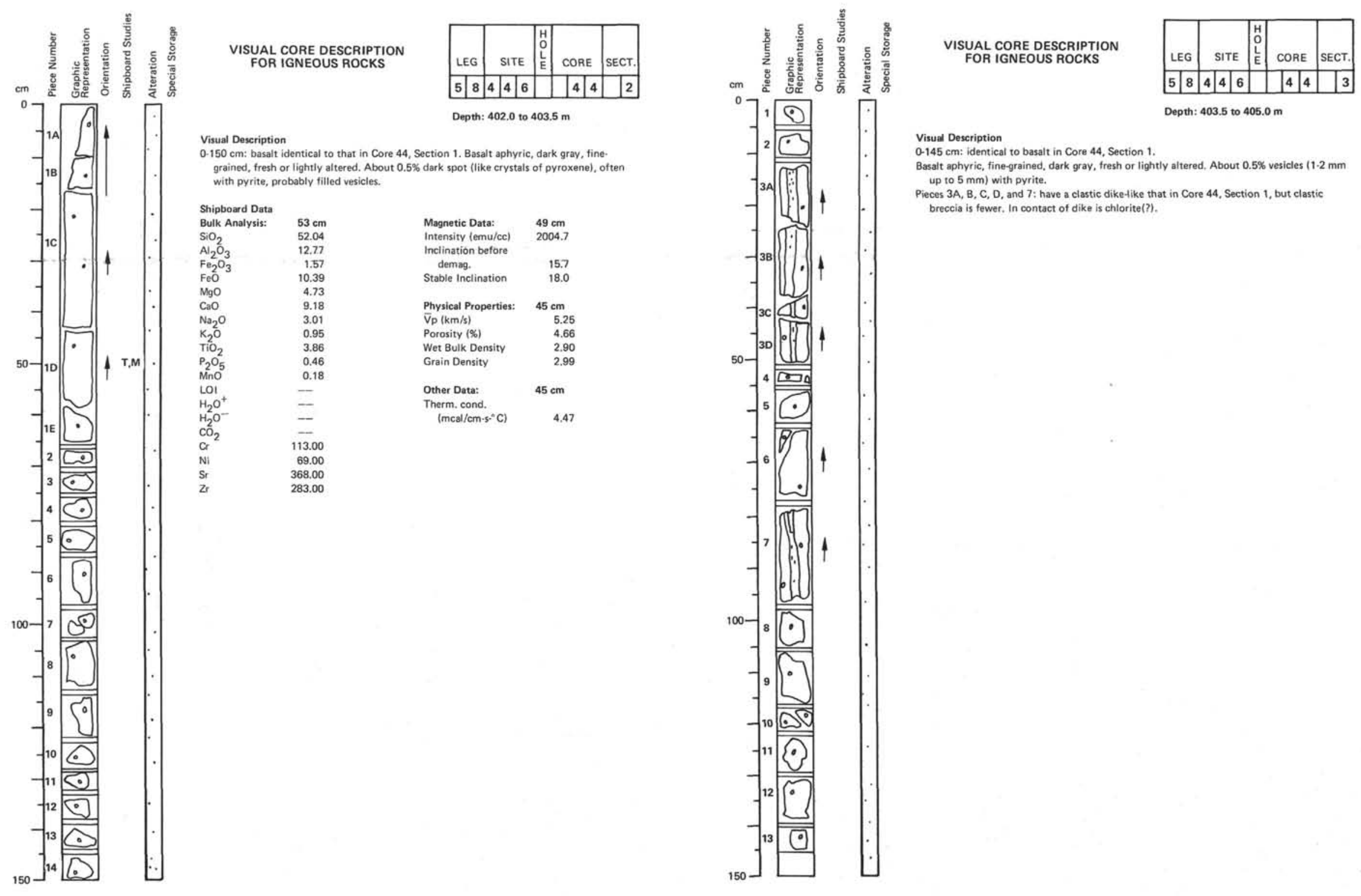

Visual Description
$0.145 \mathrm{~cm}$ : identical to basalt in Core 44 , Section 1 .

Basalt aphyric, fine-grained, dark gray, fresh or lightly altered, About $0.5 \%$ vesicles $11.2 \mathrm{~mm}$

up to $5 \mathrm{~mm}$ ) with pyrite.
Pieces $3 \mathrm{~A}, \mathrm{~B}, \mathrm{C}, \mathrm{D}$, and 7 : have a clastic dike-like that in Core 44 , Section 1 , but clastic breccia is fewer. In contact of dike is chlorite(?). 

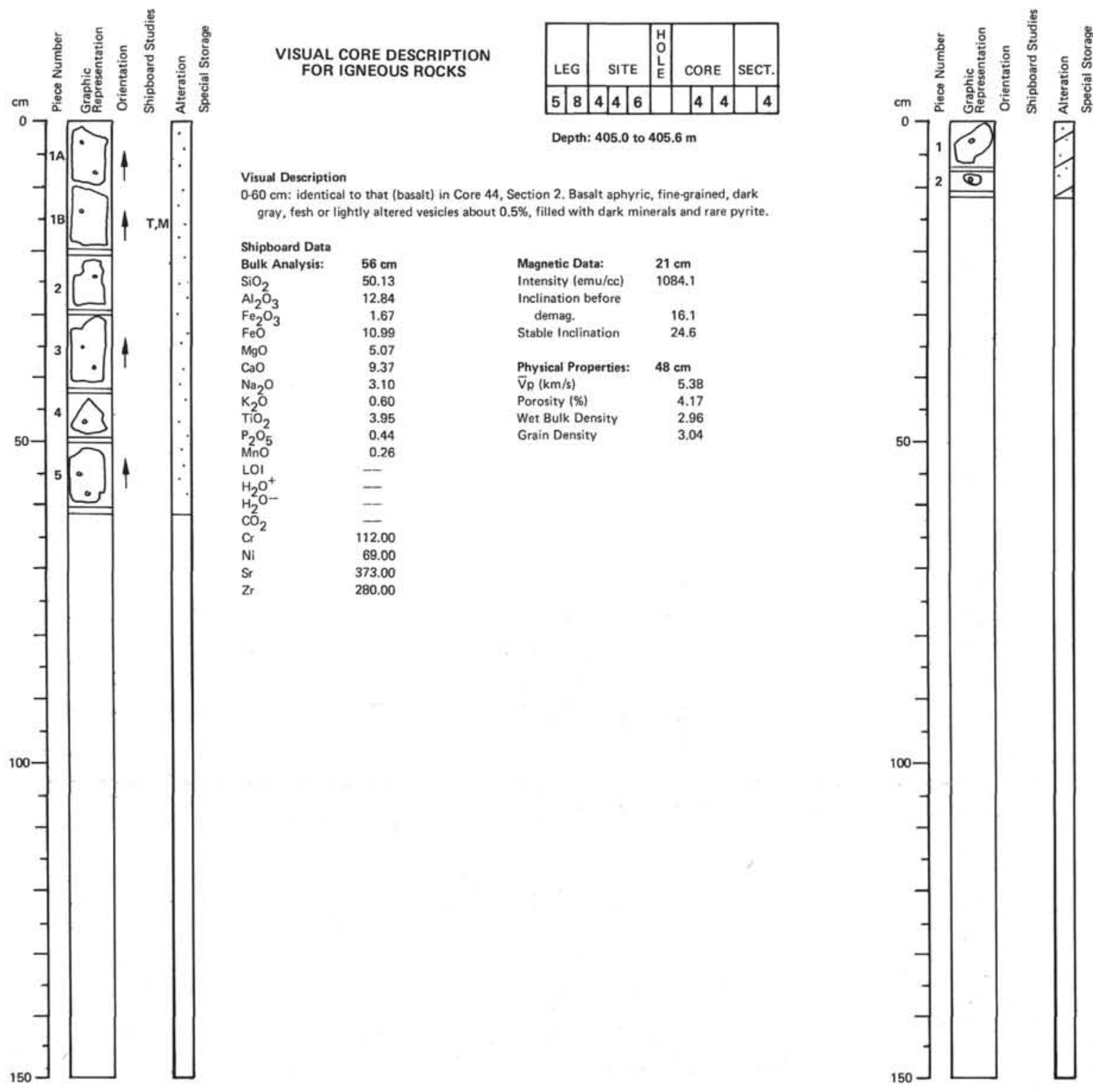

VISUAL CORE DESCRIPTION
FOR IGNEOUS ROCKS

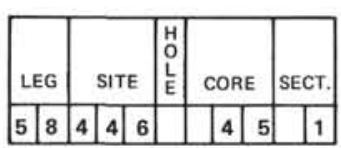

Depth: 410.0 to $410.1 \mathrm{~m}$

Visual Description $0.11 \mathrm{~cm}$ : basalt aphyric, fine-grained, dark gray, Vesicles $<0.5 \%$, filled with calcite (size approximately $2 \mathrm{~mm}$ ). 


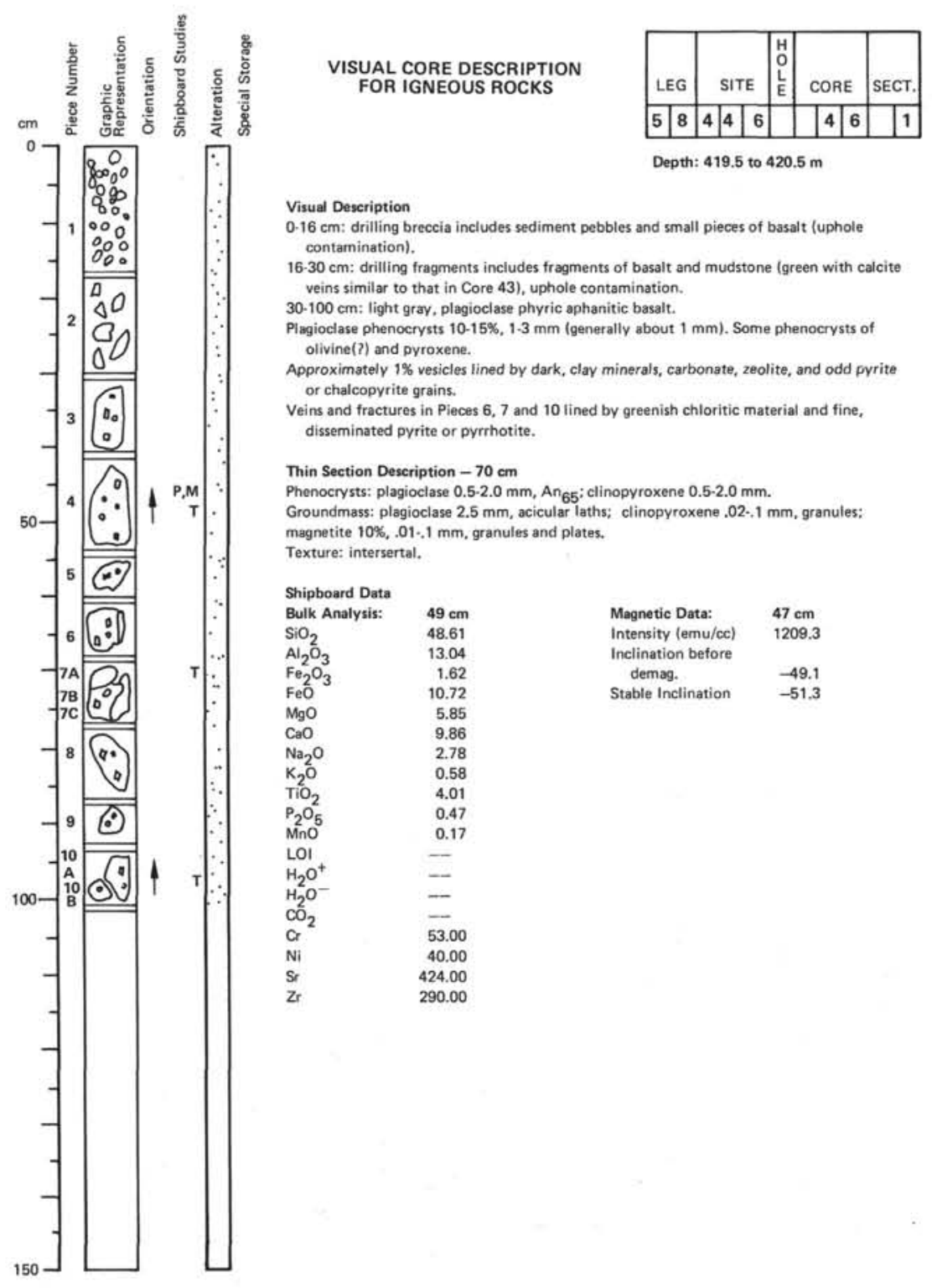




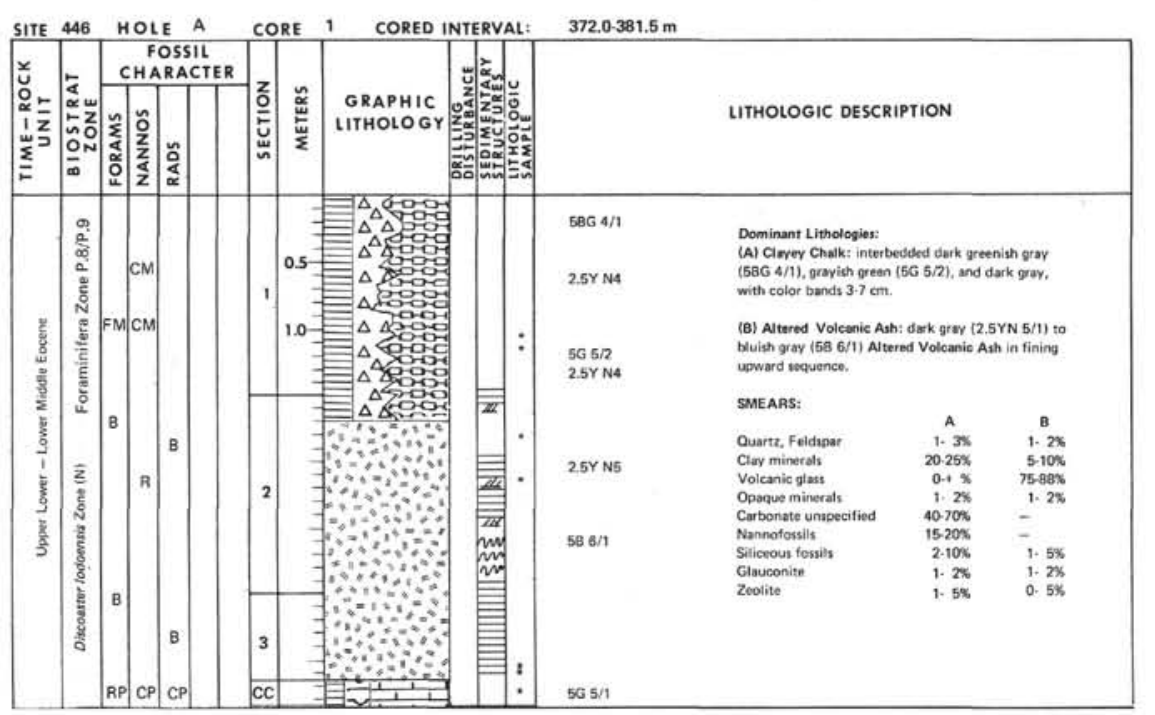

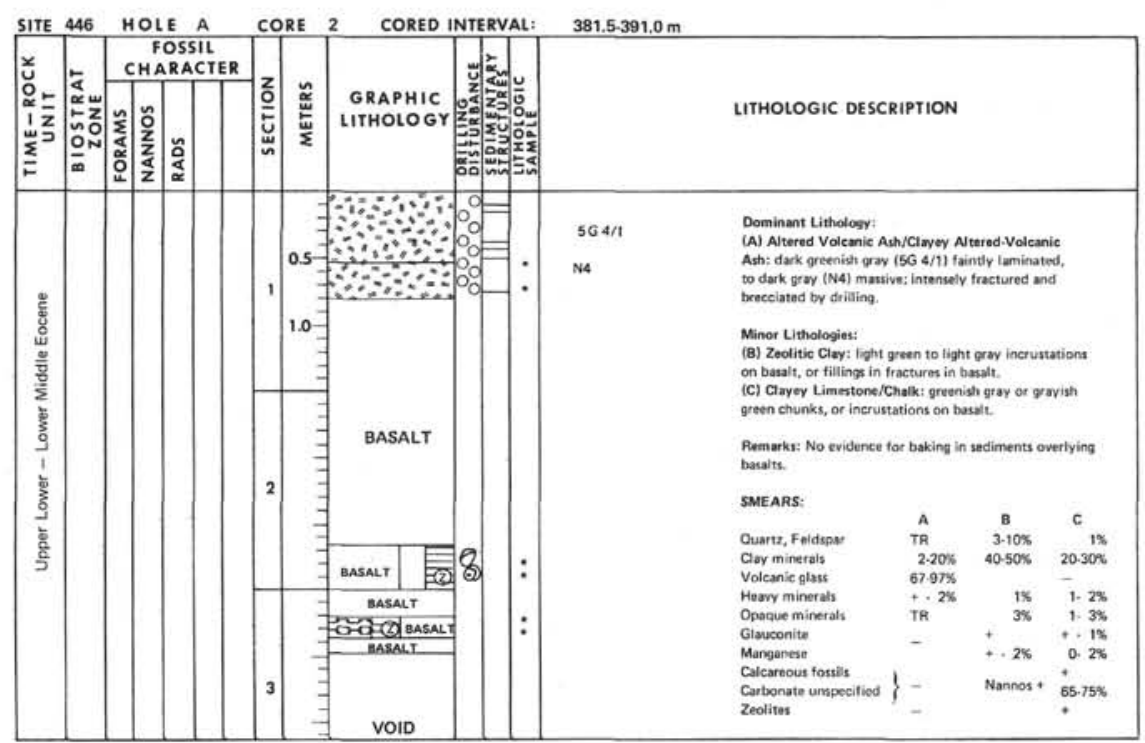




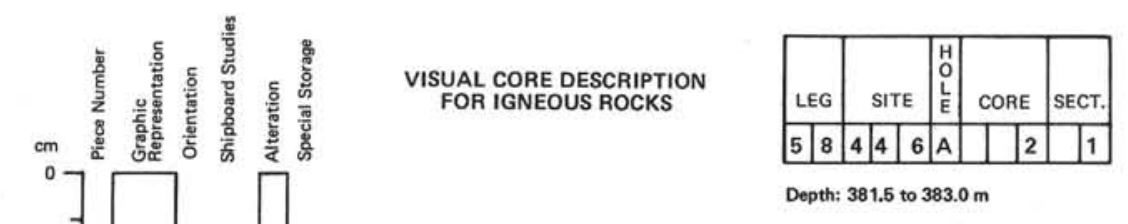

\section{Visual Description
$0.8 \mathrm{~cm}$ : altered ash (sediment).}

. $10 \mathrm{~mm}$.

Piece 1, 80-87 cm: shows glassy margin and chill zone (about $1 \mathrm{~cm}$ thick).

Piece 7 (122.127 partially covered by carbonate-clay vein material; a dso on one side of

Shipboard Data

Magnetic Data:

Intensity (emu/col

$145 \mathrm{~cm}$

Inclination before
demag.

Stable Inclination

Physical Propertic:

$V_{p}(\mathrm{~km} / \mathrm{s})$

Wet Bulk Density

Grain Density

-35.6
-25.7

$145 \mathrm{~cm}$

4.46
13.40

13.40
2.70
2.96

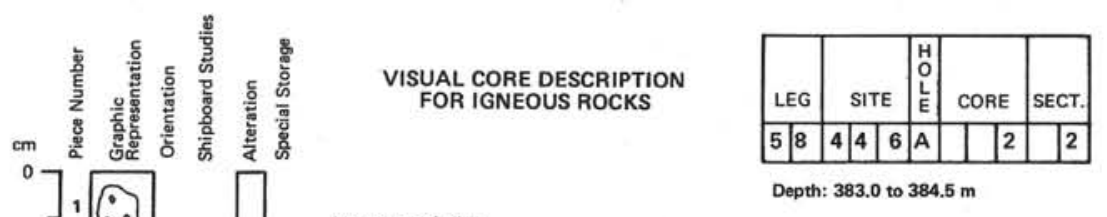

Visual Description

Vester. aphyric, fine-grained vesicular basalt, similar to last section.

作,

White, fine laths of plagioclase are visible in hand specimen and under binocular microscope

Piece $5,111.116 \mathrm{~cm}$ : chill zone and glassy margin.

Pres Odd plagioclase phenocryst. Some carbonate veins. 


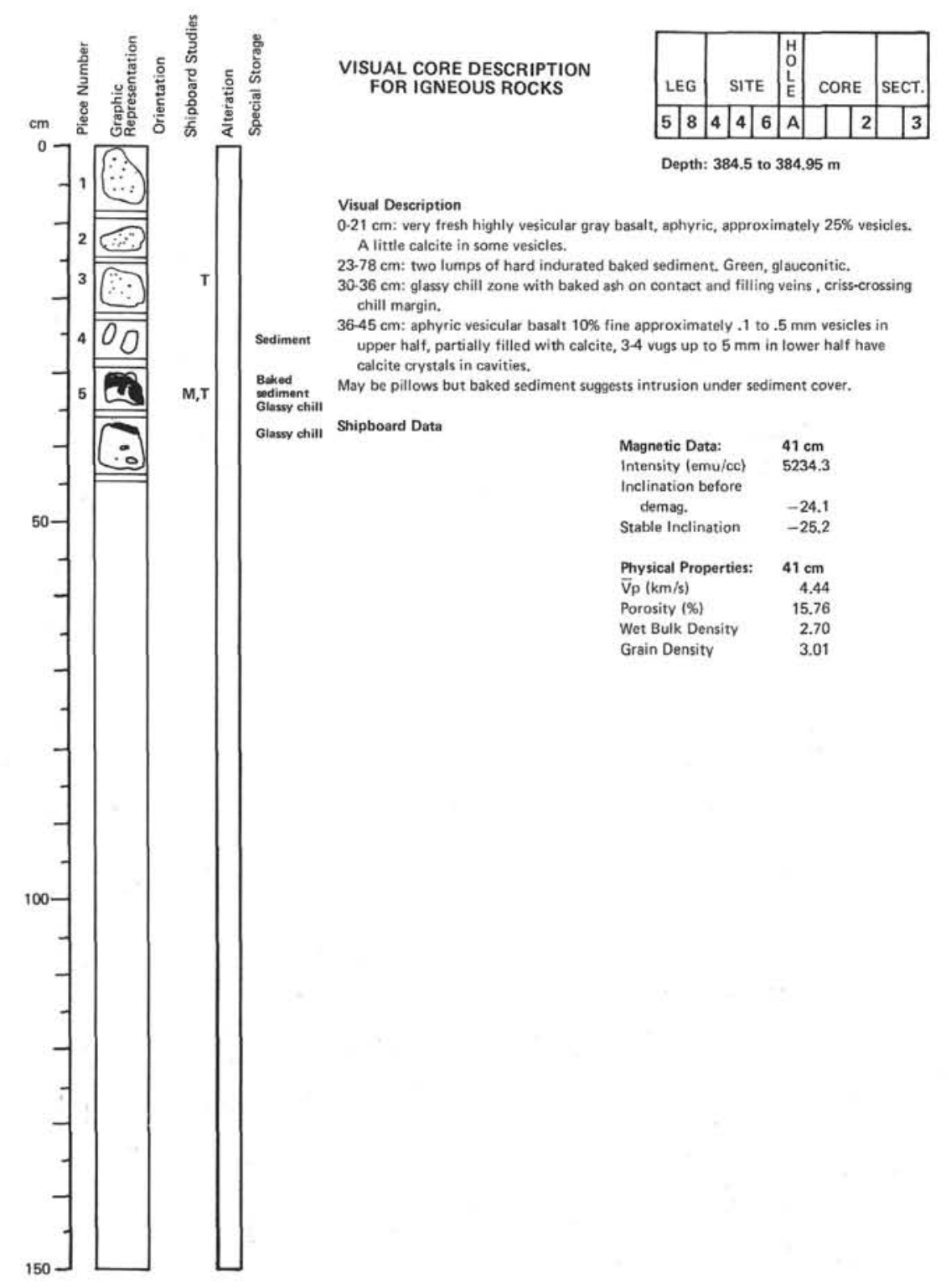




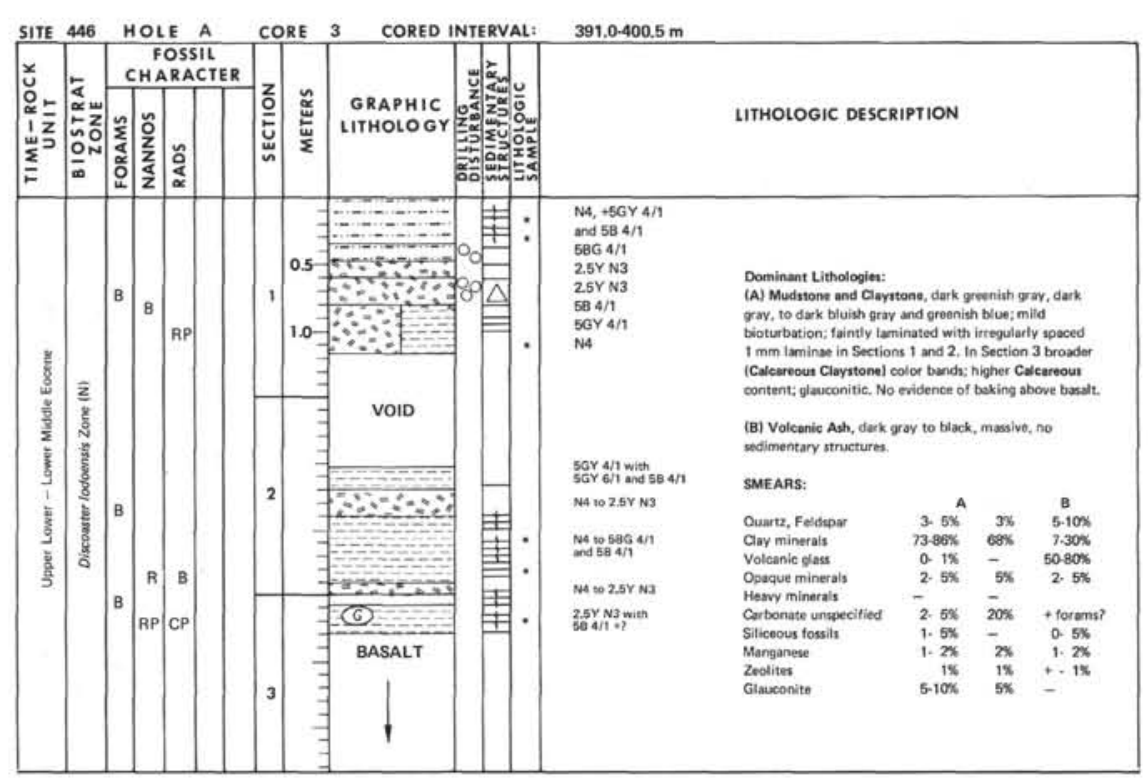



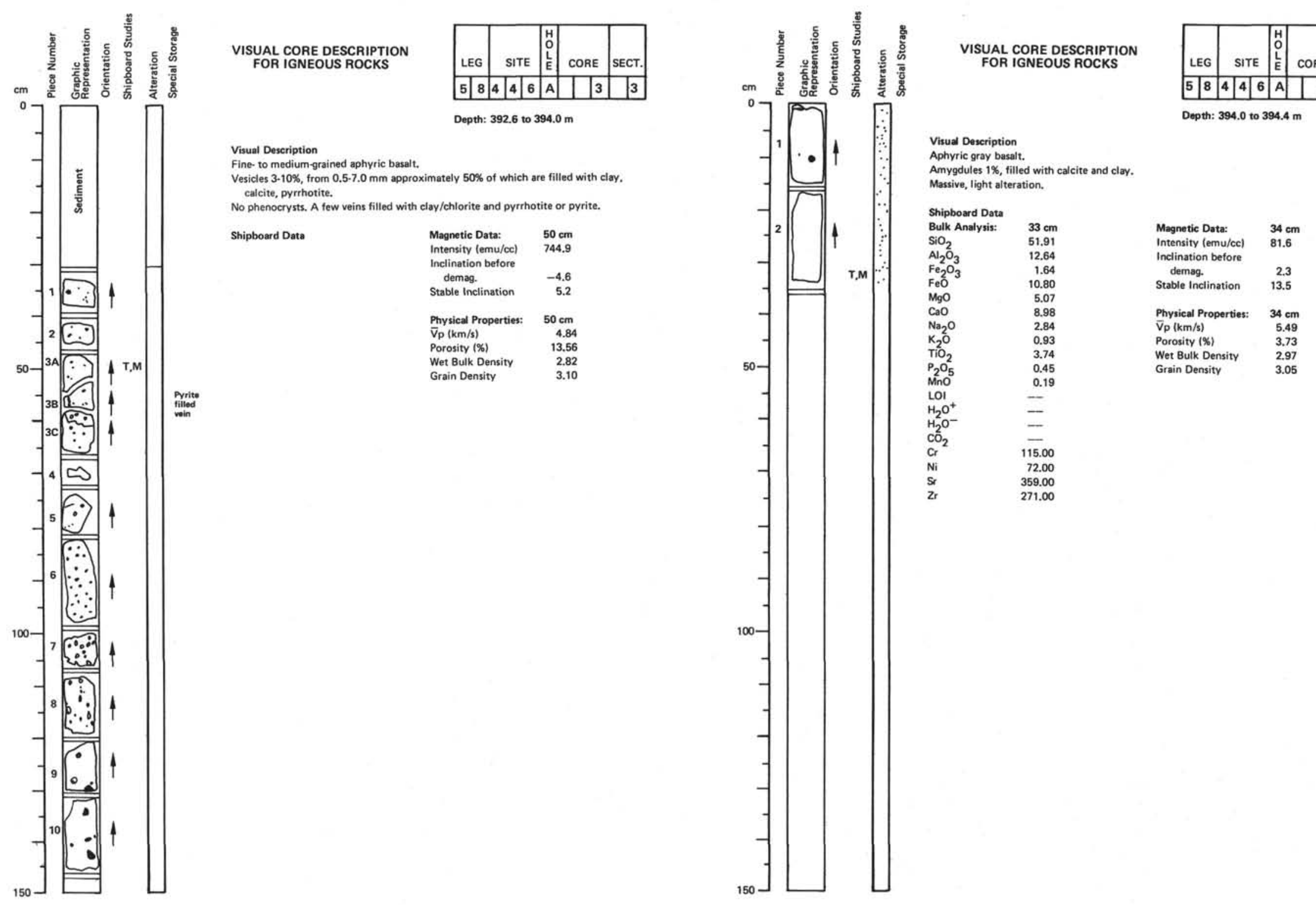

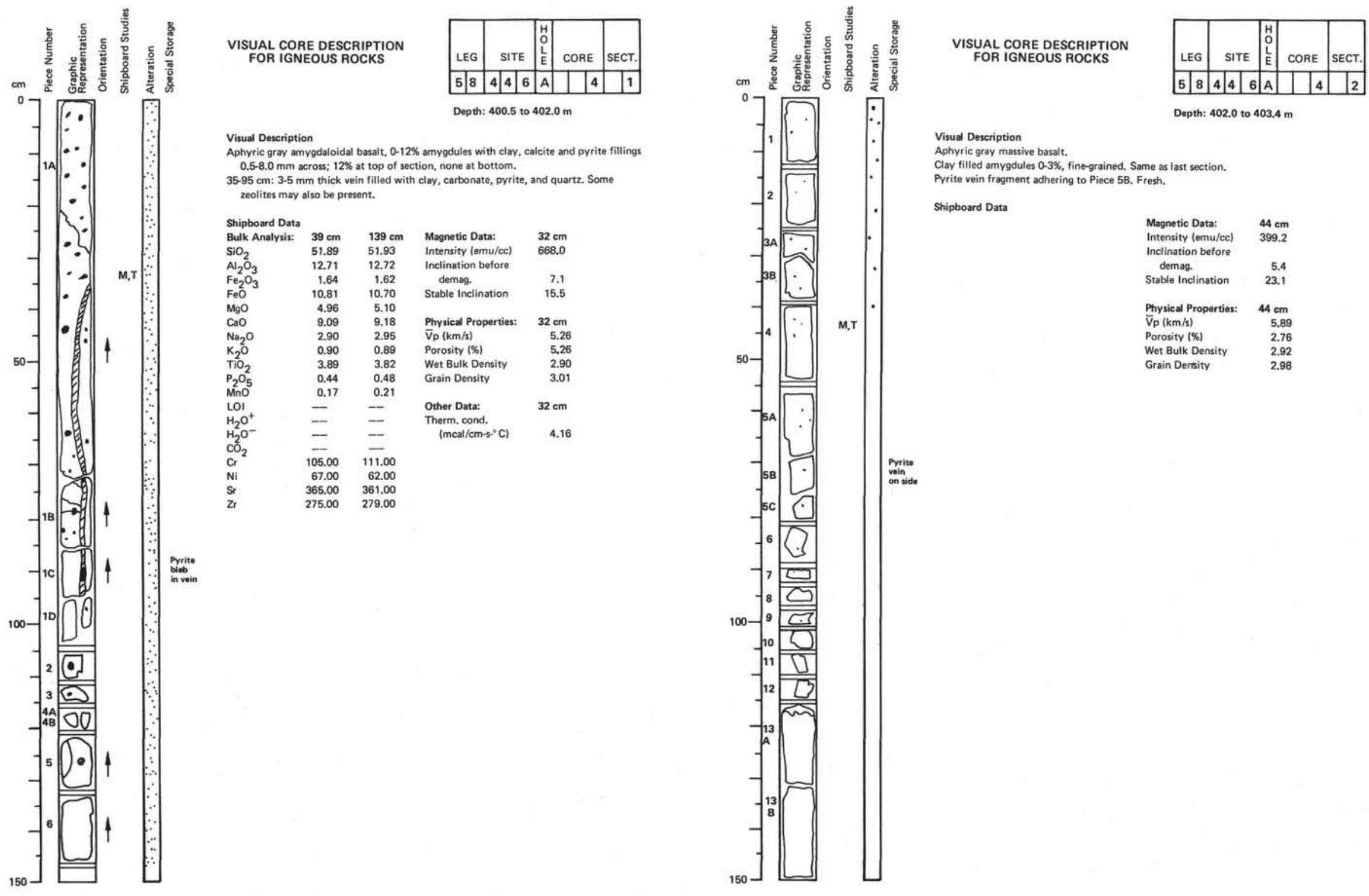

Visual Description

lay filled amygdules 0-3\%, fine-grained. Same as last section. Arrite vein fragment adhering to Piece 58. Fresh.

Shipboard Data

Magnetic Data: Intensity (emu/cc) $\quad 399.2$ $\begin{array}{rr}\text { demag. } & 5.4 \\ \text { Stable Inclination } & 23.1\end{array}$ Physical Properties: $\quad 44 \mathrm{~cm}$
$\mathrm{~V}_{\mathrm{p}}(\mathrm{km} / \mathrm{s})$ Porosity $(\%)$ Wet Bulk Density Grain Density $44 \mathrm{~cm}$
5.89
2.76
2.92

(n) 

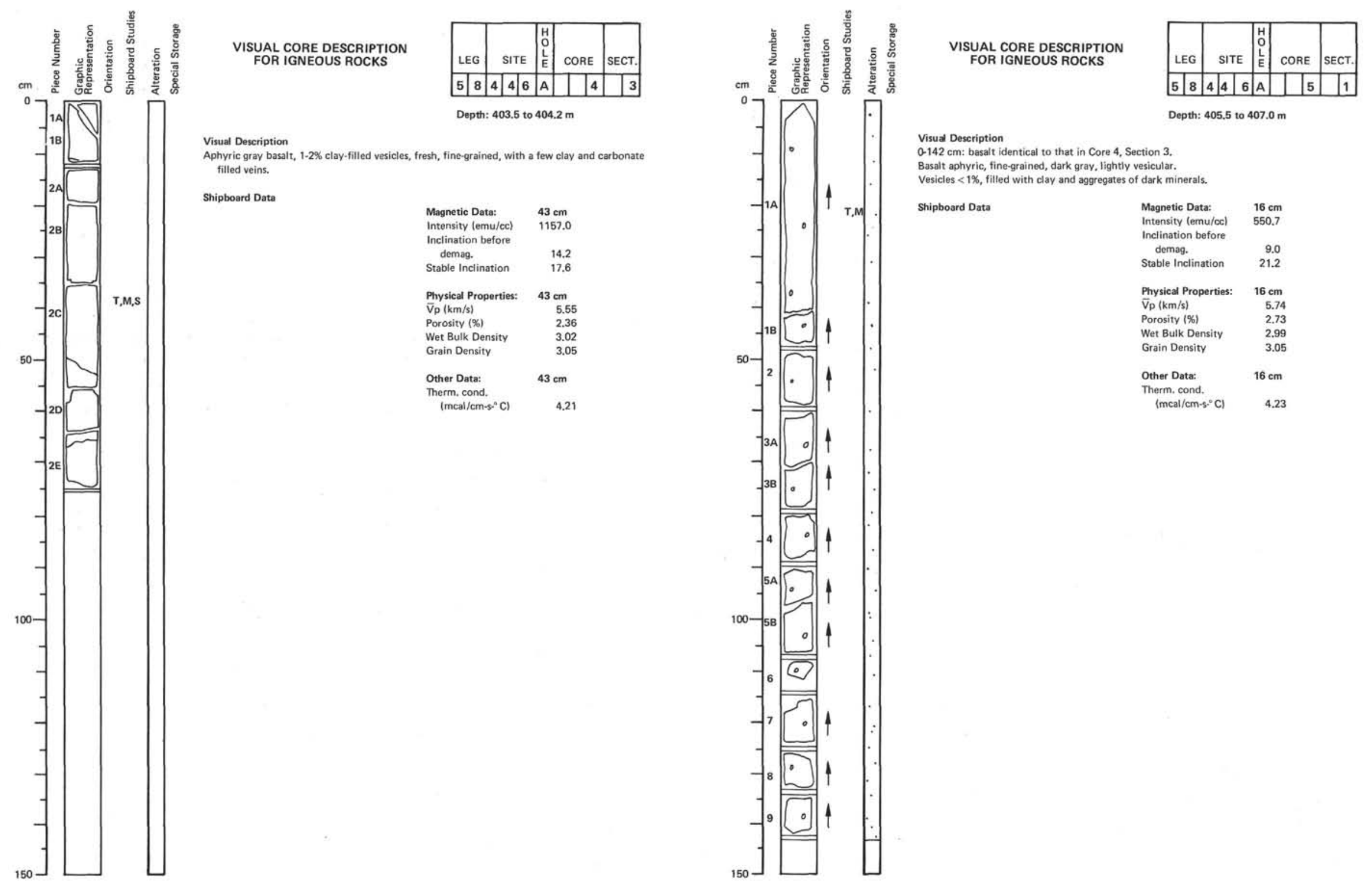

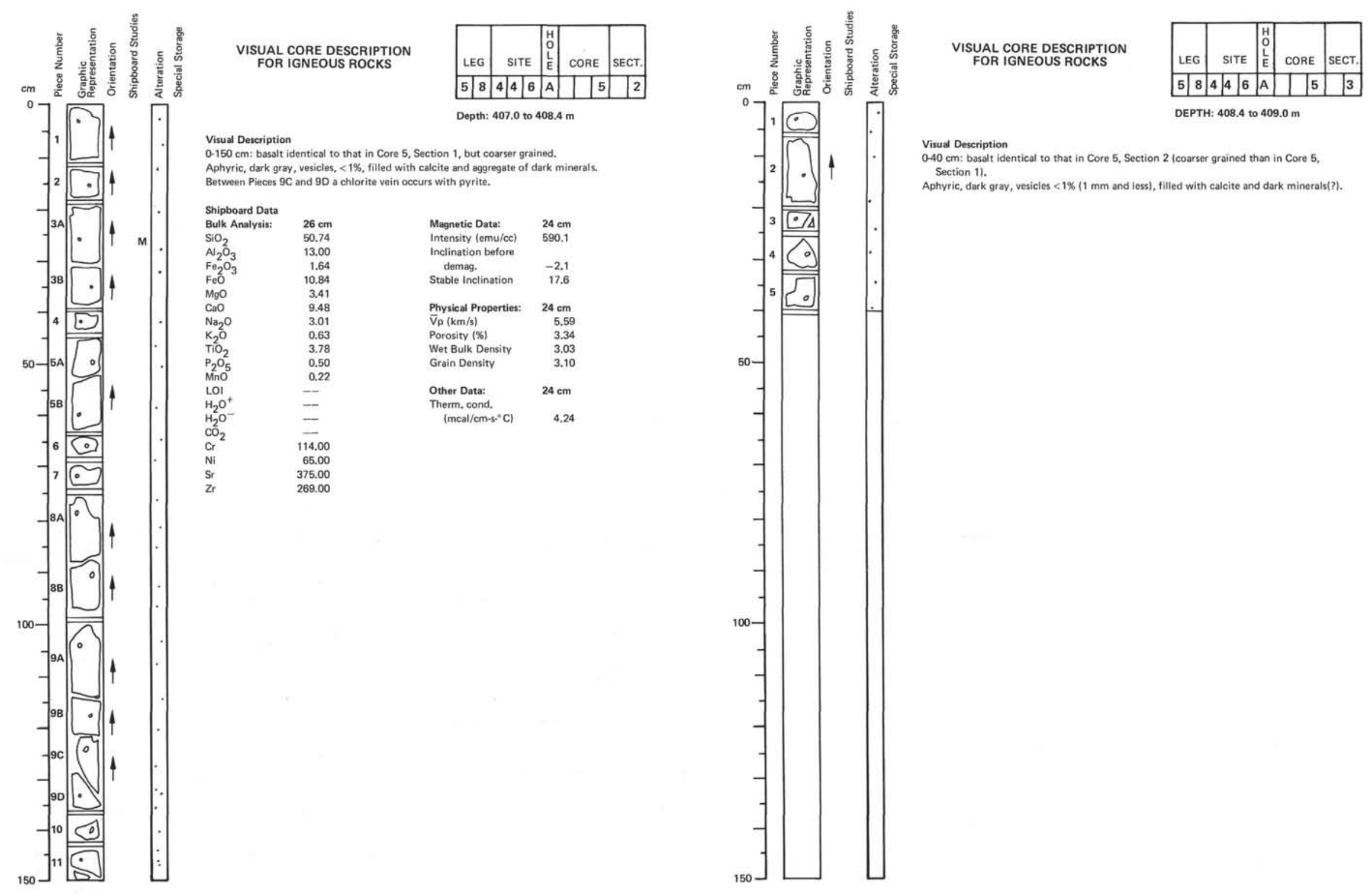

Visual Description

$040 \mathrm{~cm}$ : basalt identical to that in Core 5 , Section 2 lcourser grained than in Core 5 ,

Section 1$)$.
Aphyric, dark gray, vesicles $<1 \%(1 \mathrm{~mm}$ and iess), filled with calcite and dark minerals(?). 


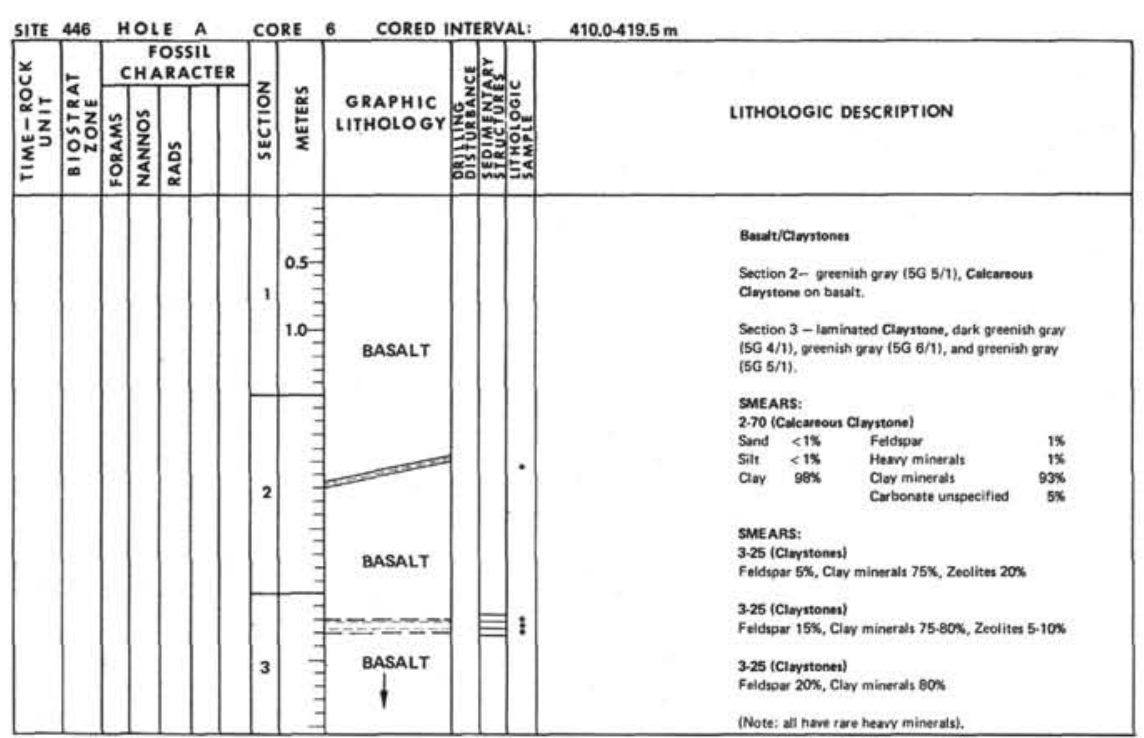




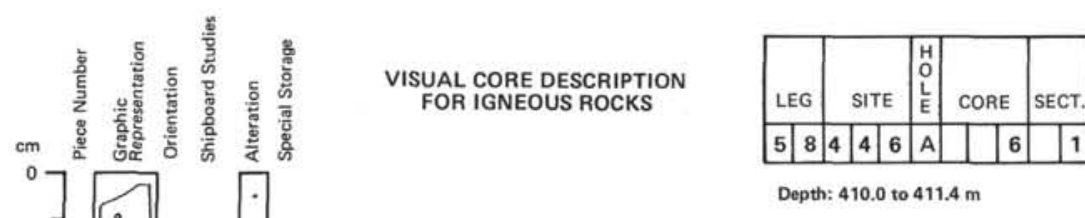

Visual Description 0.142 . $0.142 \mathrm{~cm}$ : basalt,
and chlorite(?). . Shipboard Data

\begin{tabular}{|c|c|}
\hline $\begin{array}{l}\text { Magnetic Data: } \\
\text { Intensity (emu/cc) }\end{array}$ & $\begin{array}{l}10 \mathrm{~cm} \\
474.4\end{array}$ \\
\hline $\begin{array}{l}\text { Inclination before } \\
\text { demag. }\end{array}$ & $4 / 4,4$ \\
\hline Stable Inclination & 3.6 \\
\hline Phys & $10 \mathrm{~cm}$ \\
\hline$\overline{\mathrm{v}}_{\mathrm{pl}}$ & \\
\hline & \\
\hline Wet $B$ & \\
\hline Grain Density & \\
\hline $\begin{array}{l}\text { Other D } \\
\text { Therm. }\end{array}$ & \\
\hline
\end{tabular}

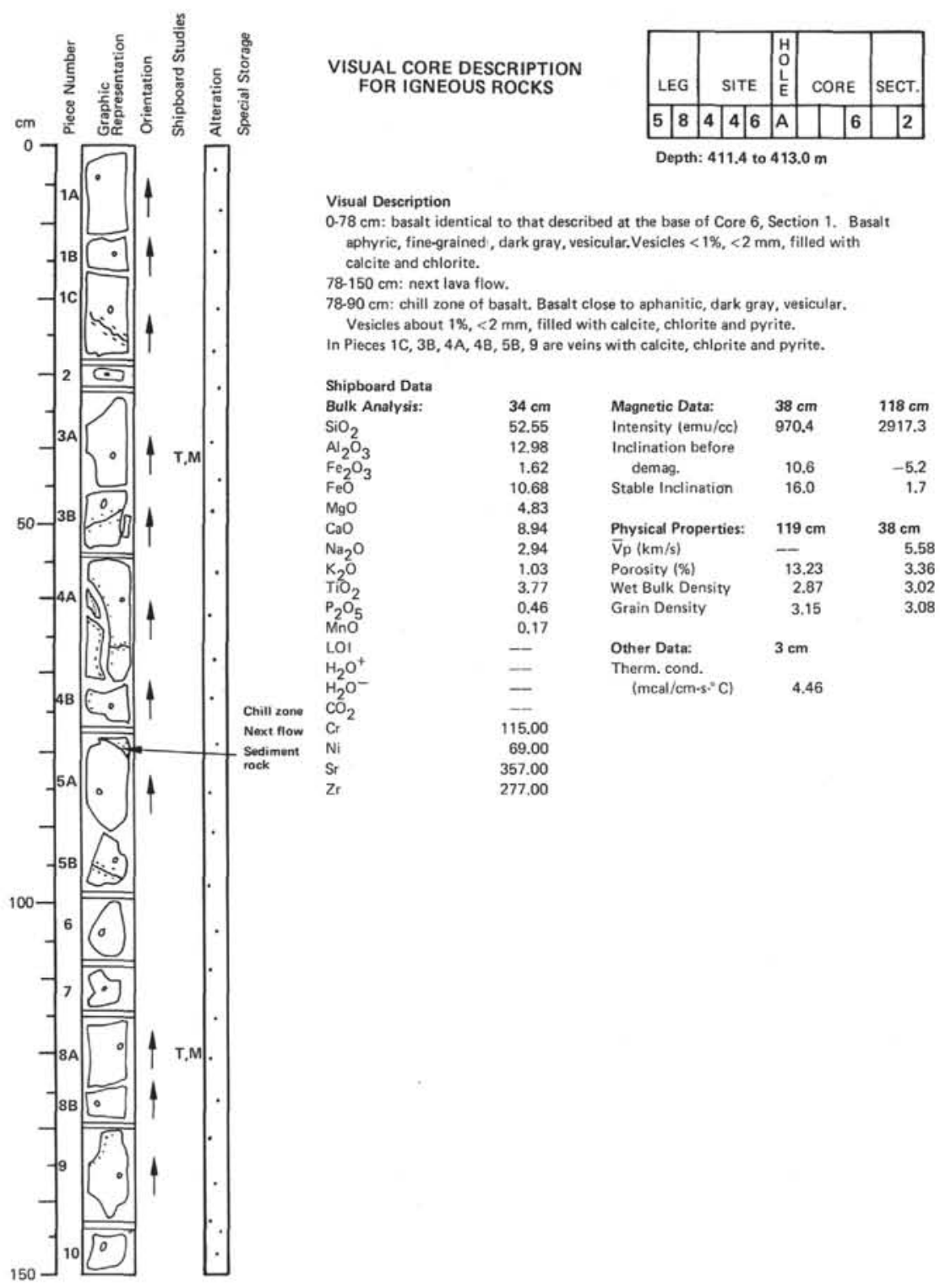



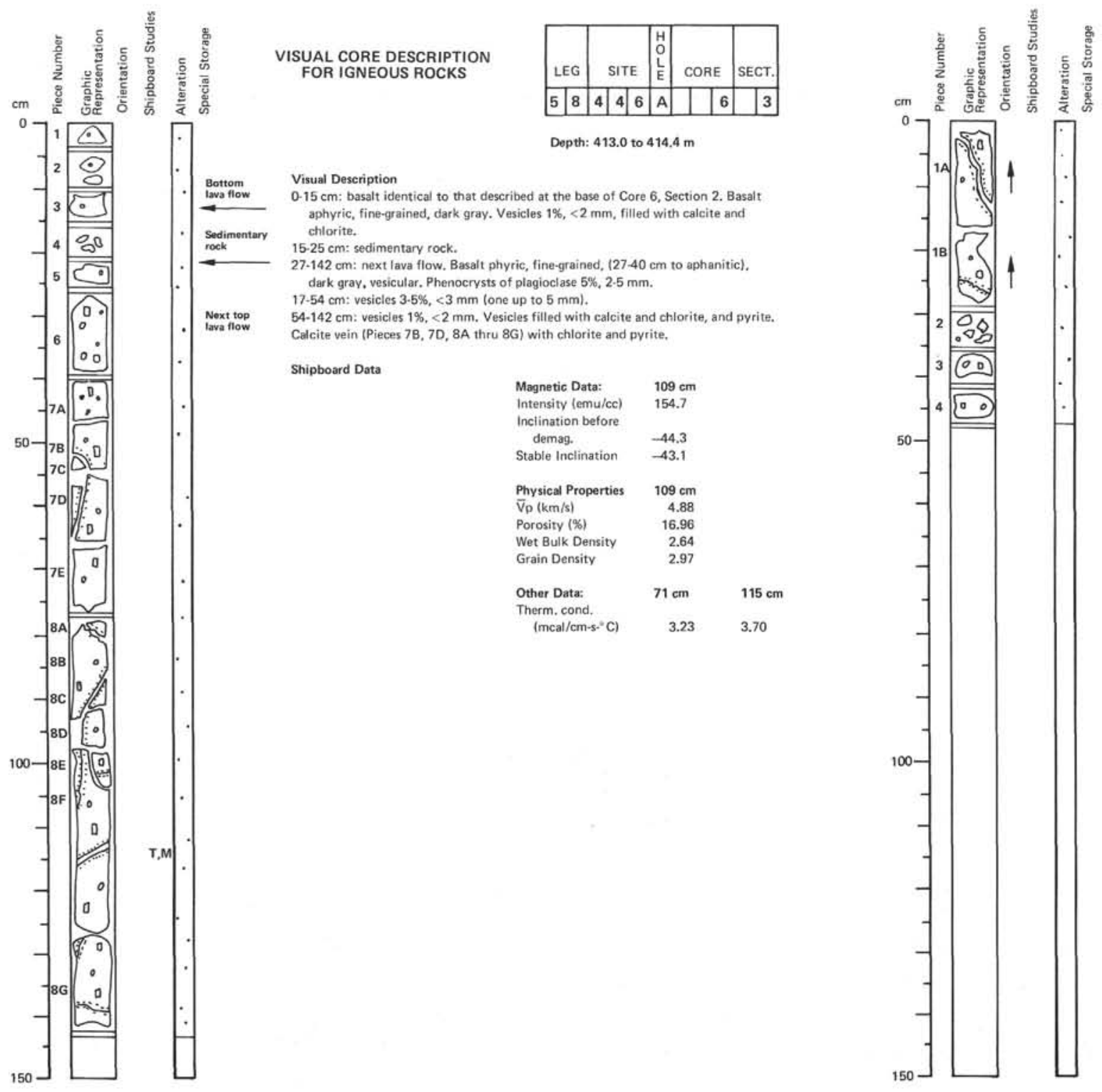

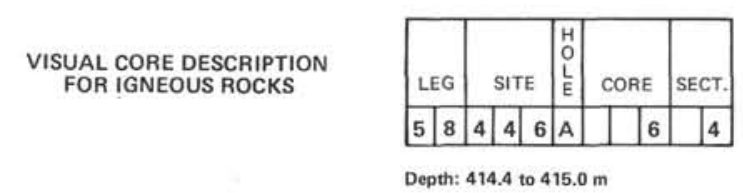

Visual Description

$0.47 \mathrm{~cm}$ : basalt identical to that described for Core 6 , Section 3 . Basalt phyric, fine-grained,
dark gratay, vesicular, Plagioclase phenocrysts $5 \%, 2 \mathrm{~mm}$. Vesicles $<1 \%$, filled with chlorite. 

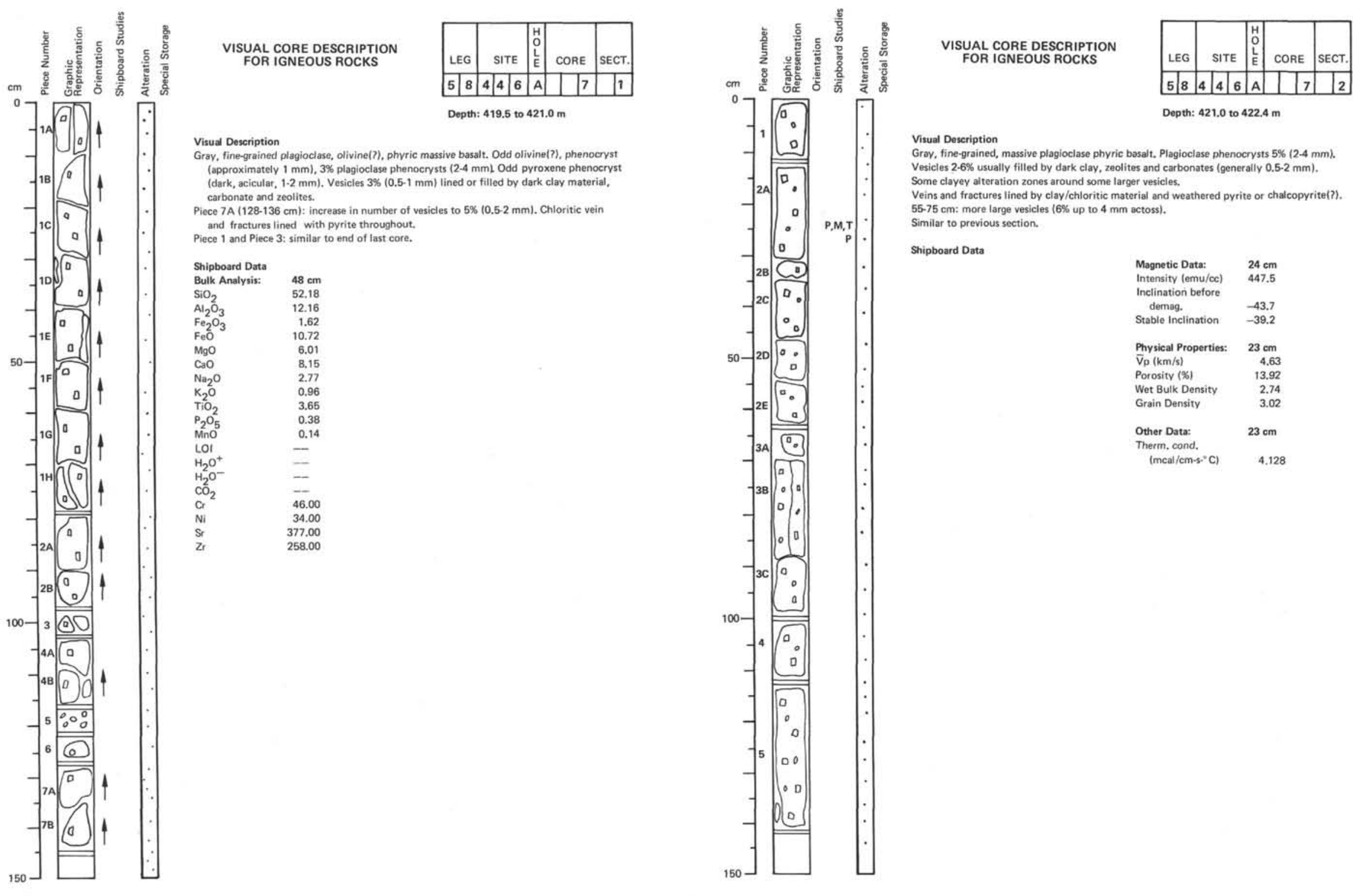


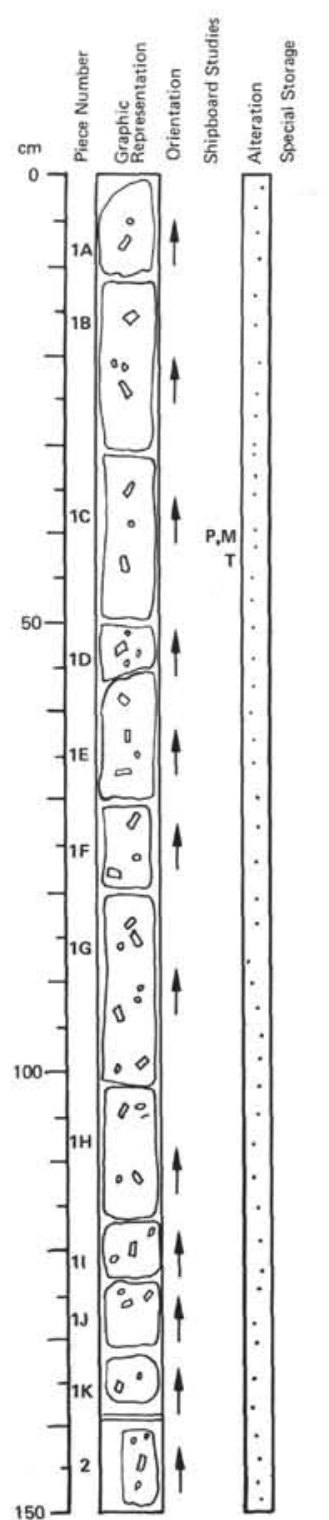

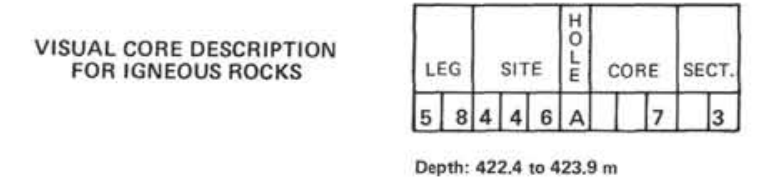

Visual Description

grained, massive, plagioclase phyric basalt. Plagioclase phenocrysts $5 \%(2-4 \mathrm{~mm})$. Vesicles $2-6 \%(0.5-2 \mathrm{~mm})$, lined by dark clay, carbonate and zeolites. Similar to previous section.

Shipboard Data
Bulk Analysis:

$\begin{array}{ll}\text { Bulk Analysis: } & 97 \mathrm{~cm} \\ \mathrm{Si}_{2} \mathrm{O}_{2} & 52.08 \\ \mathrm{Al}_{2} \mathrm{O}_{3} & 12.58 \\ \mathrm{Fe}_{2} \mathrm{O}_{3} & 1.54\end{array}$

$\begin{array}{lr}\mathrm{Fe}_{2} \mathrm{O}_{3} & 1.54 \\ \mathrm{FeO} & 10.17\end{array}$

$\begin{array}{ll}\mathrm{MgO} & 5.32 \\ \mathrm{C} 3 \mathrm{O} & 8.98\end{array}$

$\begin{array}{ll}\mathrm{Ca}_{2} \mathrm{O} & 8.98 \\ \mathrm{~K}_{2} \mathrm{O} & 2.86 \\ \mathrm{~T}^{\mathrm{O}} \mathrm{O} & 0.90 \\ \mathrm{P} & 3.80\end{array}$

$\begin{array}{ll}\mathrm{P}_{2} & 3.80 \\ \mathrm{P}_{2} \mathrm{O}_{5} & 0.45 \\ \mathrm{MnO} & 0.15\end{array}$

$\begin{array}{ll}\mathrm{LOI}_{2} & = \\ \mathrm{H}_{2} \mathrm{O}^{+} & = \\ \mathrm{H}_{2} \mathrm{O}^{-} & -\end{array}$

$\begin{array}{lr}\mathrm{c}^{2} & 54.00 \\ \mathrm{Ni} & 41.00 \\ \mathrm{Si} & 398.00 \\ \mathrm{Zr} & 270.00\end{array}$ Inclination before \begin{tabular}{ll} 
Stable Inclination & -39.5 \\
\hline & -45.3
\end{tabular} $V_{p}(\mathrm{~km} / \mathrm{s})$
Porosity (\%) Other Data: $38 \mathrm{~cm}$ (mcal//cm-s." C) 3.81

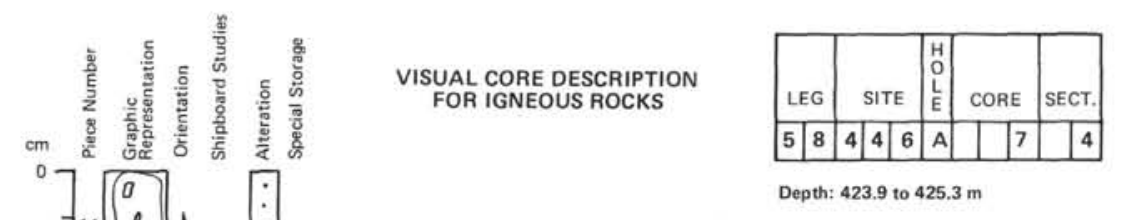

Visual Description

Gray, fine-grained, massive, plagioclase phyric basalt. Plagioclase phenocrysts $5 \%(2.4 \mathrm{~mm})$

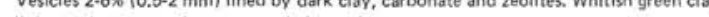

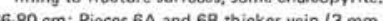
ss) filled by zeolite(?). Large cluster of chalcopyrite on Piece $1 A(5-6 \mathrm{~cm})$. us section. $38 \mathrm{~cm}$ Physical Properties: $\quad 38 \mathrm{~cm}$ Wet Bulk Density $\quad 15.49$ Grain Density $\quad 3.13$

\begin{tabular}{|c|c|c|}
\hline ggnetic Data: & $138 \mathrm{~cm}$ & \\
\hline Intensity (emu/ce) & 833.8 & \\
\hline demag. & -48.8 & \\
\hline Stable Inclination & -49.1 & \\
\hline Physical Properties: & $75 \mathrm{~cm}$ & $138 \mathrm{~cm}$ \\
\hline$\overline{\mathrm{V}}_{p}(\mathrm{~km} / \mathrm{s})$ & - & 4.69 \\
\hline Porosity (\%) & 8.77 & \\
\hline Wet Bulk Density & 2.83 & - \\
\hline Grain Density & 3.01 & - \\
\hline $\begin{array}{l}\text { Other Data } \\
\text { Therm, }\end{array}$ & $138 \mathrm{~cm}$ & \\
\hline $\begin{array}{l}\text { Therm, cond. } \\
\text { (mcal/cm.s.". }\end{array}$ & 3.95 & \\
\hline
\end{tabular}

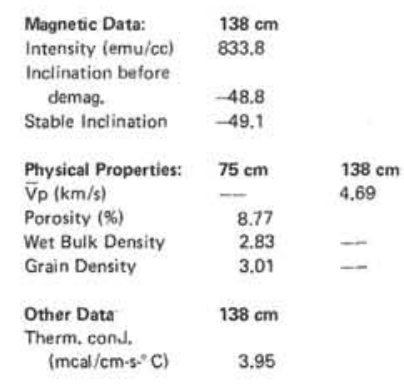



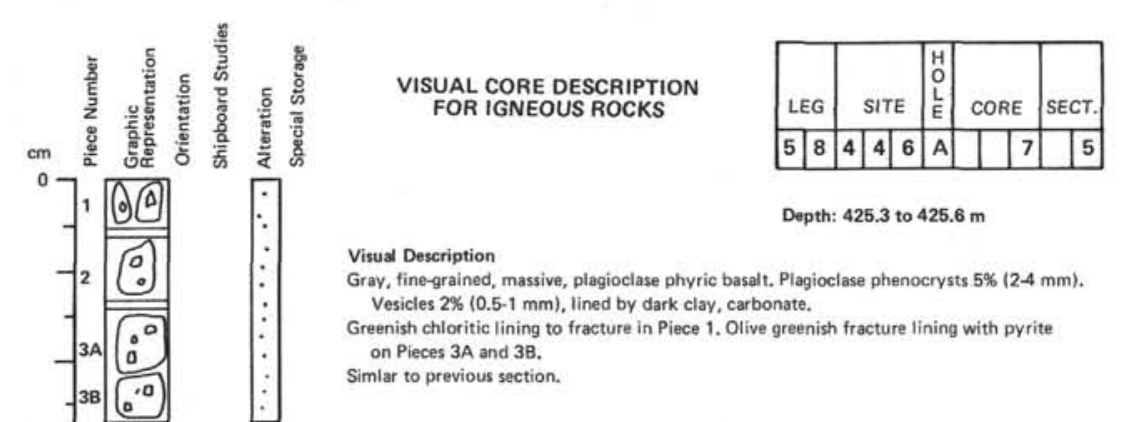

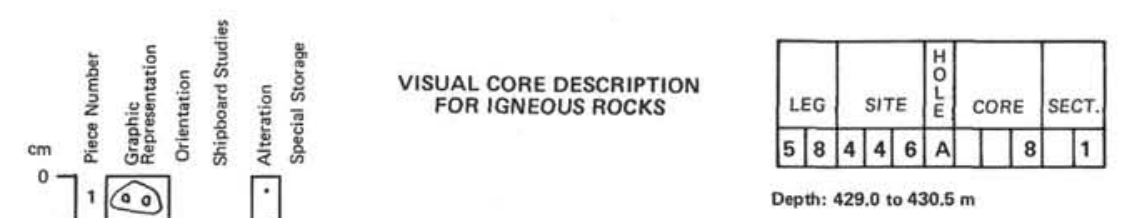

Visual Description

Gray, massive, fine-grained, plagioclase phyric basalt. Plagioclase phenocrysts $5 \%(2-4 \mathrm{~mm})$. Frasides lined by dark brown clay and carbonate. Vesicles $1.5 \%(0.5 \cdot 2 \mathrm{~mm})$.

Occasional larger pyroxene around plagioclase laths observed under binocular microscope. Similar to previous core.

5 are finer grained but may be due to uphole contamination (from top

Shipboard Data $\quad 66 \mathrm{~cm}$

$\mathrm{SiO}_{2}$

$\mathrm{Al}_{2} \mathrm{O}_{3} \quad 12.67$

$\mathrm{FeO}_{2} \quad 1.53$

$\mathrm{MgO}$

$\mathrm{CaO}$

\begin{tabular}{ll}
$\mathrm{CaO}_{2} \mathrm{O}$ & 8.74 \\
$\mathrm{Na}_{2}$ & 3.21 \\
\hline
\end{tabular}

$\mathrm{K}_{2} \mathrm{O} \quad 0.71$

\begin{tabular}{ll}
$\mathrm{TiO}_{2}$ & 3,55 \\
$\mathrm{P}_{2} \mathrm{O}_{5}$ & 0.44 \\
\hline
\end{tabular}

0.15

$\begin{array}{ll}\mathrm{LOI}_{2} \mathrm{O}^{+} & = \\ \mathrm{H}_{2} \mathrm{O}^{-} & =\end{array}$

$\begin{array}{ll}\mathrm{H}_{2} \mathrm{O}^{-} & - \\ \mathrm{CO}_{2} & - \\ \mathrm{Cr}^{2} & \mathbf{8 1 . 0 0}\end{array}$

$\begin{array}{ll}\mathrm{Cr} & 81.00 \\ \mathrm{Ni} & 46.00 \\ \mathrm{Sr} & 38800\end{array}$

$\begin{array}{ll}\text { Sr } & 388.00 \\ \mathrm{Zr} & 258.00\end{array}$

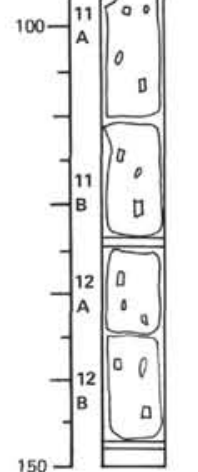

Magnetic Data: Inensity (emu/cc) 820 . demag.
Stable Incl. 20.5 Physical Properties: $\quad 74 \mathrm{~cm}$ $\mathrm{Vp}(\mathrm{km} / \mathrm{s})$ Porosity (m) Wet Bulk Density $\quad 2.74$
Grain Density 


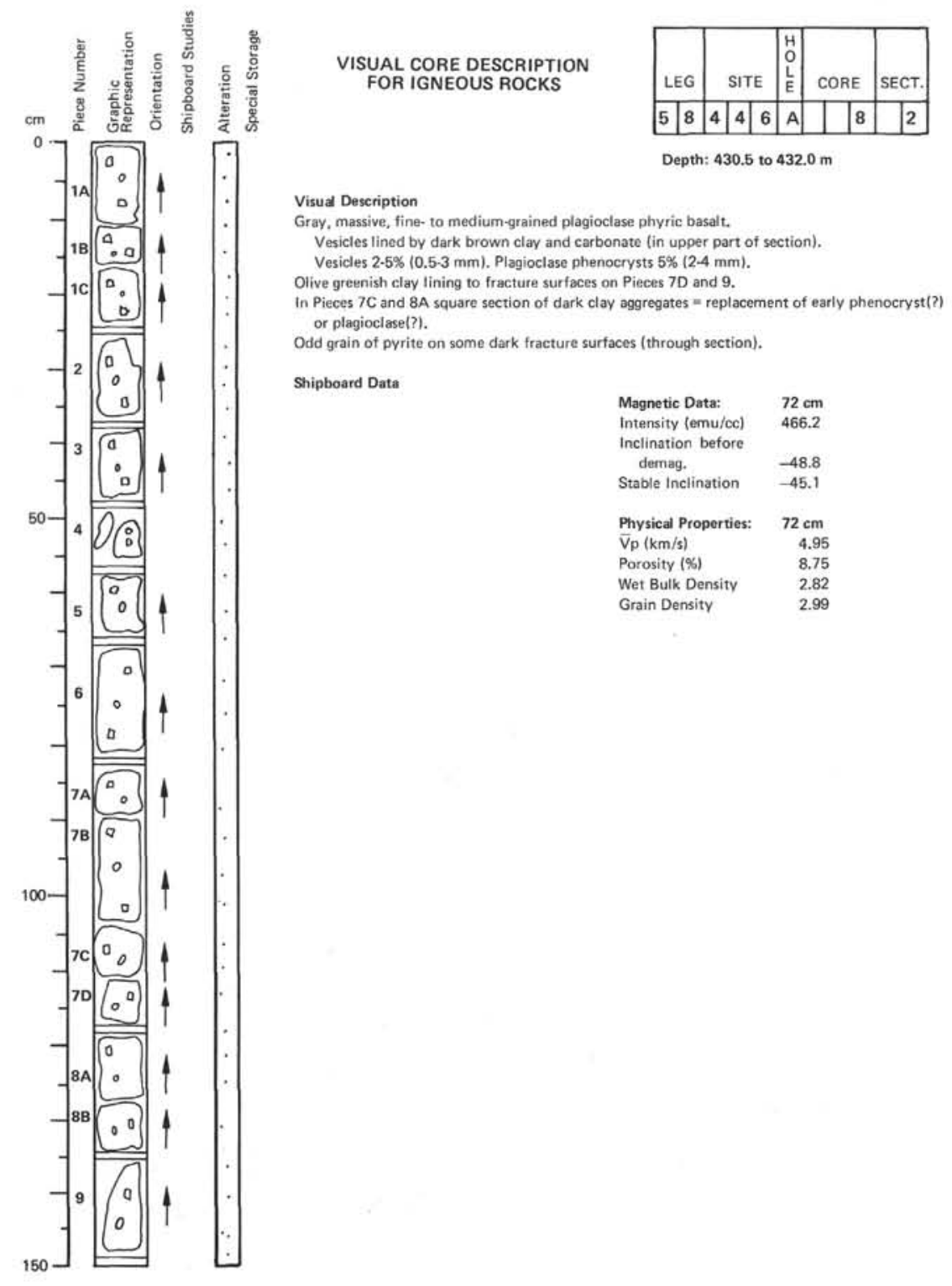




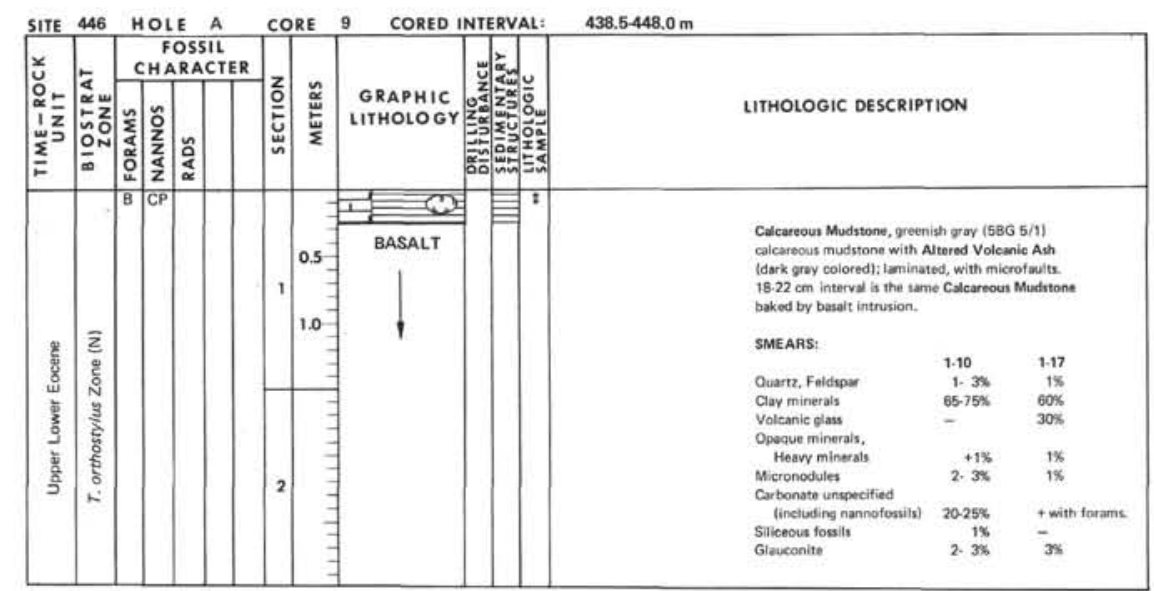



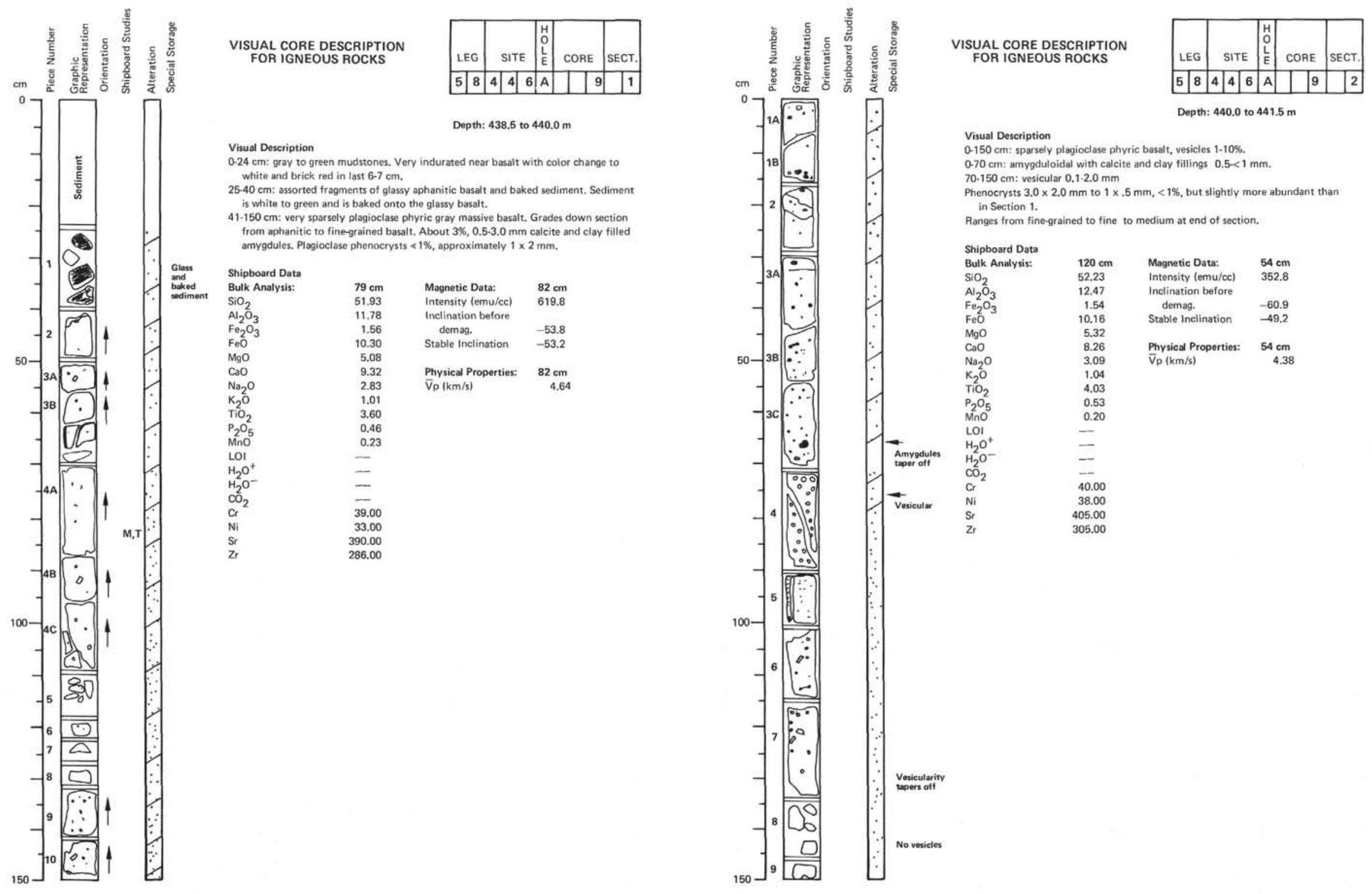


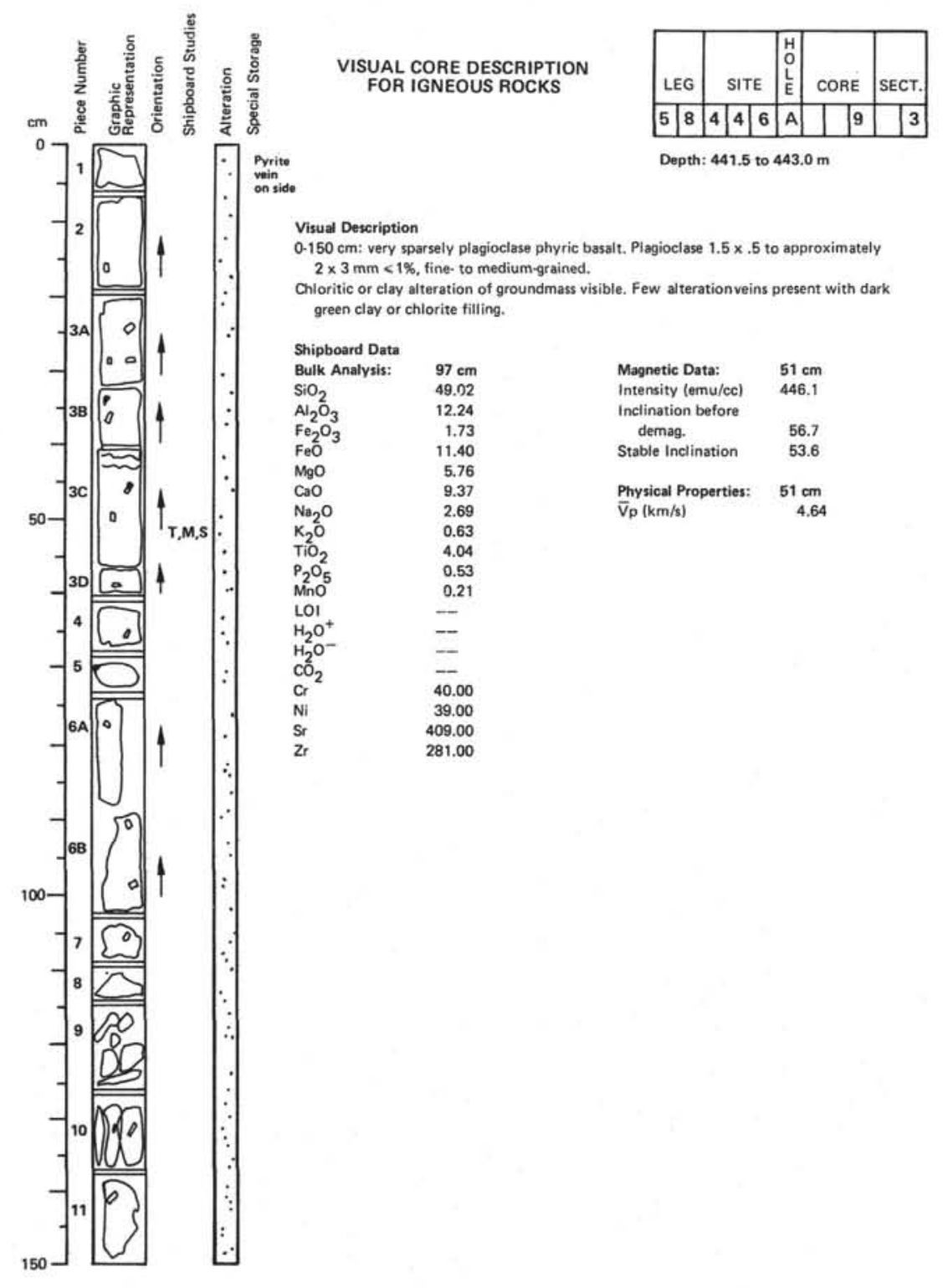


SIIE 446 HOLE A CORE 10 CORED INTERVAL: $448.0457 .5 \mathrm{~m}$

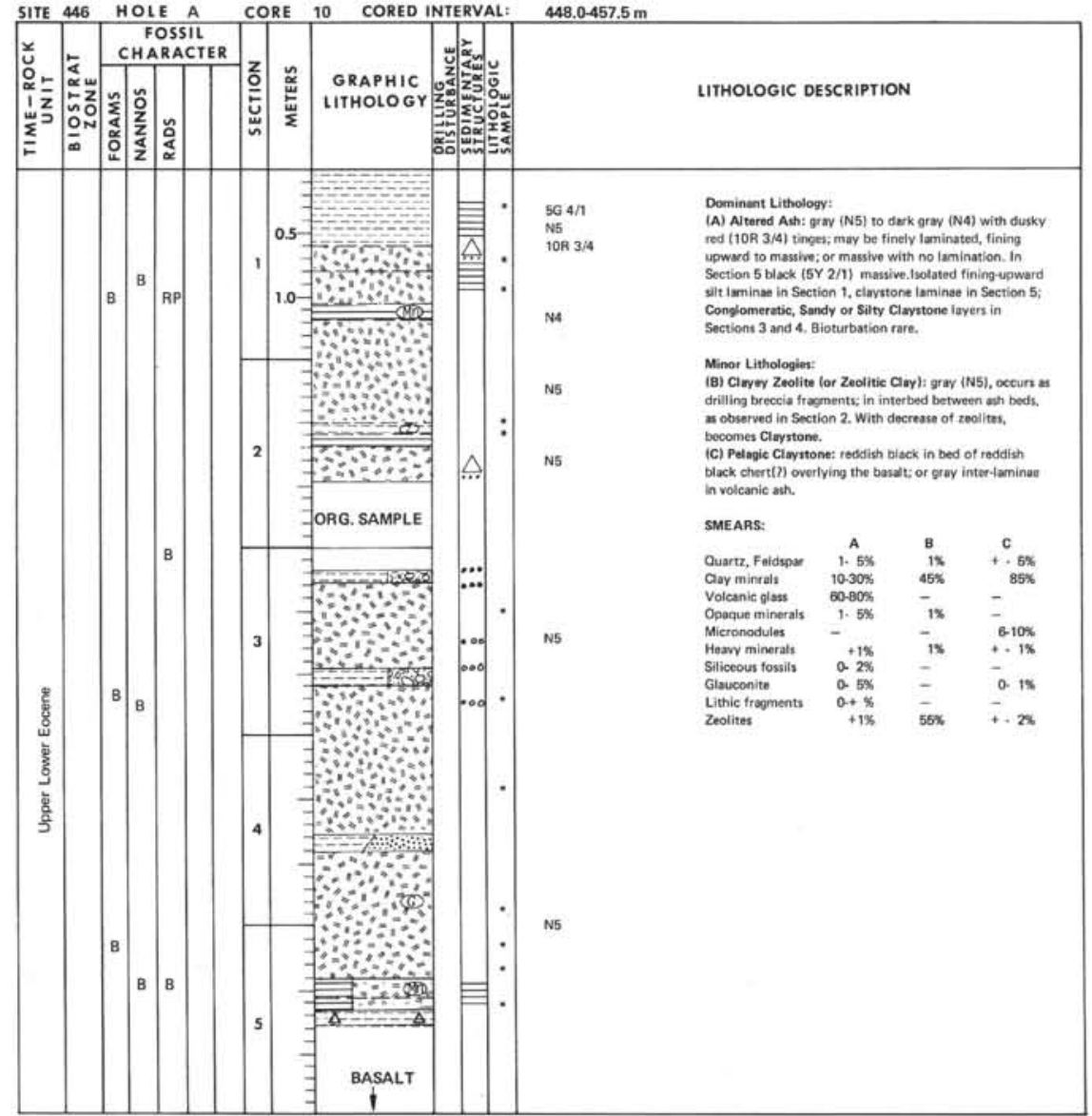



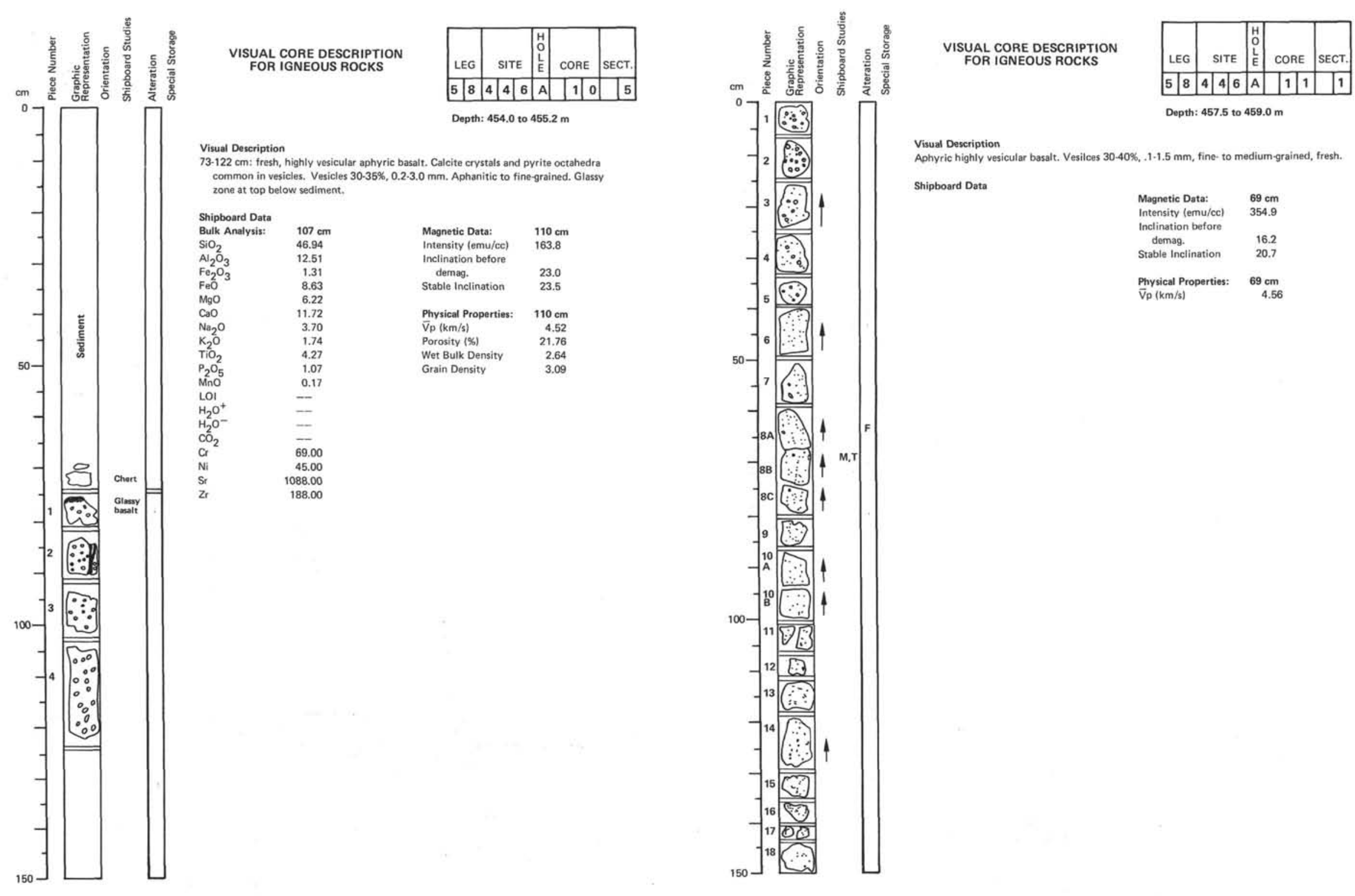

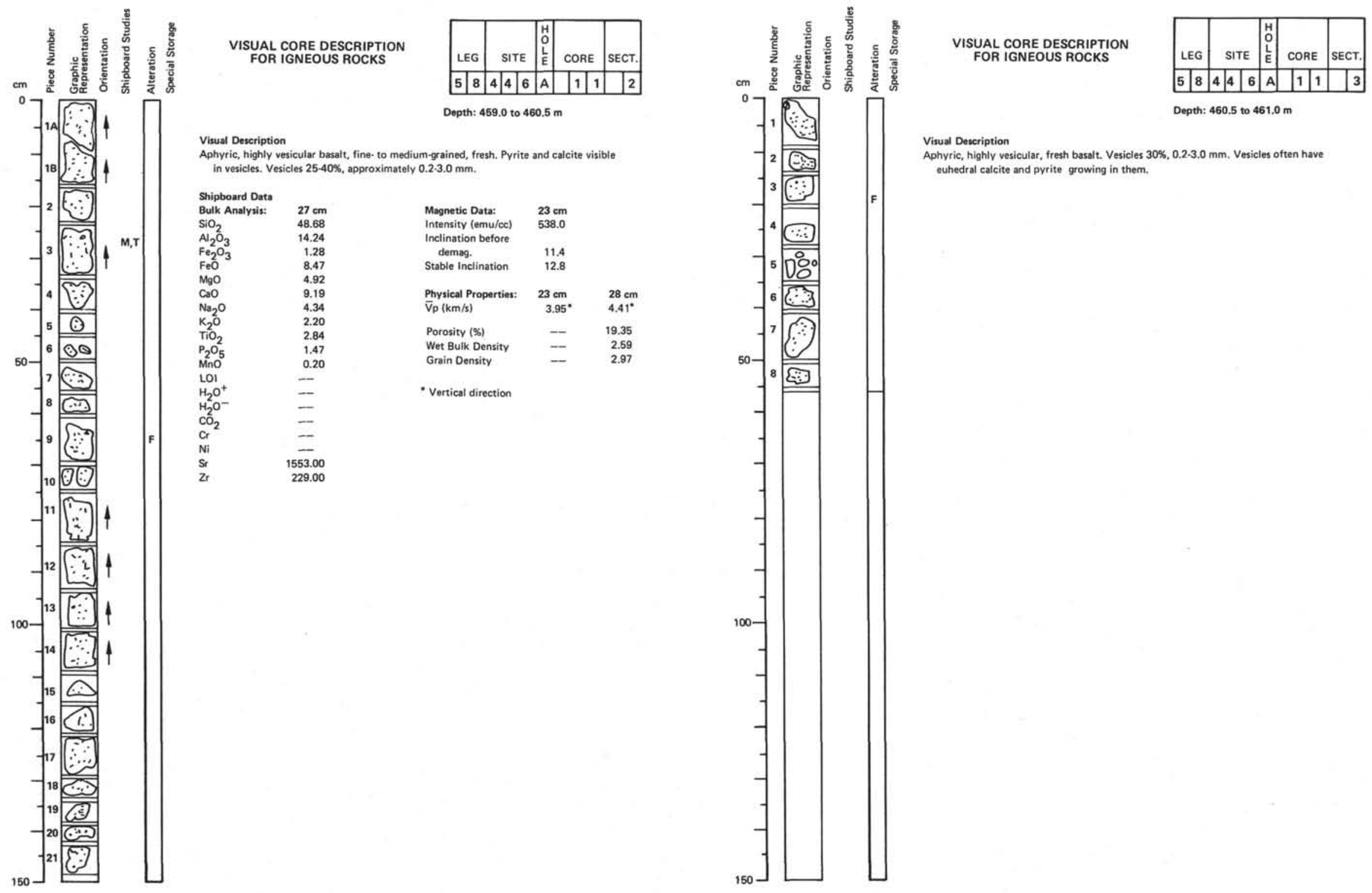

Visual Description

作, euhedral calcite and pyrite growing in them. 


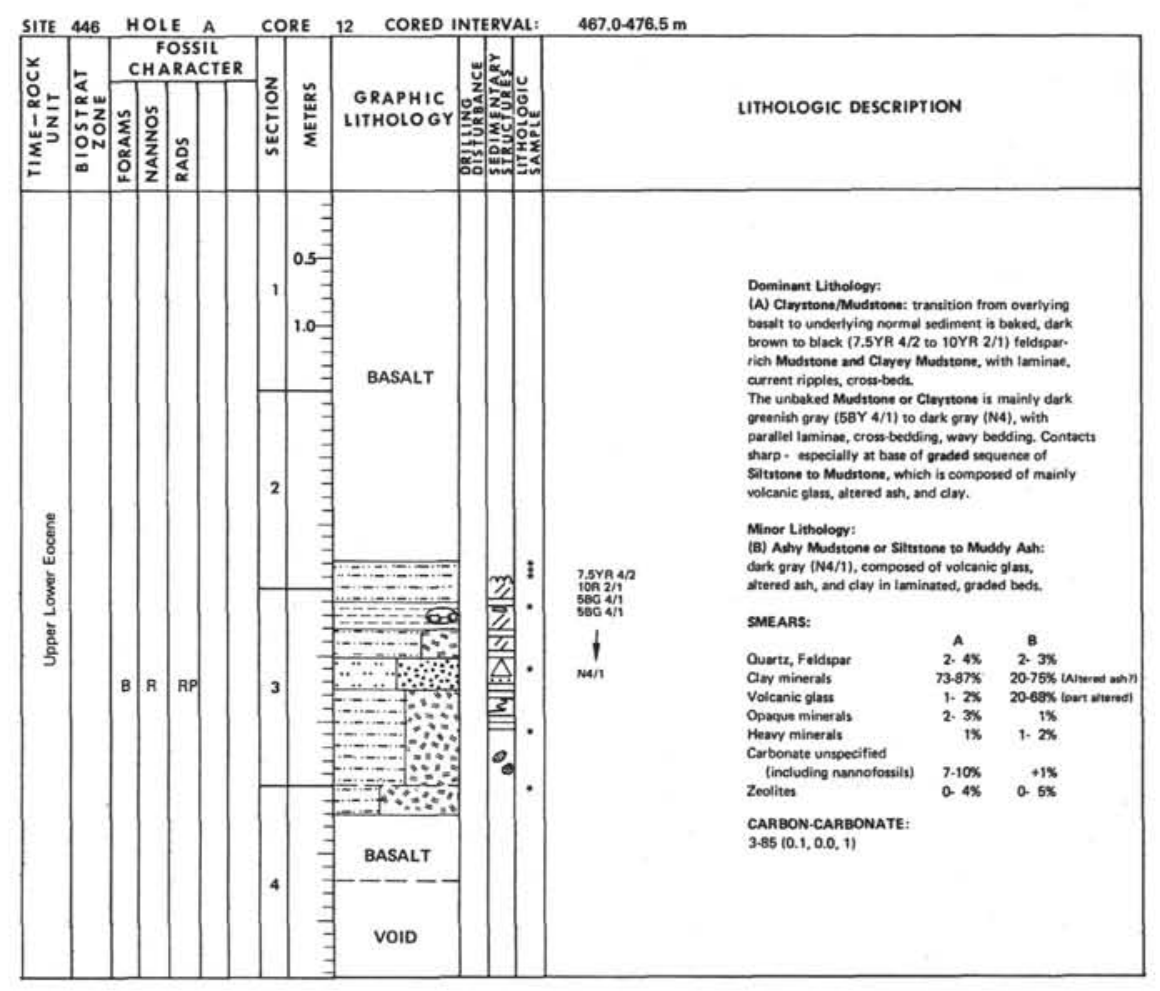



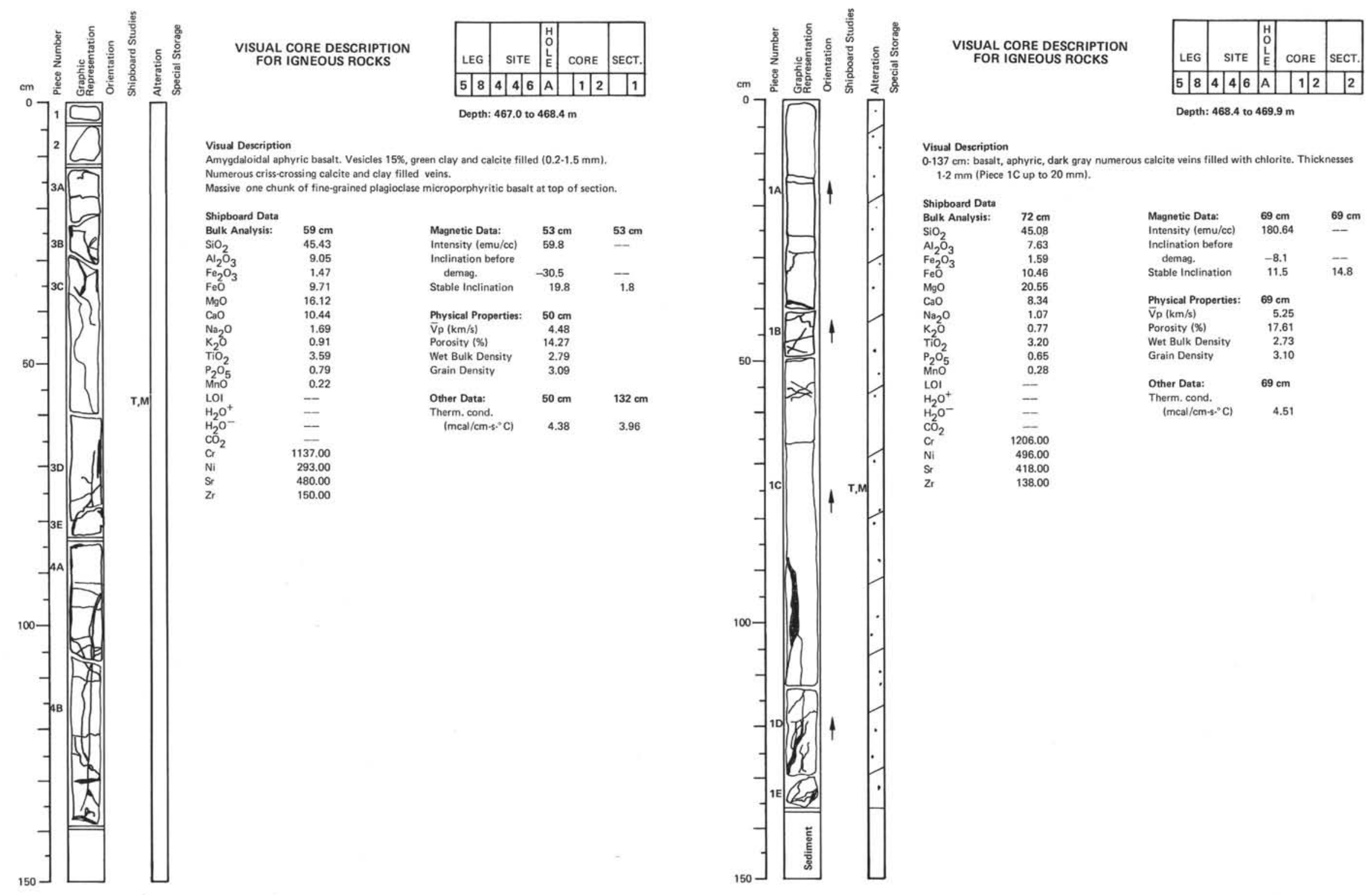

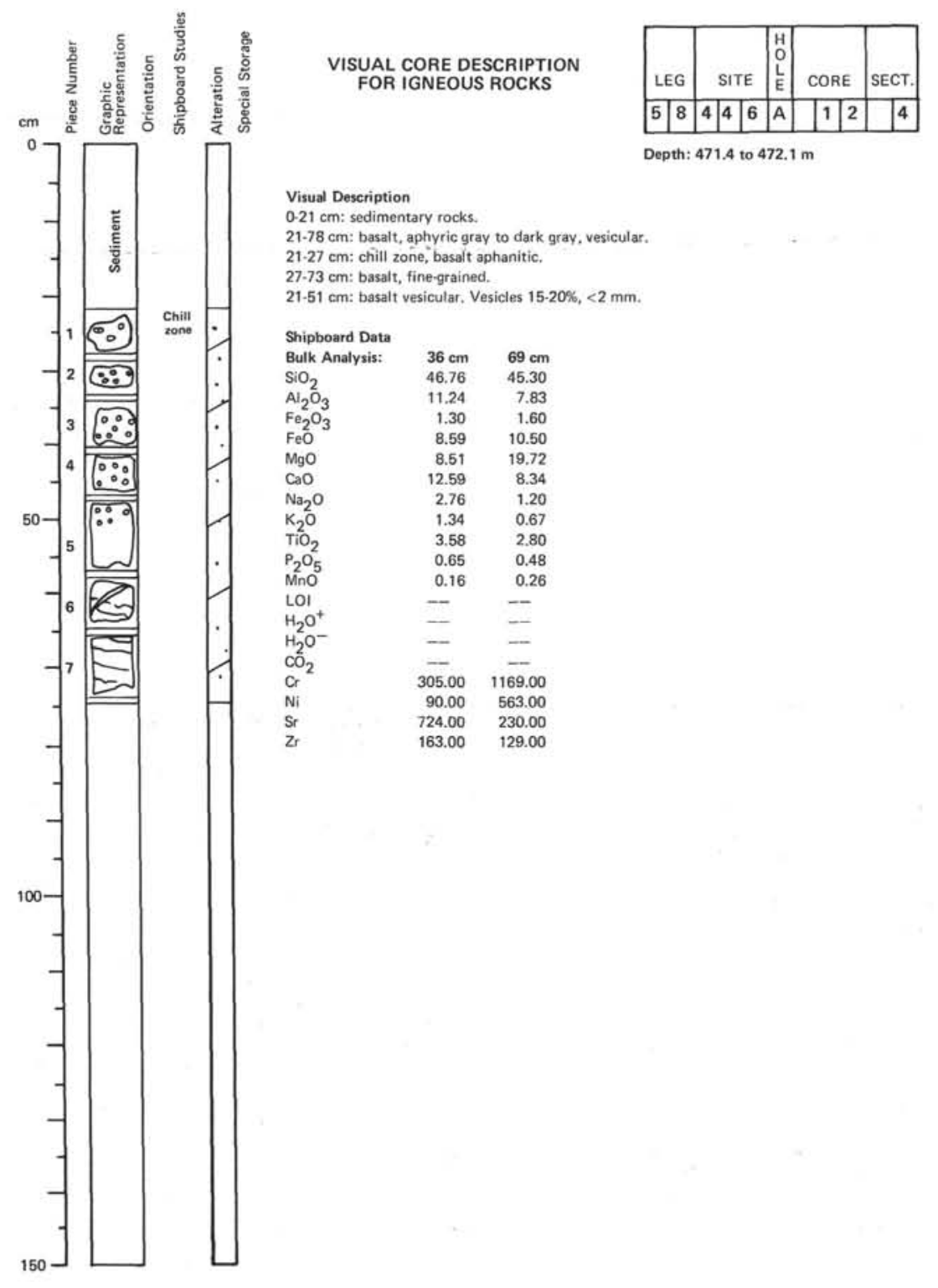


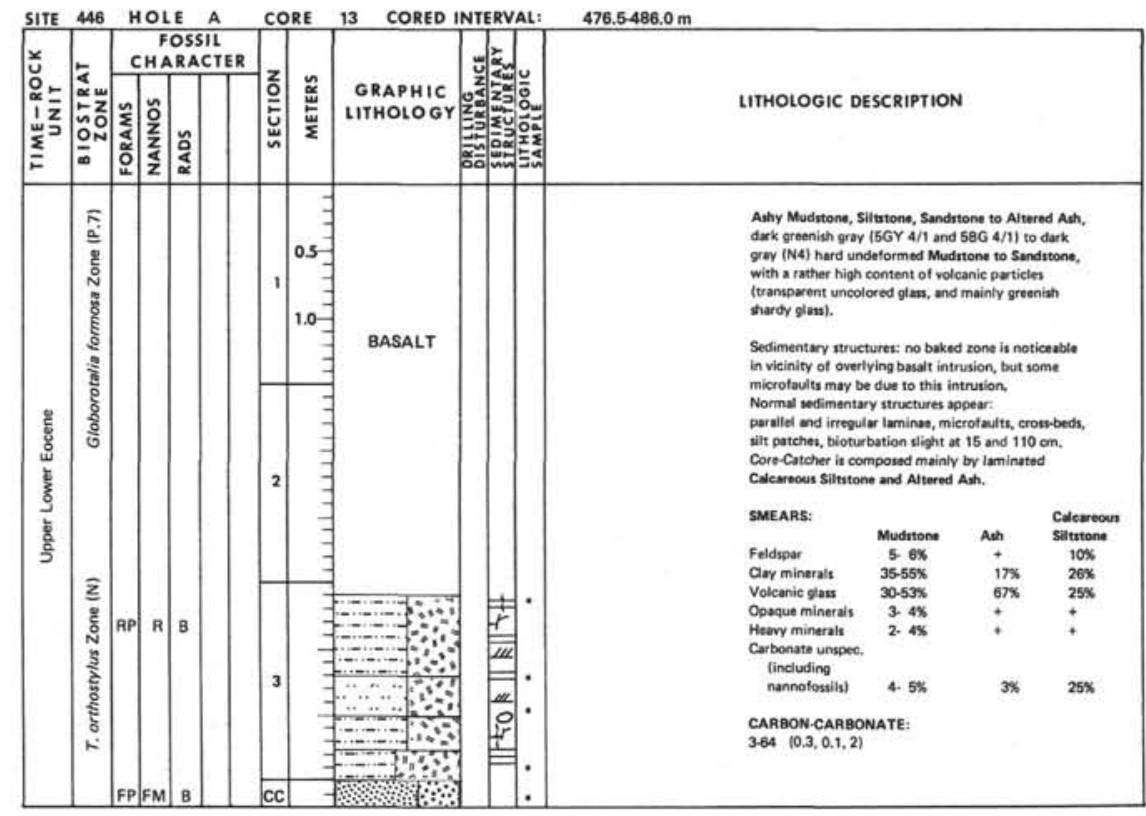




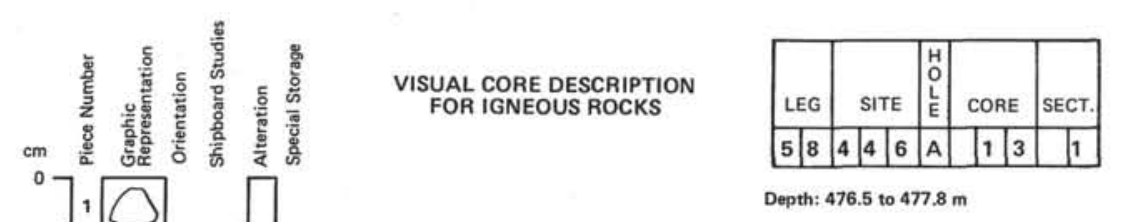

(t) Vesicles $5 \%,<1 \mathrm{~cm}$ filled with calcite and smectite, partly unfilled. 120.133 cm: chill zone at top of next lava flow. $126-133 \mathrm{~cm}$ : vesicles $5 \%$, unfilled.
.

\section{Shipboard Data}

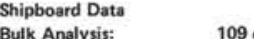

$\mathrm{SiO}_{3}$

$\mathrm{Al}_{2} \mathrm{O}_{3}$

$\mathrm{FeO}^{2} \mathrm{O}_{3}$

$\mathrm{M} O \mathrm{O}$

$\mathrm{CaO}$

$\mathrm{Na}_{2} \mathrm{O}$
$\mathrm{K}_{2} \mathrm{O}$
$\mathrm{TiO}_{2}$

$\mathrm{PiO}_{2} \mathrm{O}_{5}$

$\mathrm{MnO}^{2}$

$\mathrm{LOI}$
$\mathrm{H}_{2} \mathrm{O}^{+}$
$\mathrm{H}_{2} \mathrm{O}^{-}$

$\mathrm{H}_{2} \mathrm{O}$
$\mathrm{CO}_{2}$
$\mathrm{Cr}^{2}$
$\mathrm{Ni}$
$\mathrm{Sr}$
$\mathrm{Zr}$

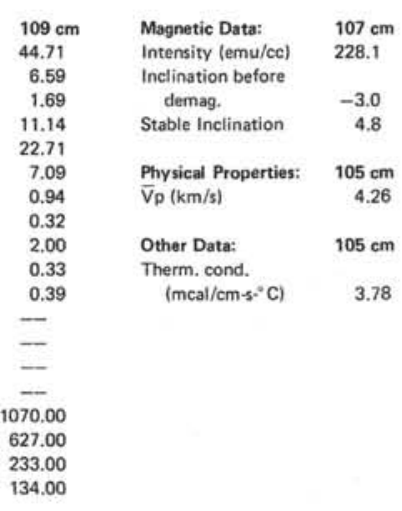

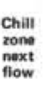

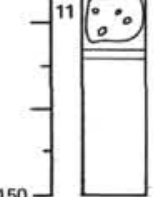

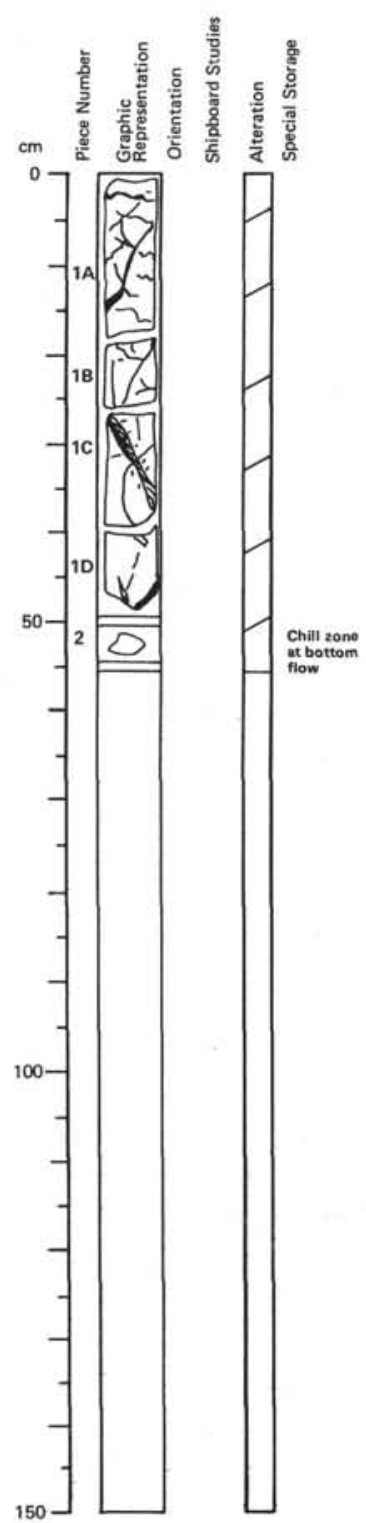

CORE DESCRIPTION

FOR IGNEOUS ROCKS

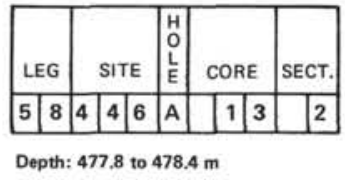

Visual Description

, fine-grained, dark gray, vesicular. Vesicles $15.20 \%,<1.2 \mathrm{~mm}$ clay. Numerous calcite veins with thicknesses up to $15 \mathrm{~mm}$. $\mathrm{m}$ : top of chill zone. 


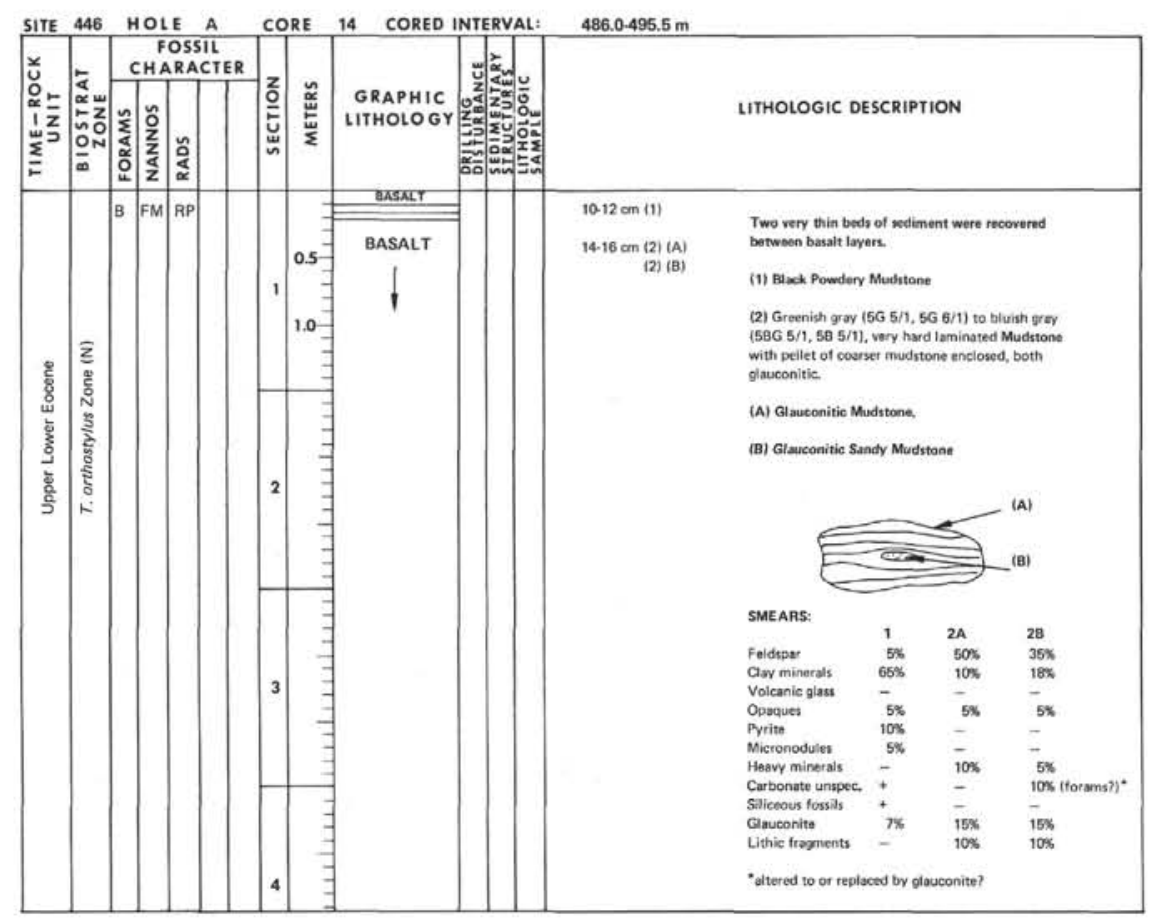



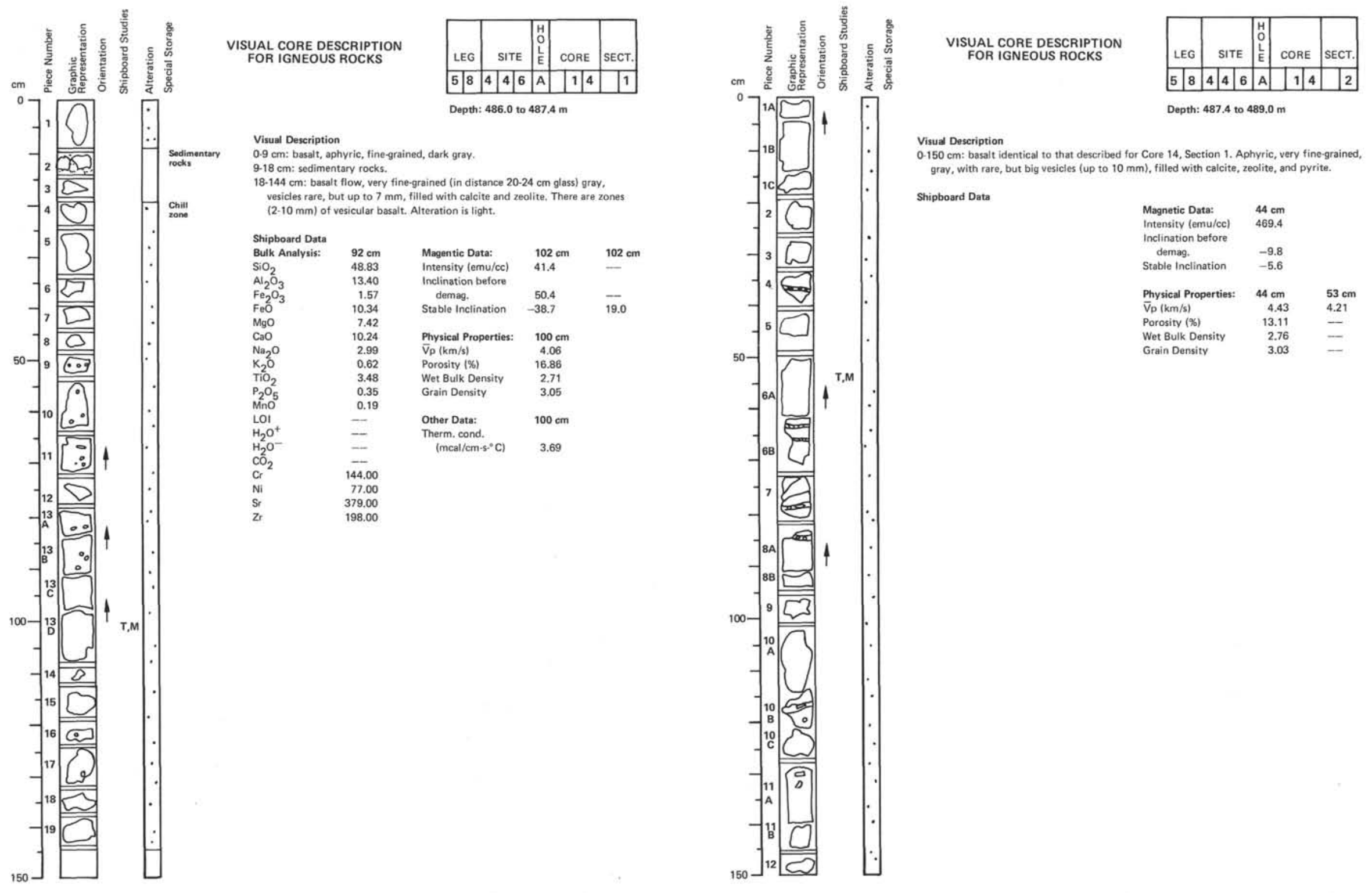


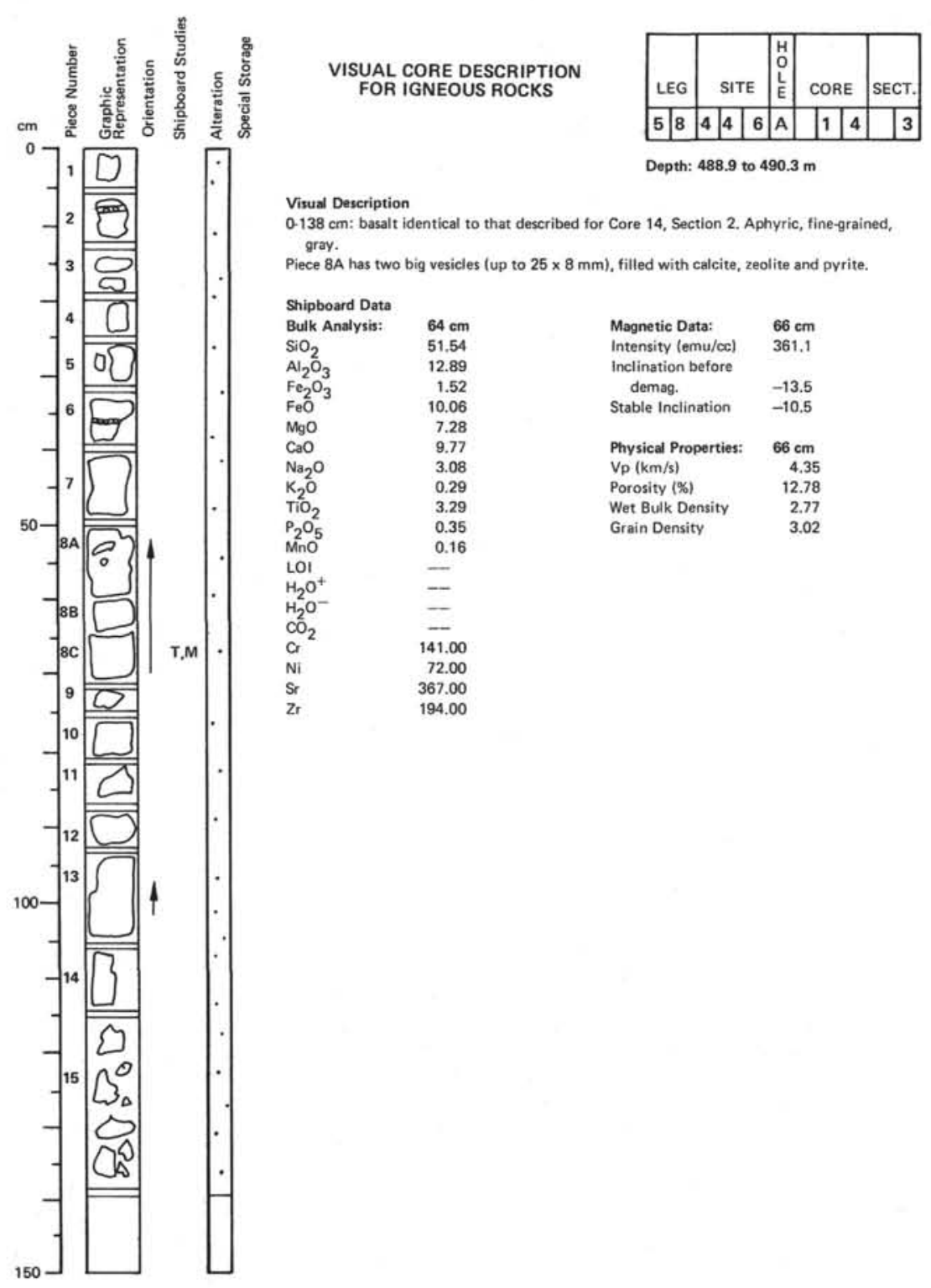



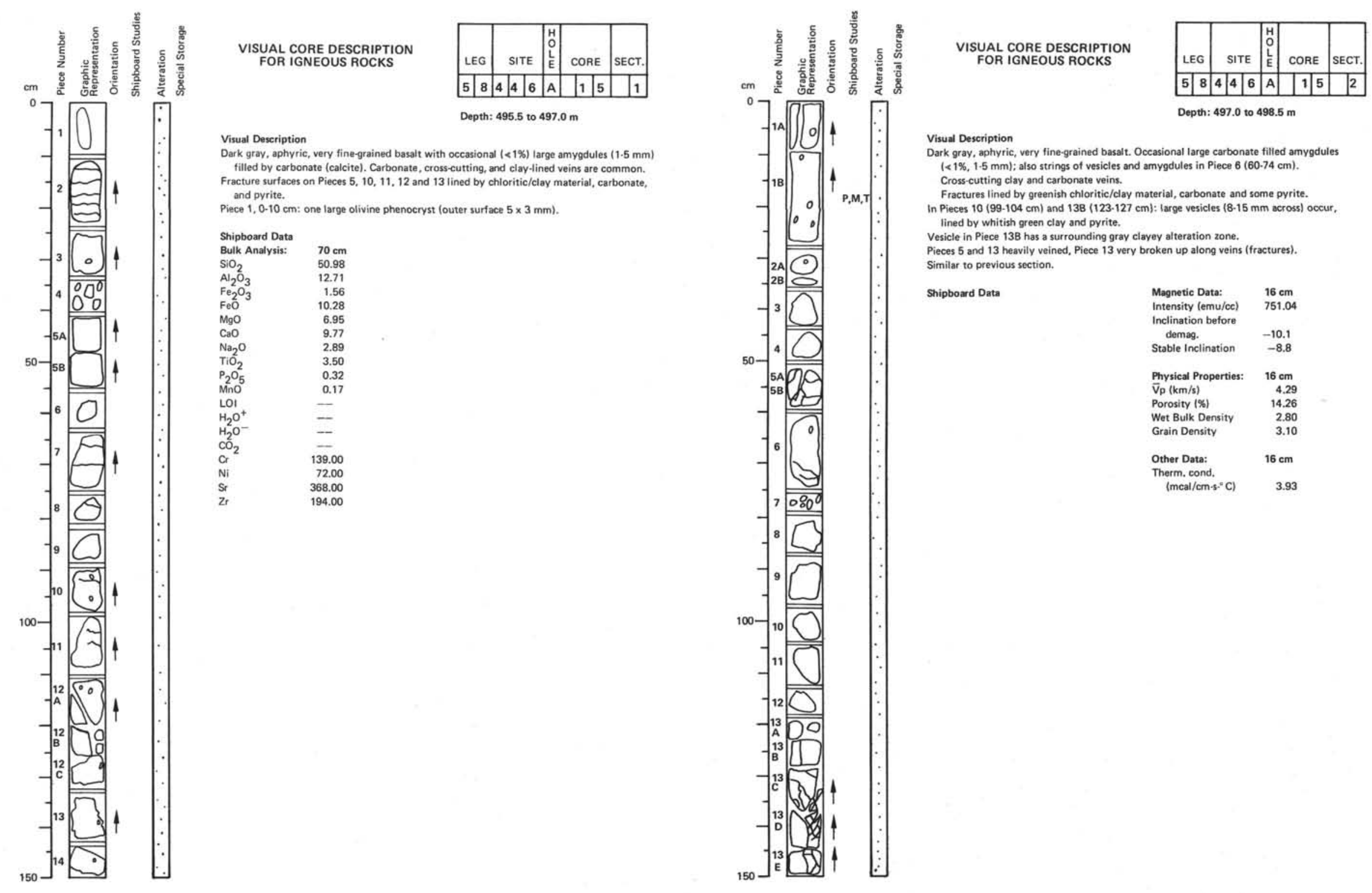

Visual Description

列 $(<1 \%, 1.5 \mathrm{~mm})$; also strings of vesicles and amygdules in Piece $6(60.74 \mathrm{~cm})$. Fractures lined by greenish chloritic/clay material, carbonate and some pyrite. In Pieces $10(99-104 \mathrm{~cm})$ and 138 (123.127 cm): large vesicles $(8.15 \mathrm{~mm}$ scross) occur, lined by whitish green clay and pyrite.

Pesicee in Piece 138 has a surrounding gray clavev alteration zone.
Pieces and 13 heavily veined, Piece 13 very broken up along veins (fractures). Similar to previous section.

Shipboard Data

\begin{tabular}{|c|c|}
\hline & \\
\hline $\begin{array}{l}\text { Intensity (emu/cce } \\
\text { Inclination before }\end{array}$ & 751.04 \\
\hline $\begin{array}{l}\text { Inclination before } \\
\text { demag. }\end{array}$ & \\
\hline Stable Inclination & \\
\hline & \\
\hline & \\
\hline & 14.2 \\
\hline & \\
\hline Grain Dens & 3. \\
\hline & \\
\hline $\begin{array}{l}\text { Therm. cor } \\
\text { (mcal//or }\end{array}$ & \\
\hline
\end{tabular}




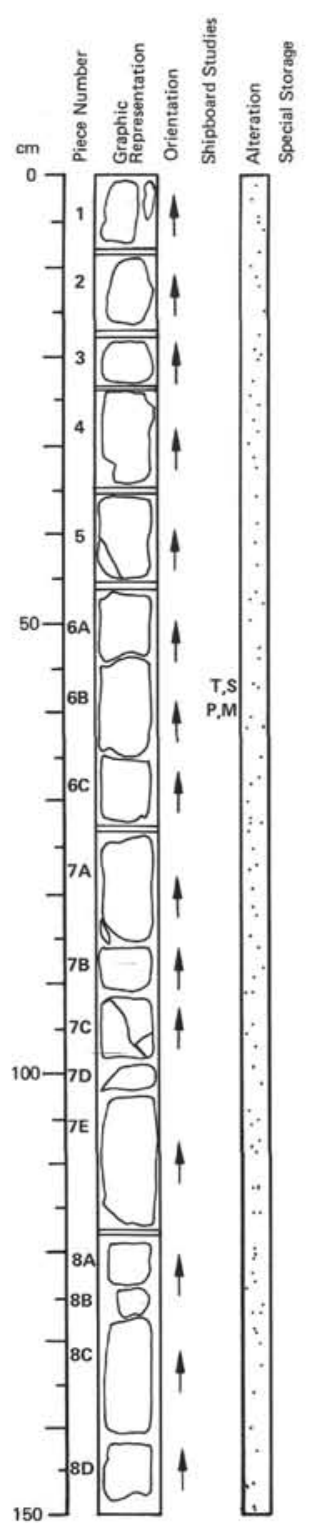

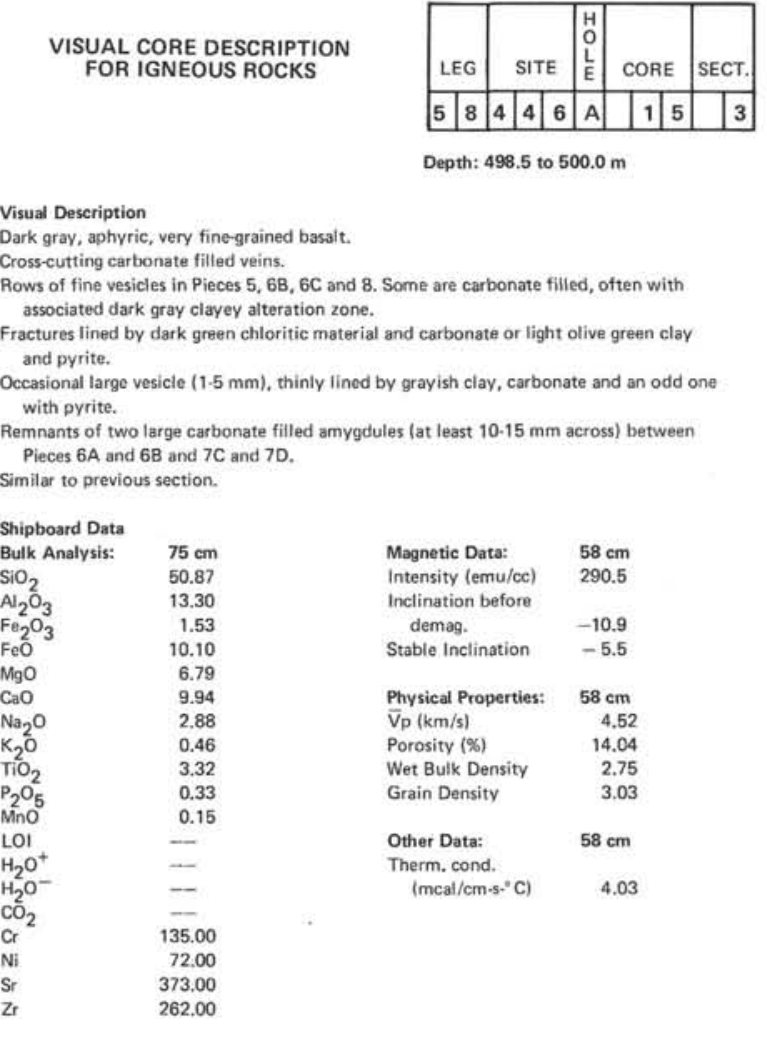

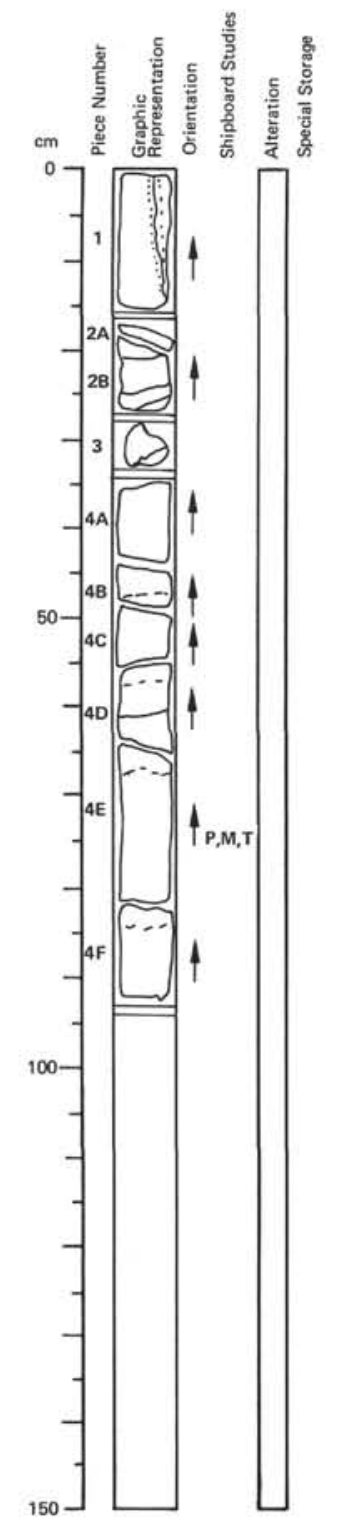
VISUAL CORE DESCRIPTION
FOR IGNEOUS ROCKS

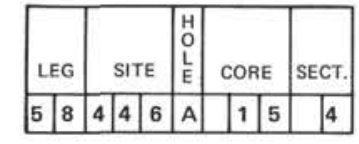
Depth: 500.0 to $500.9 \mathrm{~m}$

Visual Description

Dark gray, aphyric, very fine-grained, basat.

Cross cutting calcite veins and rows of vesicles (often carbonate filled and with alteration

Occasional large vesicles $(10-20 \mathrm{~mm})$ present, lined by olive green clay and pyrite.

D. $3.33 \mathrm{~cm}$ : dark fracture surface covered by fine-grained pyrite. Similar occurrence on lower surface of Piece $48,48 \mathrm{~cm}$.

-.-- rows of vesicles,

Shipboard Data

\begin{tabular}{|c|c|}
\hline $\begin{array}{l}\text { Magnetic Data: } \\
\text { Intensity (emu/c) }\end{array}$ & $\begin{array}{l}73 \mathrm{~cm} \\
331.1\end{array}$ \\
\hline $\begin{array}{l}\text { Intensity (emu/cc) } \\
\text { Inclination before }\end{array}$ & \\
\hline $\begin{array}{l}\text { demag. } \\
\text { Stable Inclination }\end{array}$ & -7.6 \\
\hline Stable Inclination & -7.8 \\
\hline $\begin{array}{l}\text { Physical Properties: } \\
\bar{V}_{0}(\mathrm{~km} / \mathrm{s})\end{array}$ & $73 \mathrm{~cm}$ \\
\hline$V_{p}(\mathrm{~km} / \mathrm{s})$ & 4.60 \\
\hline Porosity (\%) & 10.34 \\
\hline Wet Bulk Density & 2.80 \\
\hline Grain Density & 3.00 \\
\hline Other Data: & $73 \mathrm{~cm}$ \\
\hline $\begin{array}{l}\text { Therm. cond. } \\
\text { (mcal/cm-s: c) }\end{array}$ & 4.18 \\
\hline
\end{tabular}

\footnotetext{
-
} 


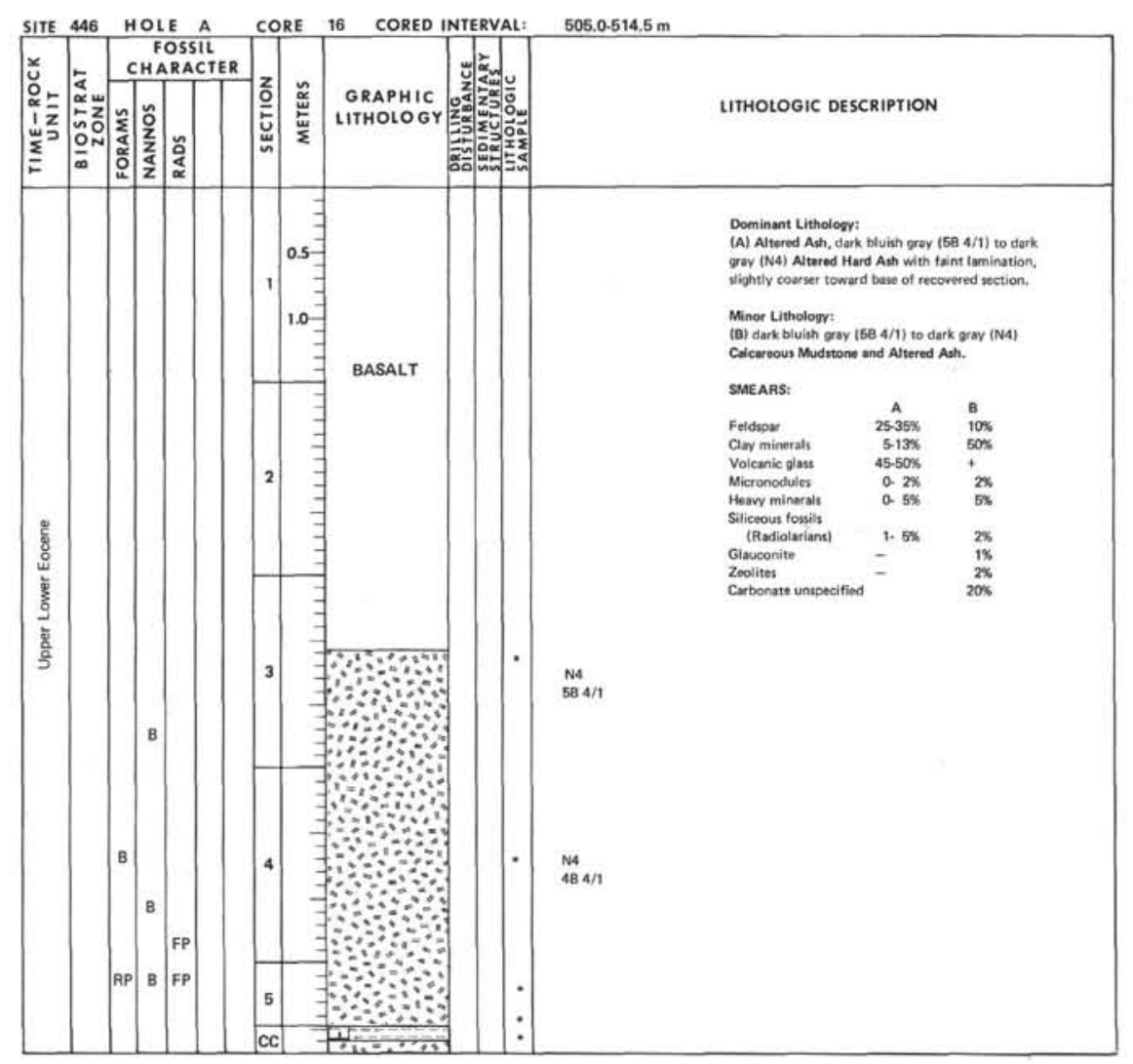



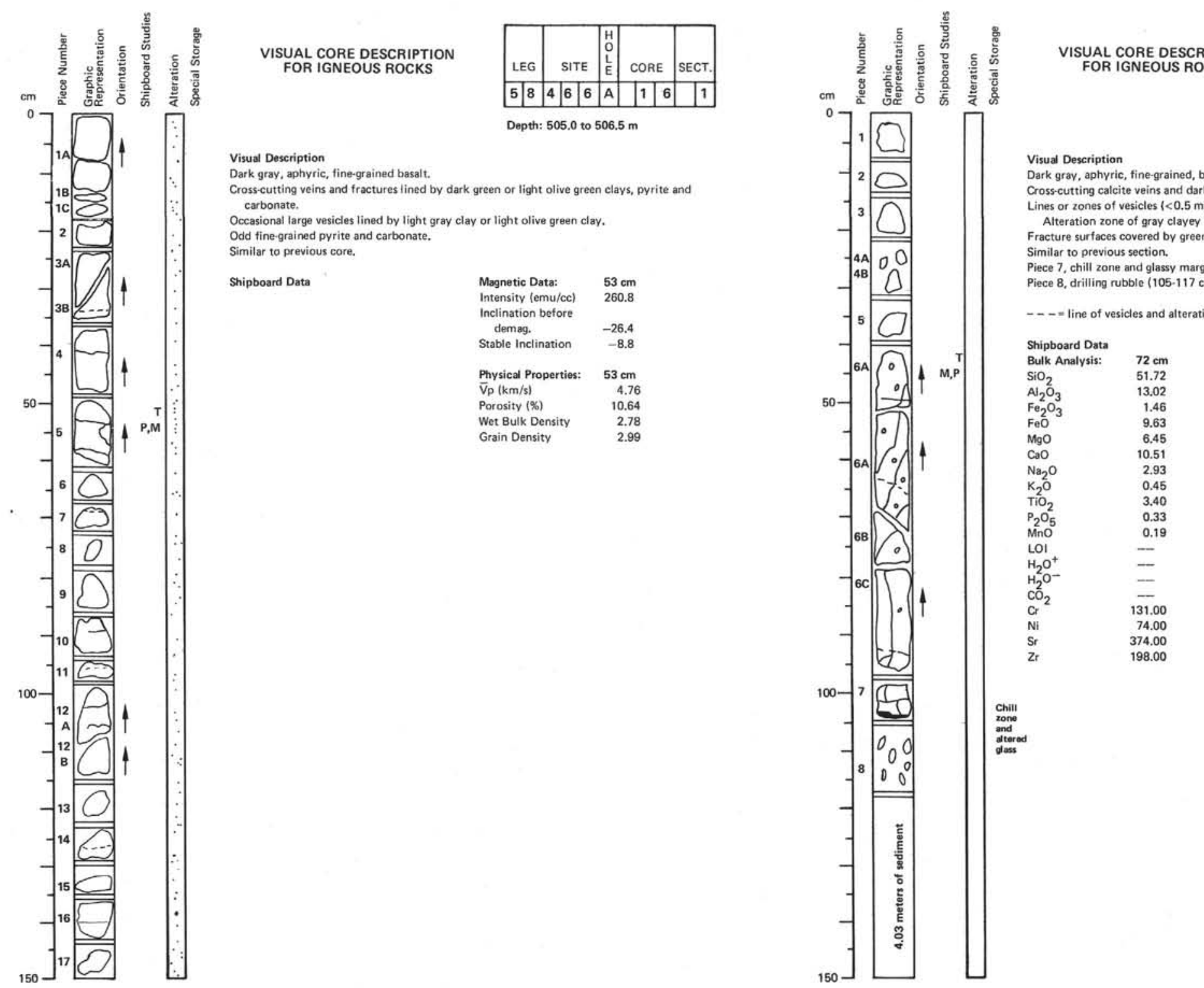

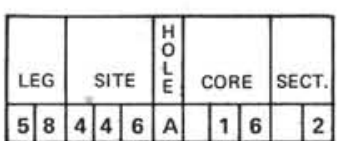

Depth: 506.5 to 507.7

Dark grav, aphyric, fine-grained, basalt.

Des

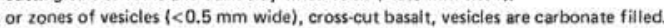

.

51.72
13,02

1.46

10.51
2.93

0.45

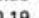

$\overline{-}$

$\overline{131.00}$

4.00

$\begin{array}{lc}\text { Magnetic Data: } & 44 \mathrm{~cm} \\ \text { IItensiti (emu/c) } & 626.2 \\ \text { Inclination before } & \\ \text { demag. } & -4.4 \\ \text { Stable Inclination } & -2.0 \\ & \\ \text { Physical Properties: } & 44 \mathrm{~cm} \\ \text { Vop (km/s) } & 4.25 \\ \text { Porosity (s) } & 14.80 \\ \text { Wet Bulk Density } & 2.74 \\ \text { Grain Density } & 3.04\end{array}$

Wet Bulk Density $\quad 2.74$ 


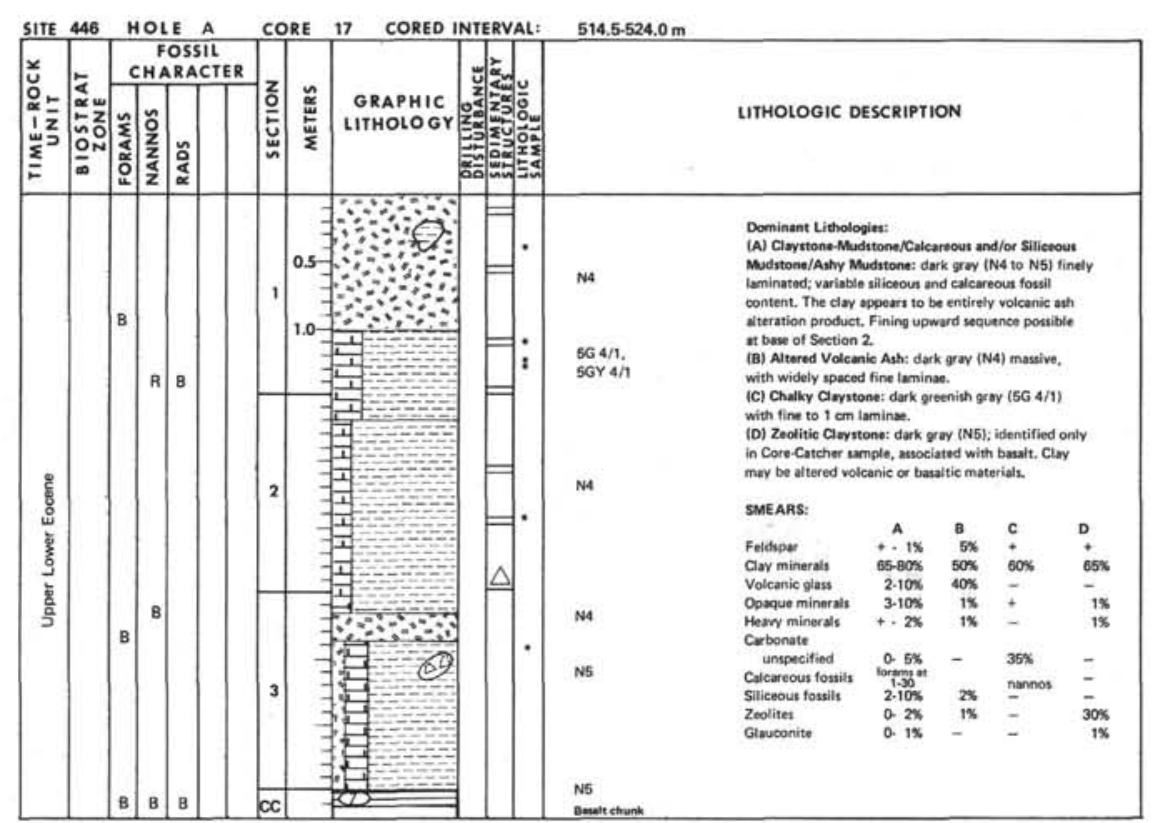




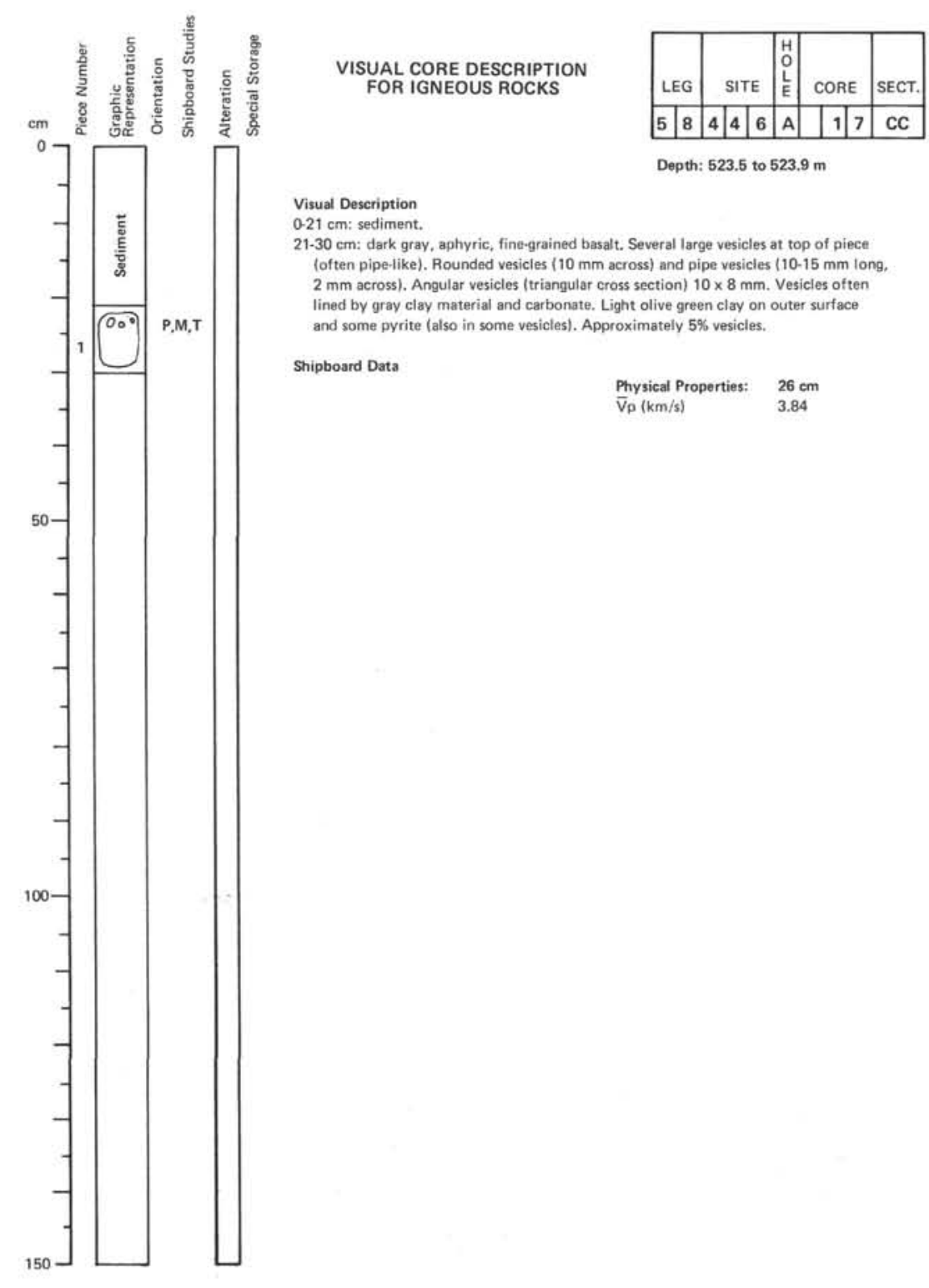




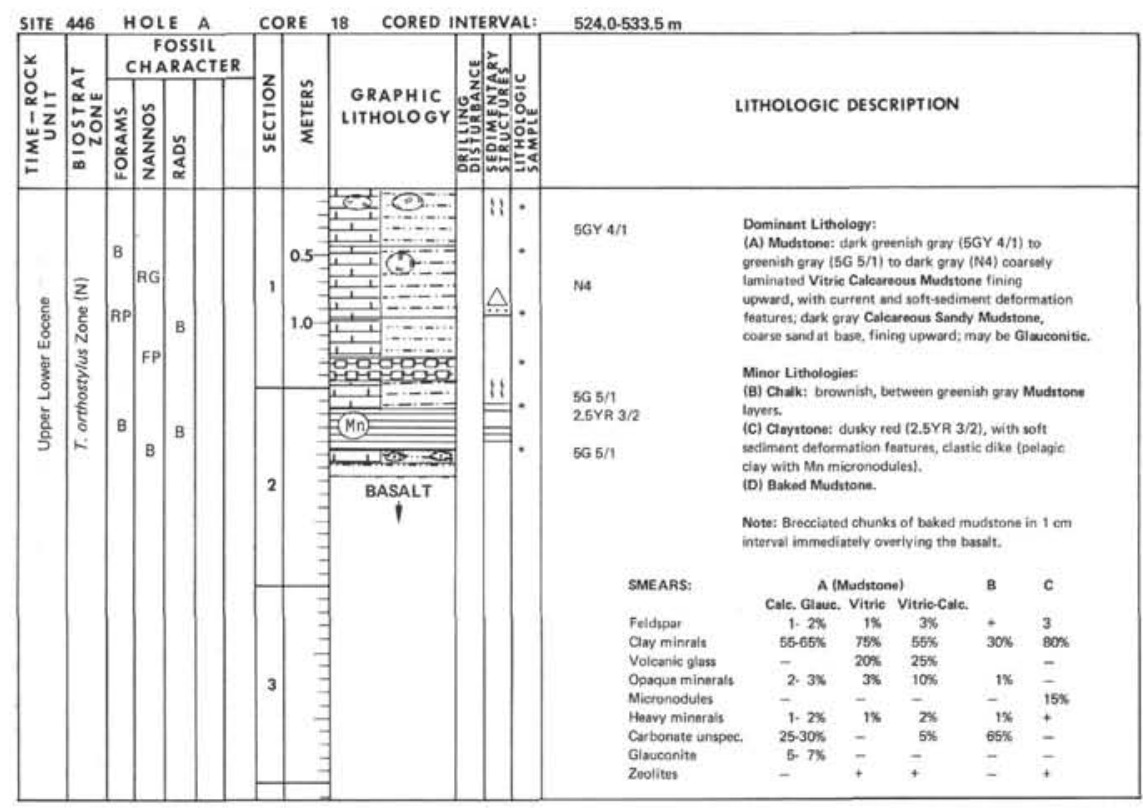



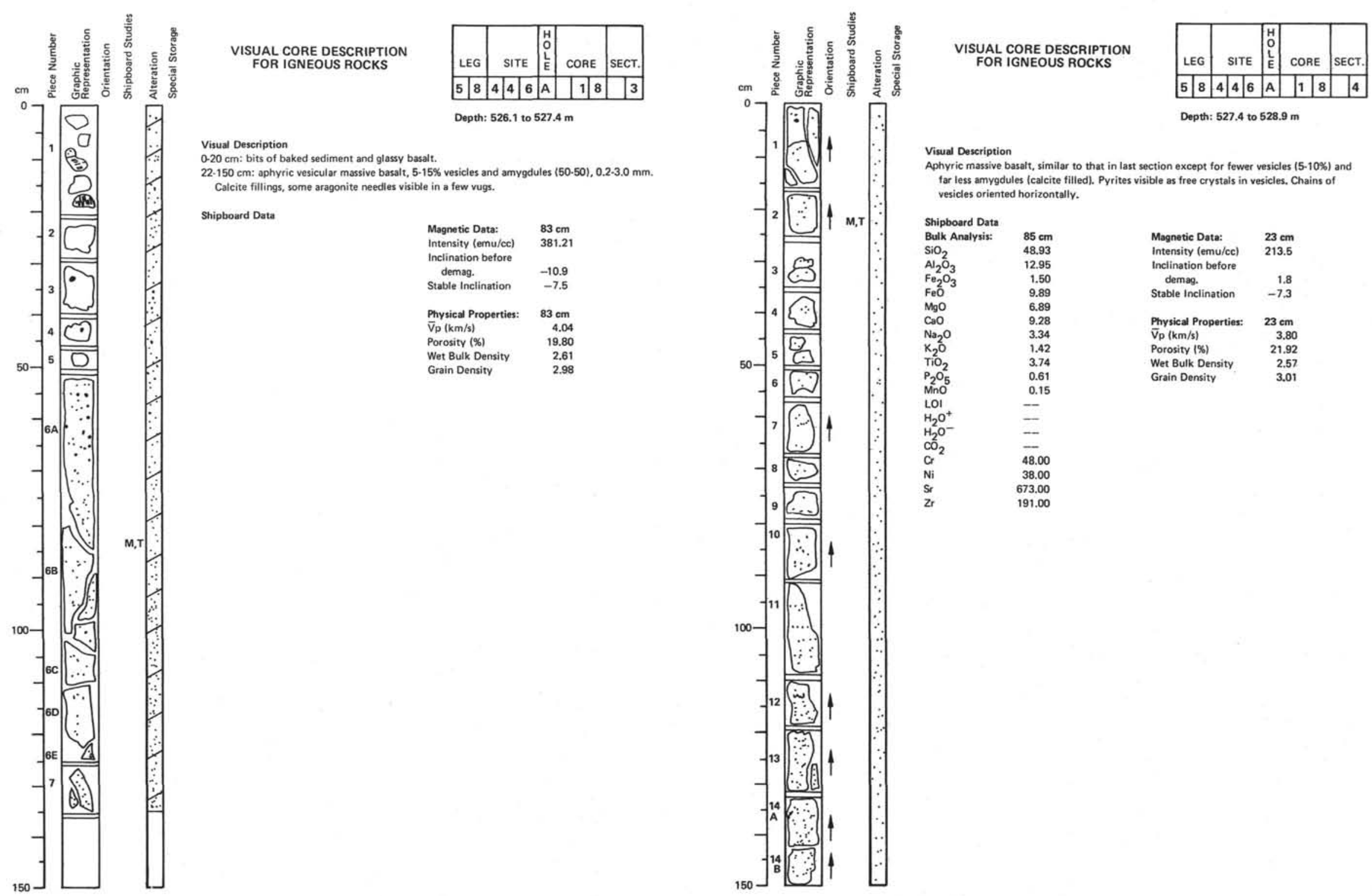

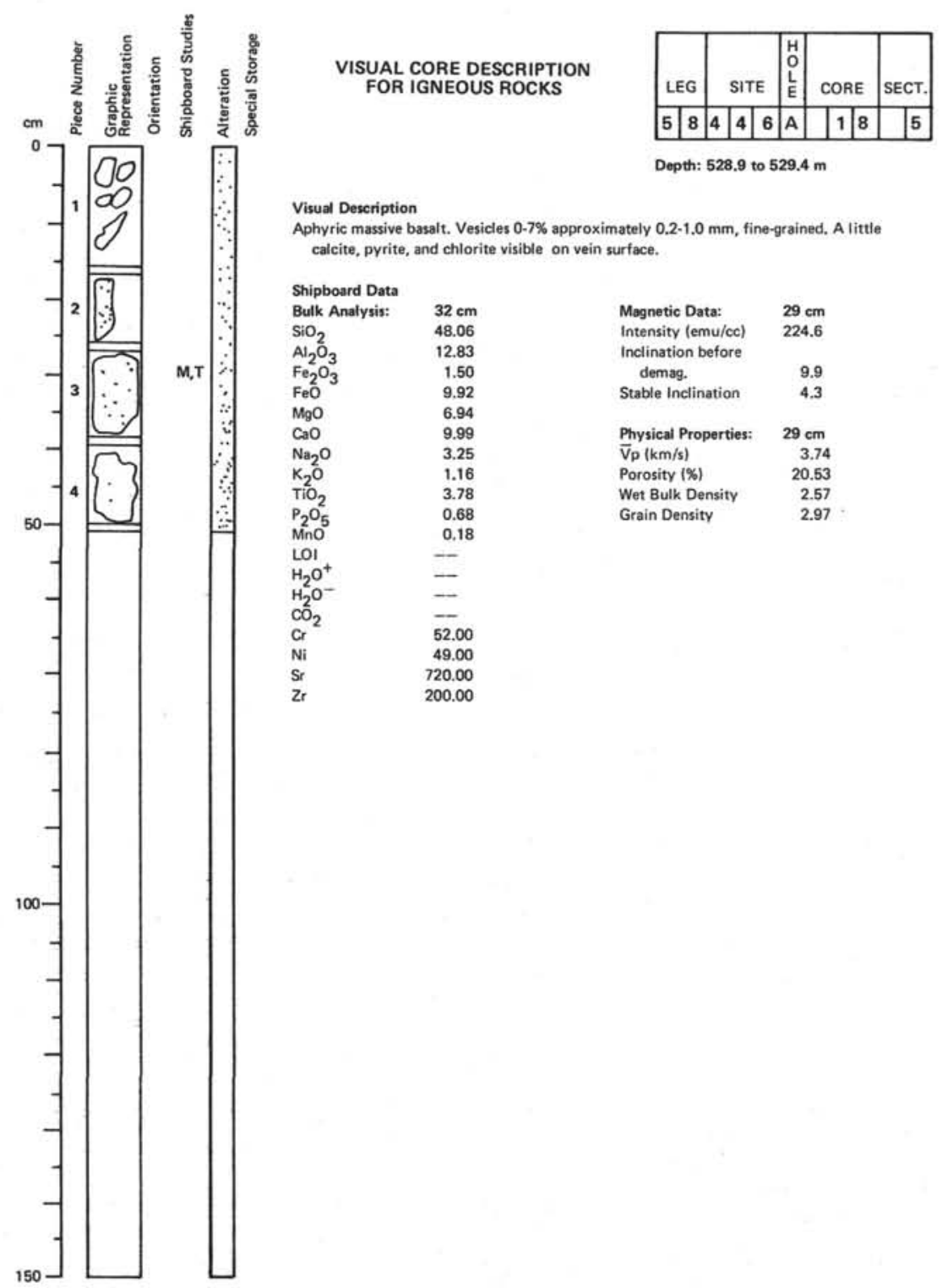


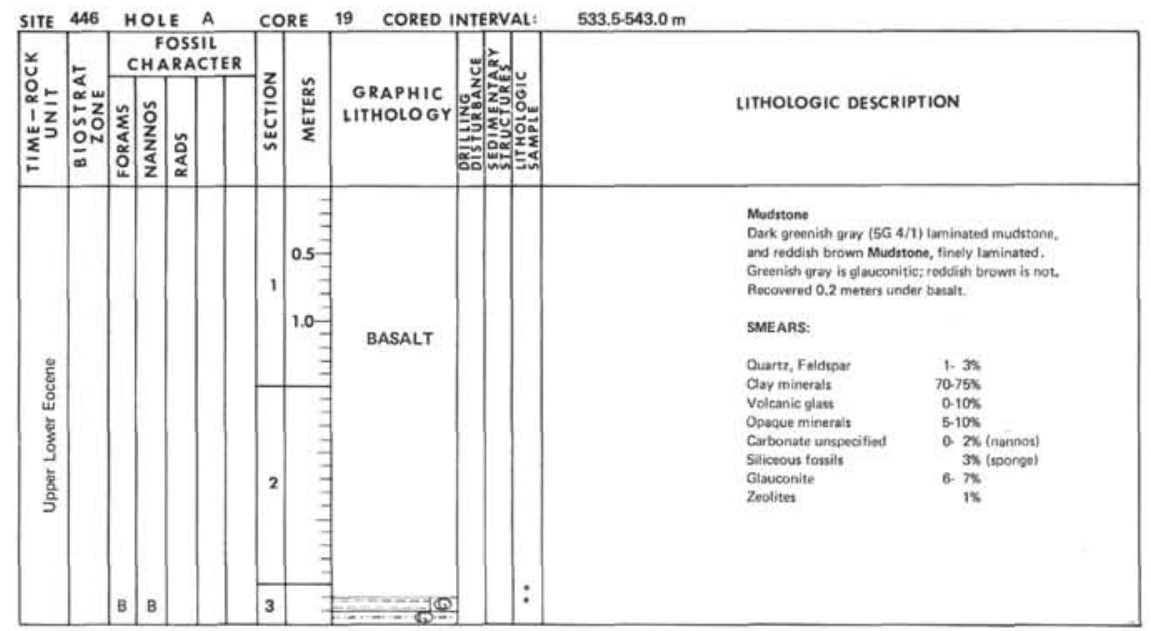



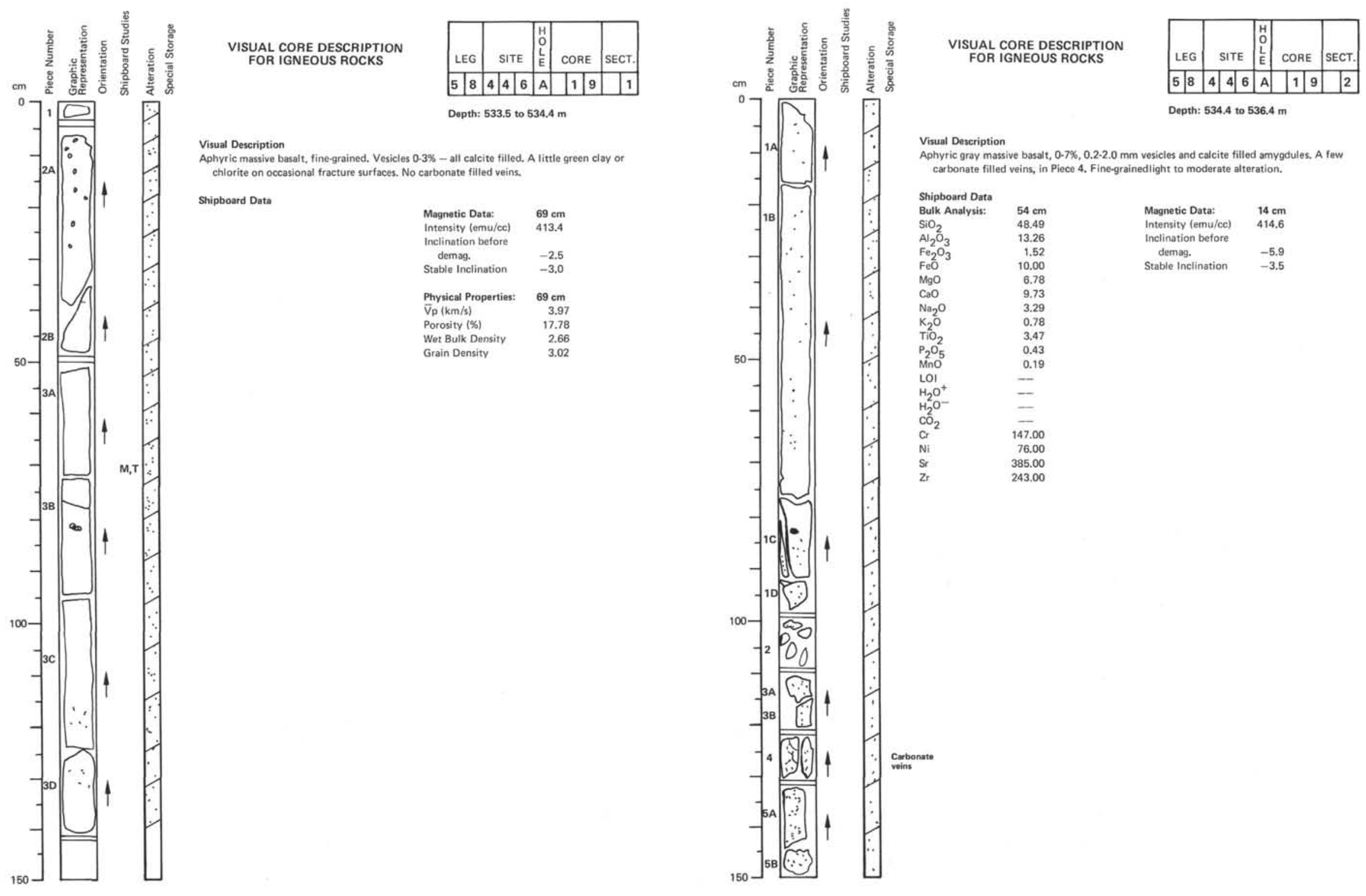

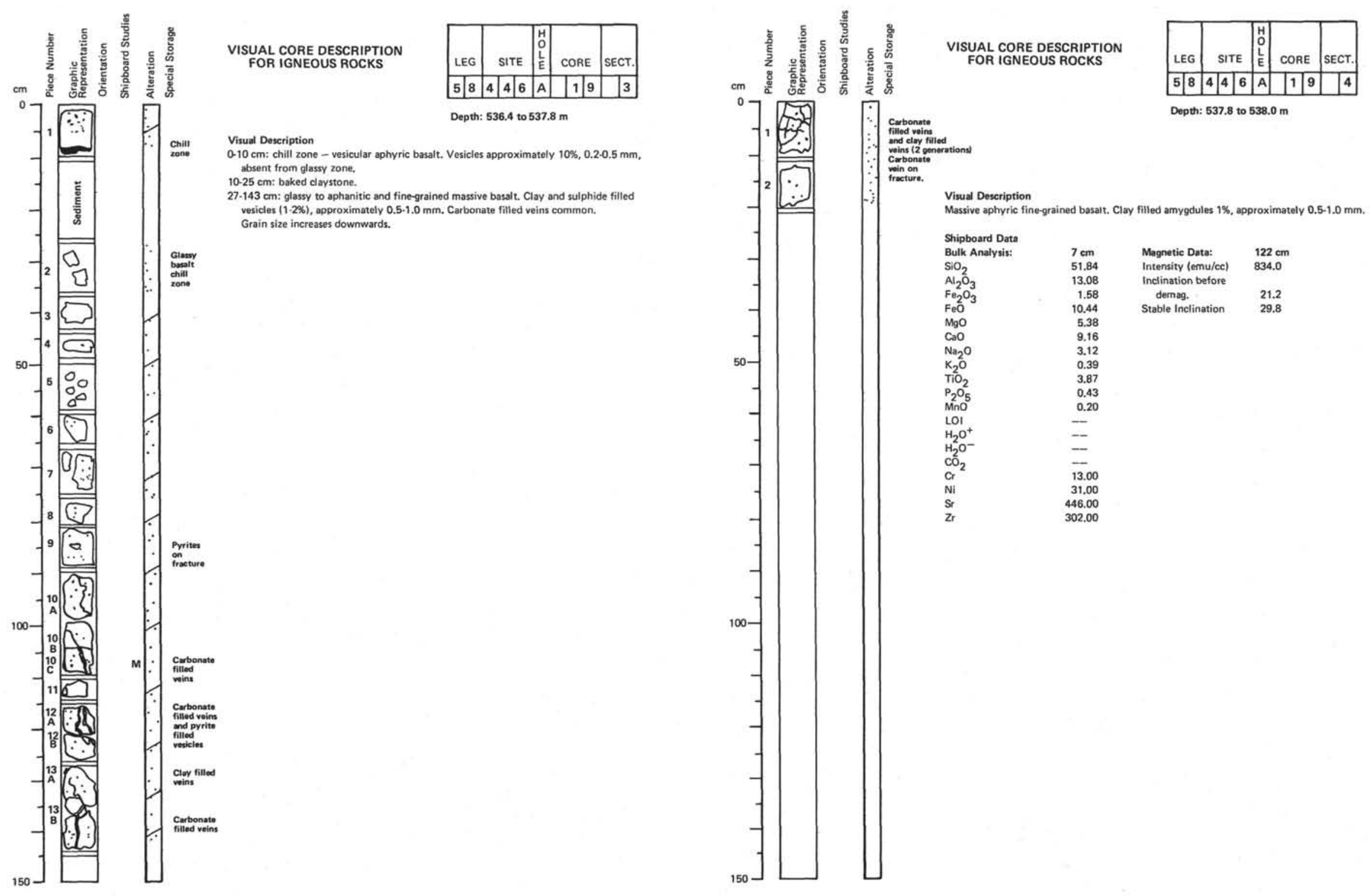

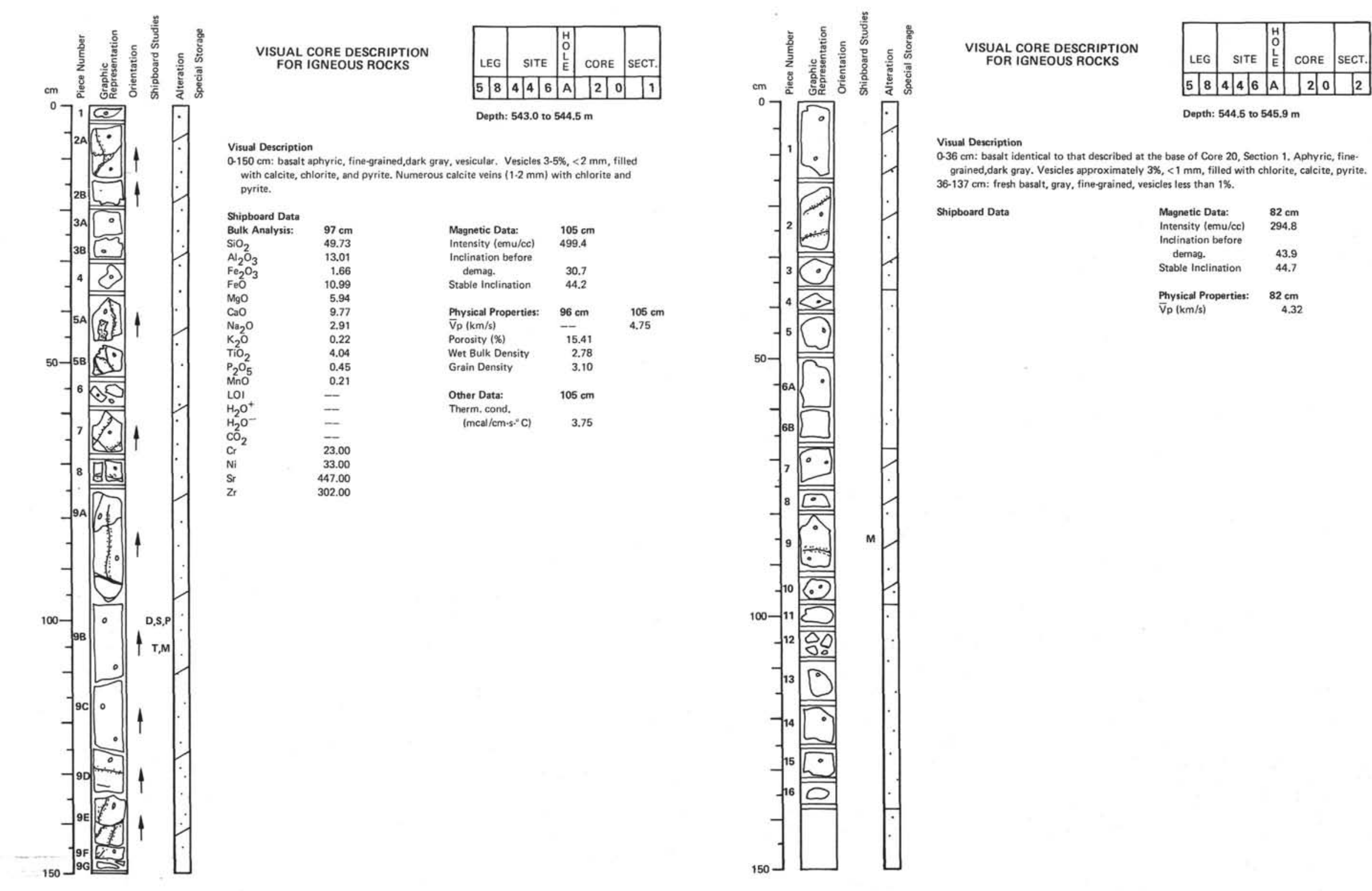

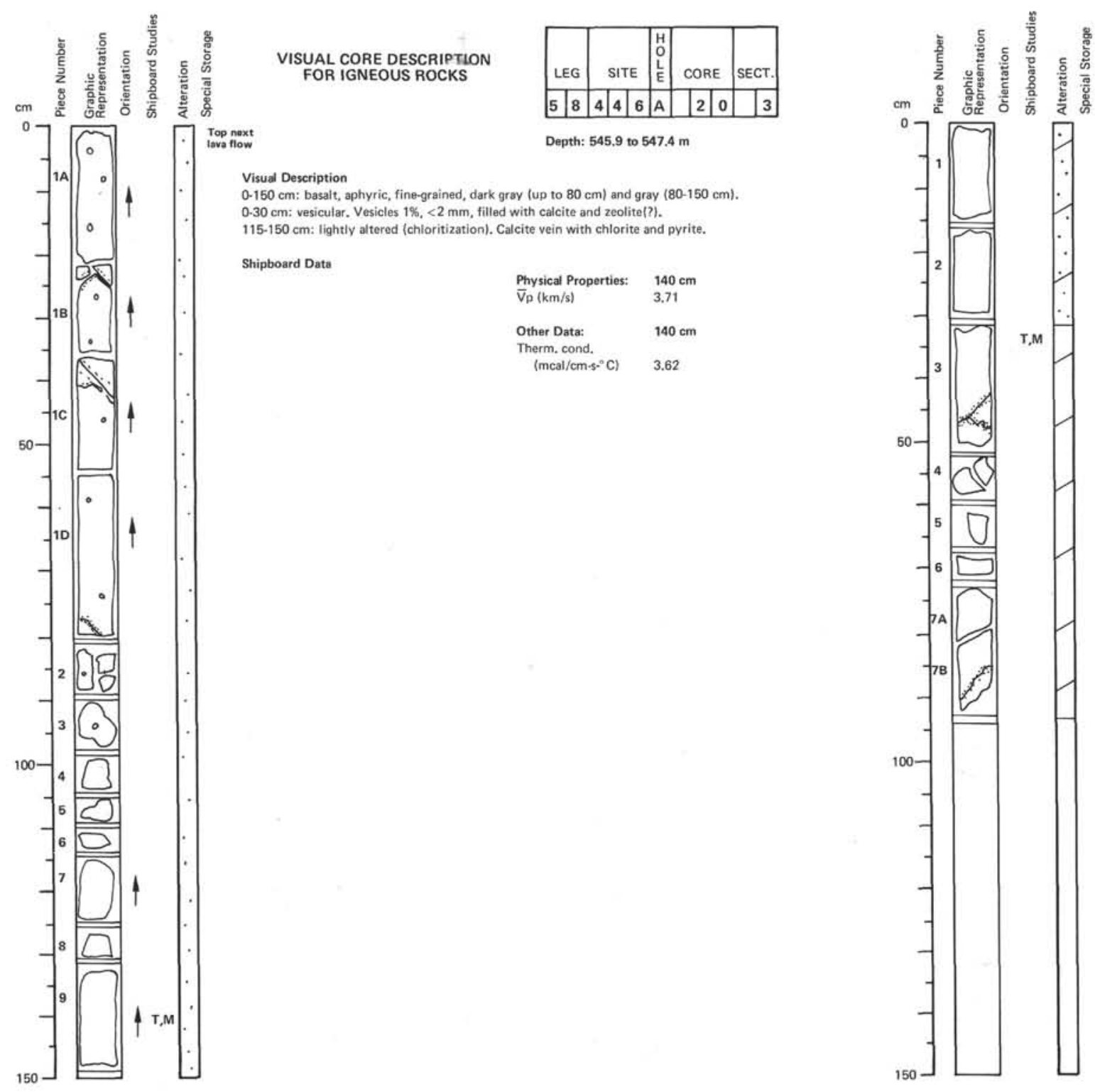
VISUAL CORE DESCRIPTION

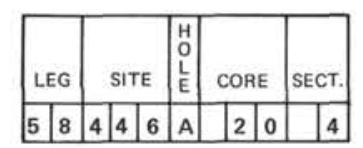

Visual Description

Visual Description altered, Basalt aphyric, fine-grained, dark gray (greenish). Coarser-grained, then befor Alteration - chloritization.

Shipboard Data

Magnetic Data: Inclintion belore Stable Inclination

Physical Properties: $34 \mathrm{~cm}$ Porosity (\%) $\quad 20.89$ Grain Density $\quad 2.60$ $34 \mathrm{~cm}$

Imcal/cm-s: 3.03 

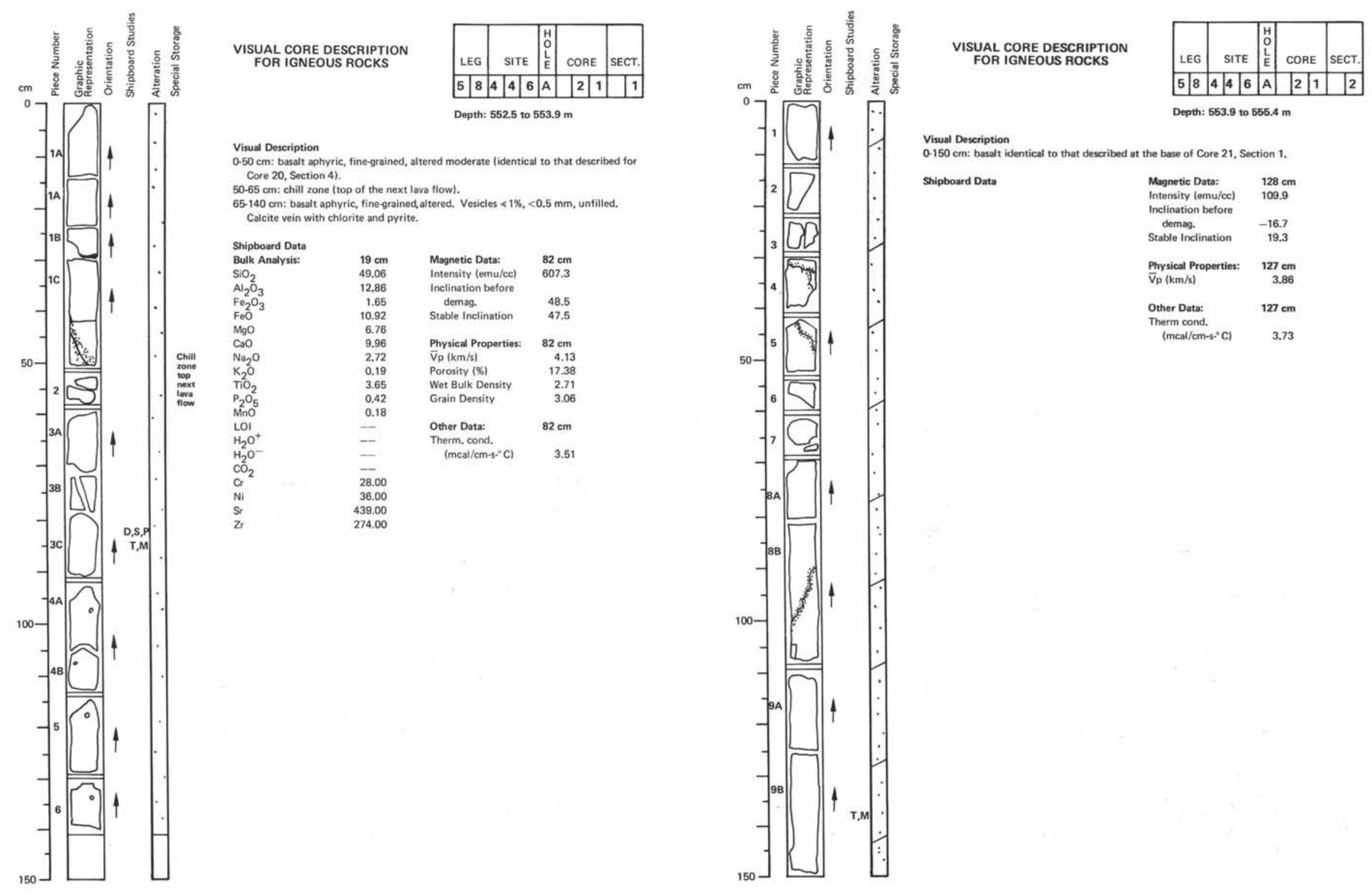

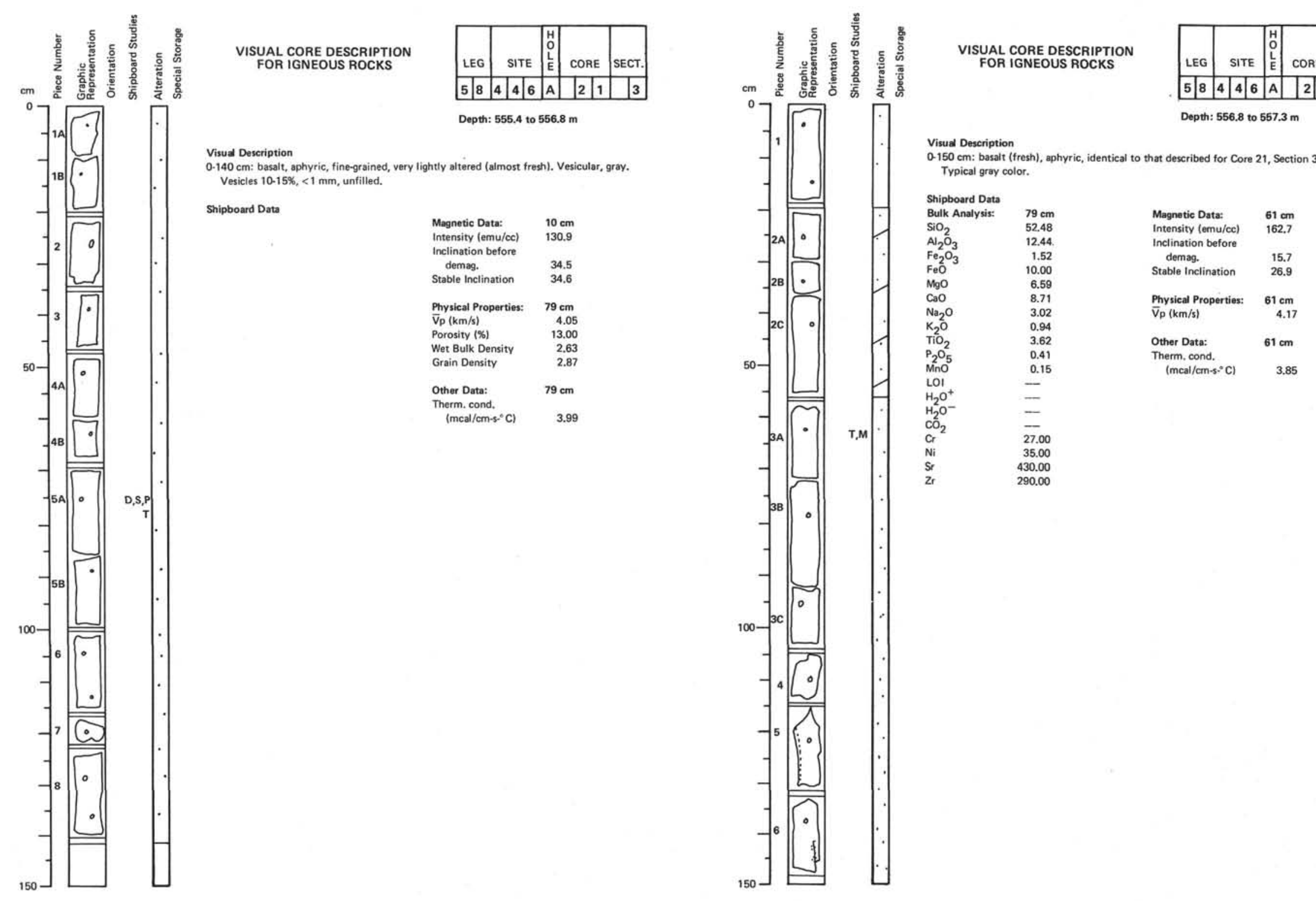

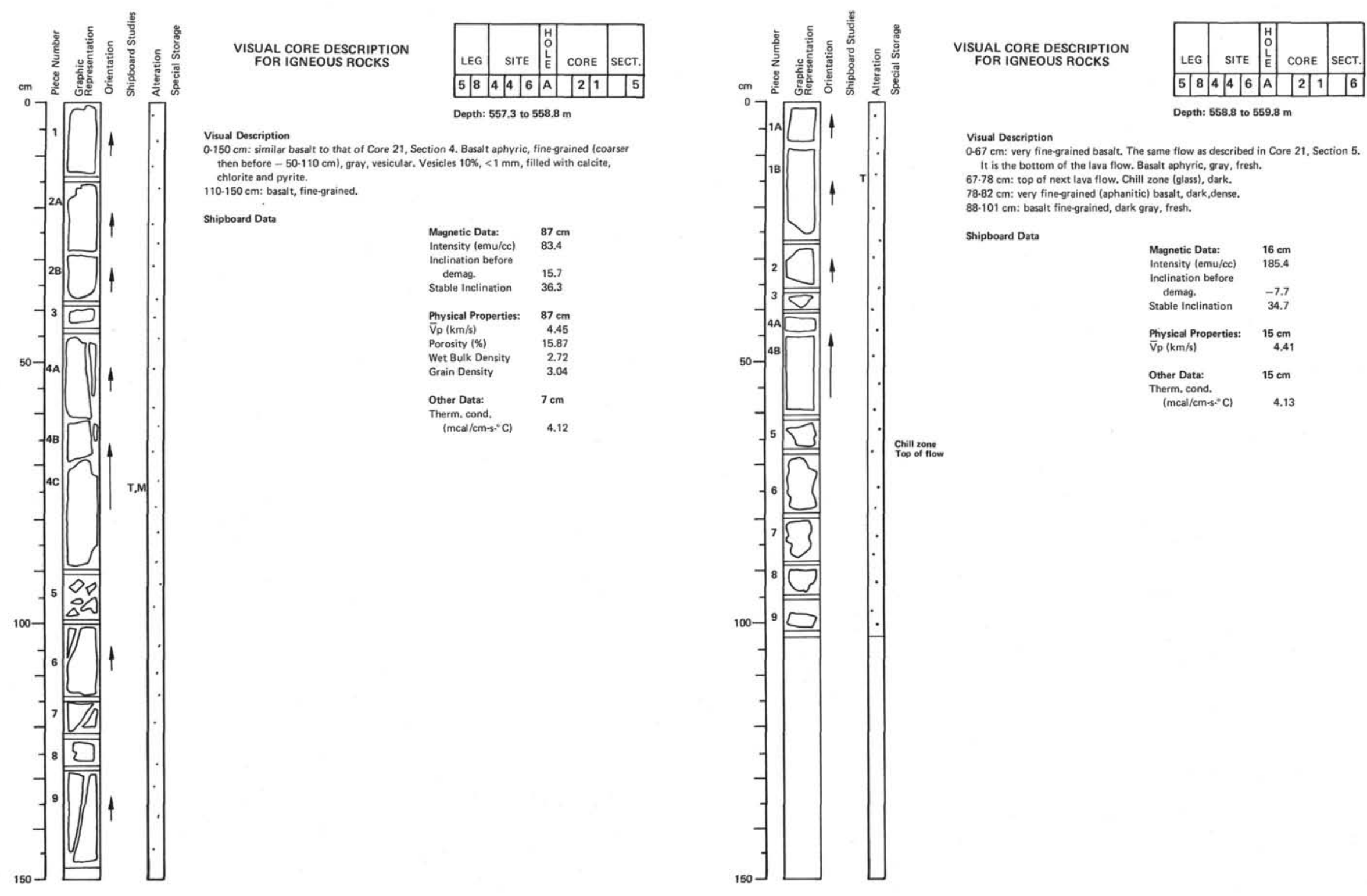

Visual Description

$\mathrm{cm}$ : very fine-grained basalt. The same flow as described in Core 21. Section 5. Hit is the bottom of the lava flow. Basalt aphyric, grav, fresh, $78.82 \mathrm{~cm}$ : very fine $88.101 \mathrm{~cm}$ : basalt fine-grained, dark gray, fresh.

Shipboard Data

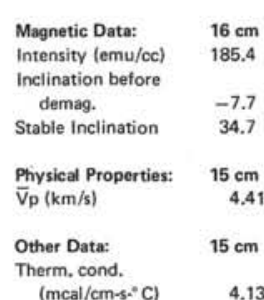

op of flow

(mcal/cm-s." C) $\quad 4.13$




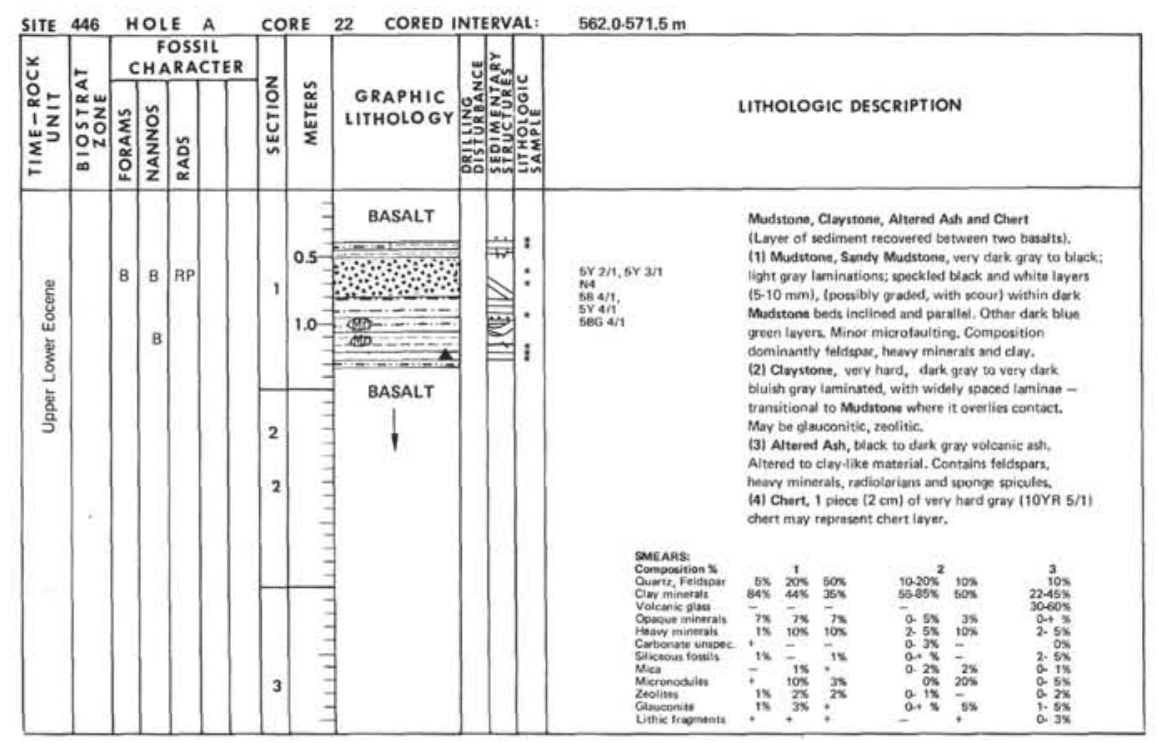



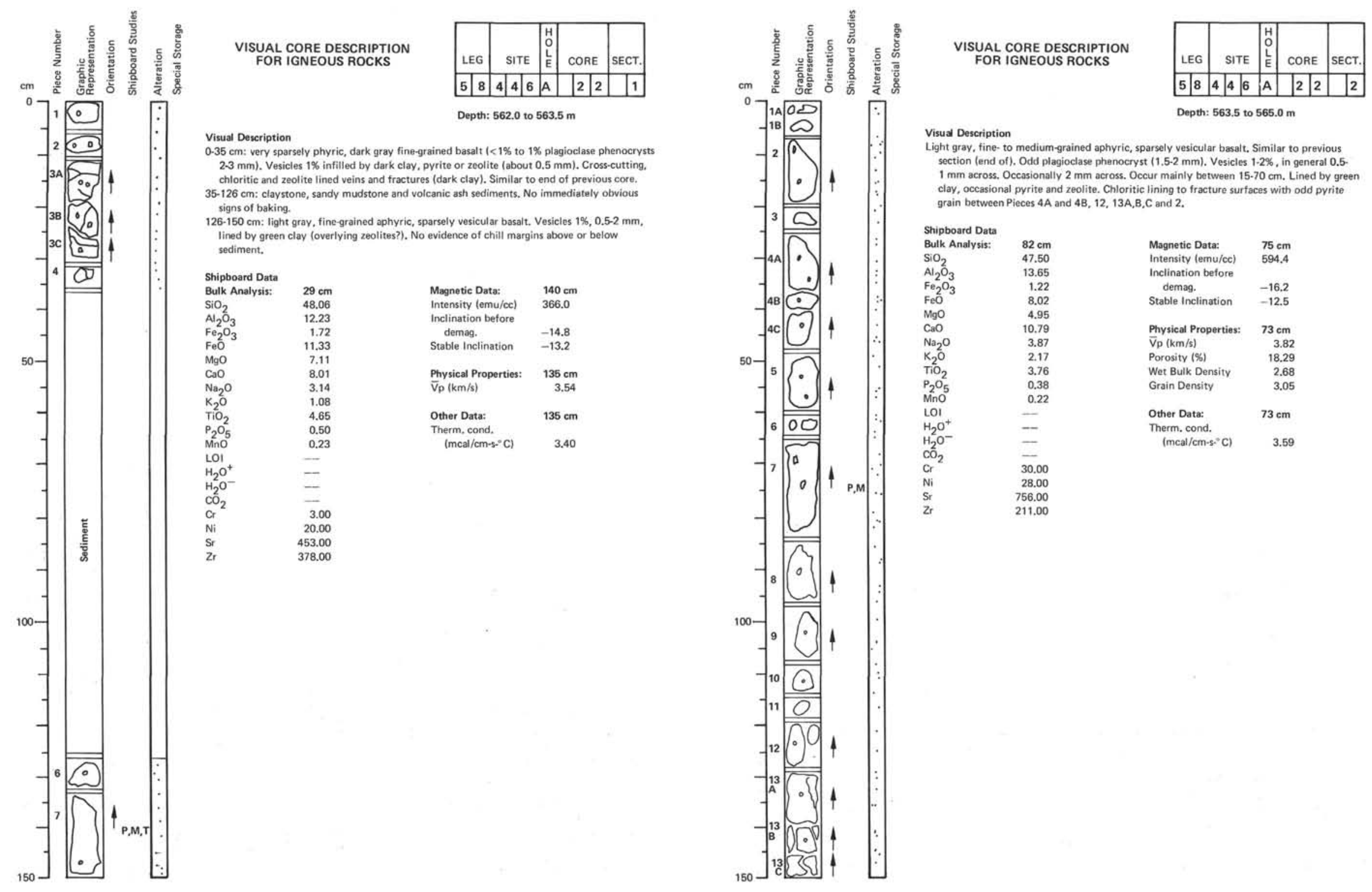

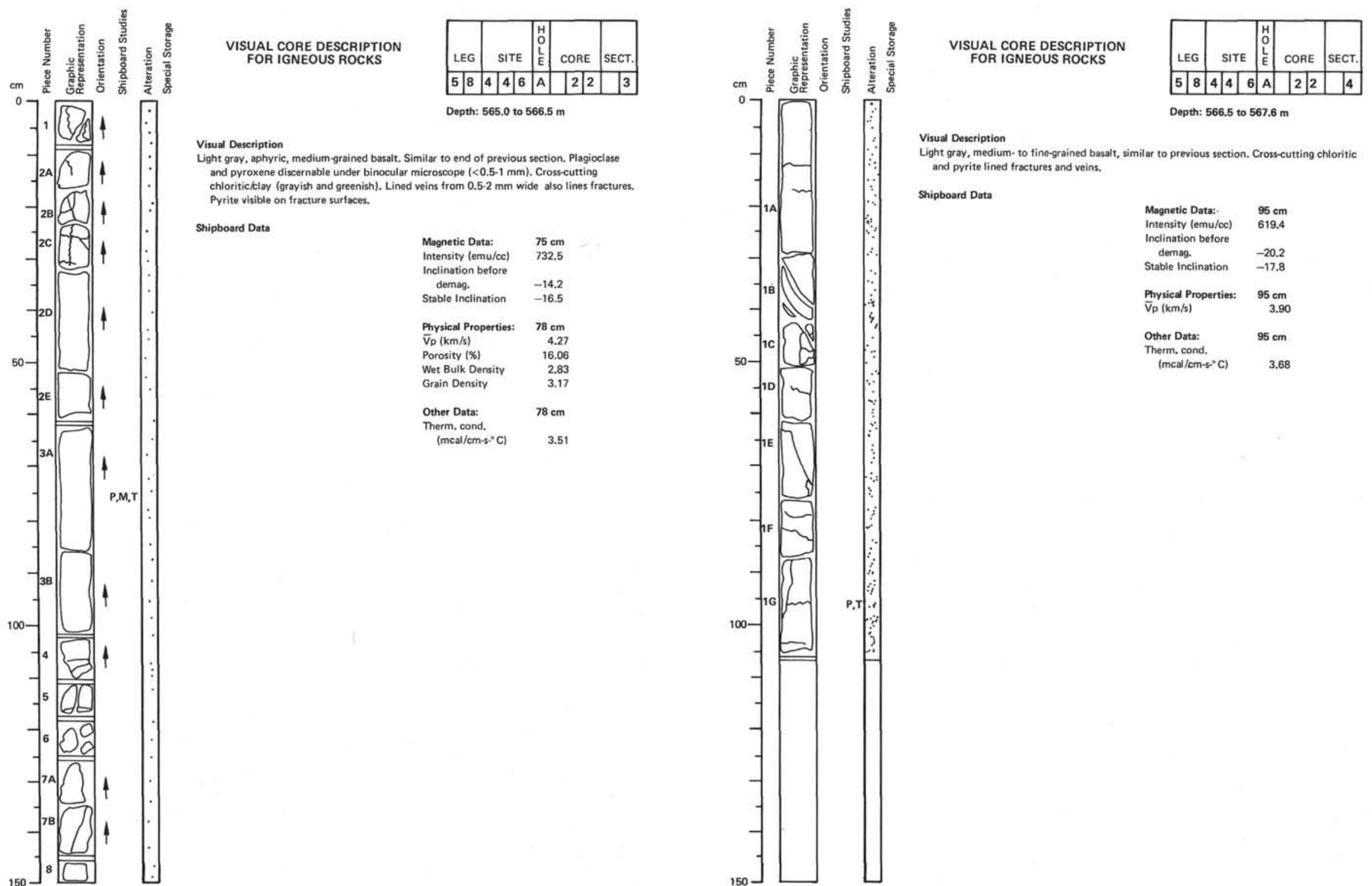
Visual Description
Light gray, aphyric, medium-grained basalt. Similar to end of previous section. Plagioclase
and pyroxene discernable under binocular microscope $(<0.5-1 \mathrm{~mm}$ ). Cross-cuutting chloriticklay (grayish and greenish). Lined veins from $0.5-2 \mathrm{~mm}$ wide also lines fractures. Pyrite visible on fracture surfaces. \begin{tabular}{|l|l|l|l|l|l|l|l|l|}
\hline 5 & 8 & 4 & 4 & 6 & A & 2 & 2 & \\
\hline
\end{tabular} Depth: 565.0 to 566.5

Shiphound Date

\begin{tabular}{lr} 
Magnetic Data: & $75 \mathrm{~cm}$ \\
Intensity (emu/cc) & 732.5 \\
Inclination before & -14.2 \\
$\quad$ demag. & -16.5 \\
Stable Inclination & -16.5 \\
& \\
Phrysical Properties: & $78 \mathrm{~cm}$ \\
\hline Vyp (km/s) & 4.27 \\
Porosity (\$) & 16.06 \\
Wet Bulk Density & 2.83 \\
Grain Density & 3.17 \\
& \\
Other Data: & $78 \mathrm{~cm}$ \\
Therm, cond. & \\
(mcal/cm-s. & 3.51
\end{tabular}

3.51

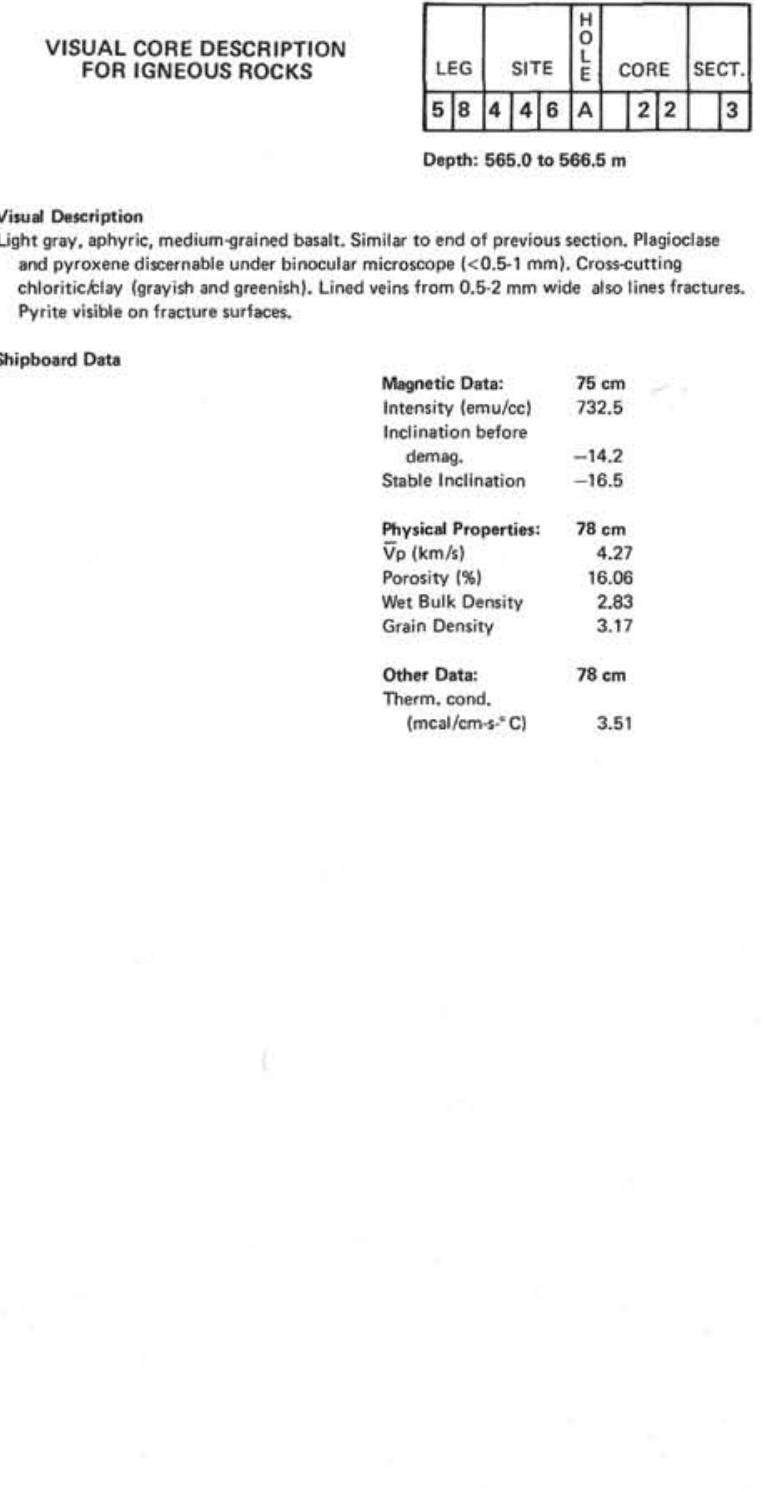

Light gray, medium- to fine-grained basalt, similar to previous section. Cross-cutting chloritic and pyrite lined fractures and veins.

Shipboard Data

\begin{tabular}{|c|c|}
\hline \multirow{3}{*}{$\begin{array}{l}\text { Magnetic Data: } \\
\text { Intensity (emu/cc) } \\
\text { Inclination before } \\
\text { demag. }\end{array}$} & $95 \mathrm{~cm}$ \\
\hline & 619.4 \\
\hline & -20.2 \\
\hline Stable Inclination & \\
\hline $\begin{array}{l}\text { Physical Properties: } \\
\bar{V}_{p}(\mathrm{~km} / \mathrm{s})\end{array}$ & $\begin{array}{r}95 \mathrm{~cm} \\
3.9\end{array}$ \\
\hline $\begin{array}{l}\text { ther Data: } \\
\text { Therm. cond. }\end{array}$ & \\
\hline
\end{tabular}

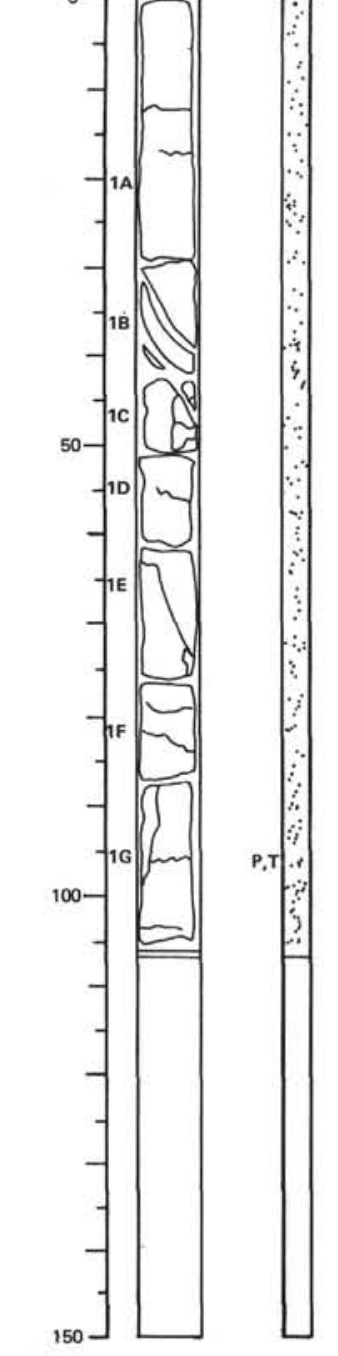




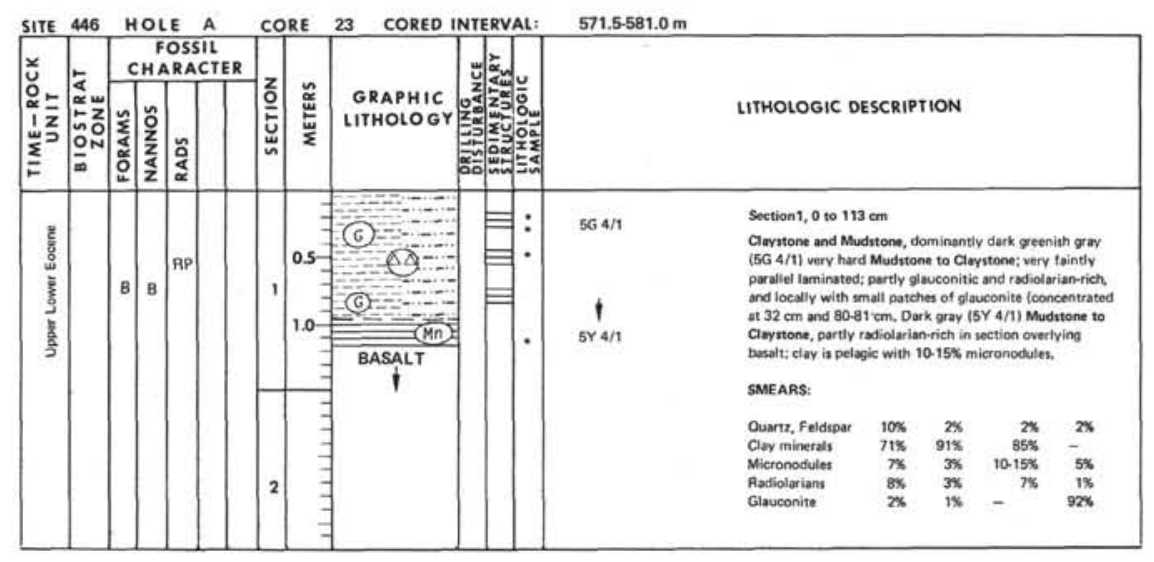



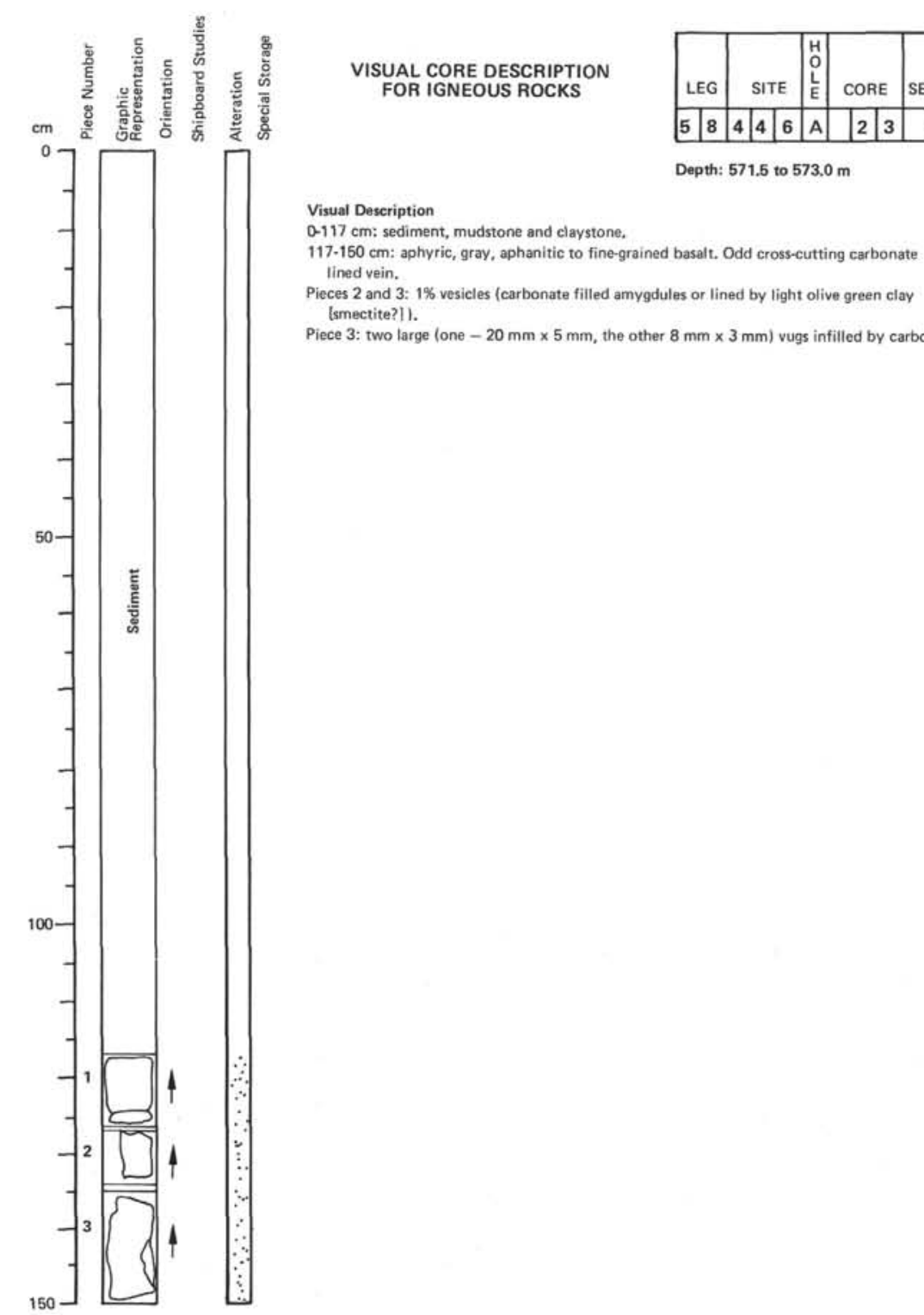

Depth: 571.5 to $573.0 \mathrm{~m}$

Visual Description

$117-150 \mathrm{~cm}$ : aphyric, gray, aphanitic to fine-grained basalt. Odd cross-cutting carbonate Pieces 2 and 3: $1 \%$ vesicles (carbonate filled amygdules or lined by light olive green clay

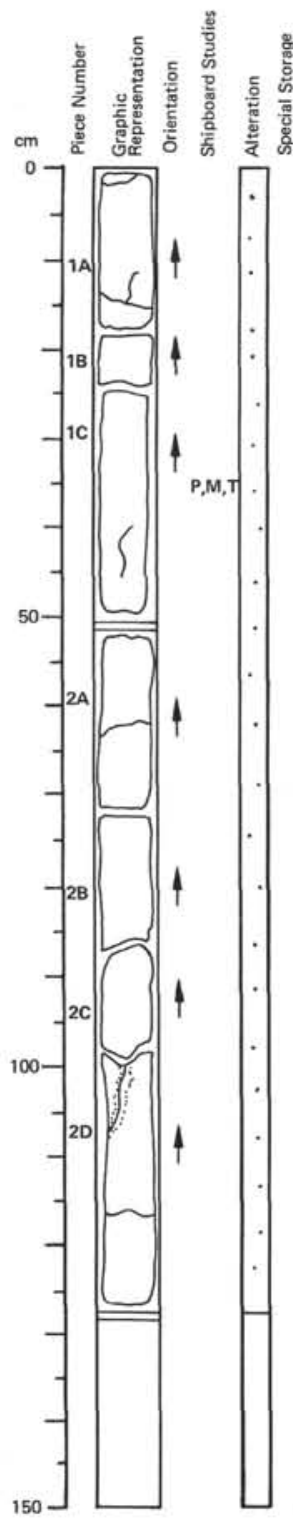

VISUAL CORE DESCRIPTION FOR IGNEOUS ROCKS

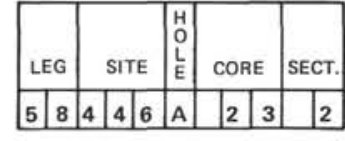
Depth: 573.0 to $574.3 m$

Visual Description

fine-grained basalt. Similar to previous section, Cross-cutting calcite or

Occasional vesicles, 0.5-1 mm, usually filled by carbonate or lined by light olive green clay (smectite).

Pieces 18 and 1C): large vug at least $25 \times 40 \mathrm{~mm}$ infilled by carbonate $84 \mathrm{~cm}$ (Piece 28): large ving outer surface to inner? $17 \times 10$.

$97.103 \mathrm{~cm}$ : chloritic vein with $2 \mathrm{~mm}$ wide alteration zone. Some other large carbonate vugs (from $5 \mathrm{~mm} \cdot 10 \mathrm{~mm}$ ).

Shipboard Data

$52 \mathrm{~cm}-2.040$

$\mathrm{SiO}_{2} \quad 52.17$

$\begin{array}{ll}\mathrm{Al}_{2} \mathrm{O}_{3} & 12.02 \\ \mathrm{Fe}_{2} \mathrm{O}_{3} & 1.42\end{array}$

$\begin{array}{ll}\mathrm{FeO} & 9.36 \\ \mathrm{MgO} & 8.34\end{array}$

$\begin{array}{ll}\mathrm{MgO} & 8.34 \\ \mathrm{CaO} & 8.82\end{array}$

$\begin{array}{ll}\mathrm{Na}_{2} \mathrm{O} & 2.66 \\ \mathrm{~K}_{2} \mathrm{O} & 0.83\end{array}$

$\begin{array}{ll}\mathrm{K}_{2} \mathrm{O} & 0.83 \\ \mathrm{TiO}_{2} & 3.31\end{array}$

$\begin{array}{ll}\mathrm{P}_{2} \mathrm{O}_{5} & 0.42 \\ \mathrm{MnO}^{2} & 0.16\end{array}$

LOI

$\mathrm{H}_{2} \mathrm{O}^{+}$
$\mathrm{H}_{2} \mathrm{O}^{-}$

$\begin{array}{ll}\mathrm{Cr}_{2} & -\overline{\mathrm{C}} \\ \mathrm{Ni} & \end{array}$

$\begin{array}{lr}\mathrm{Ni} & 93.00 \\ \mathrm{Si} & 413.00\end{array}$

$\mathrm{Zr}-268.00$

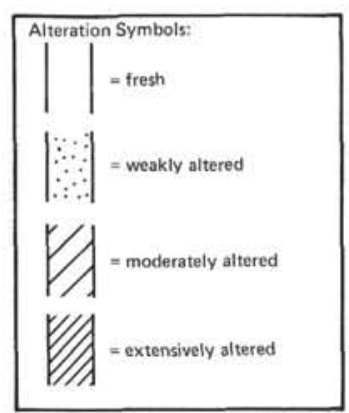

Stable Inclination $\quad-4.8$

Physical Properties: $\quad 43 \mathrm{~cm}$
$\bar{V} p(\mathrm{~km} / \mathrm{s})$

Other Data: $\quad 43 \mathrm{~cm}$

(mcal/cms. ${ }^{\circ}$ ) $\quad 4.11$ 

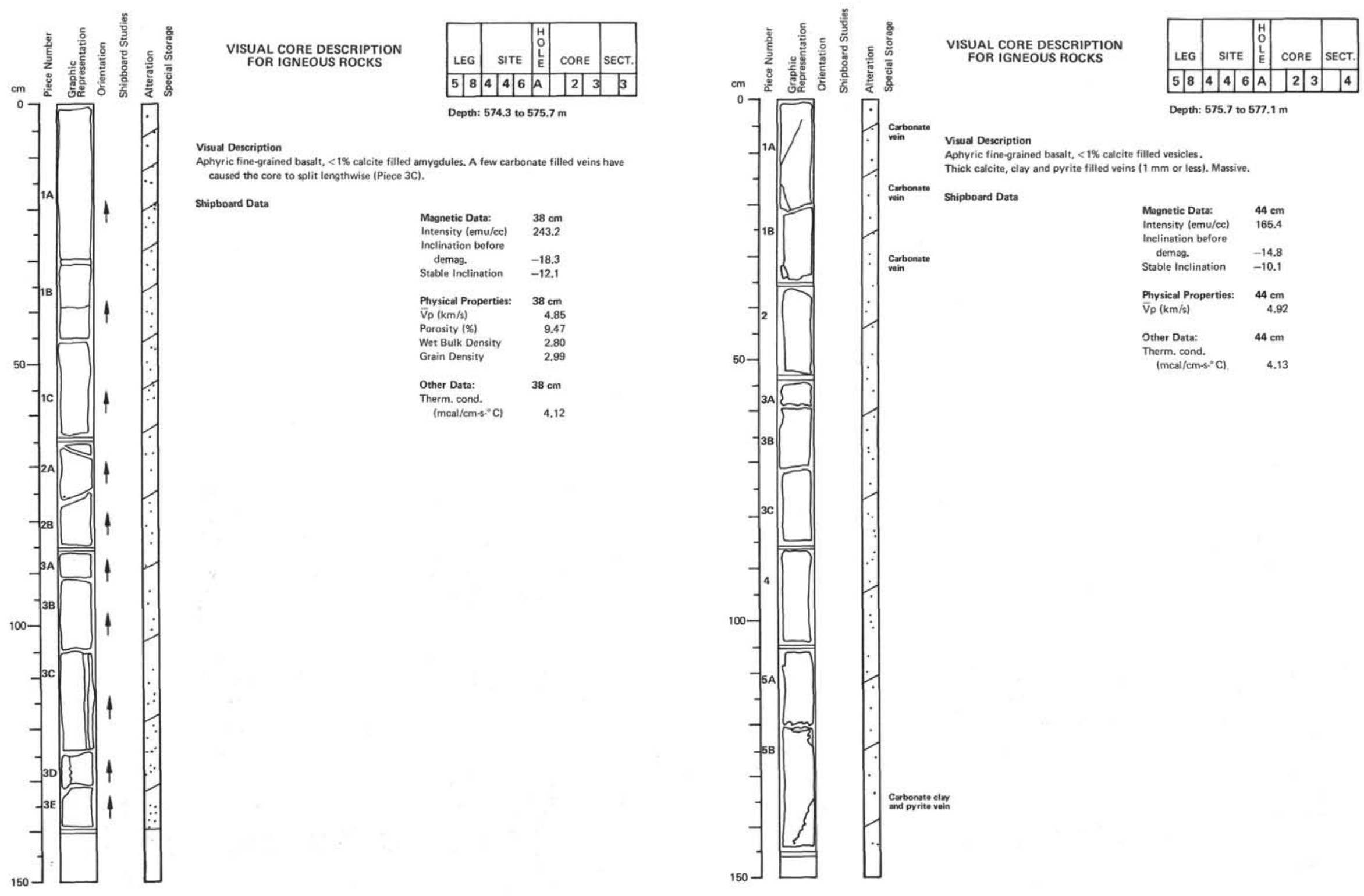

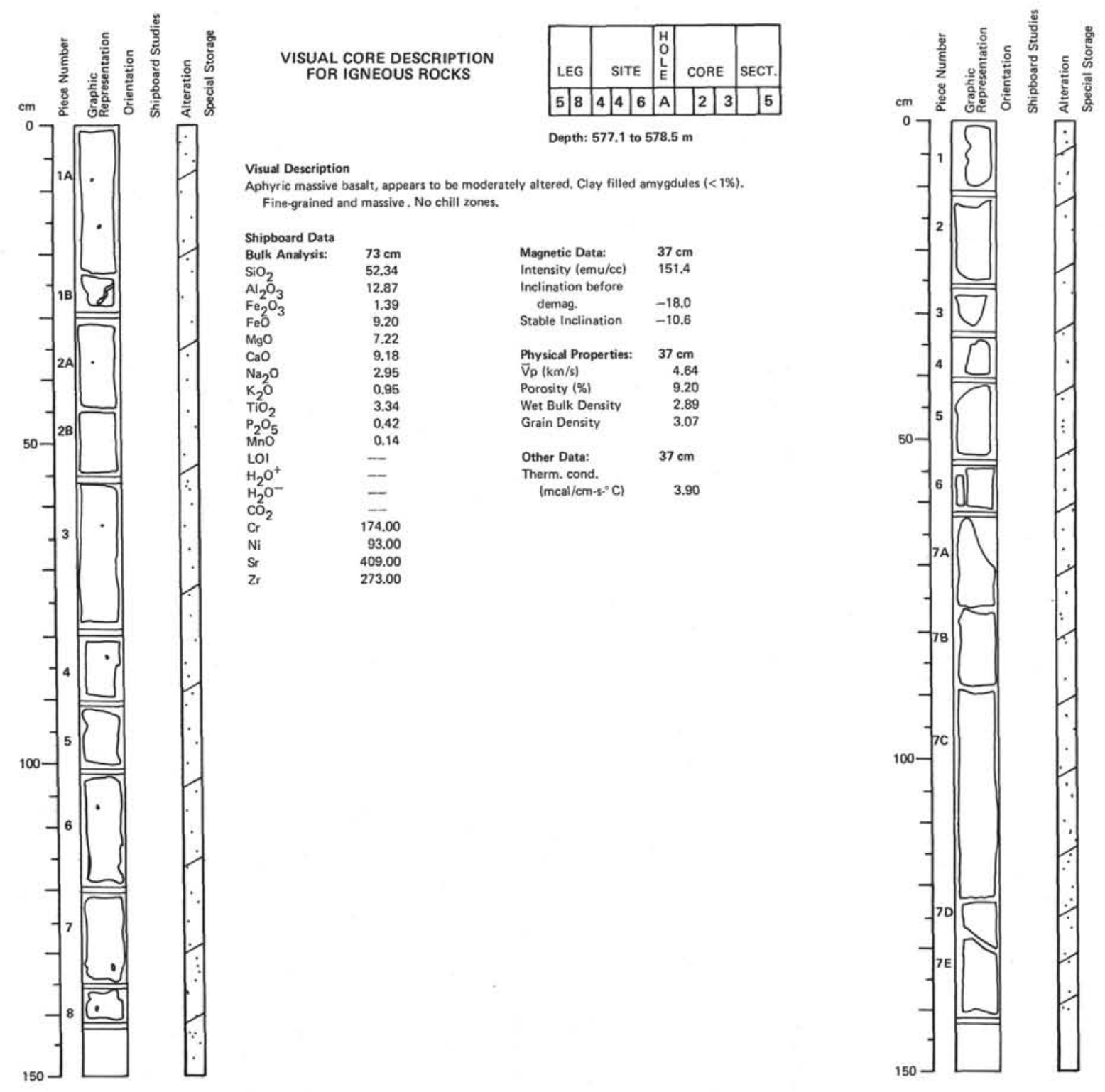

VISUAL CORE DESCRIPTION

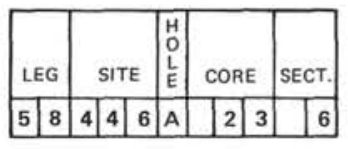

Visual Description

Basalt (?) massive, aphyric. Grain amount indicates that plagioclase is around $\mathrm{An}_{55}-\mathrm{An}_{65}$ : however quartz is present. The rock appears to be quite leucocratic compared to mou
basalts, but there appears to be no break between it and the more basaltic appearing material above in Section 1 through 5 . Mafics present in grain mount but lack cleavoge
mats and could be epidote, therefore this may be simply a highly altered basalt. Final determination awaits thin sections. Vesicles $<1 \%$, virtually absent.

Shipboard Data

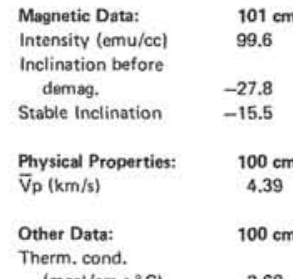

(mcal $/ \mathrm{cm} \cdot \mathrm{s}^{\circ} \mathrm{Cl}$ 


\begin{tabular}{|c|c|c|c|c|c|c|c|c|c|c|c|c|}
\hline \multirow{2}{*}{\multicolumn{2}{|c|}{ 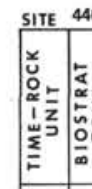 }} & \multicolumn{3}{|c|}{$\begin{array}{l}\text { HOLE A } \\
\text { FOSSIL } \\
\text { CHARACTER }\end{array}$} & \multirow{2}{*}{\multicolumn{2}{|c|}{ | }} & \multirow{2}{*}{\multicolumn{2}{|c|}{ 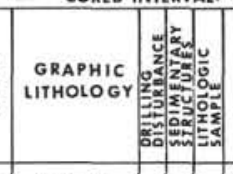 }} & \multirow{2}{*}{. } & \multirow{2}{*}{\multicolumn{3}{|c|}{ LITHOLOGIC DESCRIPIION }} \\
\hline & & & & & & & & & & & & \\
\hline \multirow{2}{*}{ 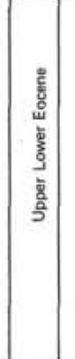 } & \multirow{2}{*}{\multicolumn{2}{|c|}{ B }} & \multirow{2}{*}{\multicolumn{2}{|c|}{$B$}} & \multirow{2}{*}{\multicolumn{2}{|c|}{$\int_{1.0}^{0.5}$}} & \multirow{2}{*}{\begin{tabular}{|c|} 
BASALT \\
BASALT \\
\\
(Fe) \\
Fe \\
$\begin{array}{c}\text { BASALT } \\
1\end{array}$ \\
Fe)
\end{tabular}} & \multirow{2}{*}{ 䀠 } & \multirow{2}{*}{$\begin{array}{l}\text { SB 4/11 } \\
10 Y 84 / 1 \\
6867 / 1 \\
\text { TOYR } 2 / 1 \\
\text { IOYR } 2 / 1\end{array}$} & \multicolumn{3}{|c|}{ 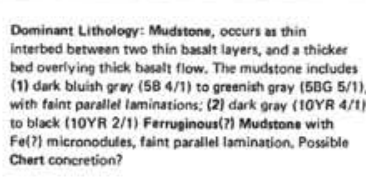 } \\
\hline & & & & & & & & & & $\begin{array}{l}\text { SMEARS: } \\
\text { Feidpar } \\
\text { Carpminerals } \\
\text { Gluconite } \\
\text { Mecronodulen }\end{array}$ & 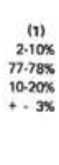 & 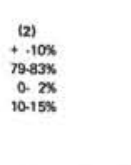 \\
\hline
\end{tabular}



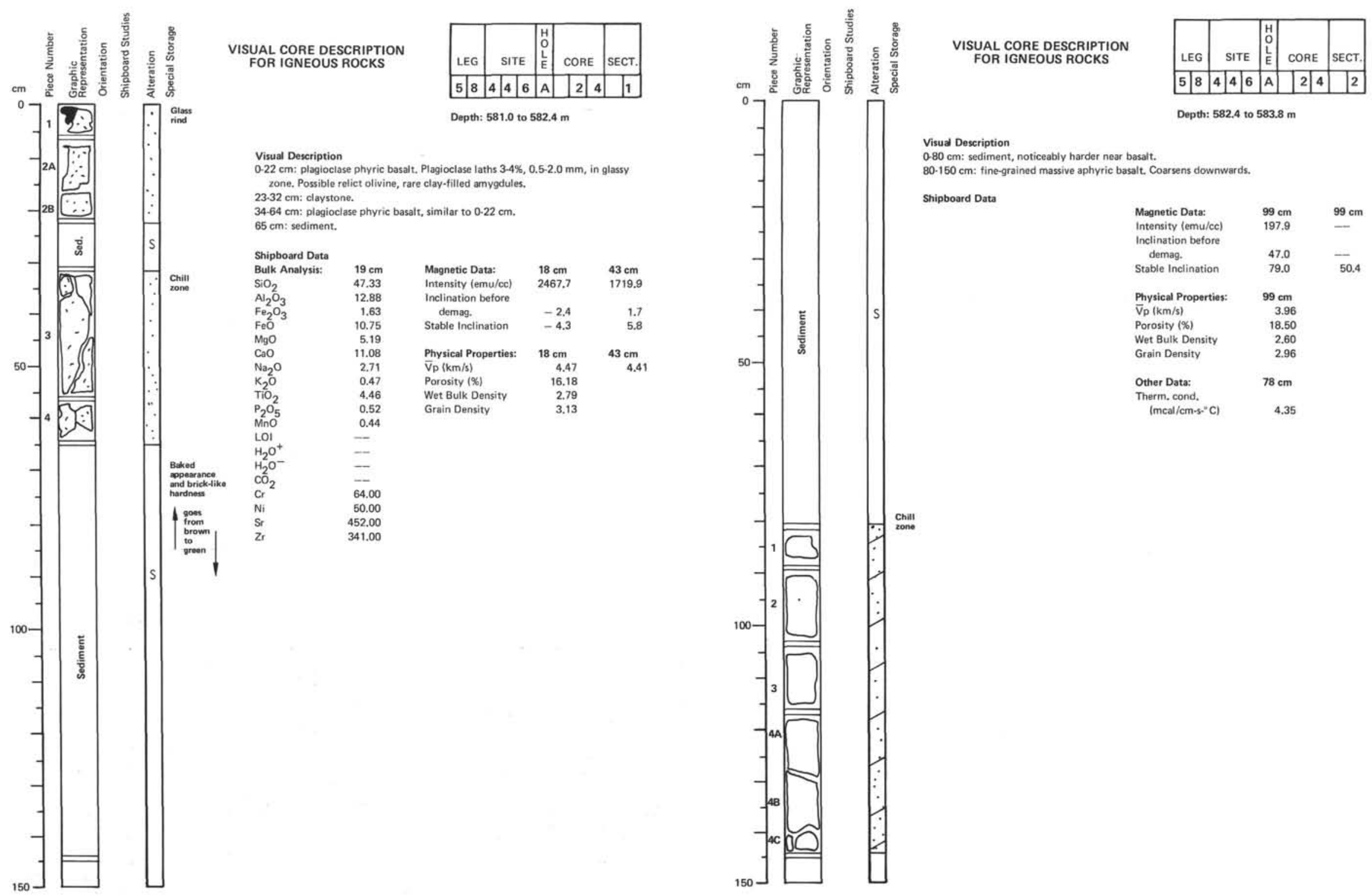


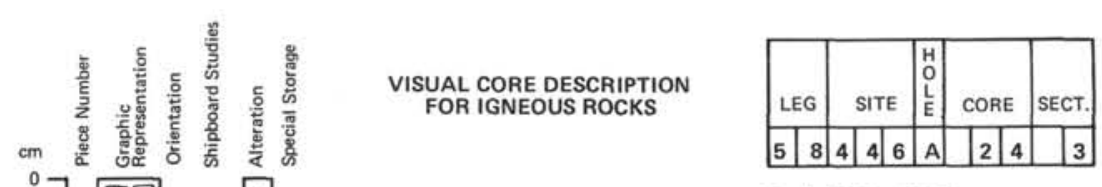

Amygdaloidal basalt. Aphyric, 0.30\% vesicles, note horizontal orientation of some chains of vesicles, $0.24 .4 \mathrm{~mm}$ calcite and clay initiling. Vesicles in Pieces 5, 6 , and 7 empty. The basalt is fine-grained and lightly altered.

Shipboard Data

$\begin{array}{lr}\text { Magnetic Data: } & 74 \mathrm{~cm} \\ \text { Intensict (emu/cc) } & 581.9 \\ \text { Inclination before } & \\ \quad \text { demag. } & 1.0 \\ \text { Stable Inclination } & -1.5 \\ \text { Plysical Properties: } & 74 \mathrm{~cm} \\ \text { Vp (km/s) } & 4.55 \\ \text { Porosity (\%) } & 13.73 \\ \text { Wet Bulk Density } & 2.75 \\ \text { Grain Density } & 3.03\end{array}$

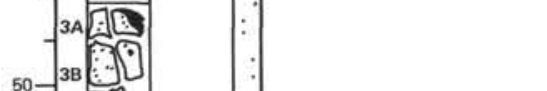

-3c $\because$ :
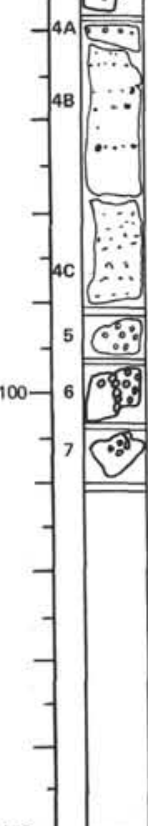

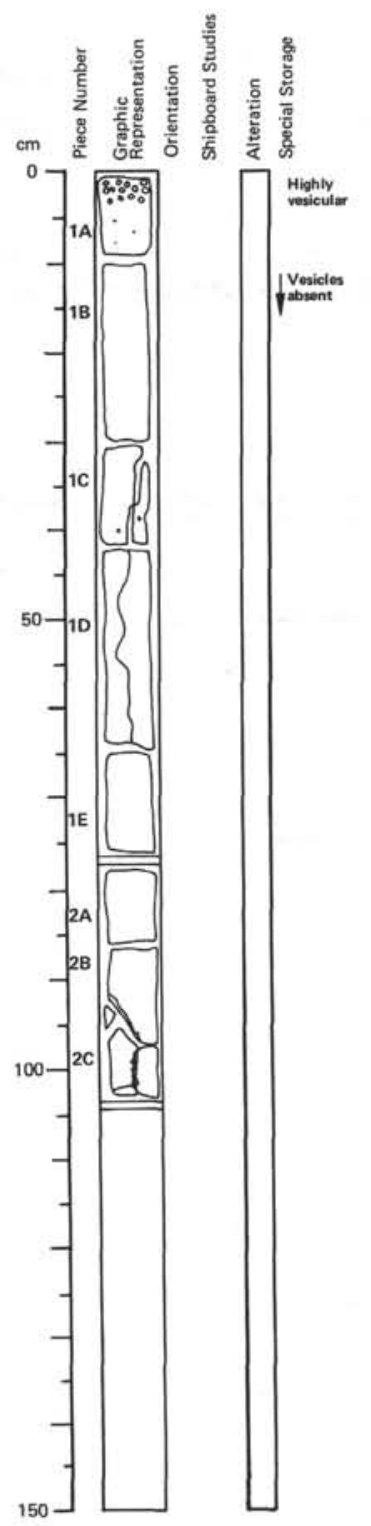

VISUAL CORE DESCRIPTION

FOR IGNEOUS ROCKS

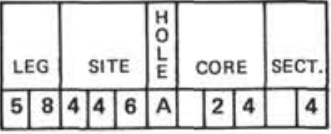

Depth: 584.9 to 586.0

Visual Description

alt Vesicles $20 \%$ in top $15 \mathrm{~cm}$, absent beneath. A few clay filled anygdules. Fine-grained up to Piece $2 \mathrm{C}$ which abruptly becomes medium-grained.

Shipboard Data

$\begin{array}{llll} & 73 \mathrm{~cm} & \text { Magnetic Data: } & 86 \mathrm{~cm} \\ \mathrm{SiO}_{2} & 49.51 & \text { Intensity (emu/cc) } & 222.3\end{array}$

$\mathrm{Al}_{2} \mathrm{O}_{3}$

$\begin{array}{lrrr} & 1.61 & \text { demag. } & -8.2 \\ \mathrm{FeO}^{2} & 10.60 & \text { Stable Inclination } & 2.5\end{array}$

$\begin{array}{lrl}\mathrm{MgO} & 6.67 & \text { Physical Properties: } \\ \mathrm{CaO} & 86.31 & \mathrm{~cm}\end{array}$

$\begin{array}{lll}\mathrm{Na}_{2} \mathrm{O} & 2.69 & \overline{\mathrm{V} p}(\mathrm{~km} / \mathrm{s}) \\ \mathrm{K}_{2} \mathrm{O} & 0.37 & \text { Porosits } \\ \mathrm{N} & & 3.11\end{array}$

$\mathrm{K}_{2} \mathrm{O}$

$\begin{array}{lll}3.11 & \text { Wet Bulk Density } & 2.89 \\ 0.40 & \text { Grain Density } & 3.02\end{array}$

4.99
6.16
2.89

$\mathrm{P}_{2} \mathrm{O}_{5}$

$\begin{array}{ll}\mathrm{H}_{2} \mathrm{O}^{+} & - \\ \mathrm{H}_{2} \mathrm{O}^{-} & - \\ \mathrm{CO}_{2} & -\end{array}$

$\begin{array}{ll}\mathrm{Cr}^{2} & 83.00 \\ \mathrm{Ni} & 53.00 \\ \mathrm{Ni} & 45.00\end{array}$

St $\quad 415.00$ 


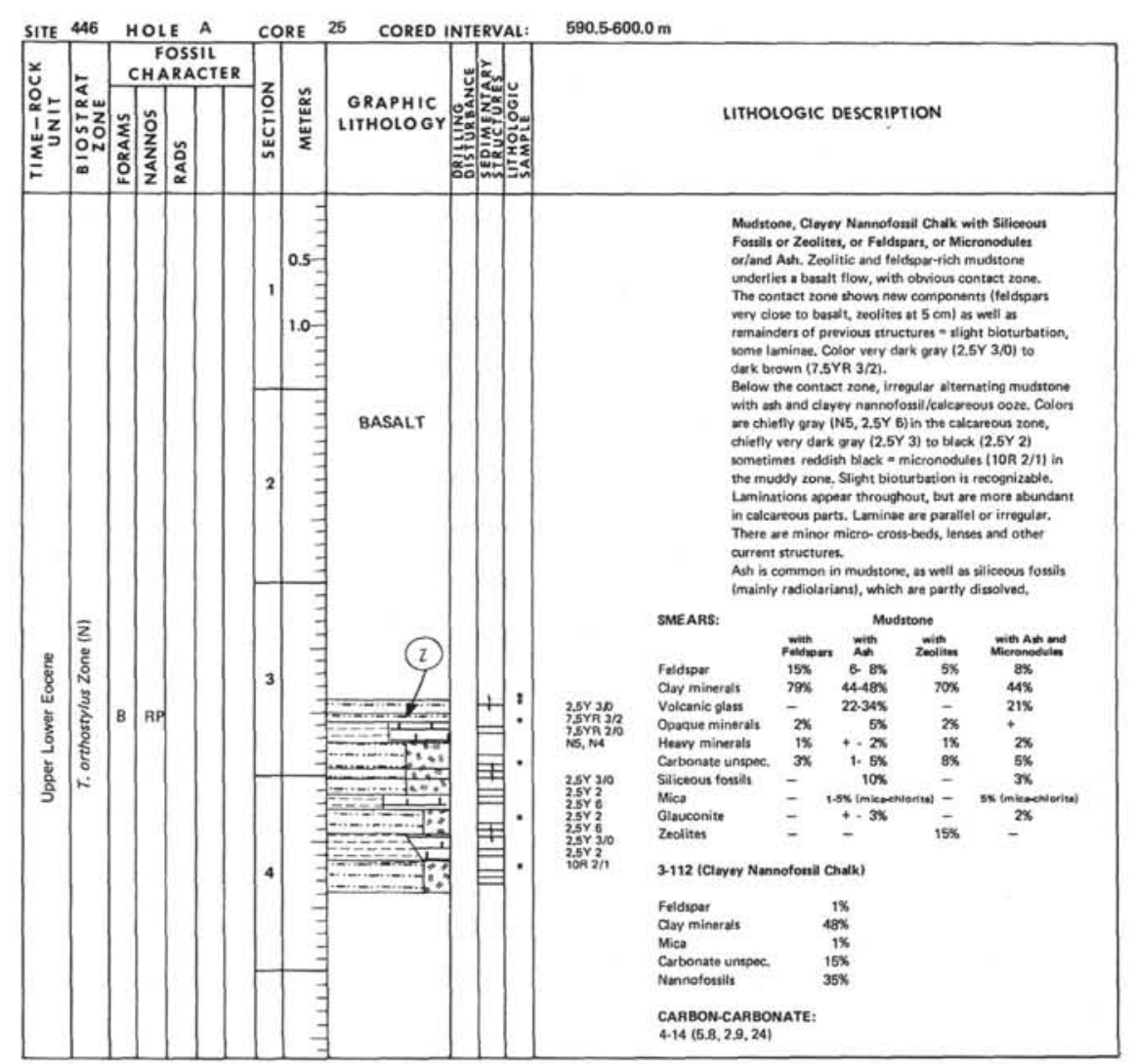



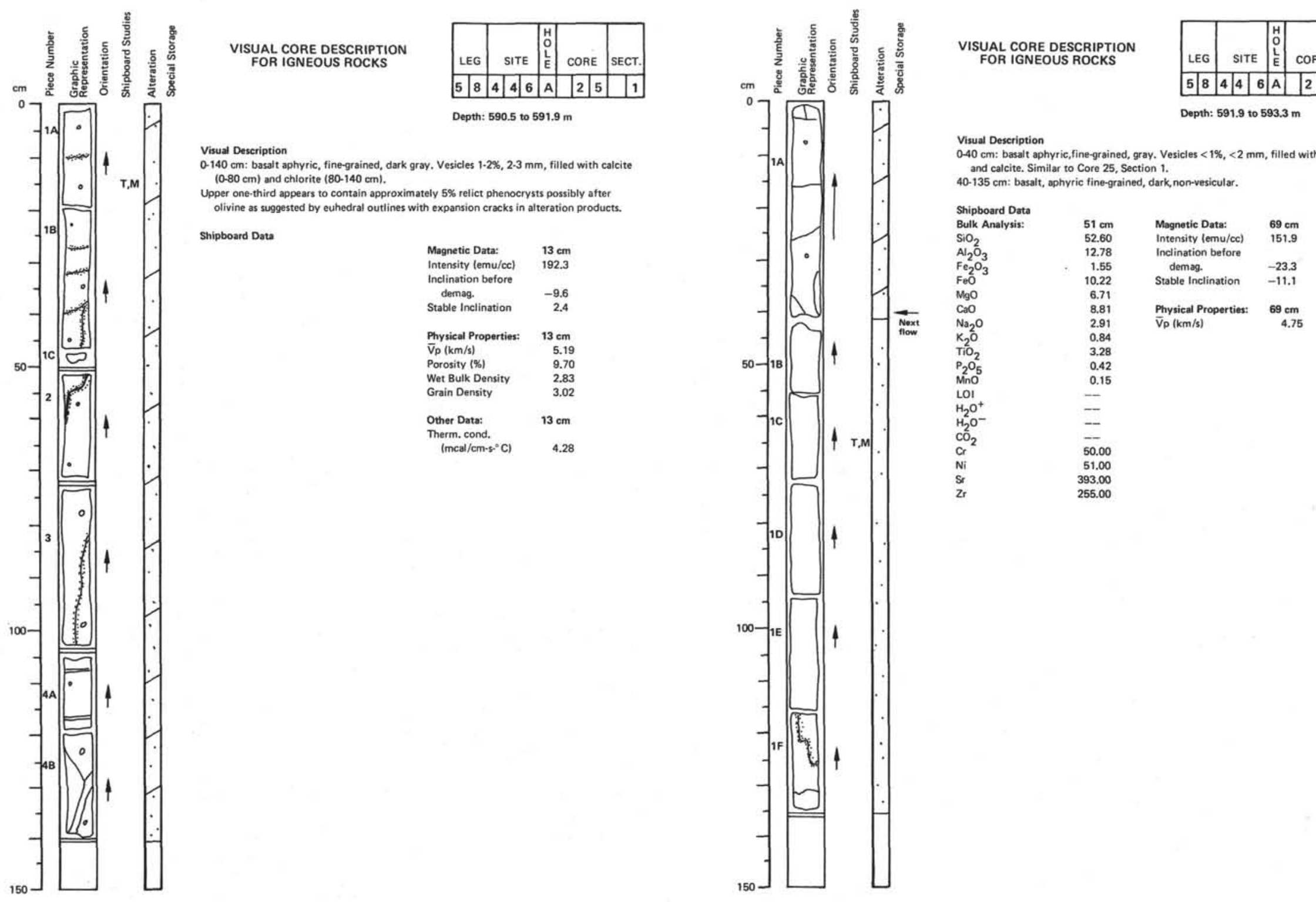


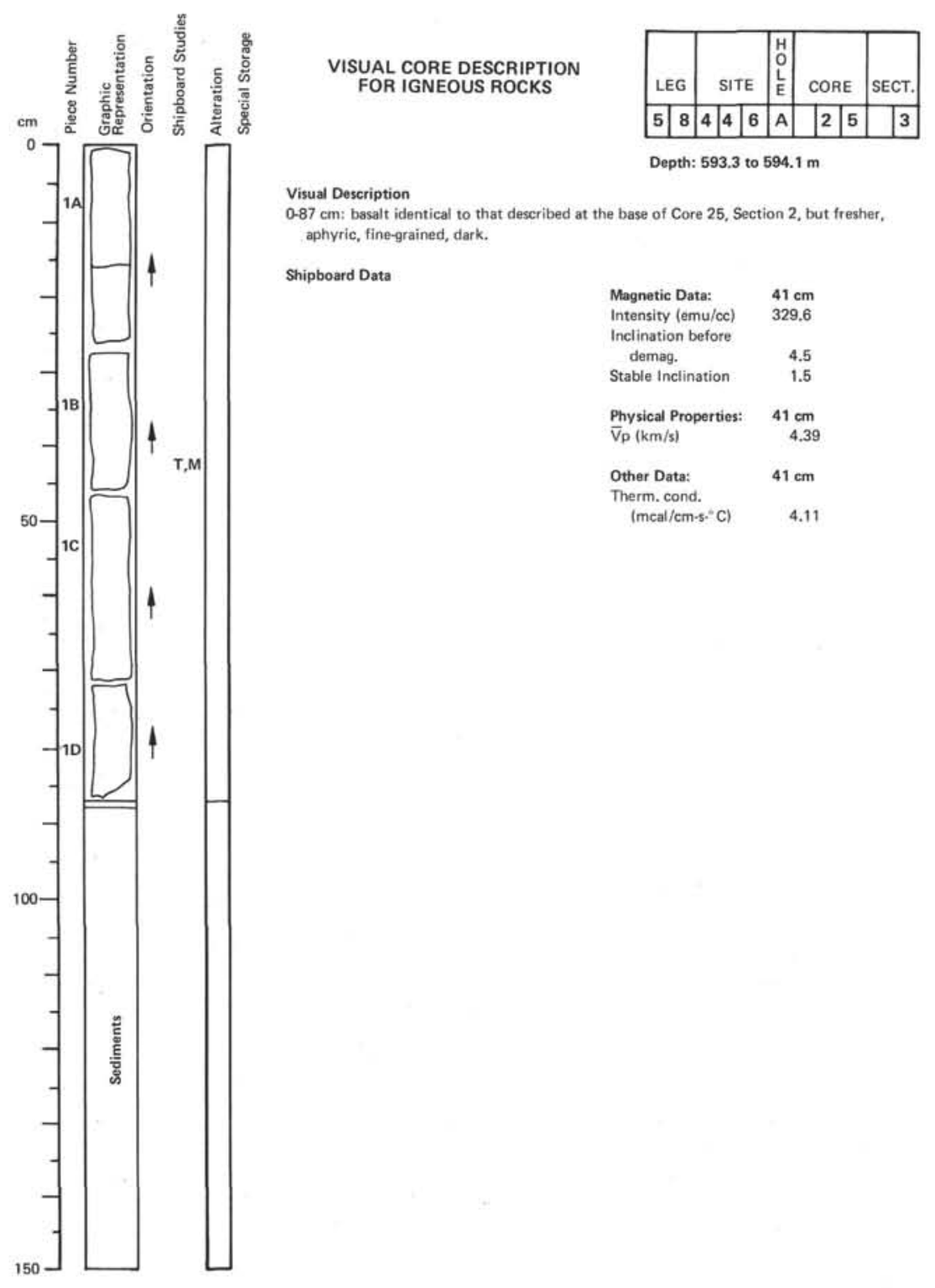




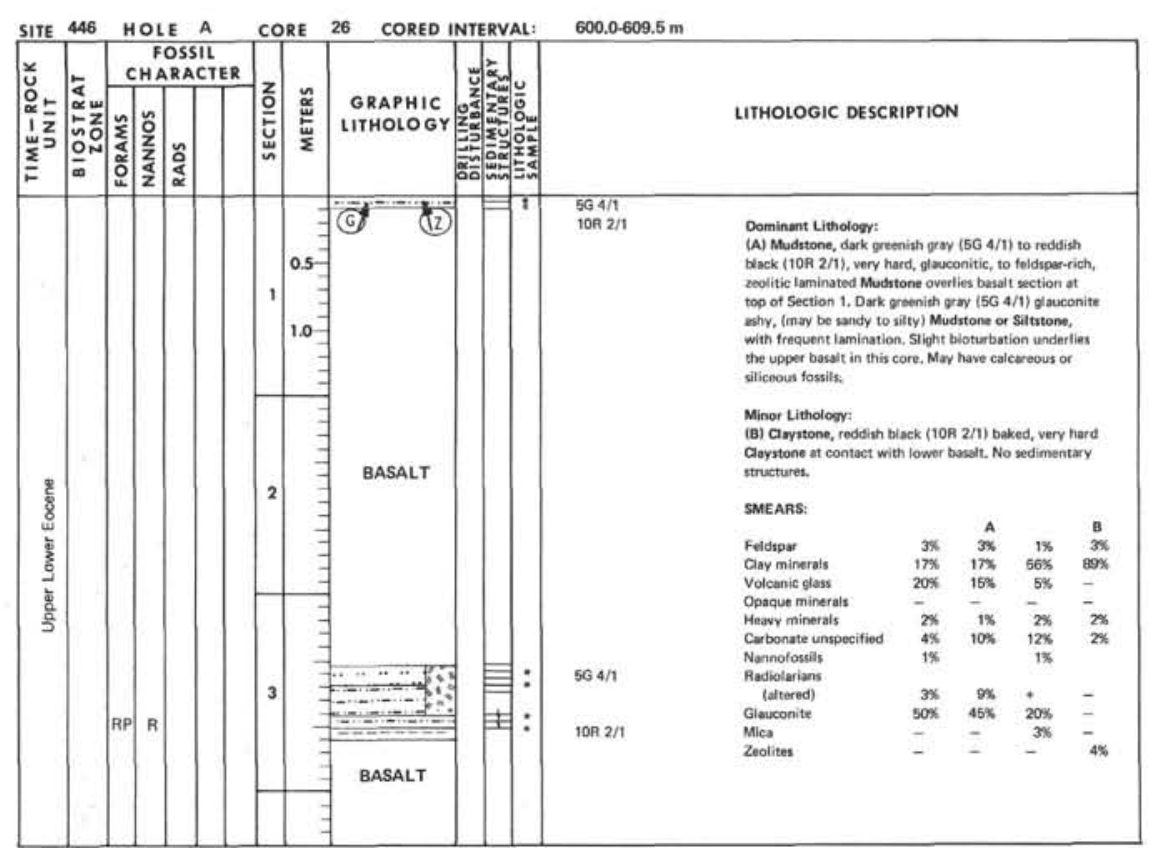




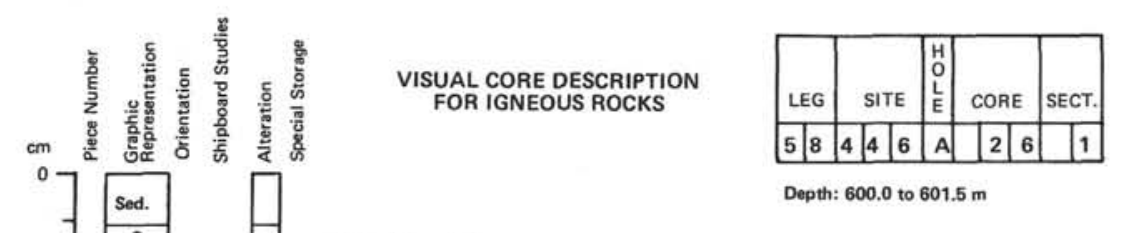

Visual Description

aphyric, fine-grained, gray, vesicular.

$\mathrm{mm}$, filled with calcite and chlorite.

Shipboard Data
Bulk Analysis: $\quad 33 \mathrm{~cm}$

$\begin{array}{ll} & \\ \mathrm{SiO}_{2} & 48.69 \\ \mathrm{Al}_{2} \mathrm{O}_{3} & 13.05\end{array}$

$\begin{array}{lr}\mathrm{Al}_{2} \mathrm{O}_{3} & 13.05 \\ \mathrm{Fe}_{2} \mathrm{O}_{3} & 1.44 \\ \mathrm{FeO}_{3} & \end{array}$

$\begin{array}{lr} & 9.54 \\ \mathrm{FeO} & 6.89 \\ \mathrm{MgO} & 10.87 \\ \mathrm{CoO} & 2.80 \\ \mathrm{Na}_{2} \mathrm{O} & 2.80\end{array}$

$\begin{array}{ll}\mathrm{K}_{2} \mathrm{O} & 0.83 \\ \mathrm{TO}_{2} & 3.41 \\ \mathrm{P}_{2} \mathrm{O}_{5} & 0.40 \\ \mathrm{MnO} & 0.24\end{array}$

LO

$\mathrm{H}_{2} \mathrm{O}^{+}$
$\mathrm{H}_{2} \mathrm{O}^{-}$

$\begin{array}{ll}\mathrm{C}_{2} & - \\ \mathrm{CO}_{2} & - \\ \mathrm{CO}_{2} & 169.00 \\ \mathrm{Ni} & 88.00 \\ \mathrm{Ni} & 423.00\end{array}$

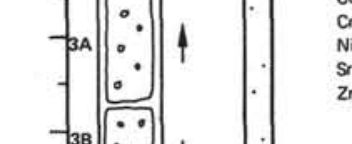

423.00
243.00

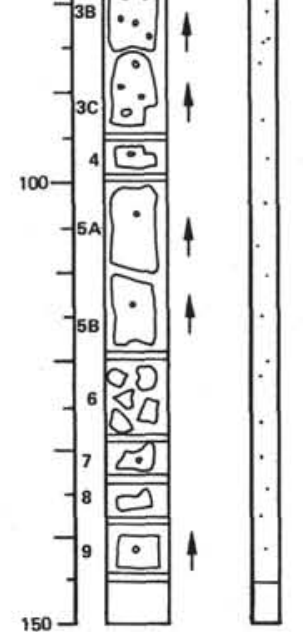

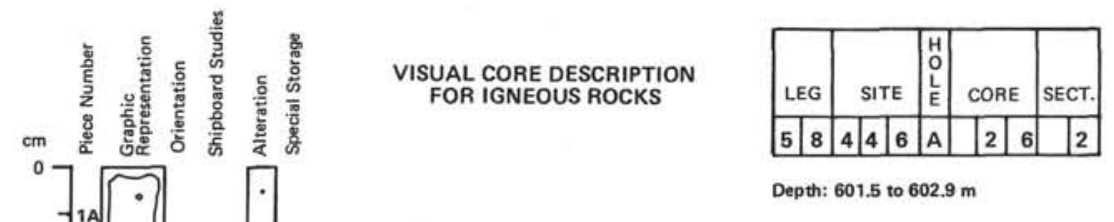

Visual Description

for Core 26, Section 1, fresher. Vesicles $<1 \%$,

$<1 \mathrm{~mm}$, filled with chlorite. Vein with calcite and chlorite. 

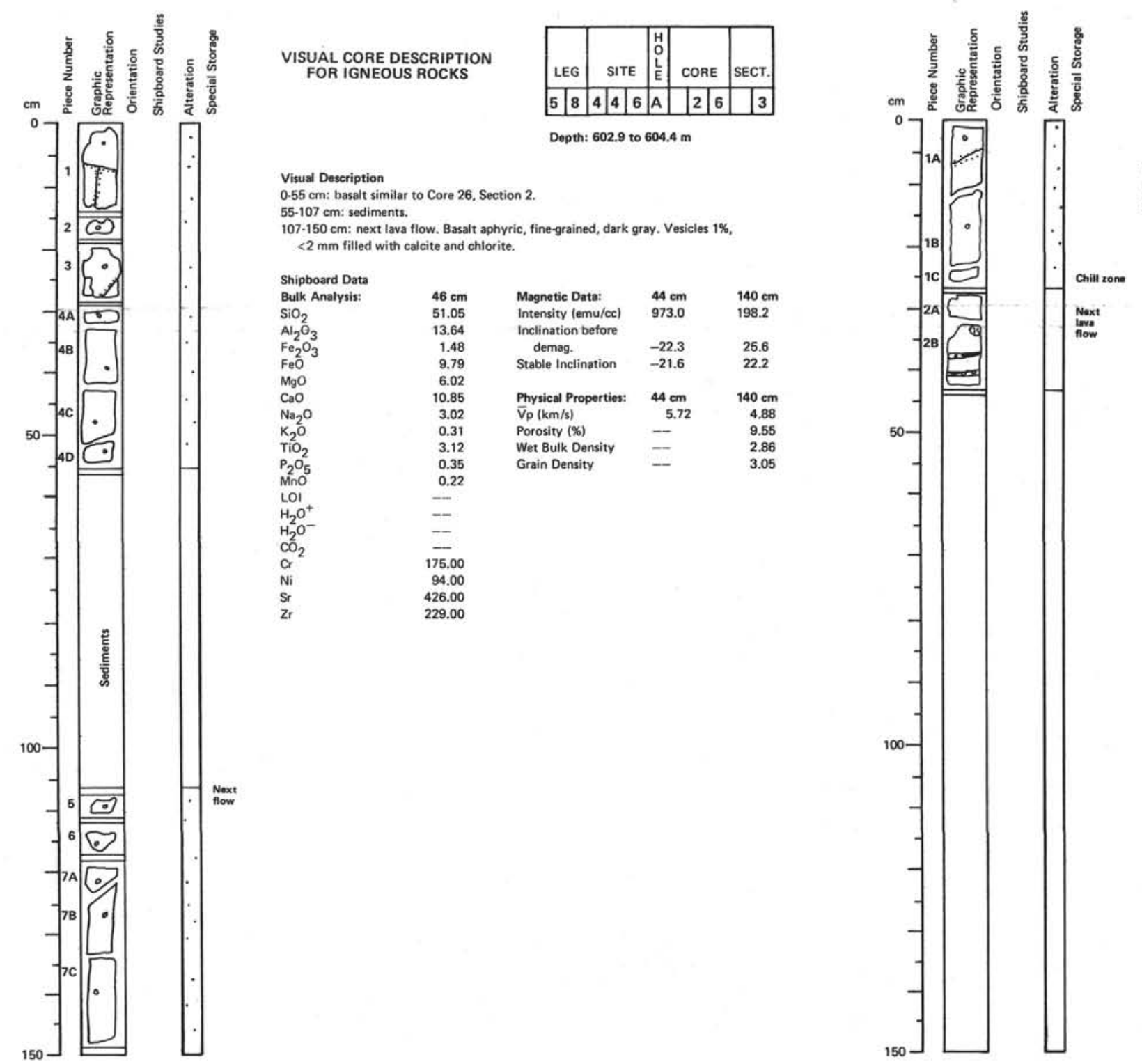

VISUAL CORE DESCRIPTION
FOR IGNEOUS ROCKS

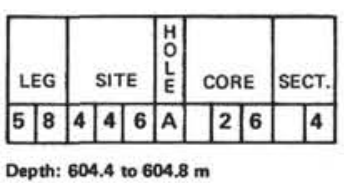

Visual Description

$0.27 \mathrm{~cm}$ : basalt identical to that described at the base of Core 26, Section 3 . aphyric, fine-grained (to aphanitic), dark, Vein with calcite. 


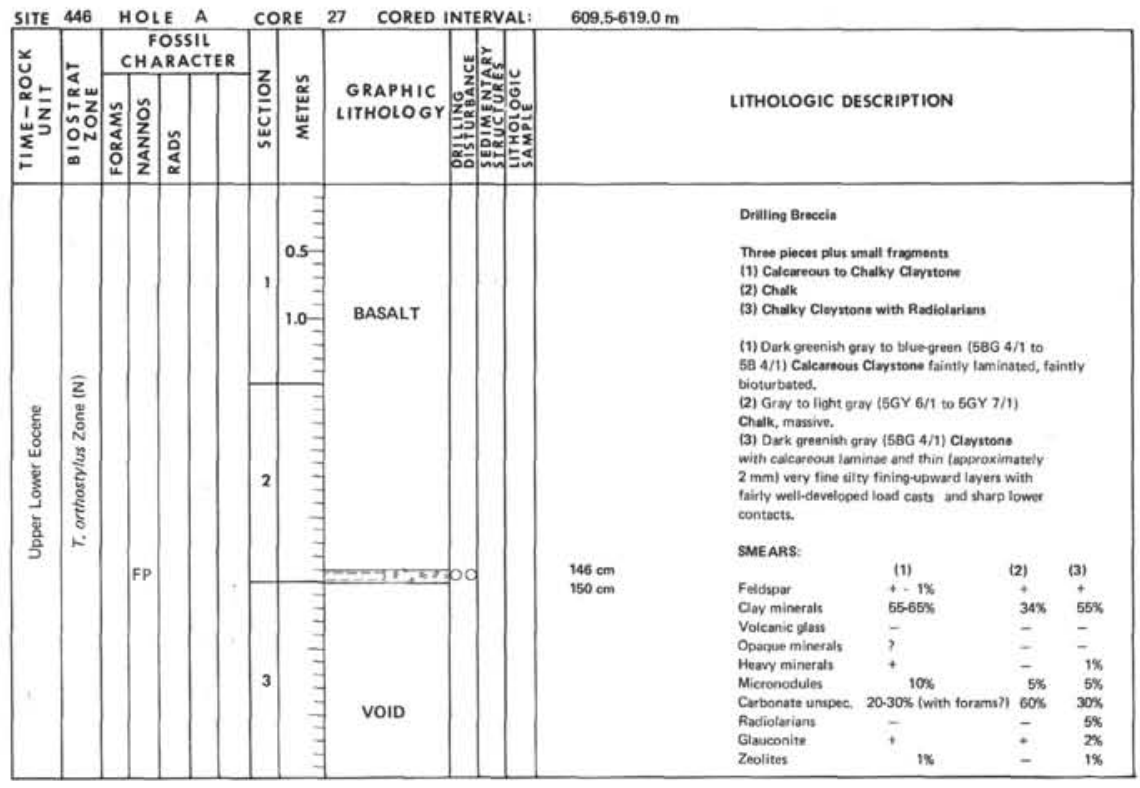



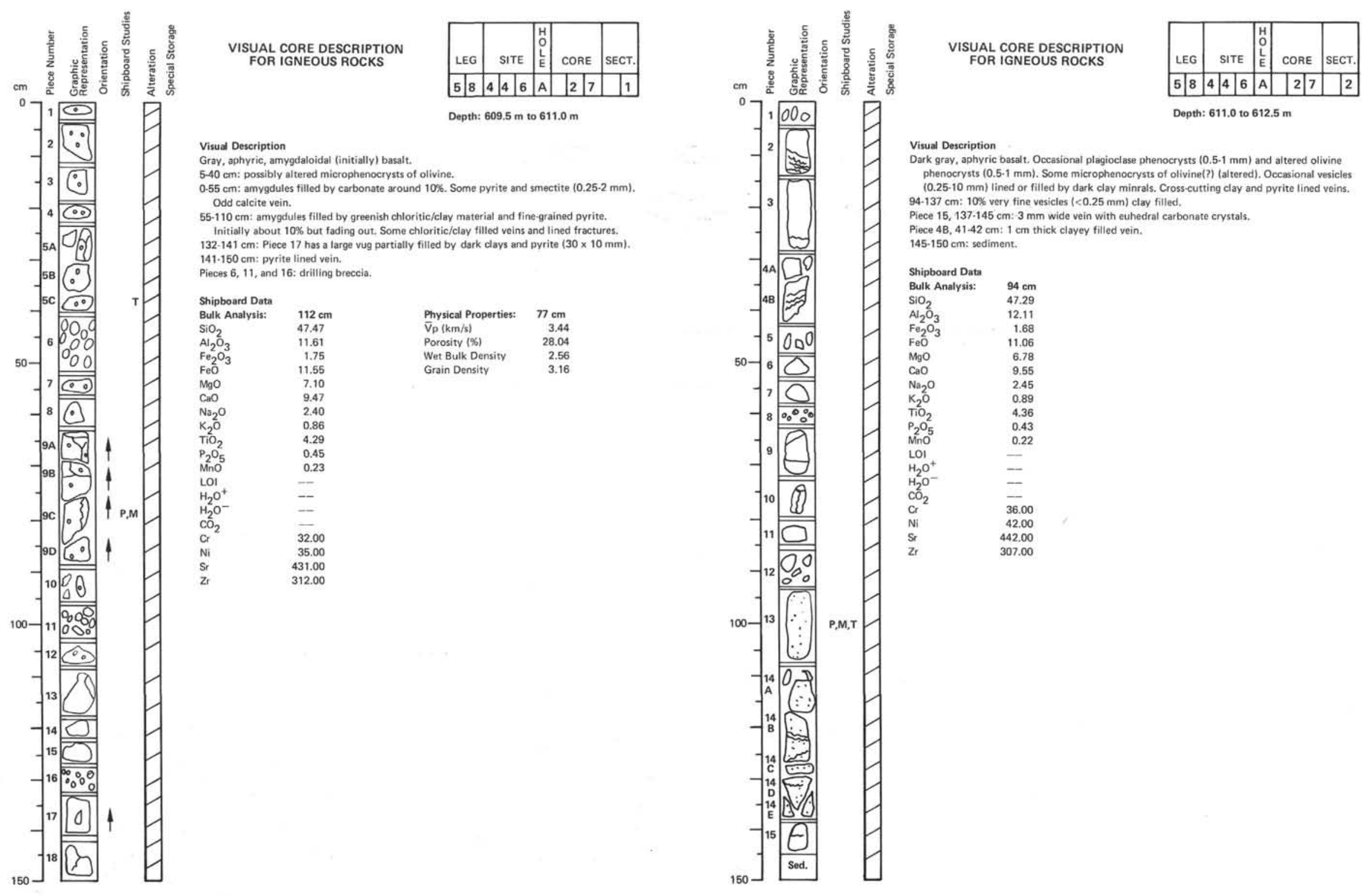


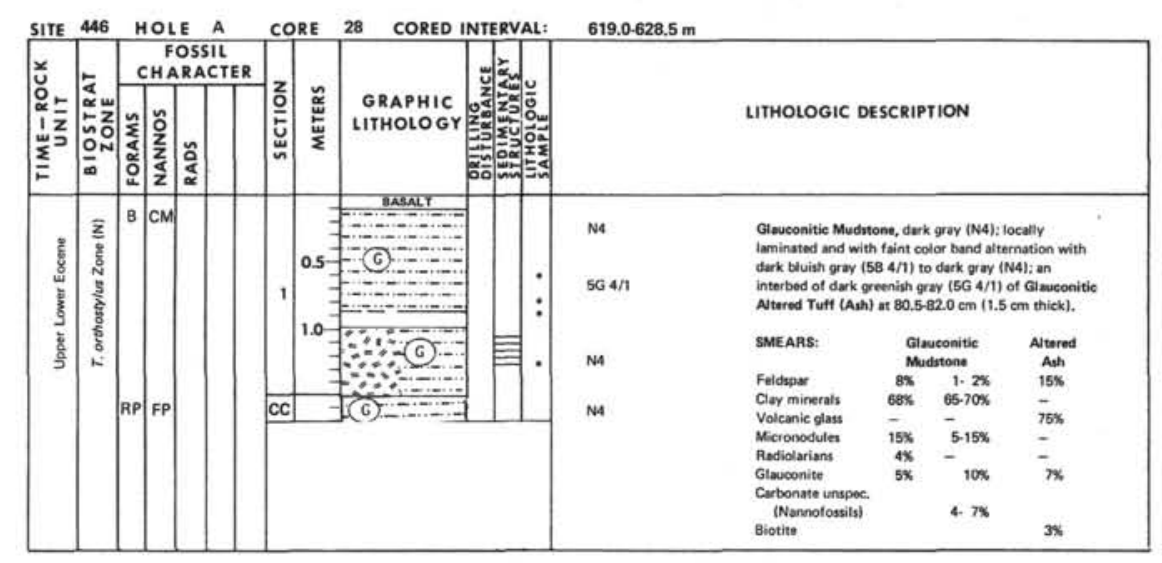




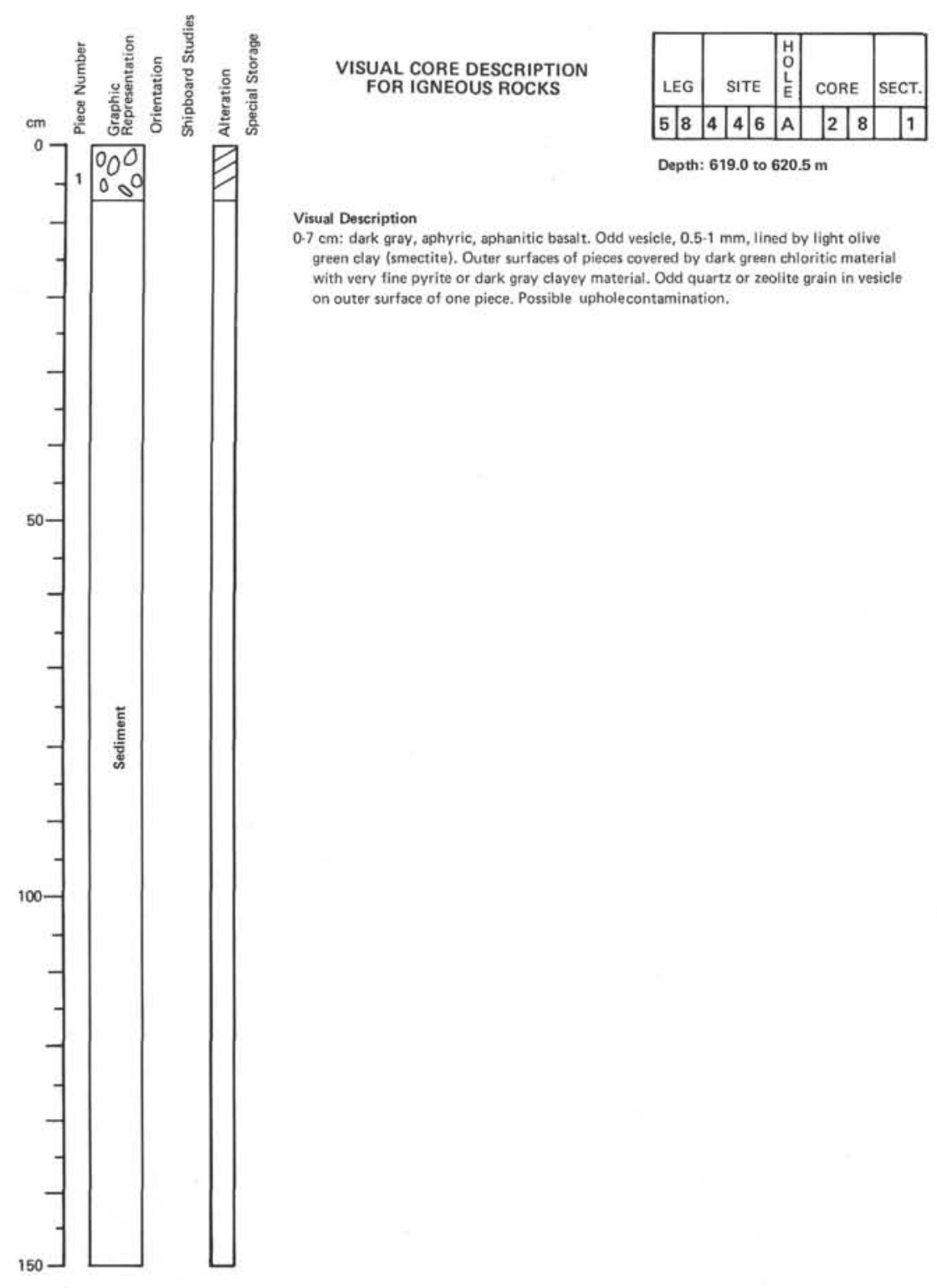


Site 446

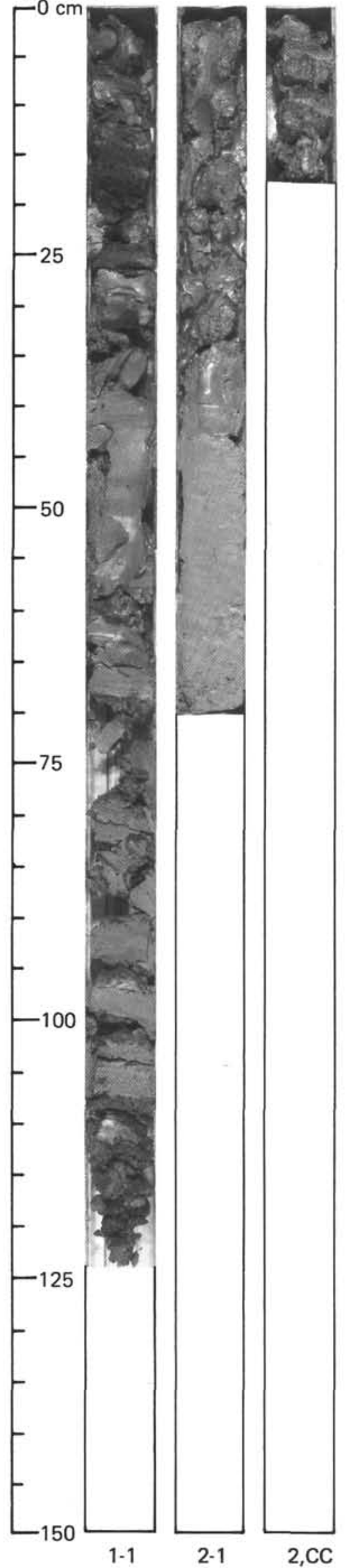

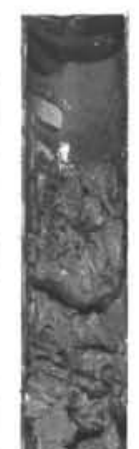
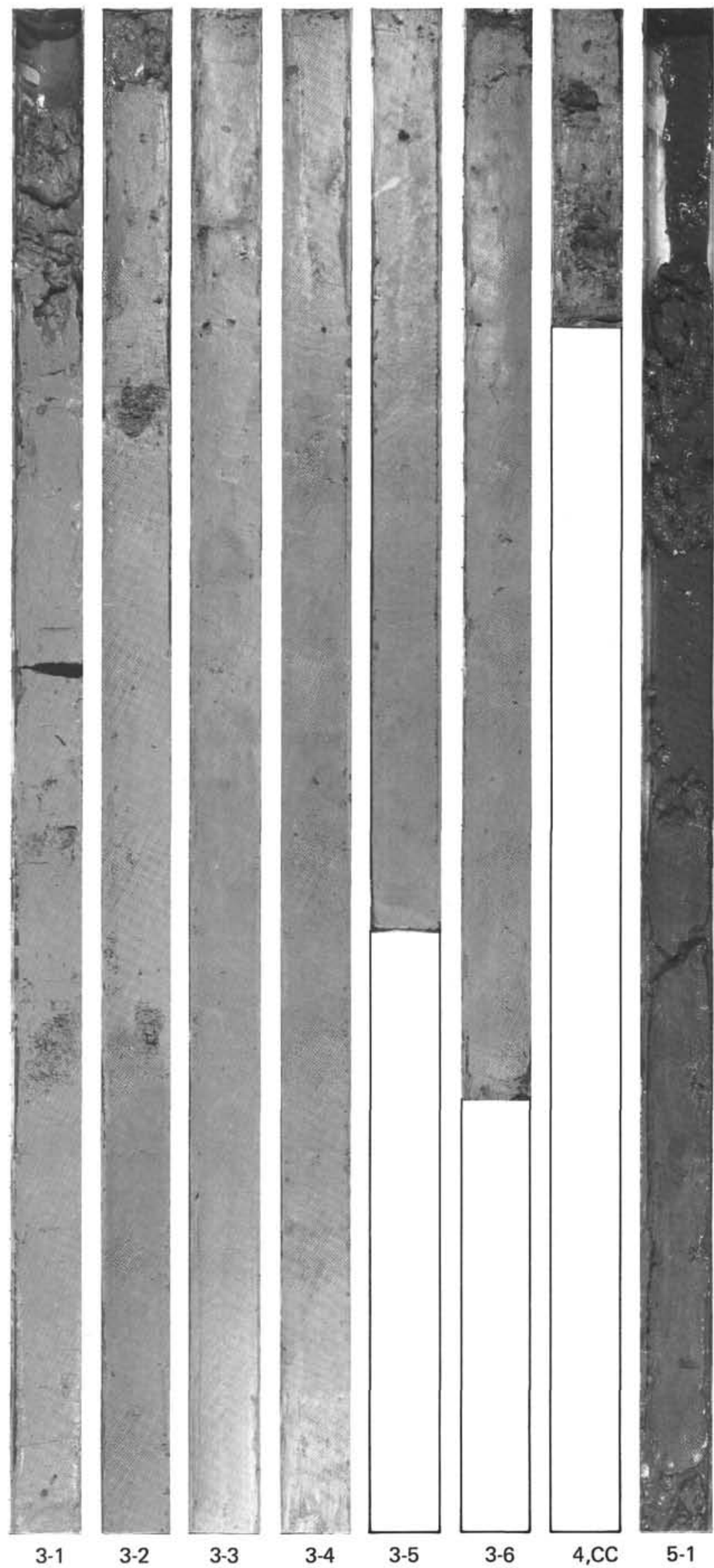
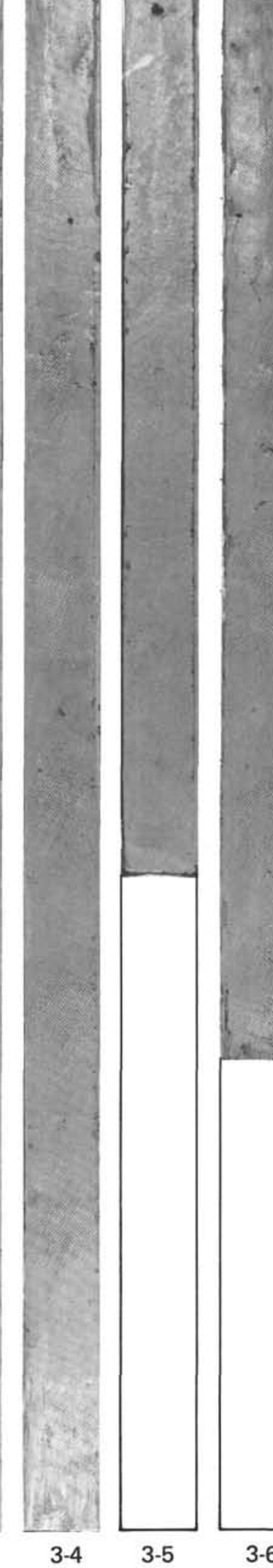

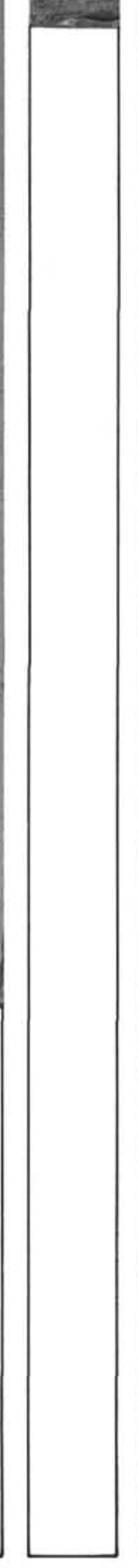

$4, \mathrm{CC}$
?

s.
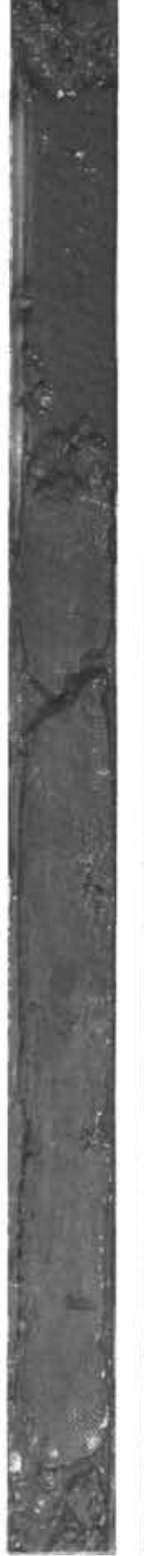

5-1
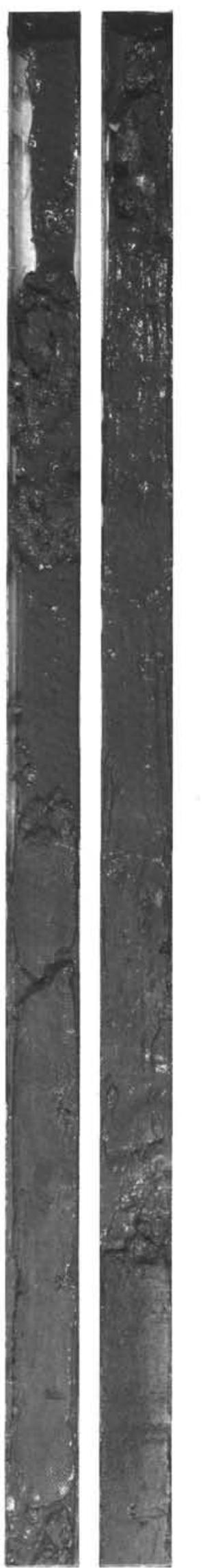
Site 446

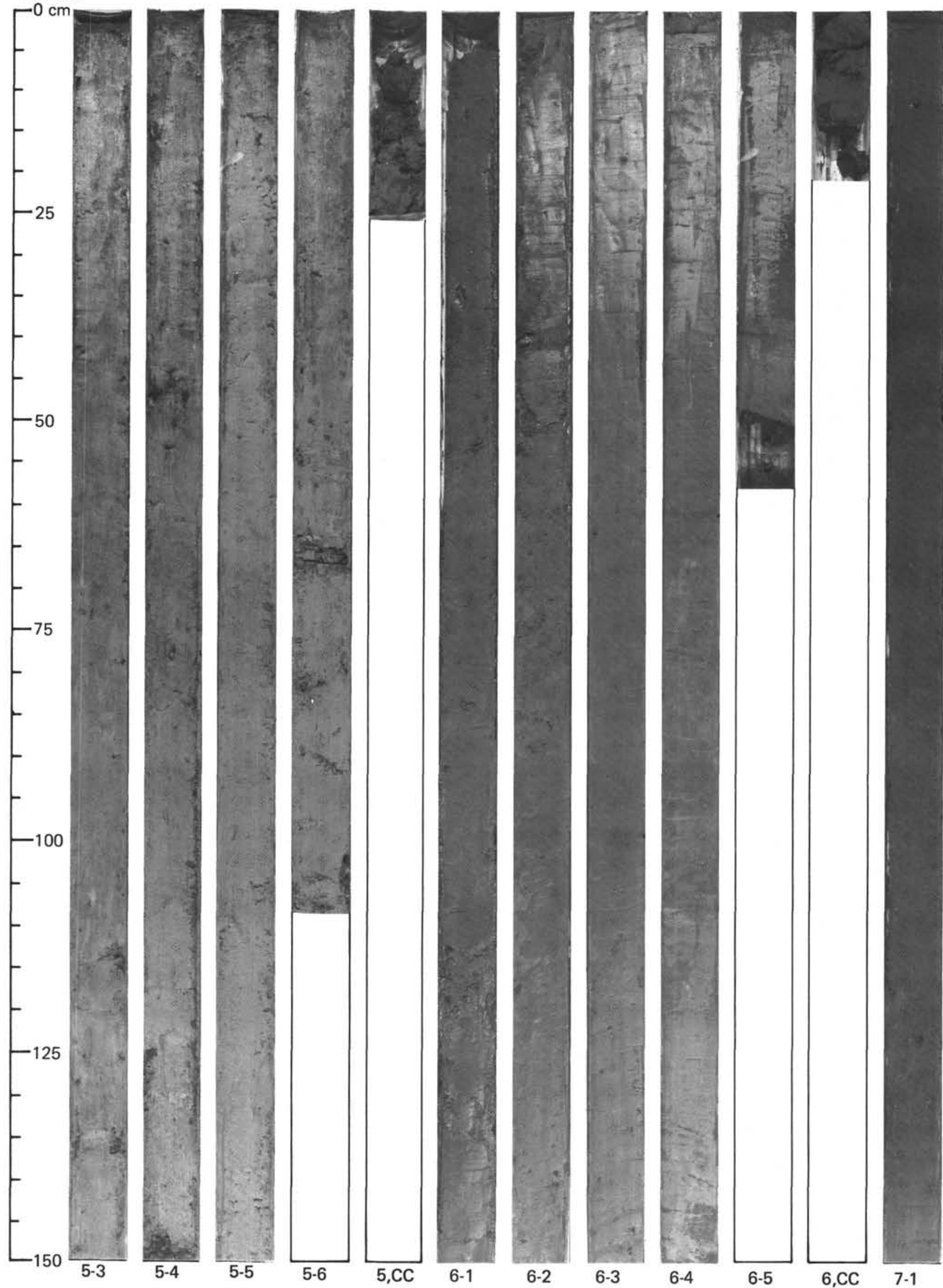




\section{Site 446}

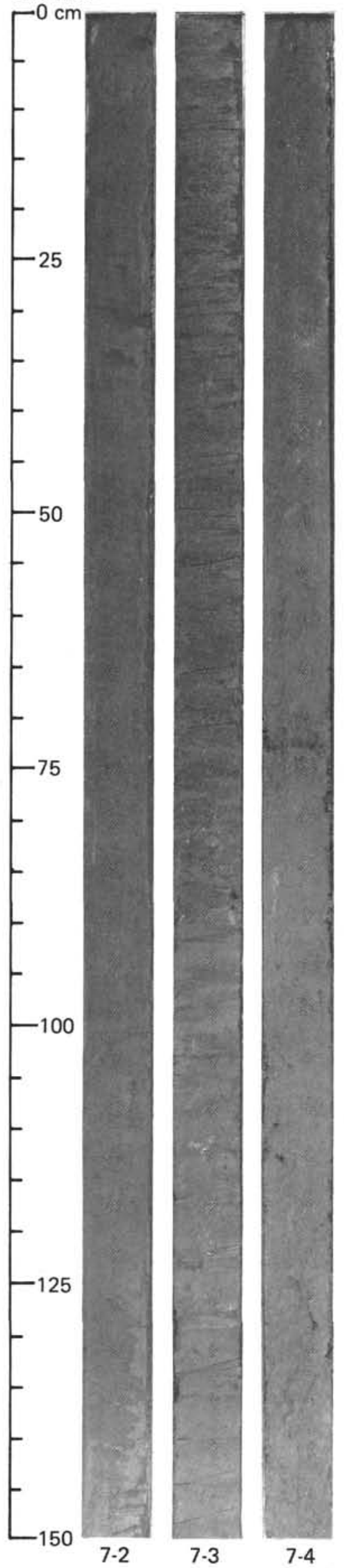

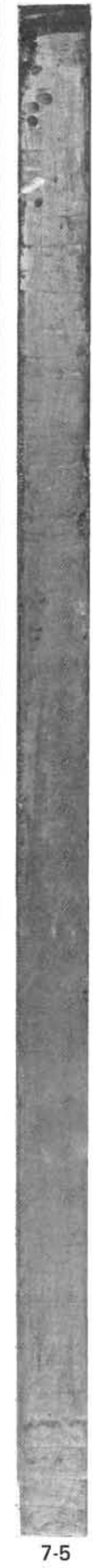

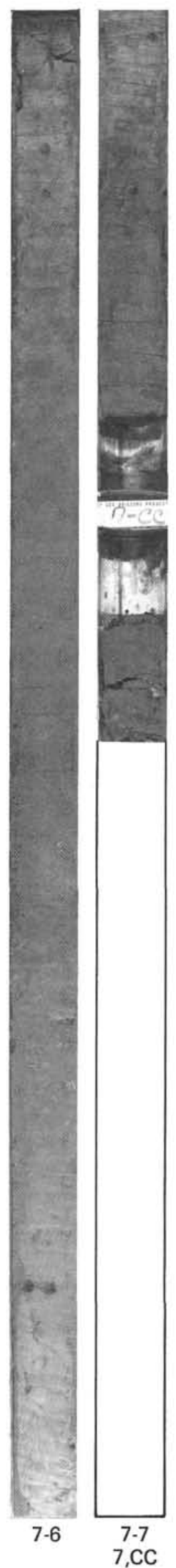

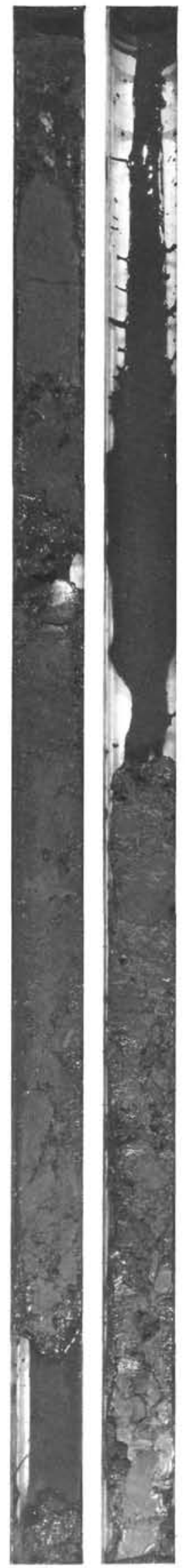
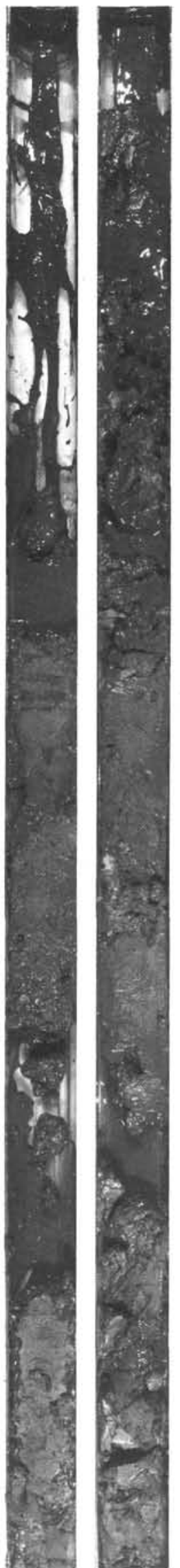

$8-4$
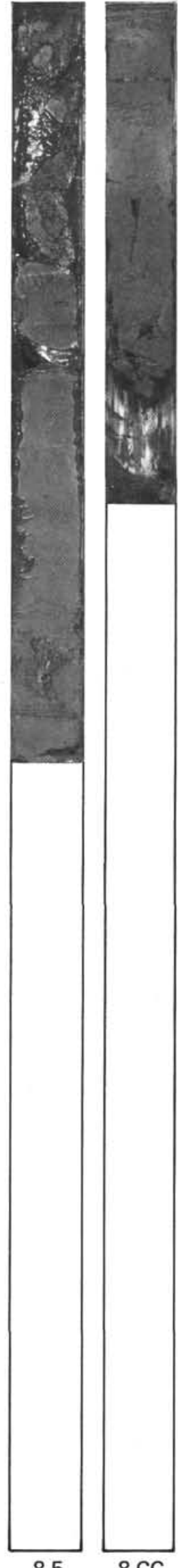
Site 446

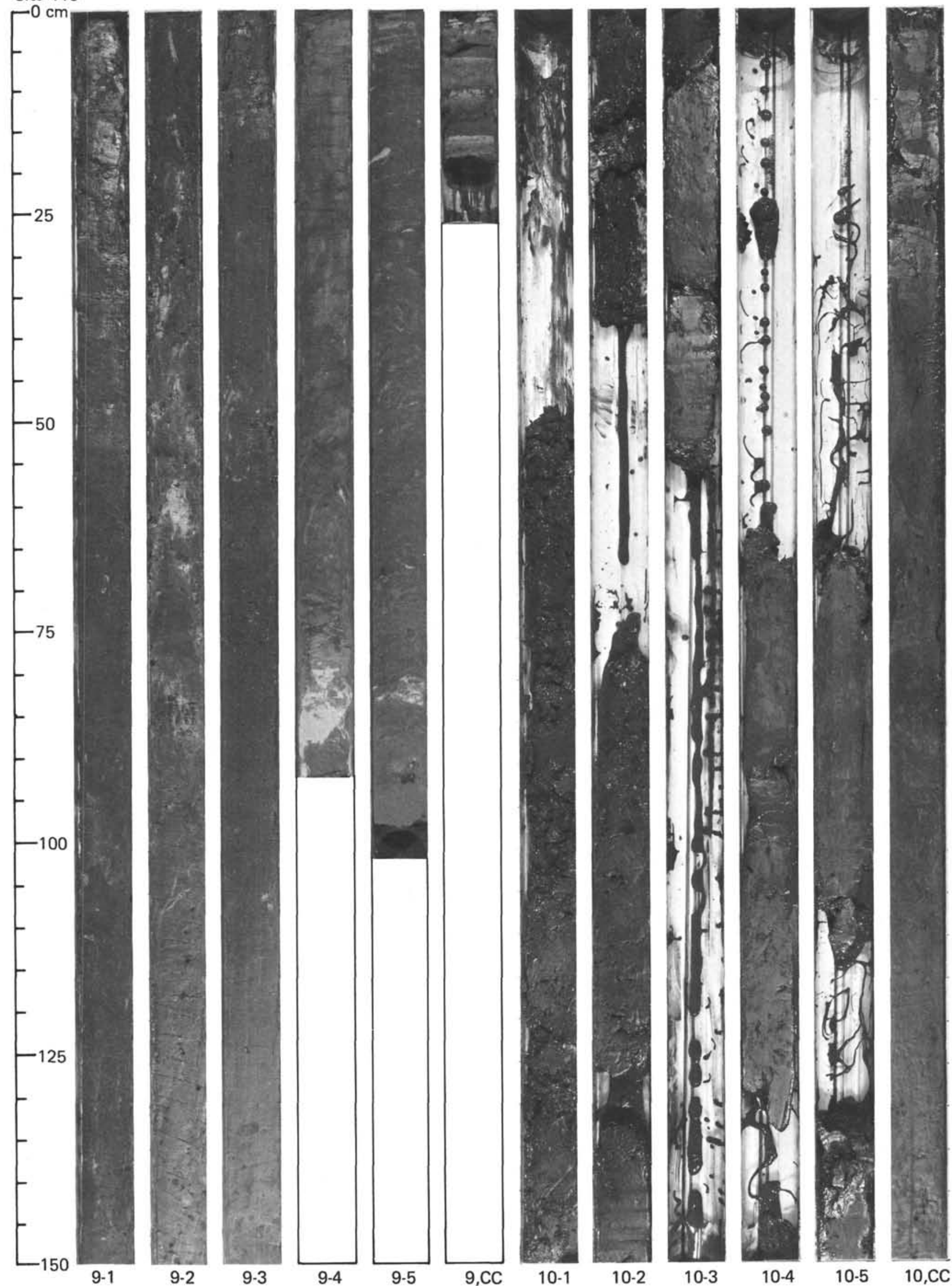




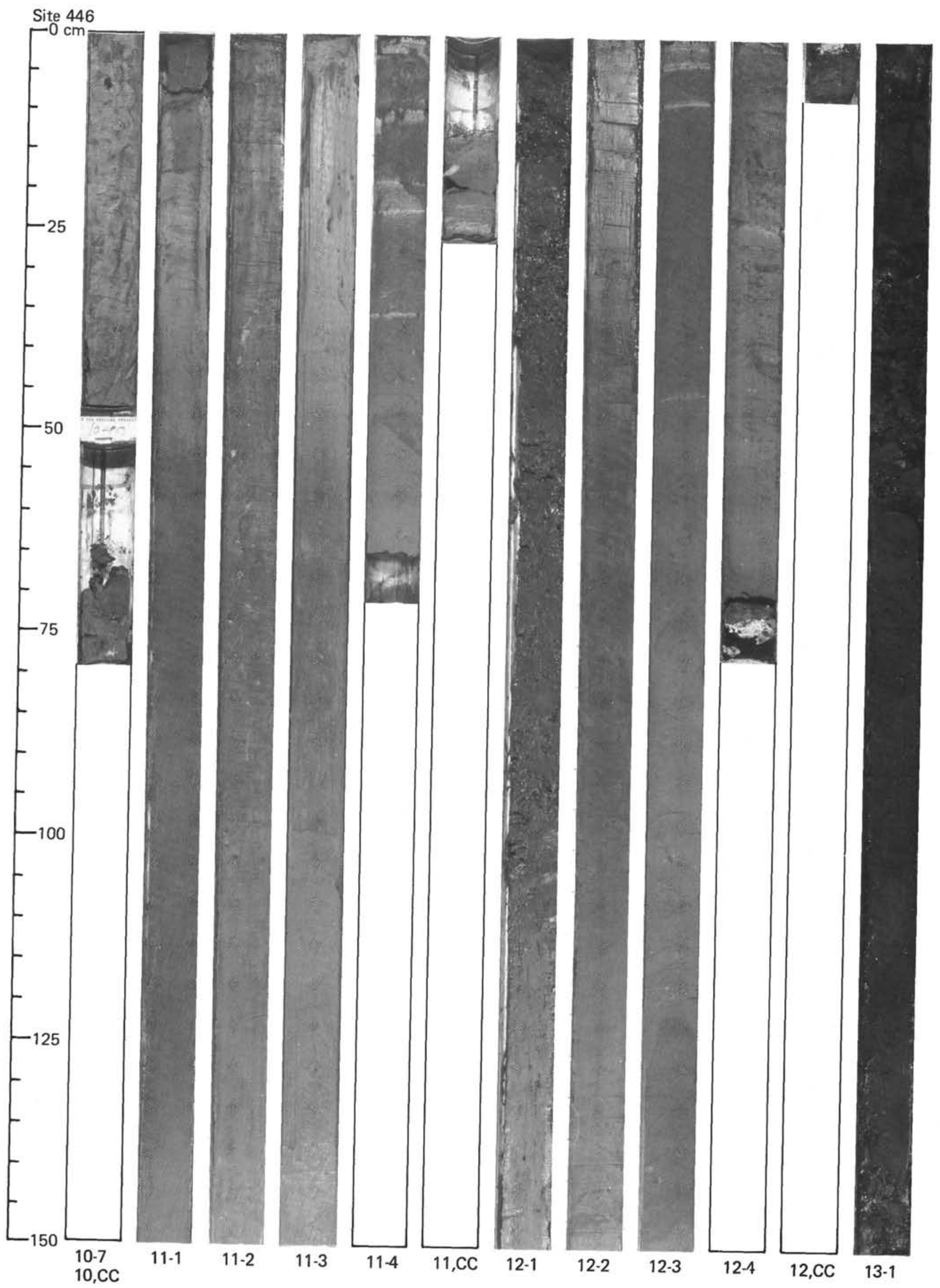




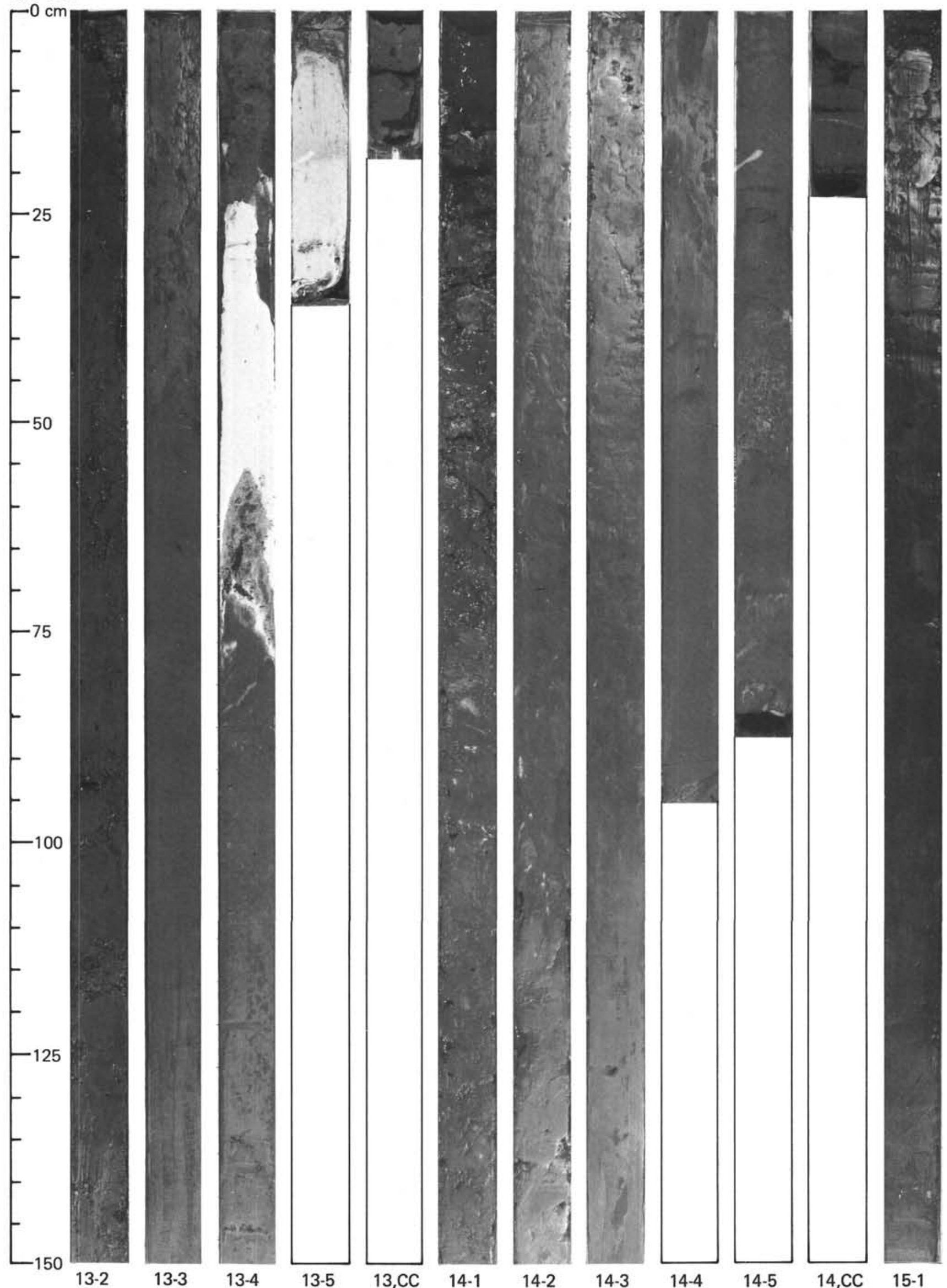




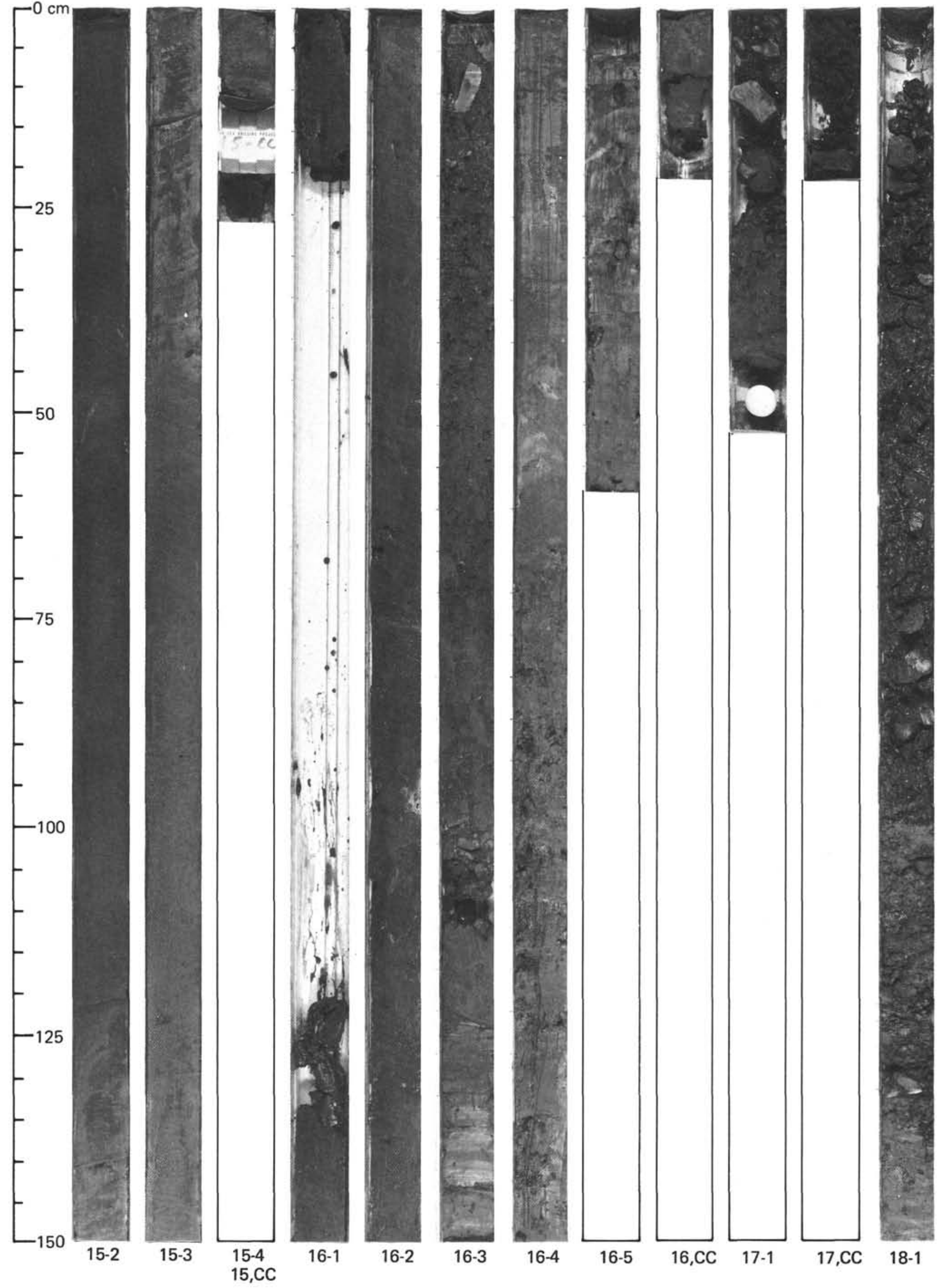


Site 446

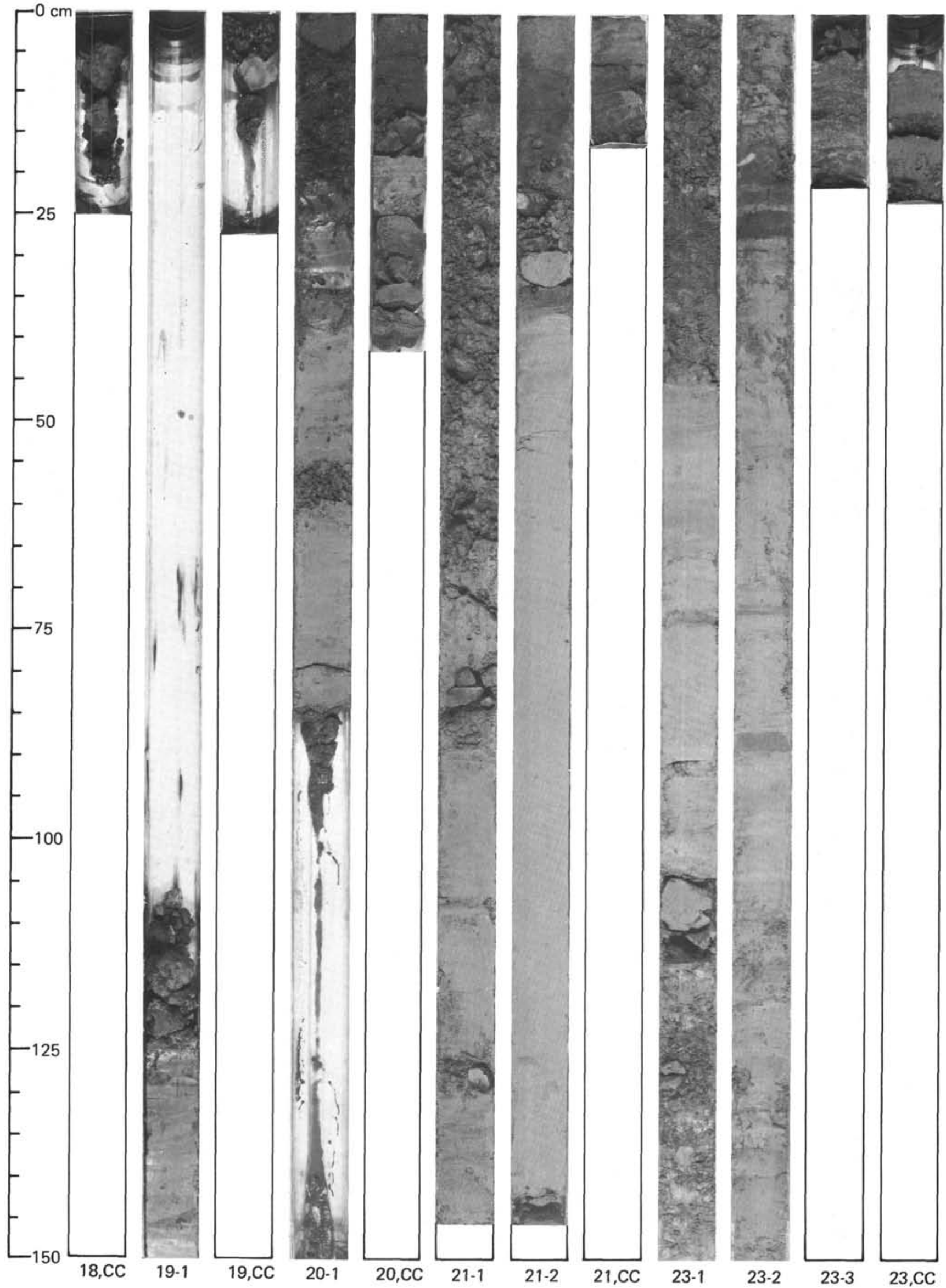




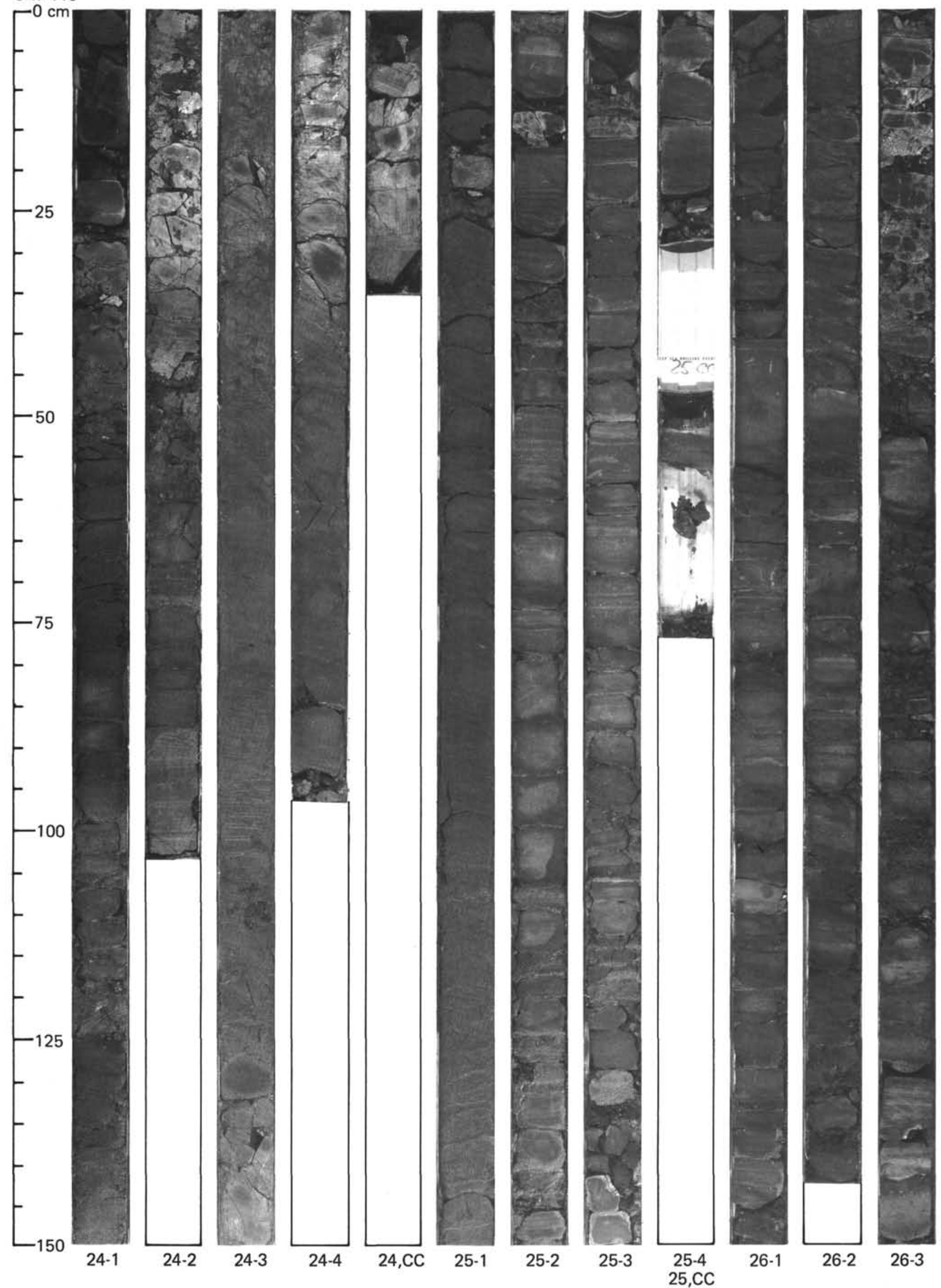




\section{Site 446}

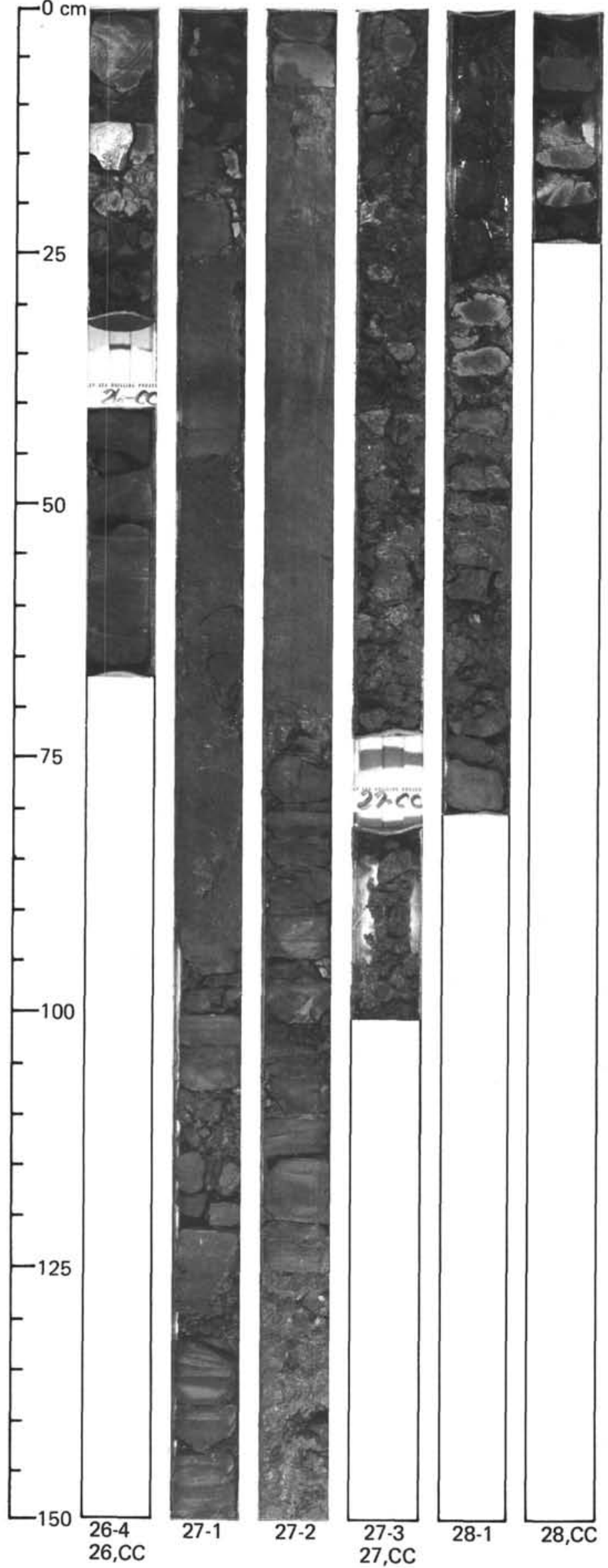

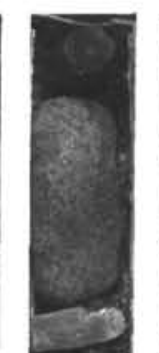
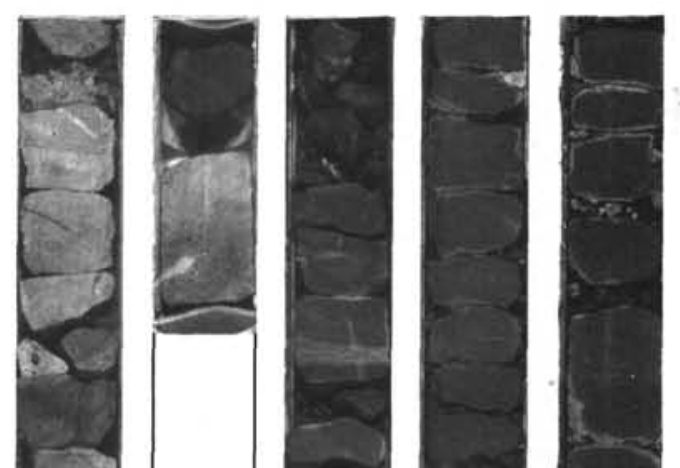

5
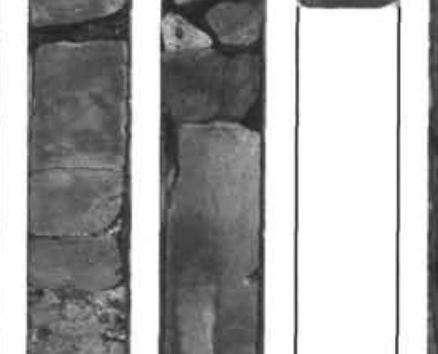

5.

-4
-9
-8

$5+19$

20
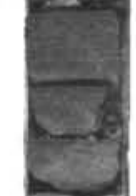

and

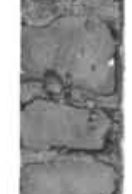

$=$

Dosed

$8 x$

pors

$\longrightarrow$

$5 \times$

$\frac{3}{43}$

5
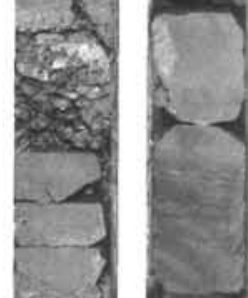

(2)

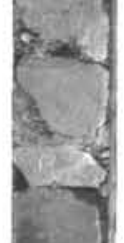

29-1

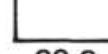

29-2

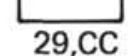

30-1

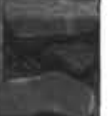$$
4
$$ 


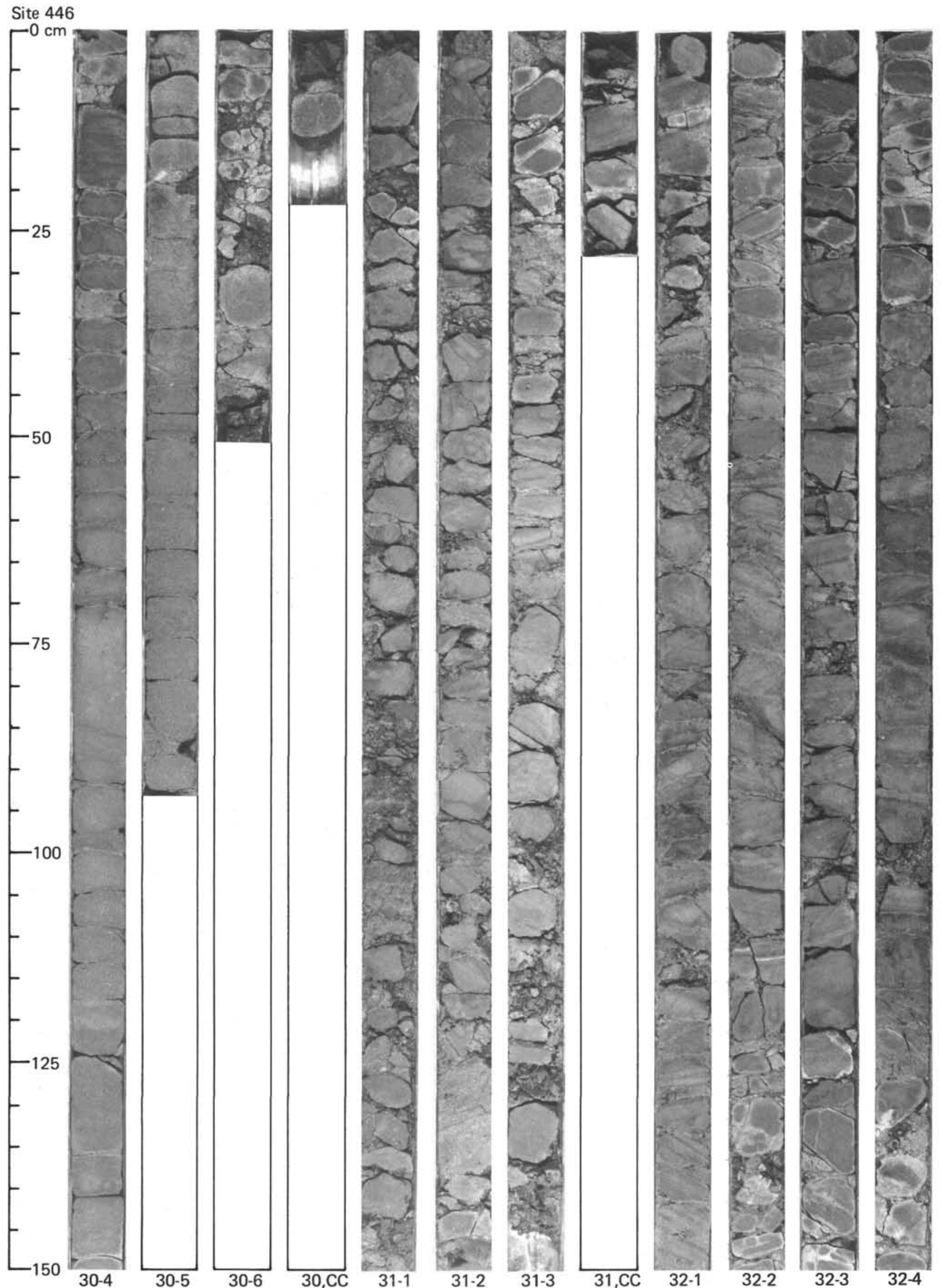




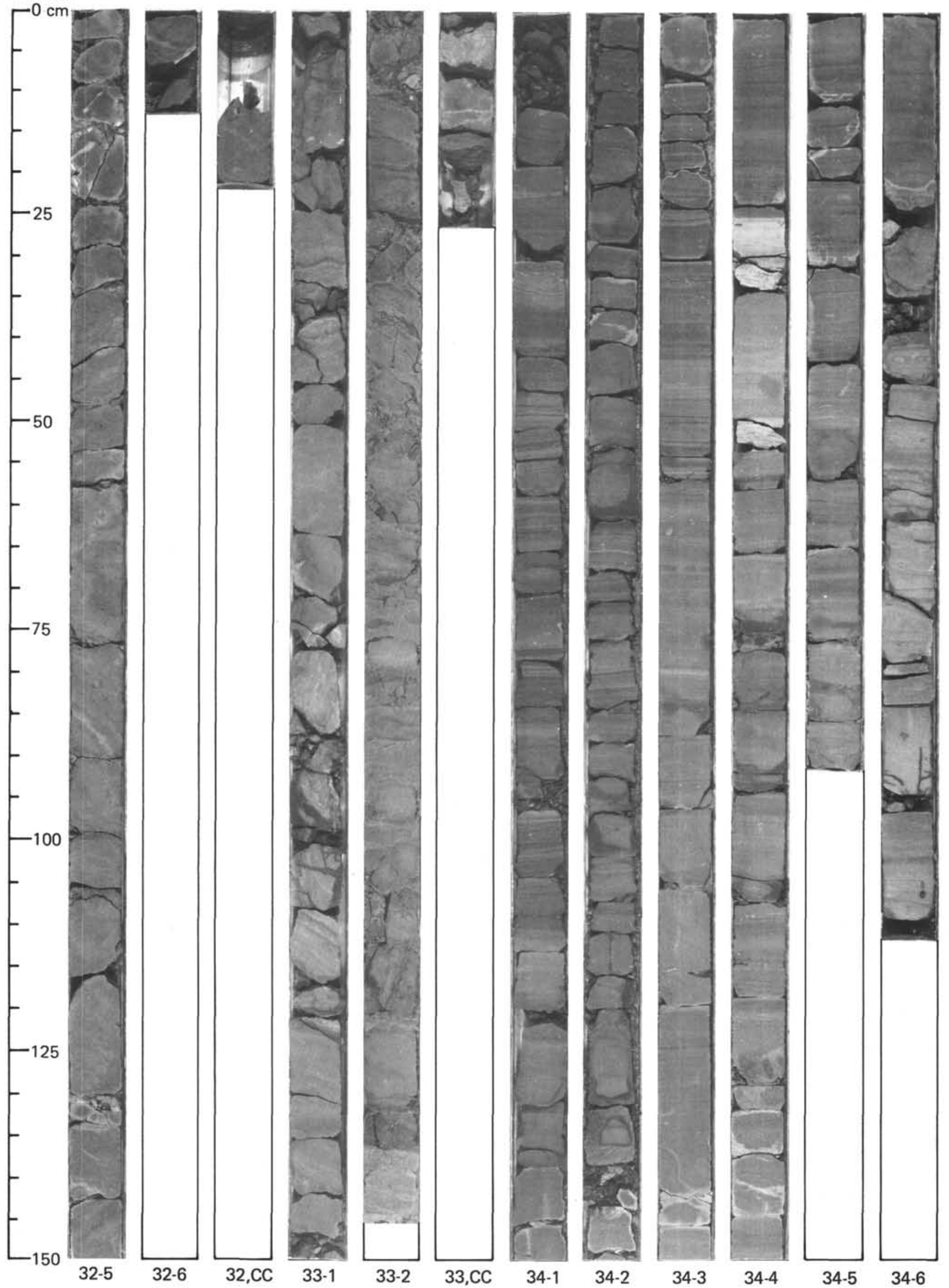


Site 446

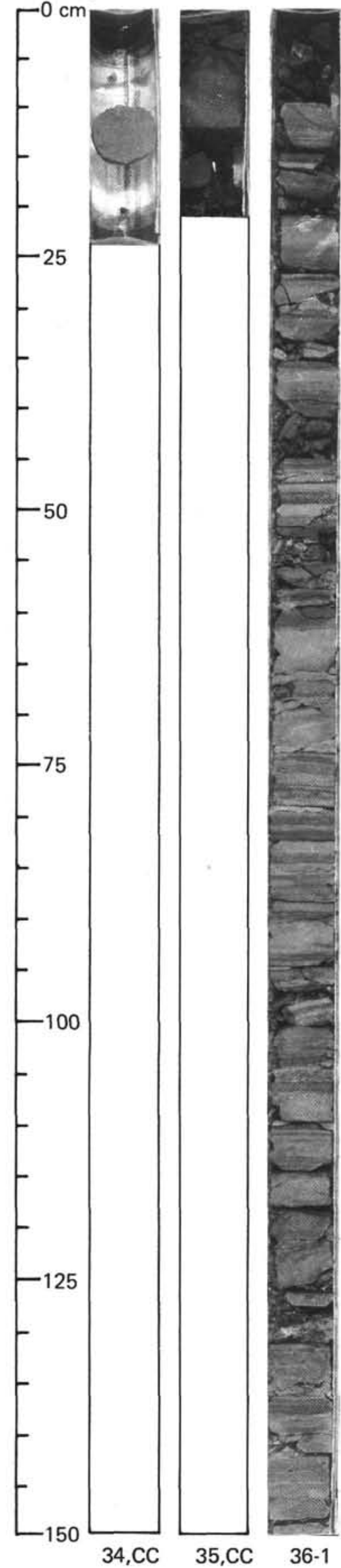

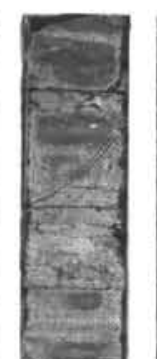
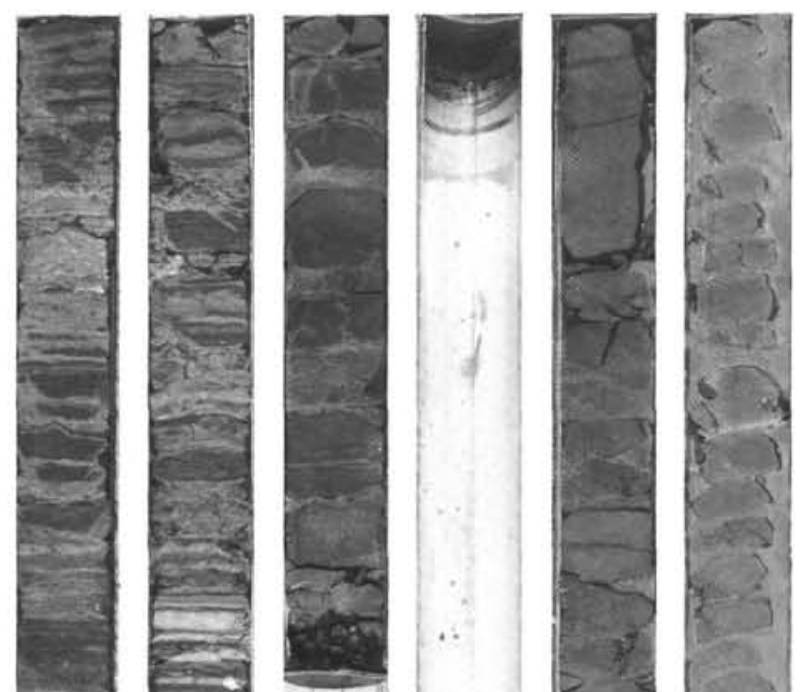

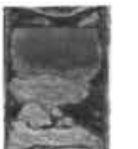
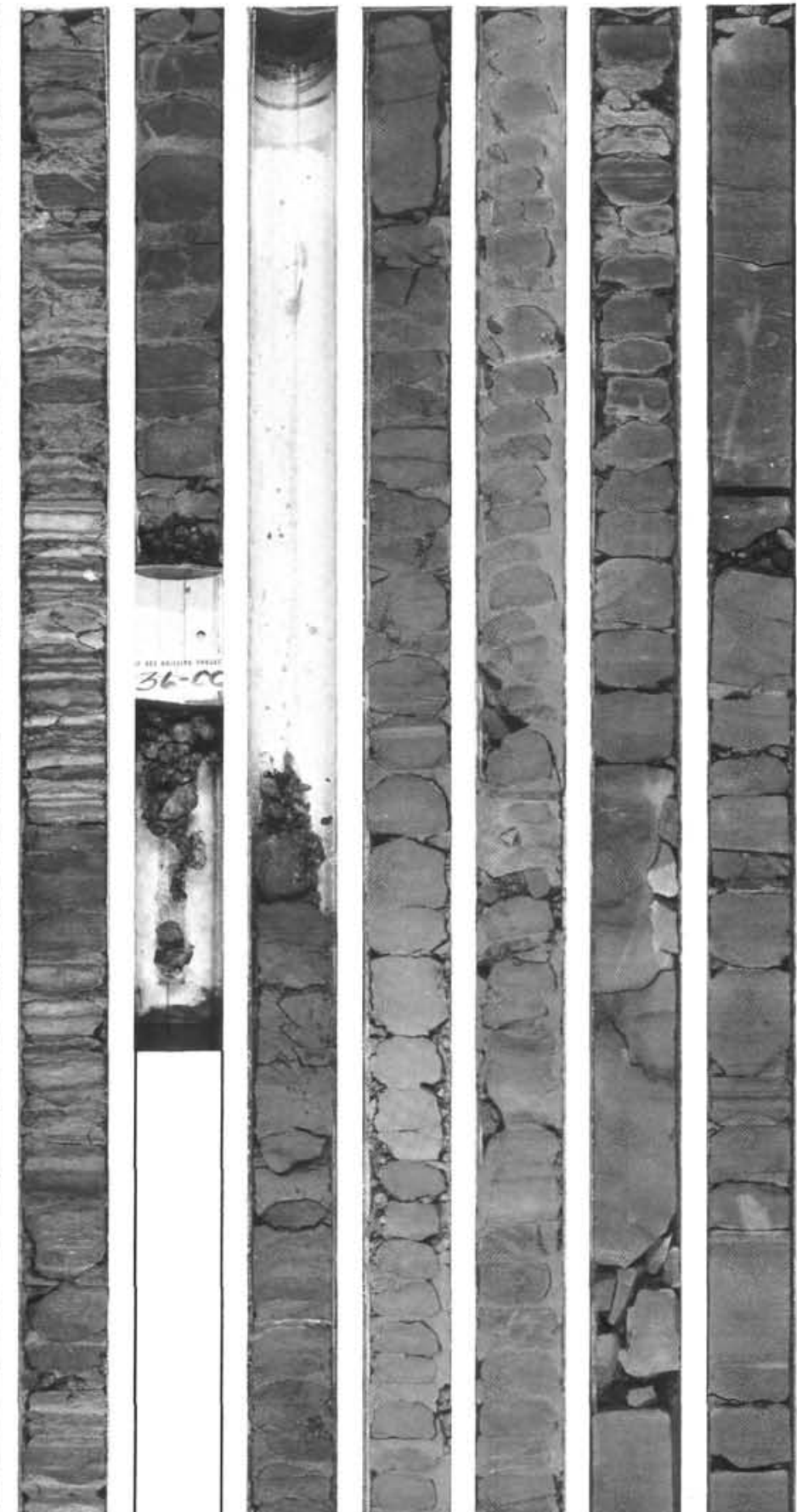

$1=0$
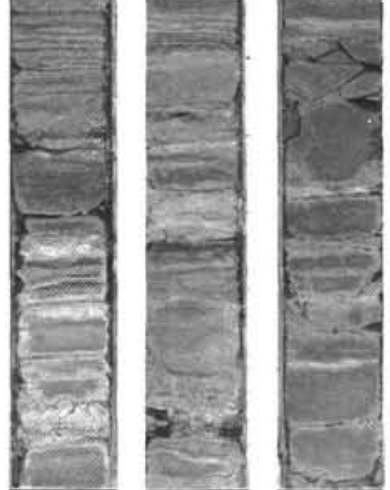

36-4

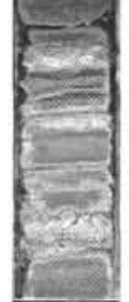

$36-2$
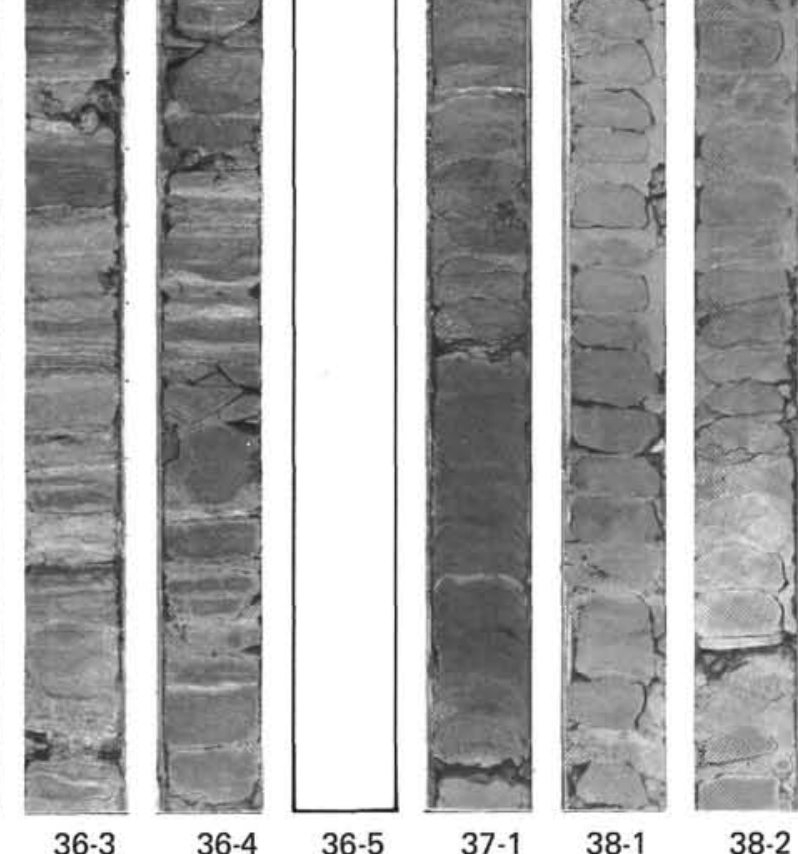

36-5

37-1

38-1

38-2

38-3
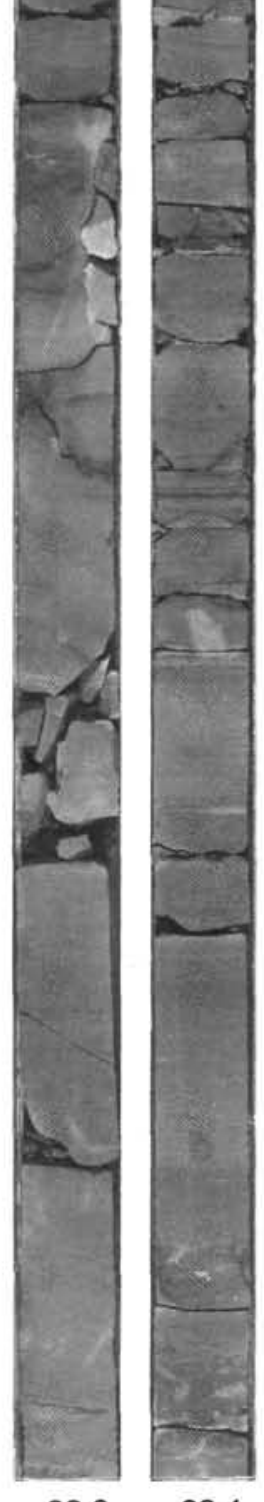
Site 446

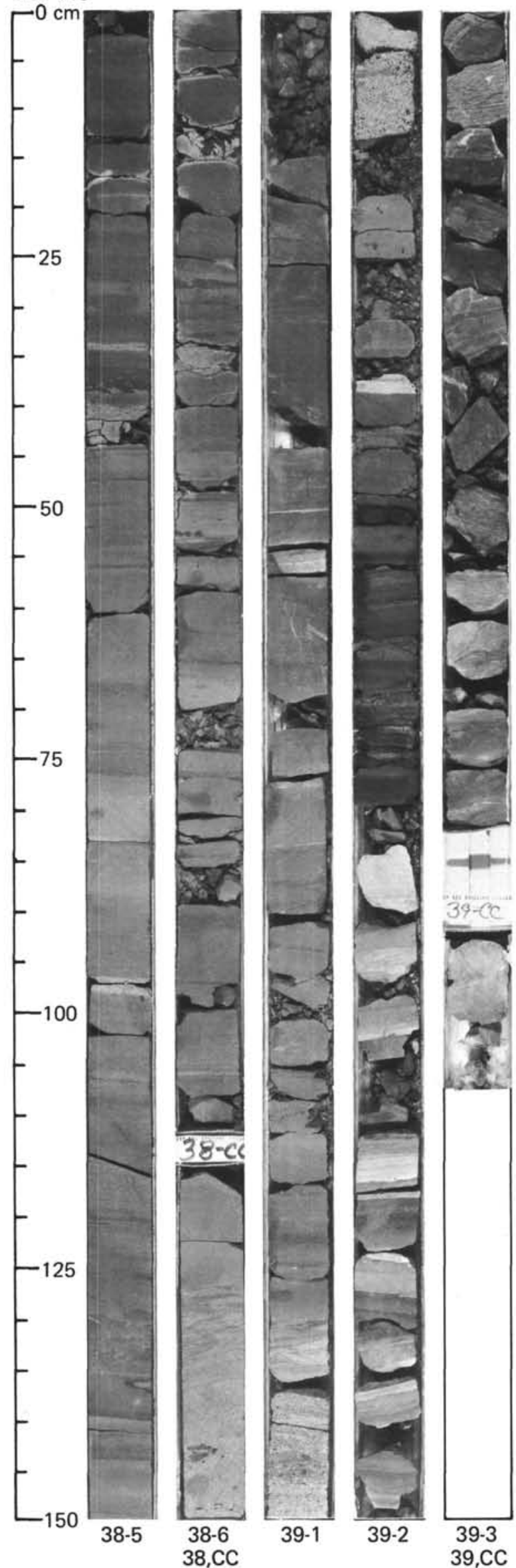

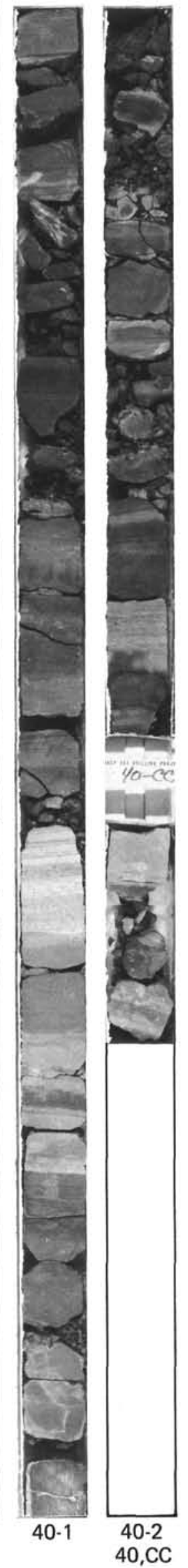
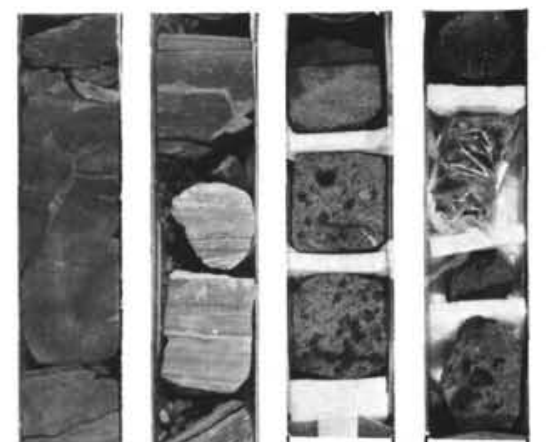

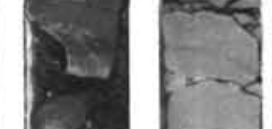

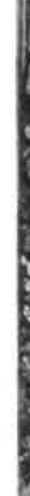
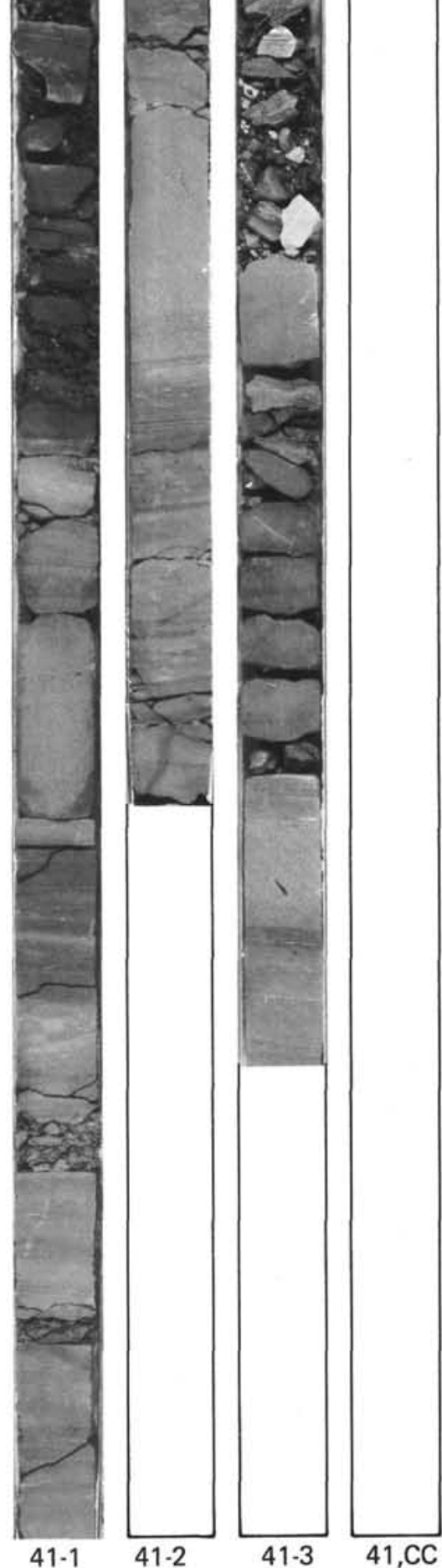

$42 \mathrm{CC}$ 


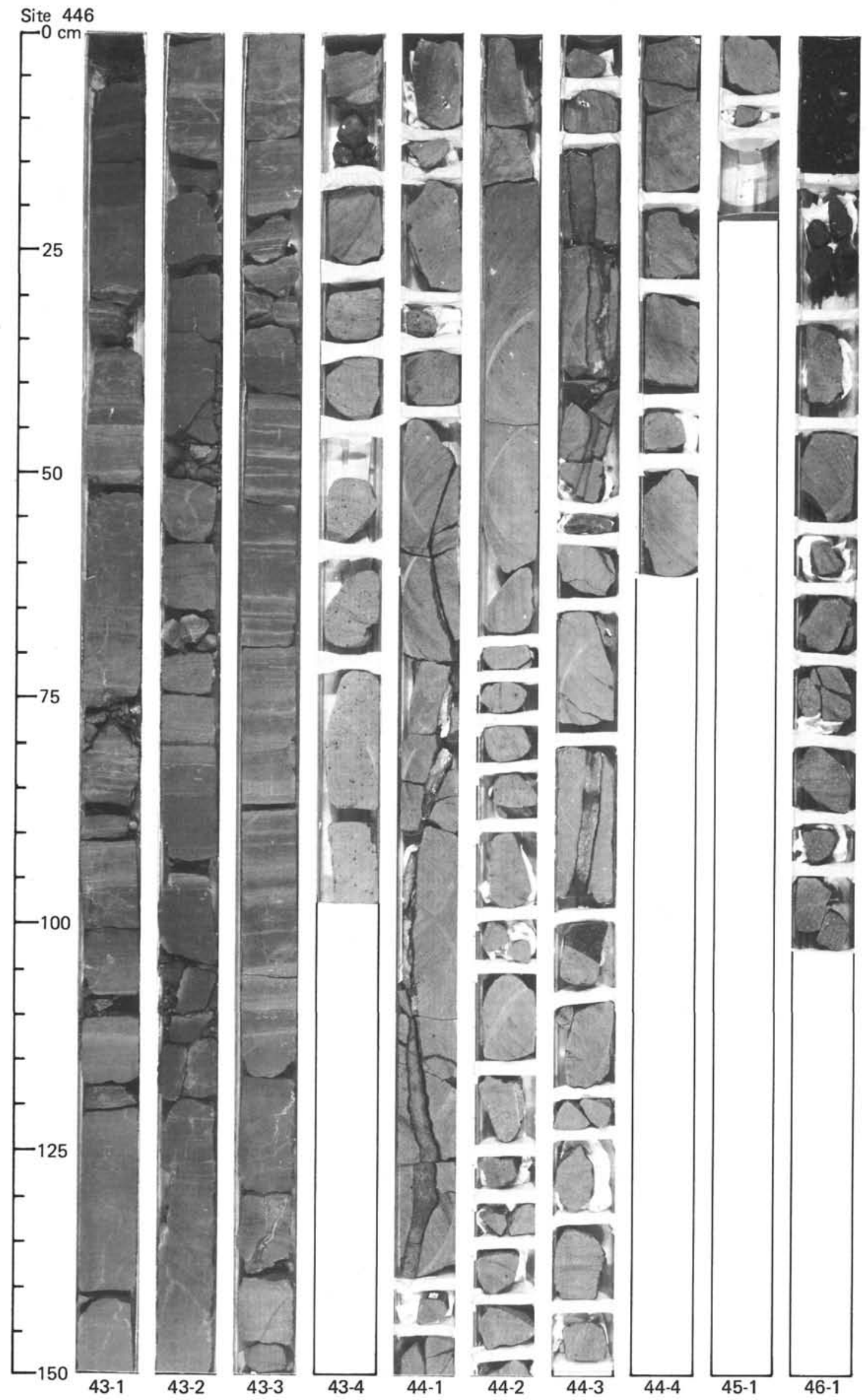




\section{Hole 446A}

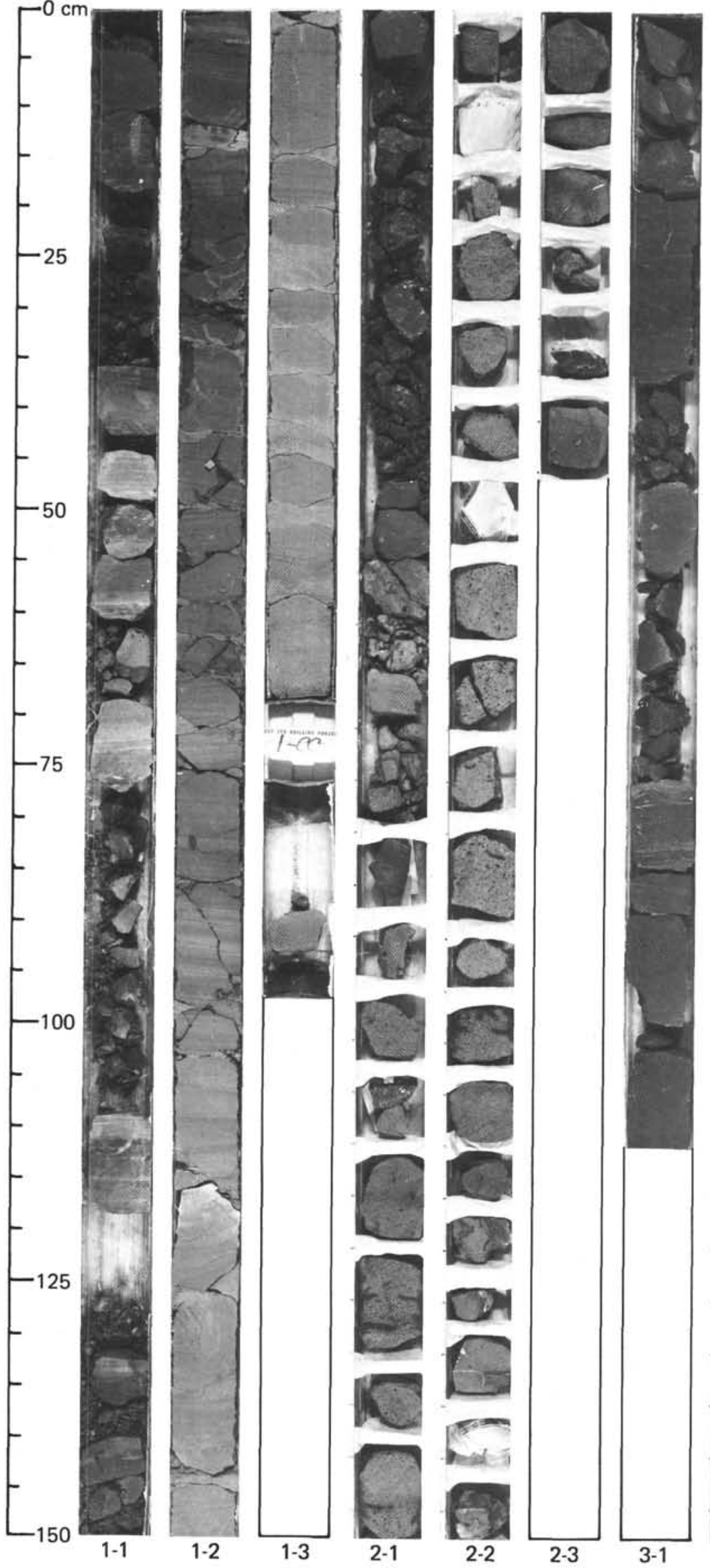

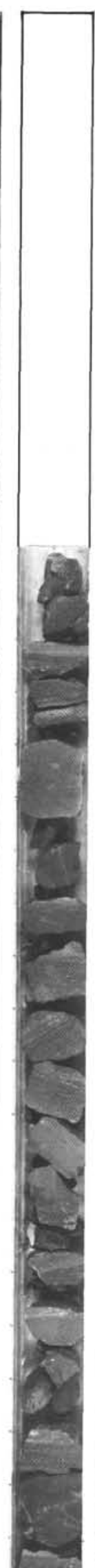

3-2
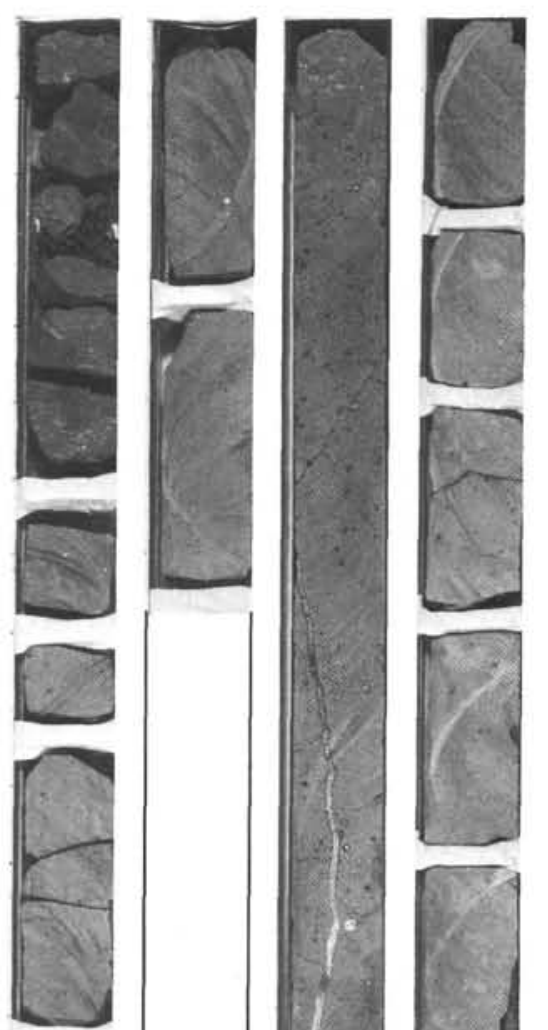

It
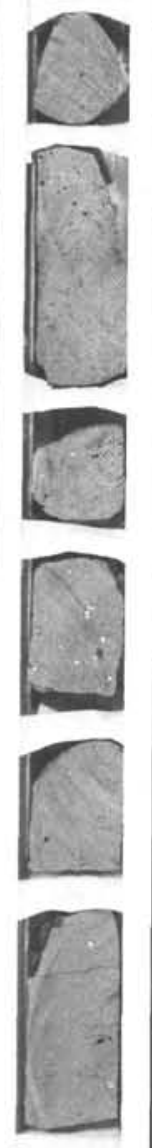

3-3
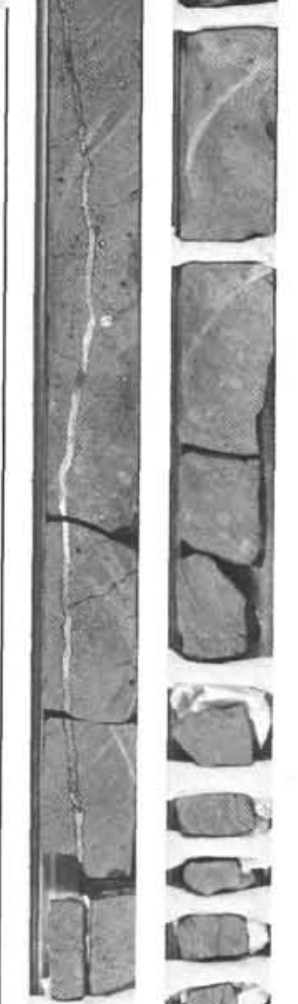

Q

$\square$

C. 1.

21

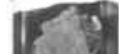

ID
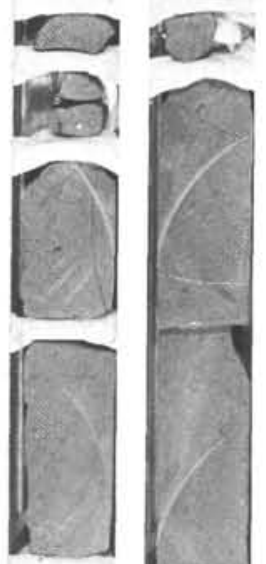

4-1

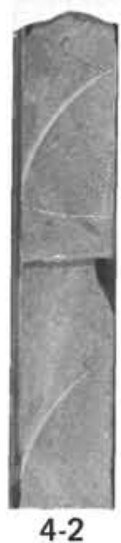


Hole 446A

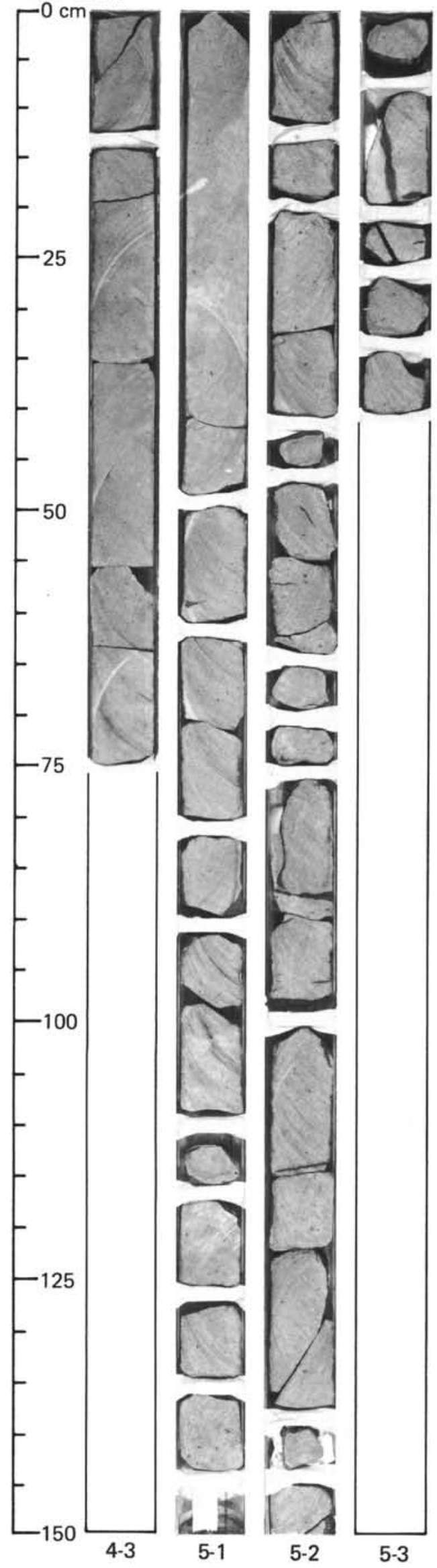

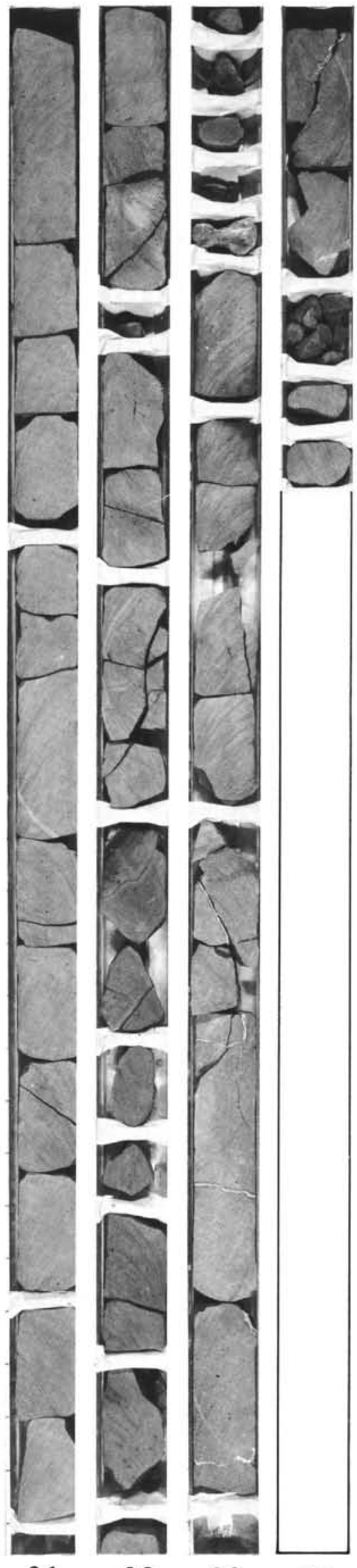

6-3

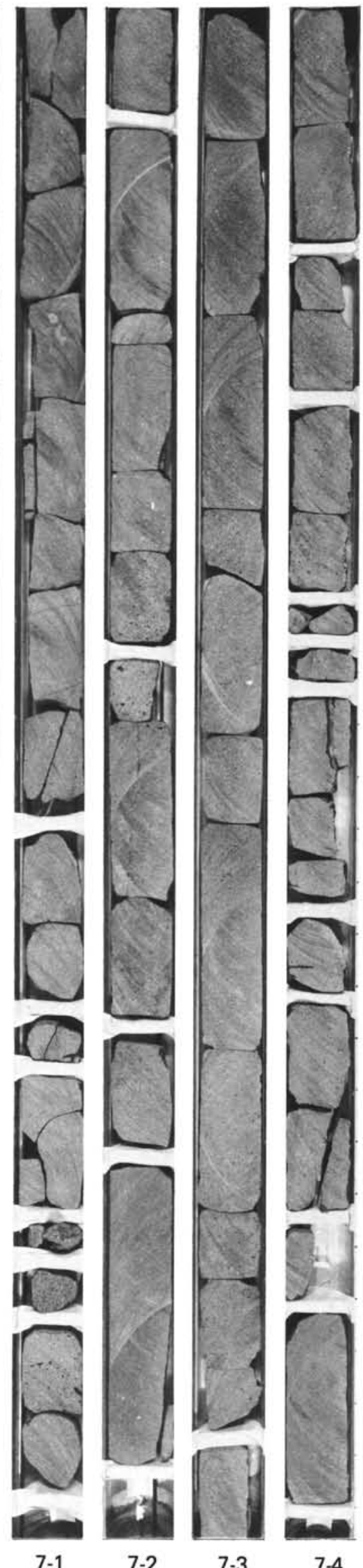




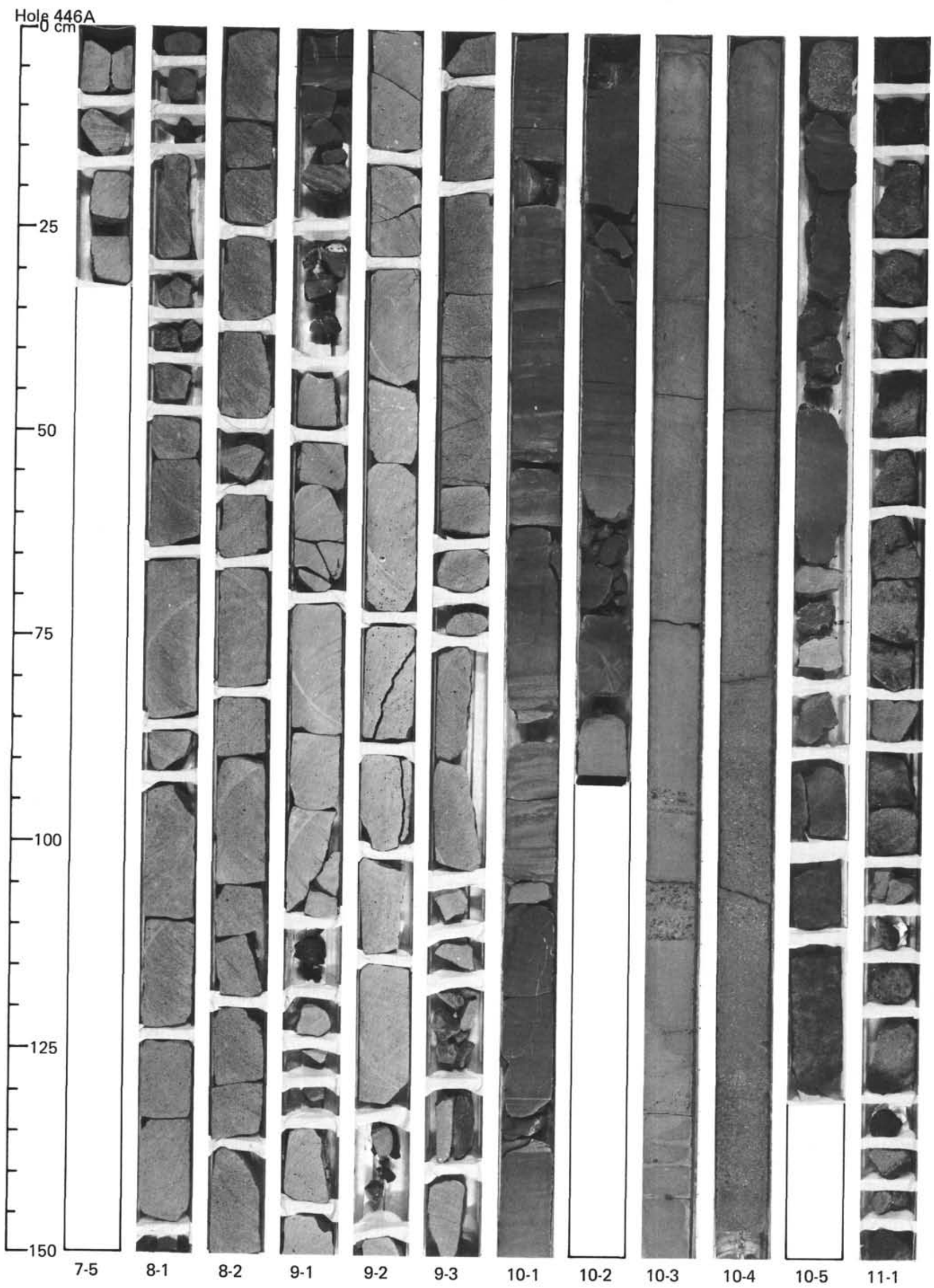


Hole 446A

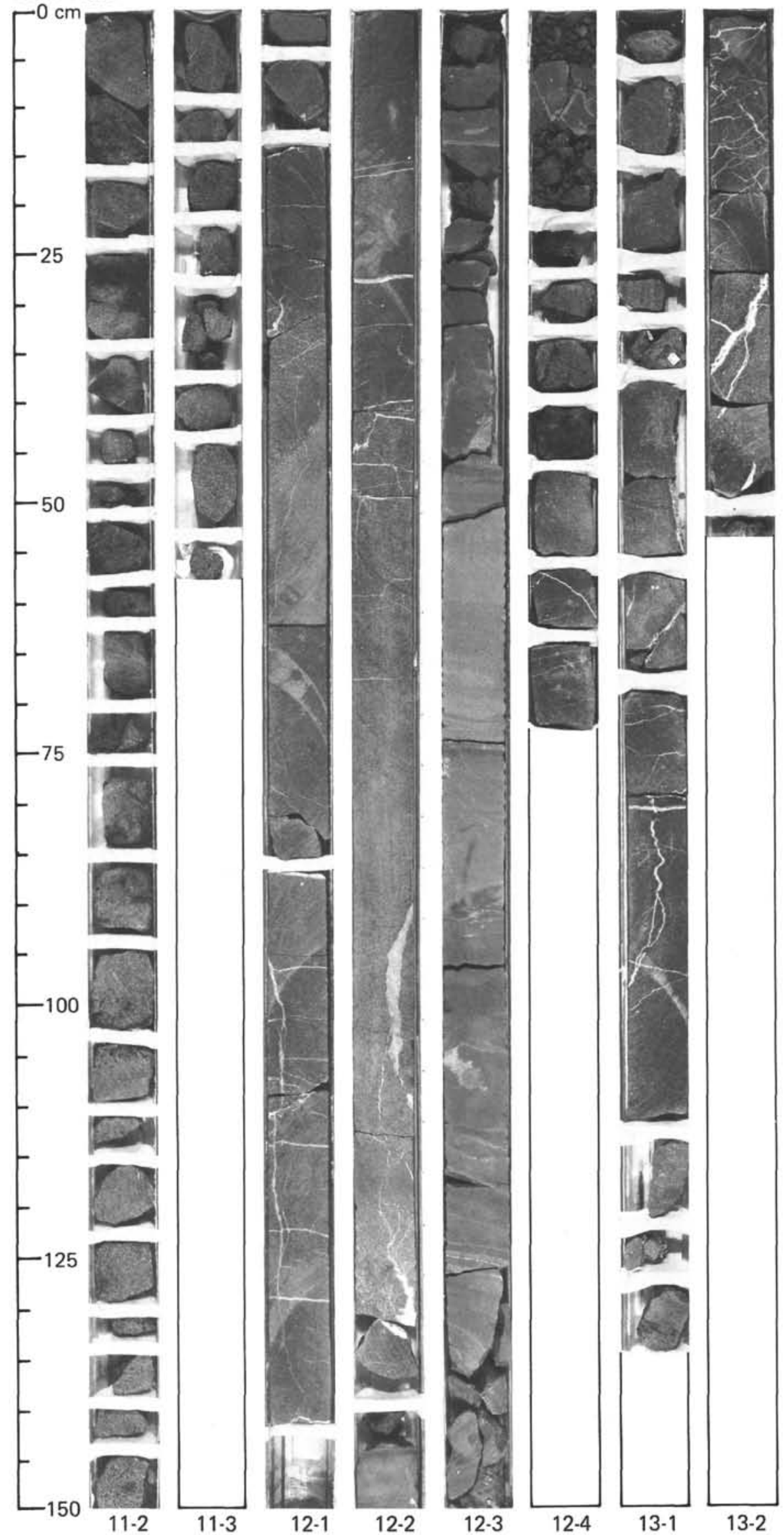

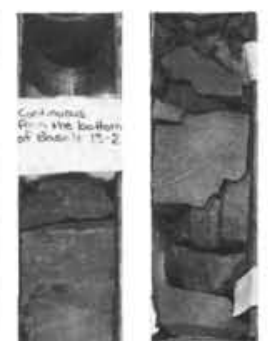
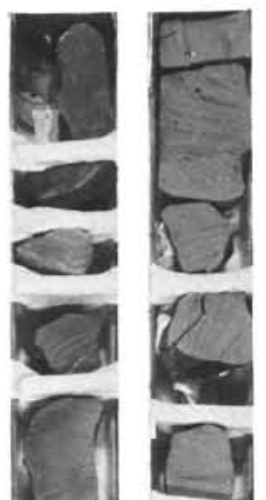

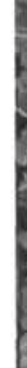
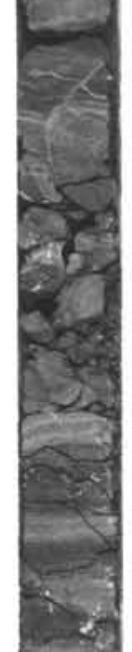

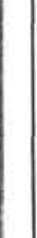

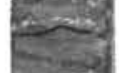

$2-3$

axis

30
3
3

$5-3$

$x+y$
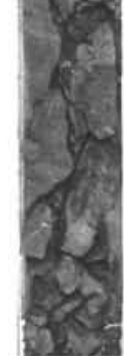

13-3
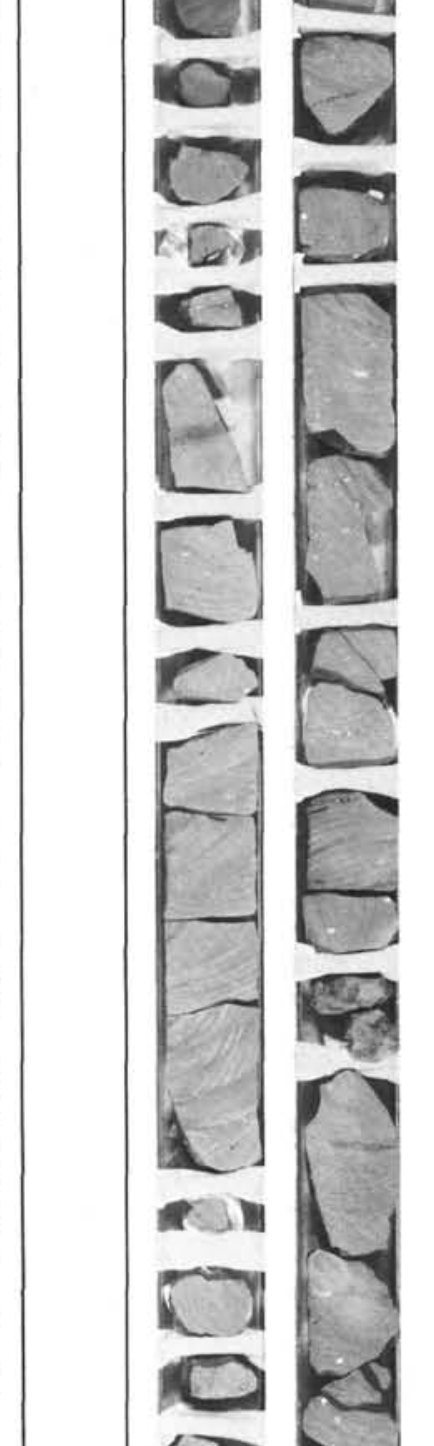

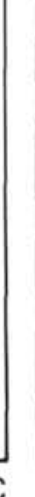

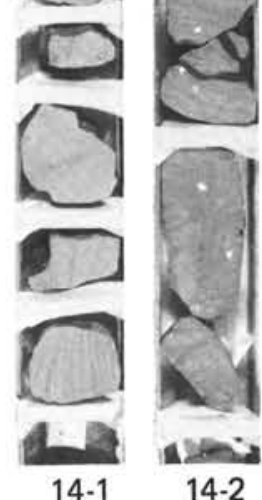


Hole 446A

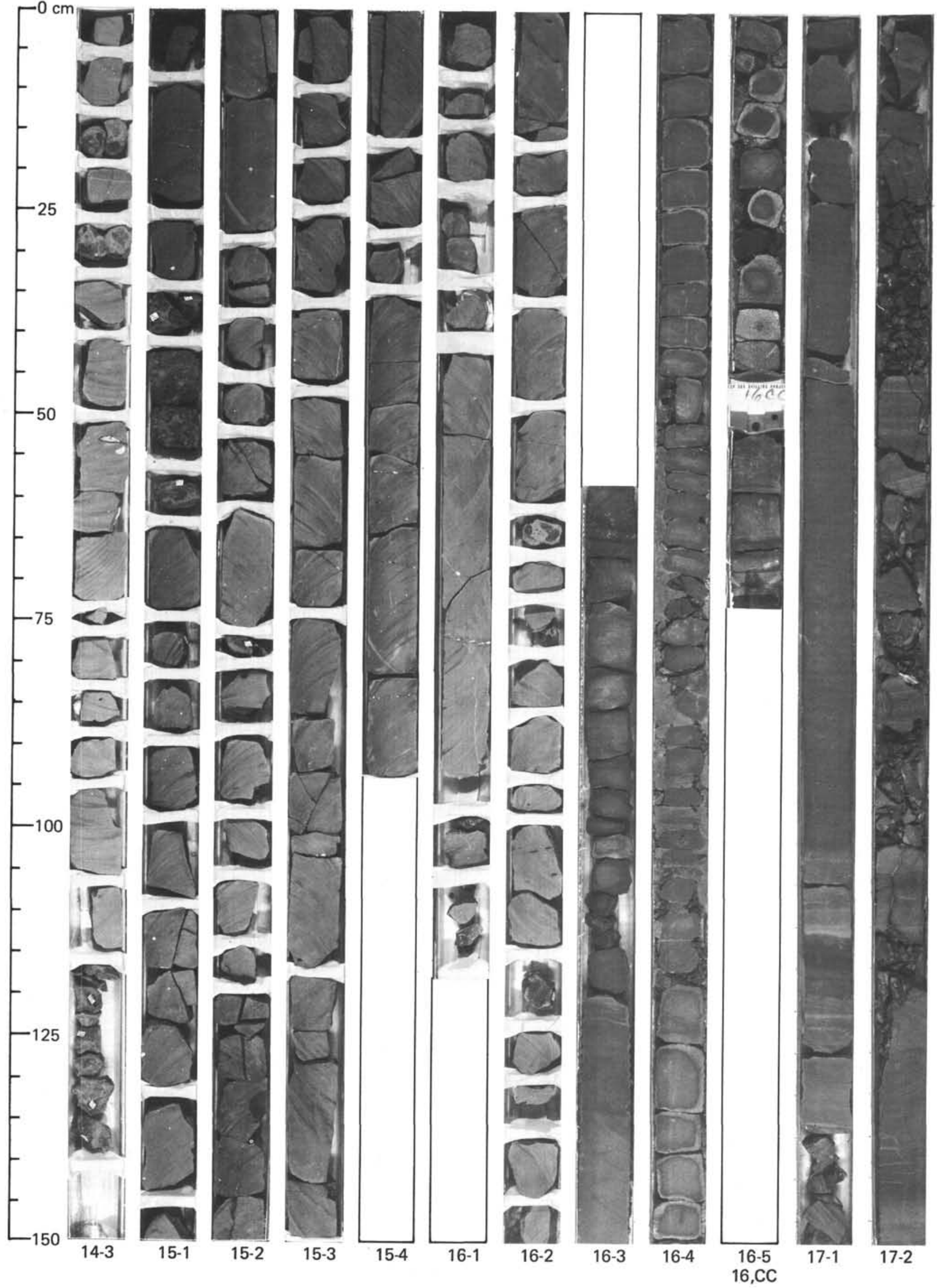


Hole 446A

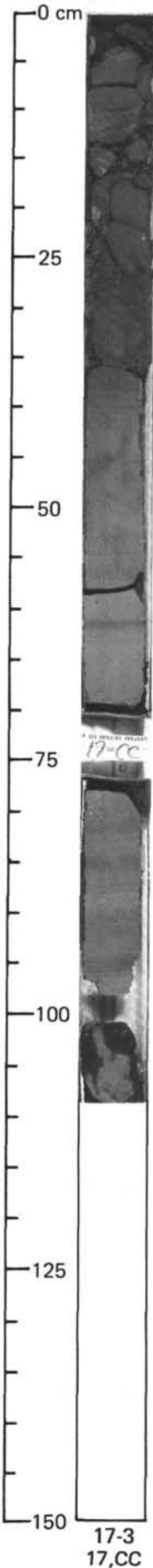

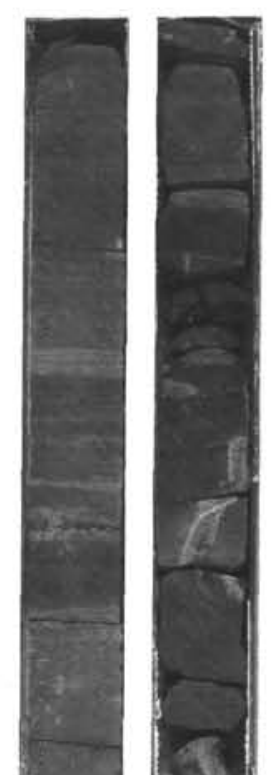
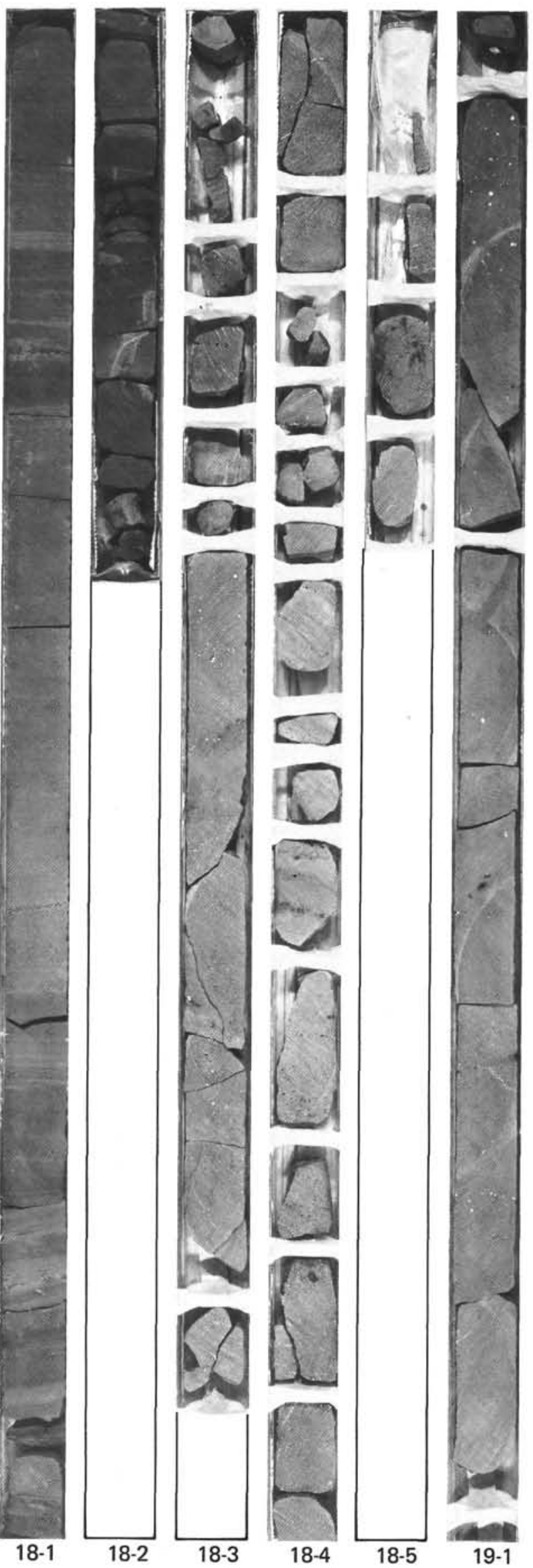
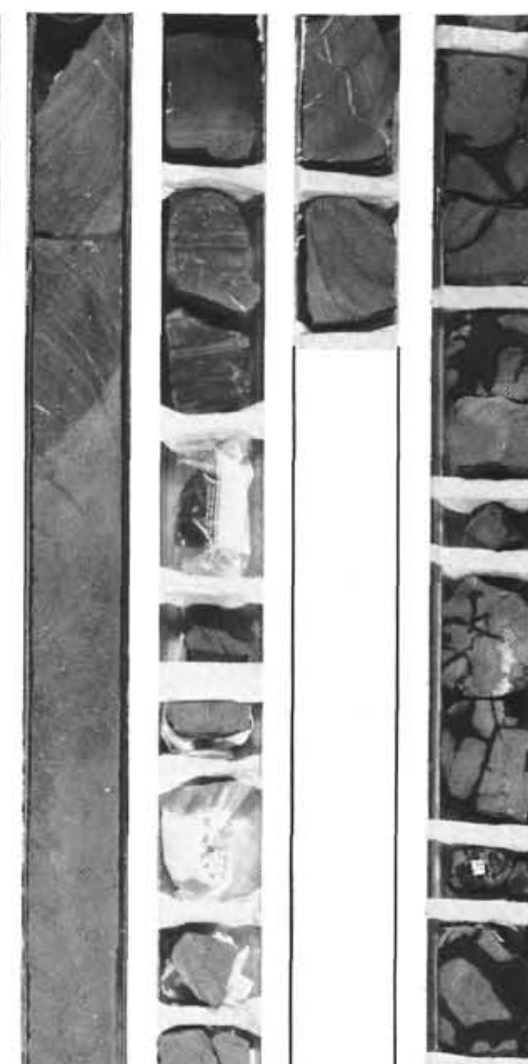
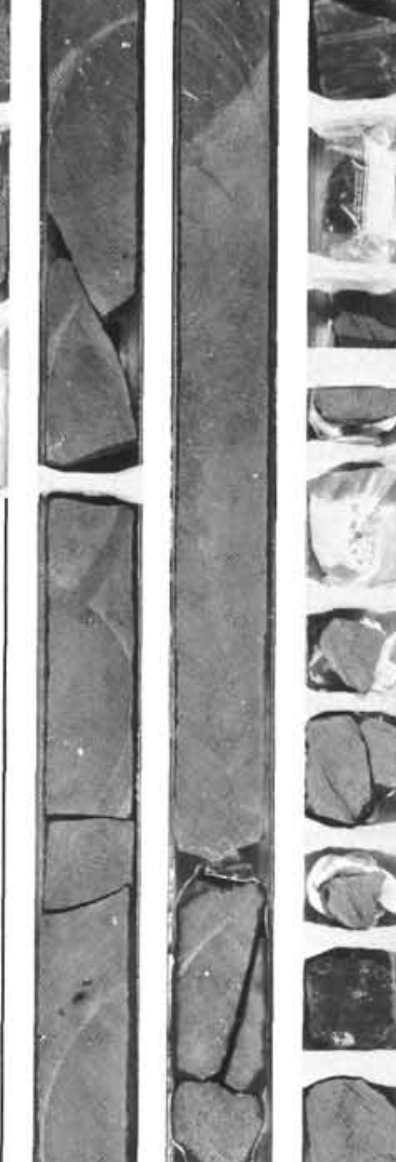

\section{.}
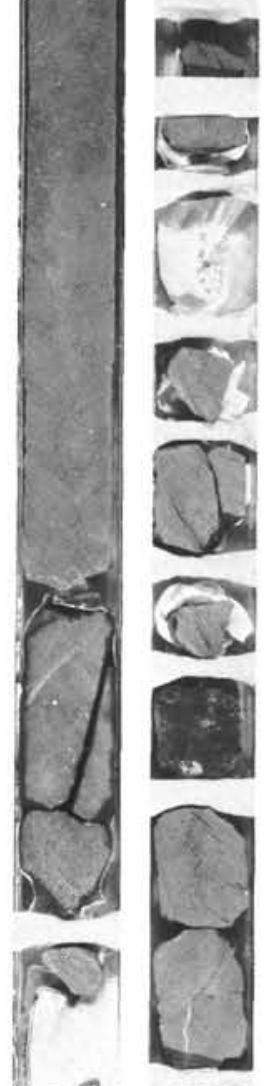

1
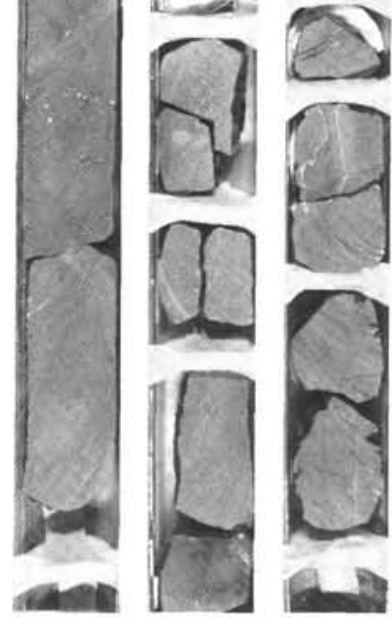

18-5

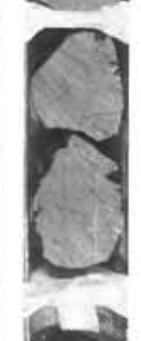

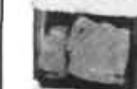

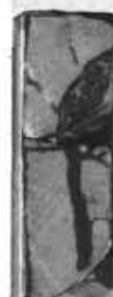

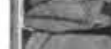
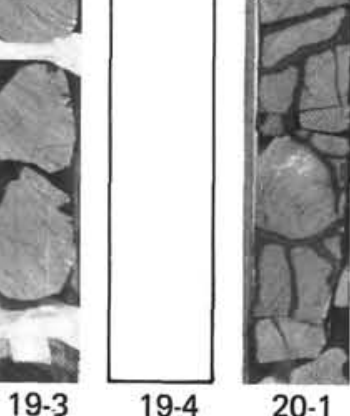

20-1
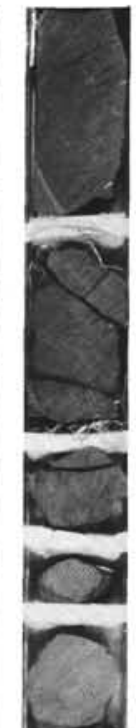

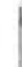
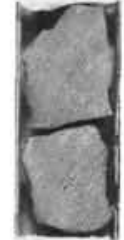

.
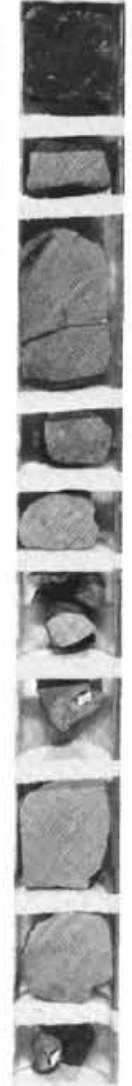

20-2 
Hole 446A

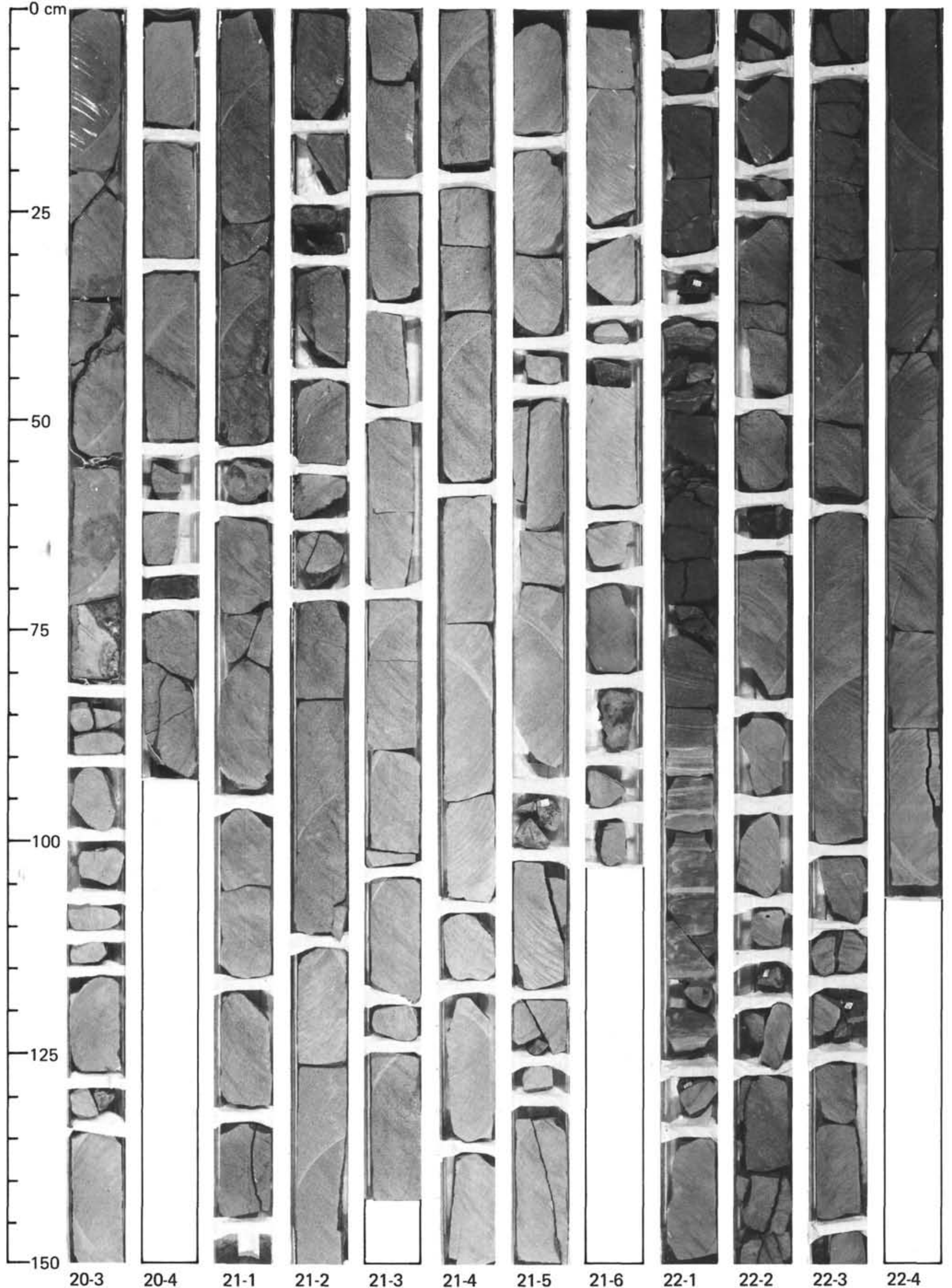


Hole 446A

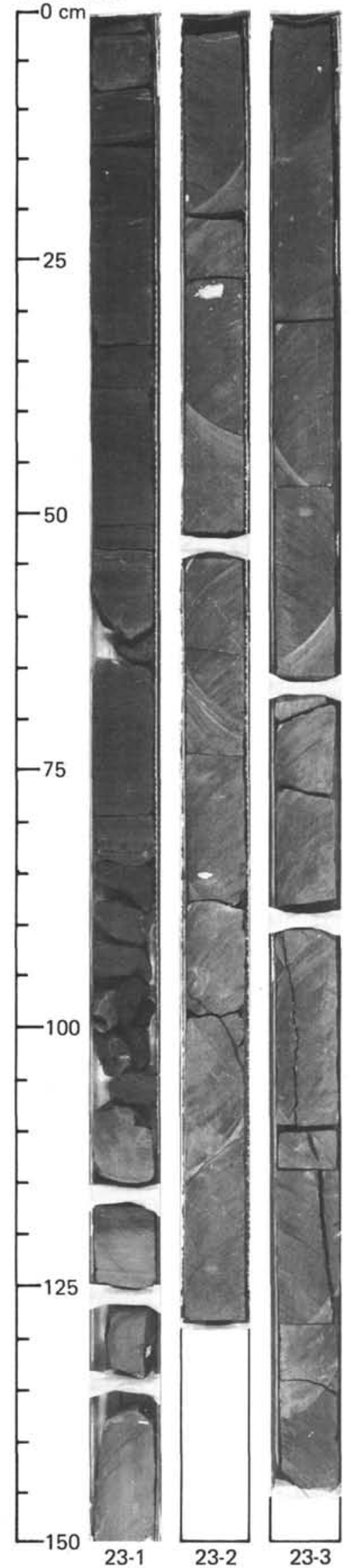

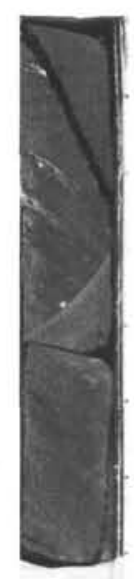
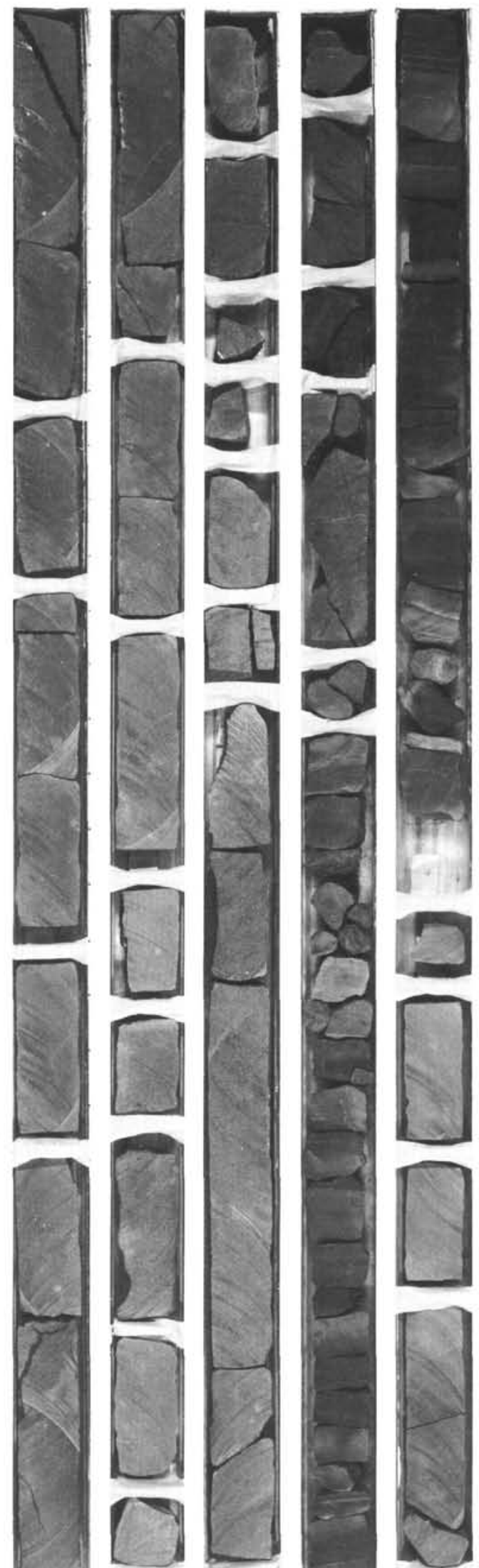

$\frac{}{23-4}$
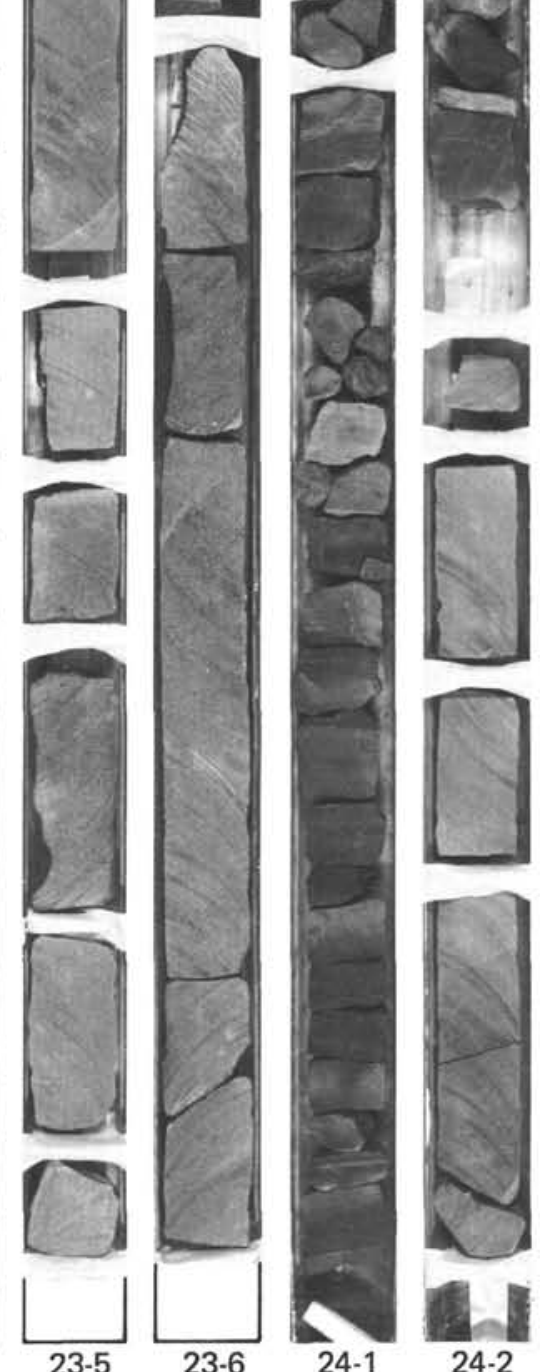
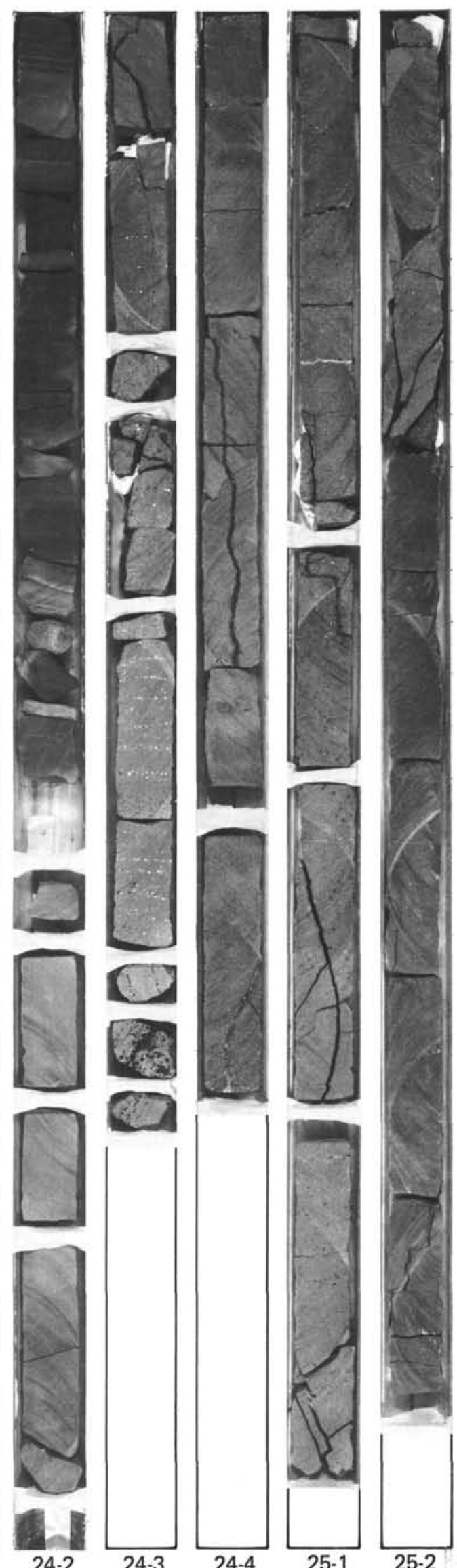
Hole 446A

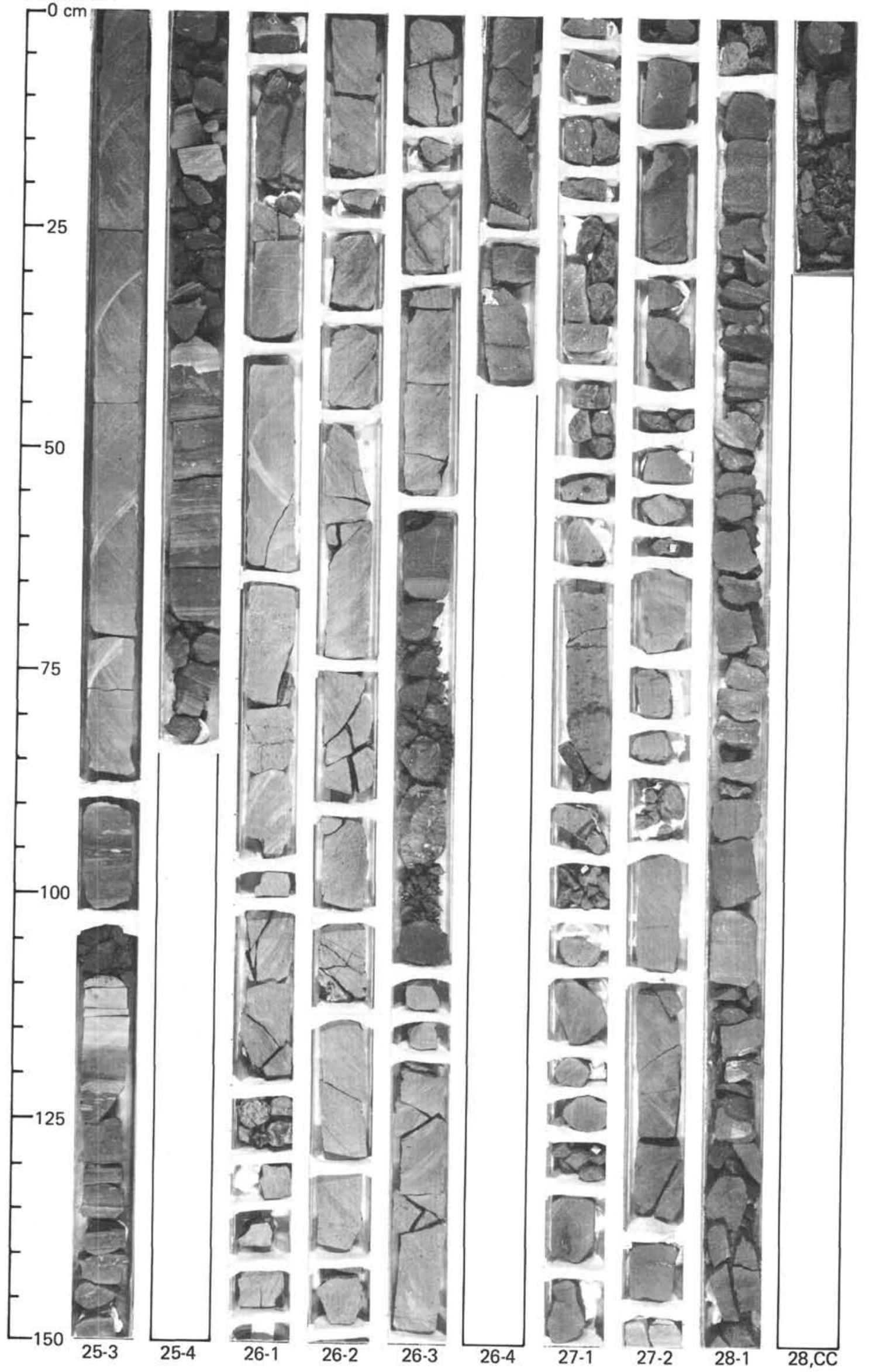

